\title{
Diverse Aromatic Metabolites in the Solitary Tunicate Cnemidocarpa irene
}

\author{
Kei Miyako $^{\dagger}$, Yoko Yasuno ${ }^{\ddagger}, \S$, Tetsuro Shinada ${ }^{\ddagger}$, Masaki. J Fujita ${ }^{\dagger}$ and Ryuichi Sakai ${ }^{*}{ }^{\dagger}$ \\ ${ }^{\dagger}$ Faculty and Graduate School of Fisheries Sciences, Hokkaido University, 3-1-1 minatocho, Hakodate, Hokkaido \\ 041-8611, Japan \\ Graduate School of Science, Osaka City University, 3-3-138, Sugimoto, Sumiyoshi, Osaka 558-8585, Japan
}

\section{Table of contents}

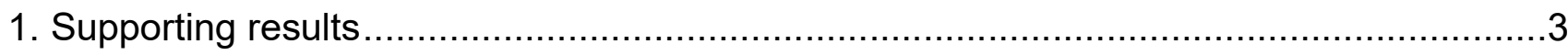

1.1. An HPLC chromatogram of an aromatic rich fraction of $C$. irene. ............................

Figure S1. An HPLC-PDA chromatogram of an aromatic rich fraction. ....................................................... 3

1.2. Physicochemical properties of authentic 6-biopterin $\mathrm{HCl}$ salt and characterization of

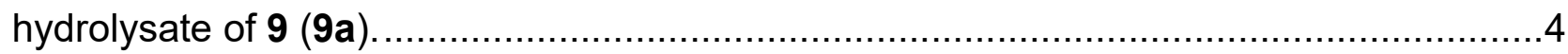

Figure S2. HPLC chromatograms of (A) 9 and (B) partially hydrolyzed 9............................................ 4

Figure S3. Extracted ion chromatograms of (A) authentic 6-biopterin and (B) 9a......................................... 5

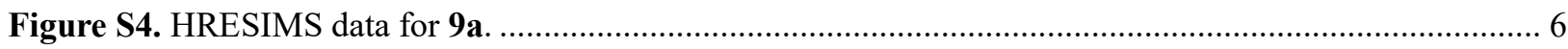

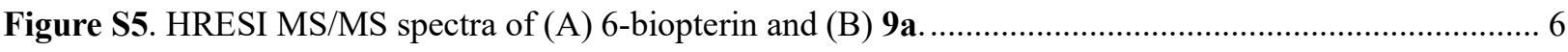

Figure S6. ${ }^{1} \mathrm{H}$ NMR spectra of authentic (A) 6-biopterin $\mathrm{HCl}$ salt and (B) 9a in DMSO-d $d_{6}(400 \mathrm{MHz}) \ldots \ldots \ldots . .7$

Figure S7. ECD spectra of authentic 6-biopterin and 9a............................................................................ 7

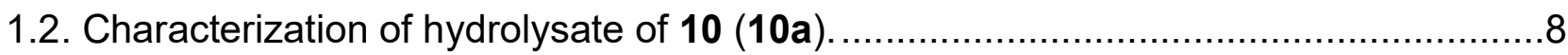

Figure S8. HPLC chromatograms of (A) 10 and (B) partially hydrolyzed 10 ............................................ 8

Figure S9. Extracted ion chromatograms of $(\mathrm{A})$ authentic 6-biopterin and (B) 10a...................................... 8

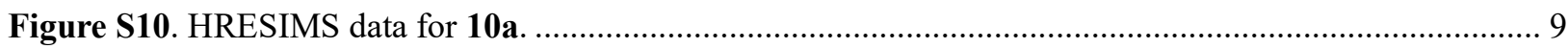

Figure S11. HRESI MS/MS spectra of (A) authentic 6-biopterin and (B) 10a.......................................... 9

Figure S12. ${ }^{1} \mathrm{H}$ NMR spectra authentic of (A) authentic 6-biopterin $\mathrm{HCl}$ salt and (B) 10a in DMSO- $d_{6}$ (400 MHz)...

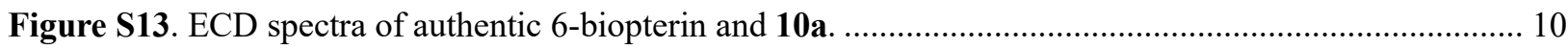

1.3. Absolute configuration assignment for acetate 12a. .................................... 11

Figure S14. Structures of (A) triacetate (12a), (B) 1,2-diacetyl-1-arylpropane (20) ${ }^{1}$ and (C) (1'R, 2' $\left.S\right)$-6-(1', 2'-

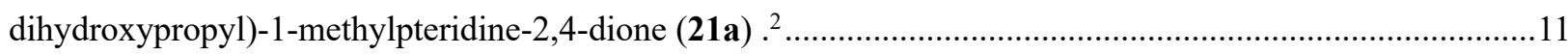

Table S1. ${ }^{1} \mathrm{H}$ NMR data comparison of 12a with 20 and 21 a...................................................................11

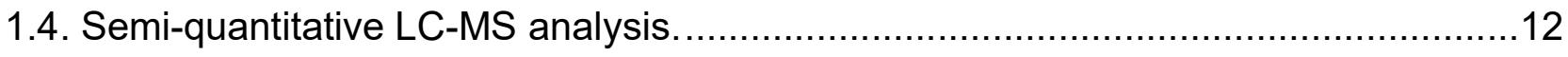

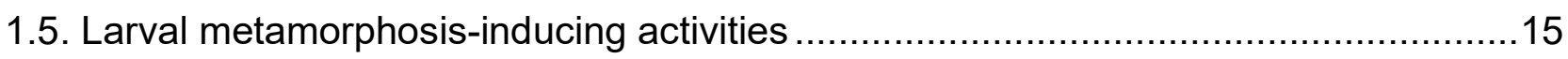

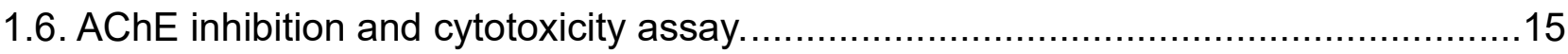

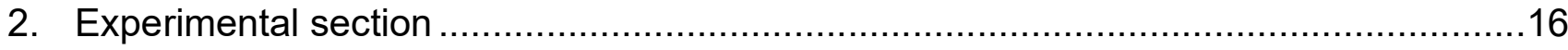

Figure S21. Separation schemes of compounds 6-7, 9, 11, 13-17. ......................................................... 16 
Figure S22. Separation scheme of compounds 8, 10, 12, 18-19.

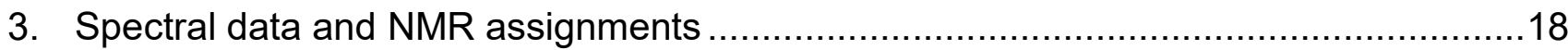

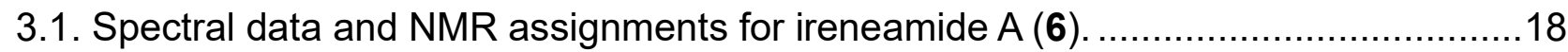

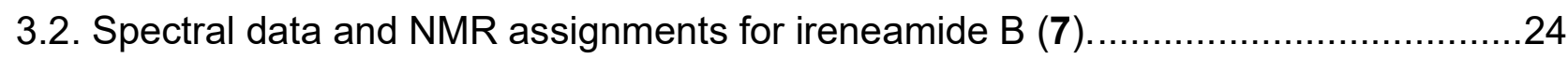

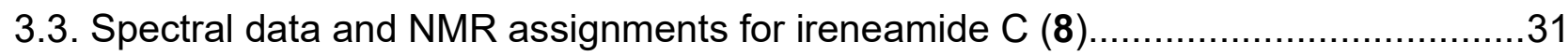

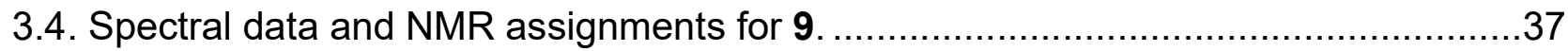

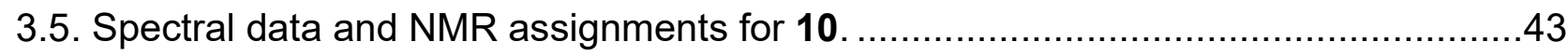

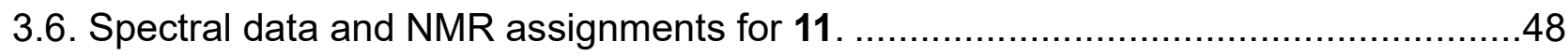

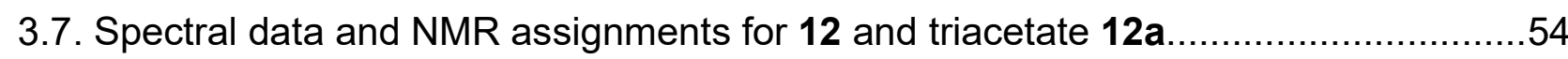

3.8. Physiochemical properties, spectral data and NMR assignments for 3,7-

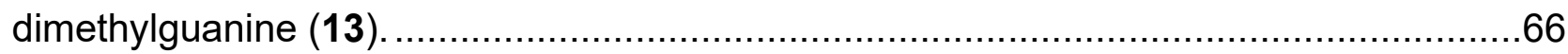

3.9. Spectral data and NMR assignments for ireneguanine (14) . .............................71

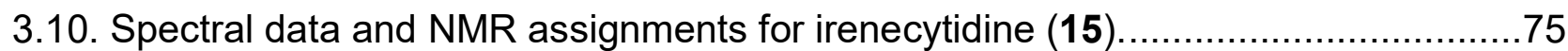

3.11. Spectral data and NMR assignments for 3-chlorotyramine (16). ......................81

3.12. Physicochemical properties, spectral data and NMR assignments for 3-

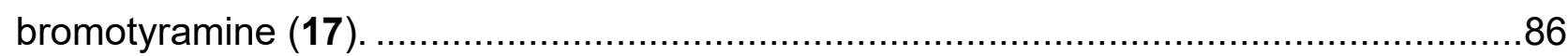

3.13. Spectral data and NMR assignments for 3-bromotyramine-O-sulfate (18)..........92

3.14. Physicochemical properties, spectral data and NMR assignments for tyramine-O-

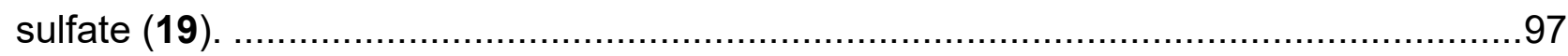

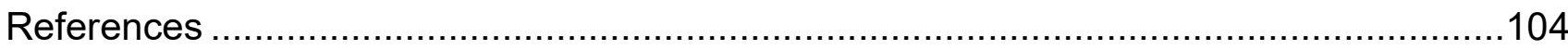




\section{Supporting results}

1.1. An HPLC chromatogram of an aromatic rich fraction of $C$. irene.

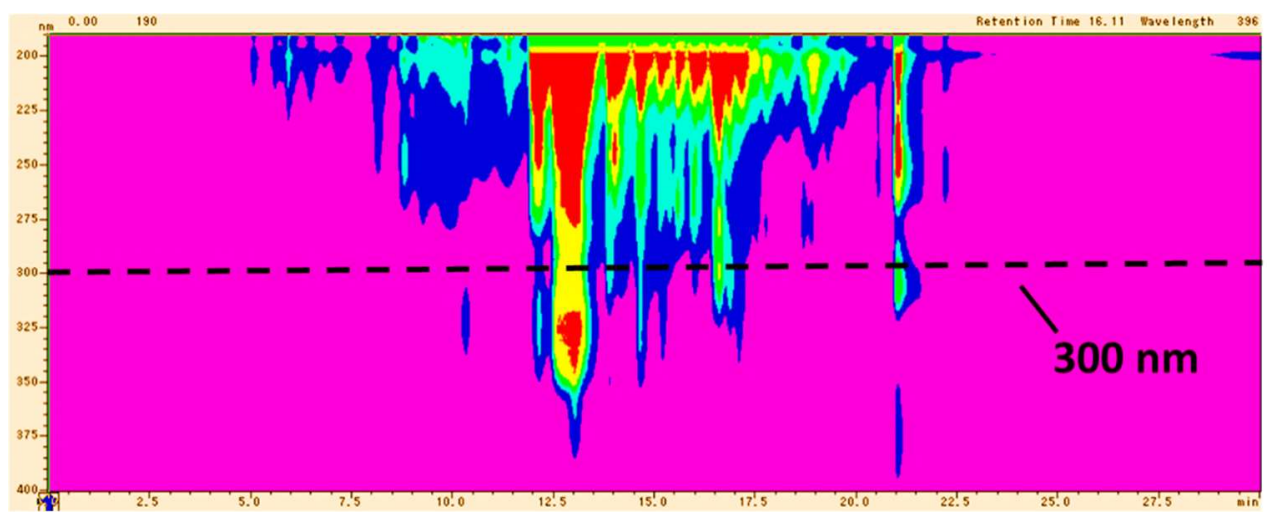

Figure S1. An HPLC-PDA chromatogram of an aromatic rich fraction. 
1.2. Physicochemical properties of authentic 6-biopterin $\mathrm{HCl}$ salt and characterization of hydrolysate of 9 (9a).

Authentic 6-biopterin $\mathrm{HCl}$ salt, yellow solid: $[\alpha]^{20} \mathrm{D}-59$ (c 0.011, $0.01 \mathrm{M}$ hydrochloric acid); UV (0.01 M hydrochloric acid) $\lambda_{\max }(\log \varepsilon) 274$ (3.49), $322(3.49) \mathrm{nm}$; ECD (1.7 mM, $0.01 \mathrm{M}$ hydrochloric acid) $\lambda_{\max }(\Delta \varepsilon) 229$ (+4.89), 248 (-5.65), $313(-3.28) \mathrm{nm} ;{ }^{1} \mathrm{H}$ NMR (DMSO- $\left.d_{6}, 400 \mathrm{MHz}\right) \delta 8.76(1 \mathrm{H}, \mathrm{s}, \mathrm{H}-7), \delta 4.47(1 \mathrm{H}, \mathrm{d}, J=5.5 \mathrm{~Hz}$, H-1'), $\delta 3.92\left(1 \mathrm{H}\right.$, quin, $\left.J=6.0 \mathrm{~Hz}, \mathrm{H}-2^{\prime}\right), \delta 1.05$ (3H, d, $J=6.4 \mathrm{~Hz}, \mathrm{H}-3^{\prime}$ ) (Figure S6, S12).

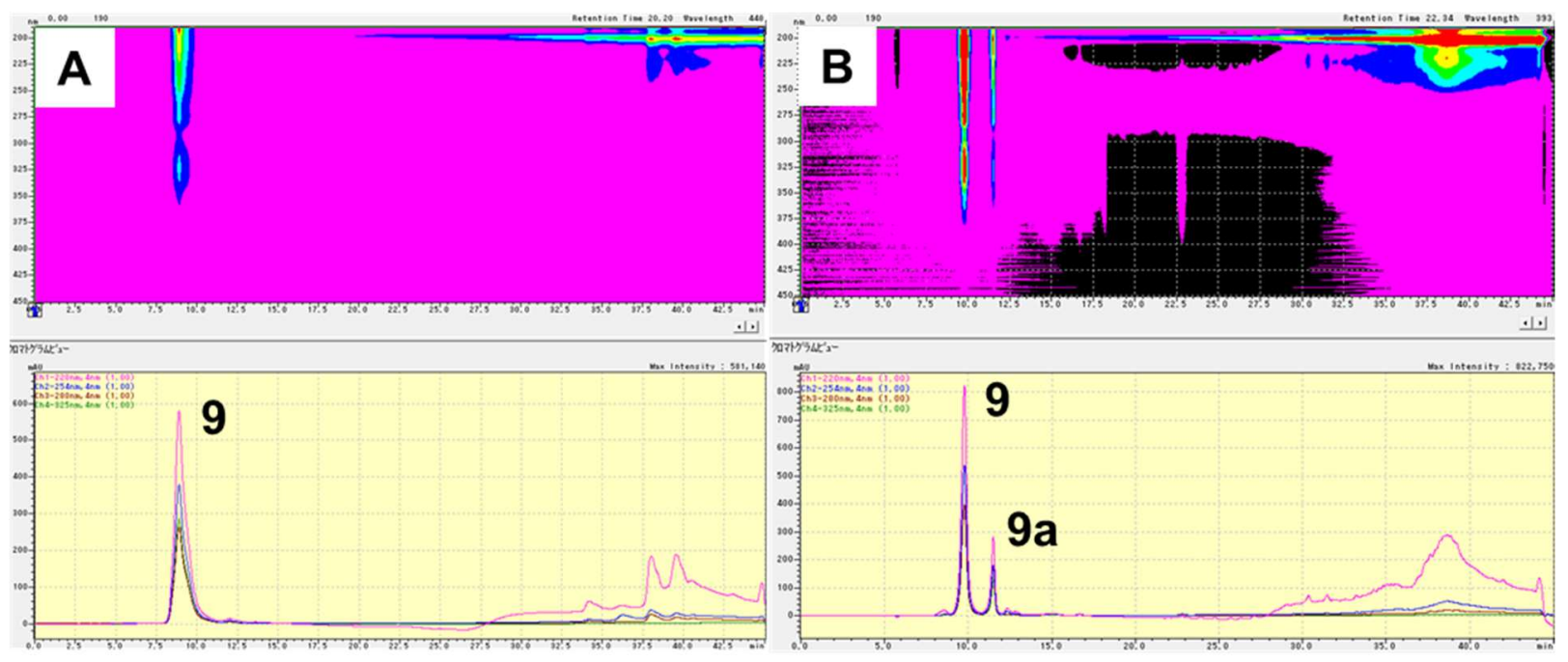

Figure S2. HPLC chromatograms of (A) 9 and (B) partially hydrolyzed 9. 
238.0927 / 5.26, subrange from 6-biopterin

238.0927 / 5.26 , entire range
MS/MS triggered at RT $=5.1255$
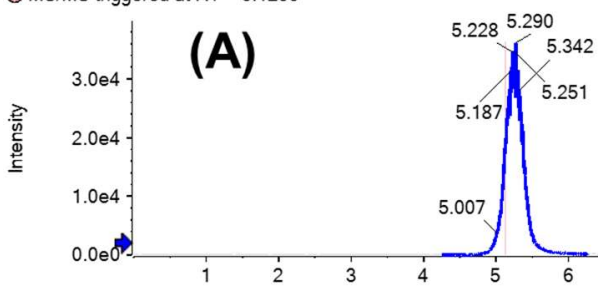

$238.0927 / 5.26$, subrange from TD8-32-3 O $238.0927 / 5.26$, entire range

OMSIMS tigged at RT $=5.1832$
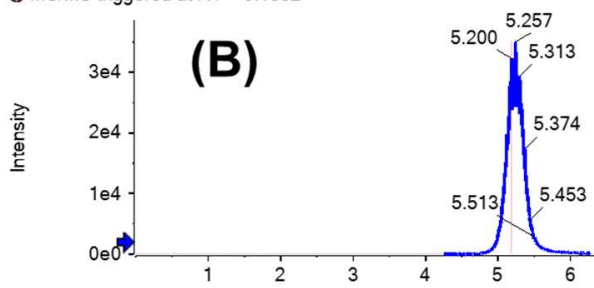

Figure S3. Extracted ion chromatograms of (A) authentic 6-biopterin and (B) 9a. 


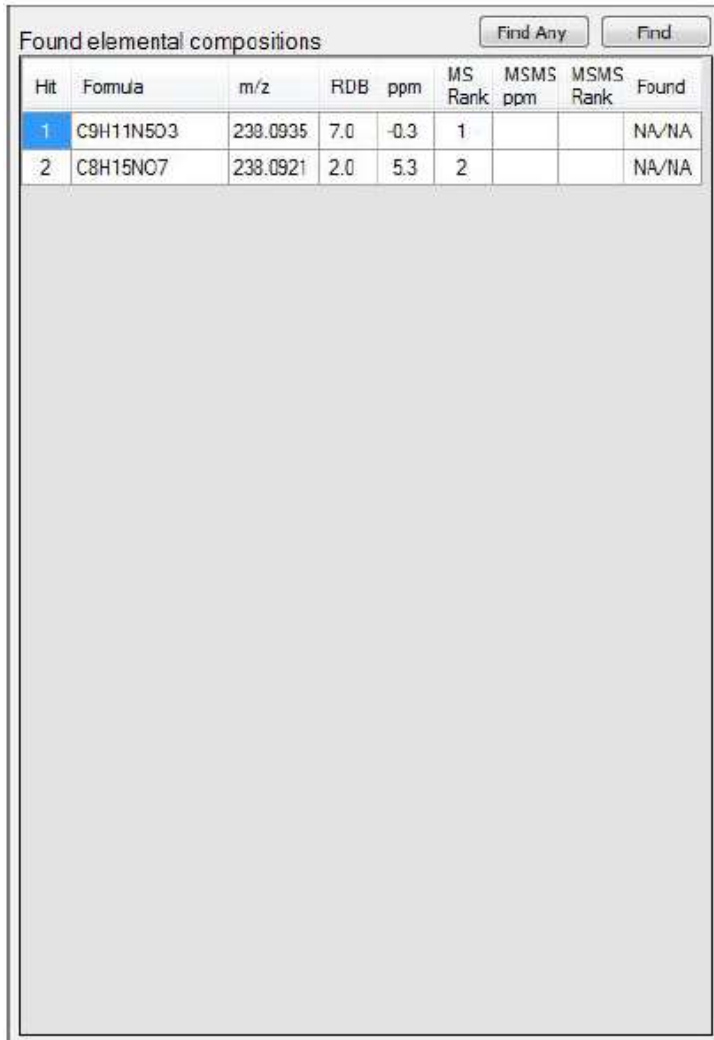

MS Details MSMS Details / Compound Detaile

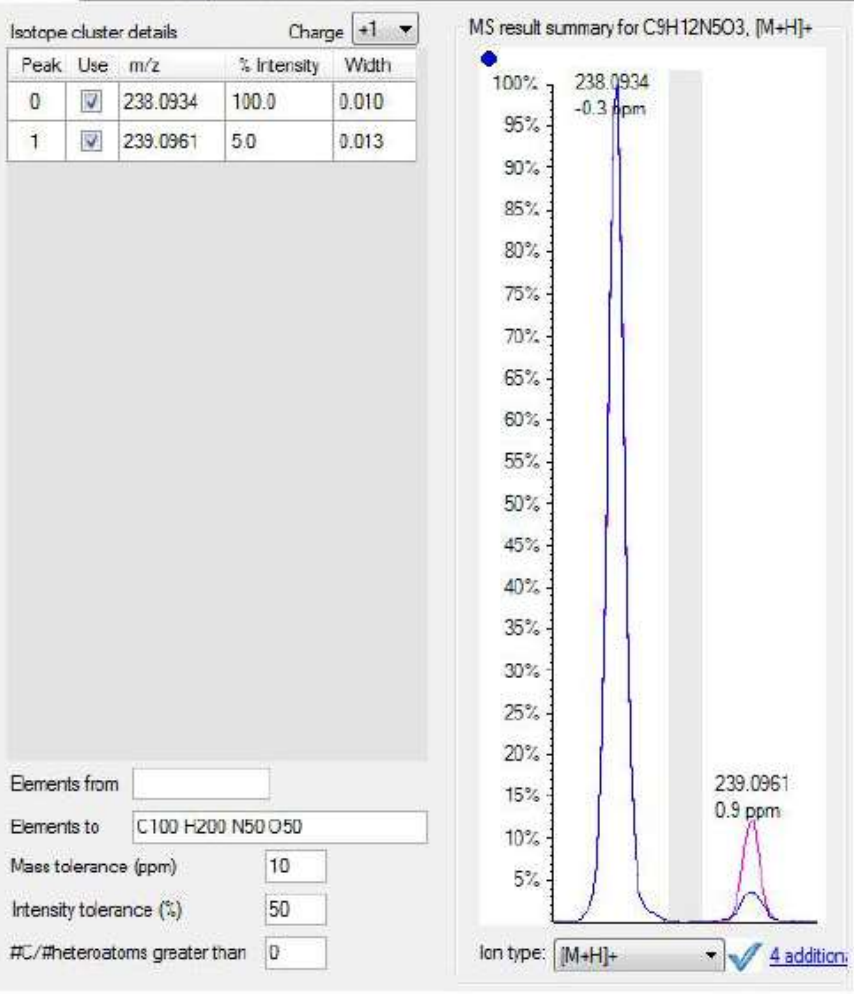

Figure S4. HRESIMS data for $9 \mathbf{a}$.

Spectrum from 6-biopterin.wiff (sample 1) - 6-biopterin, Experiment 2, +TOF MS^2 $(20$ - 1200) from $5.126 \mathrm{~min}$ Precursor: 238.1 Da CE=0

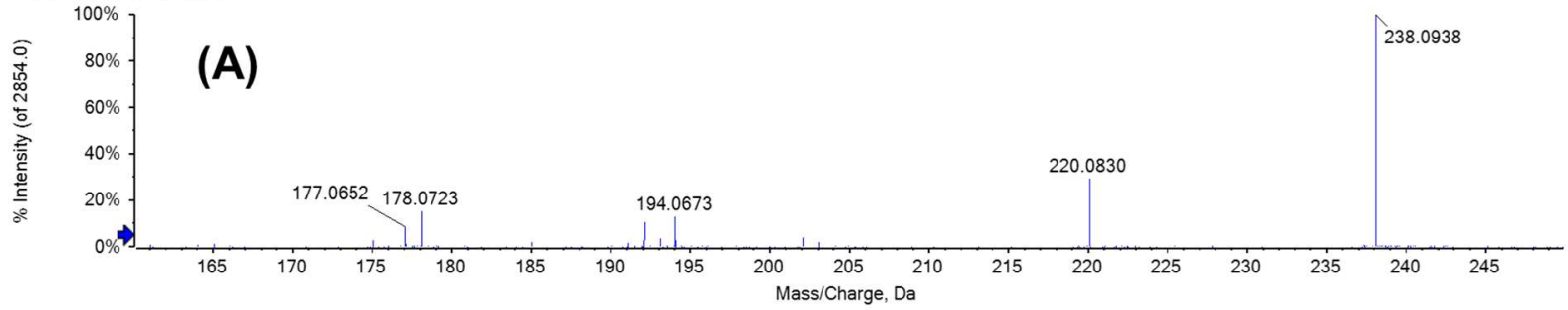
Spectrum from TD8-32-3.wiff (sample 1) - TD8-32-3, Experiment 2, +TOF MS^2 (20 - 1200) from $5.183 \mathrm{~min}$ Precursor: $238.1 \mathrm{Da} \mathrm{CE}=0$

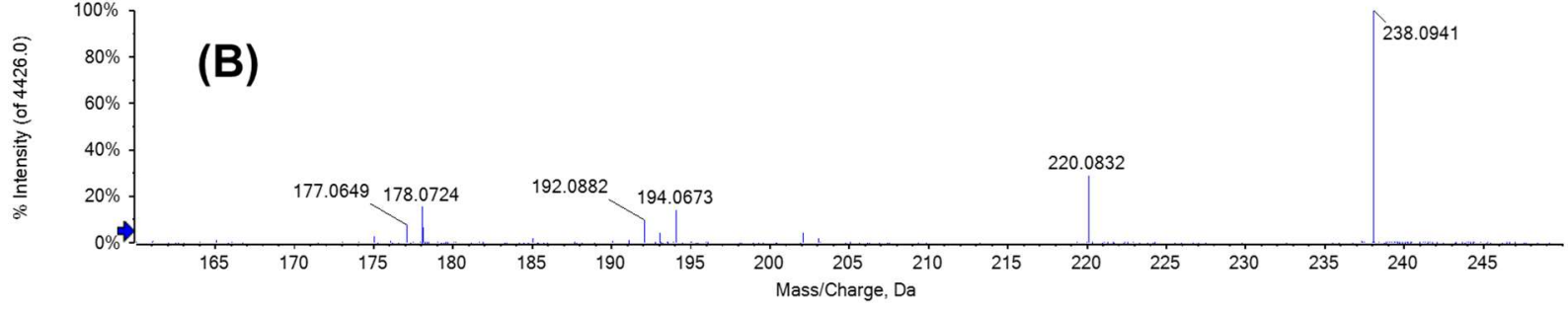

Figure S5. HRESI MS/MS spectra of (A) 6-biopterin and (B) 9a. 


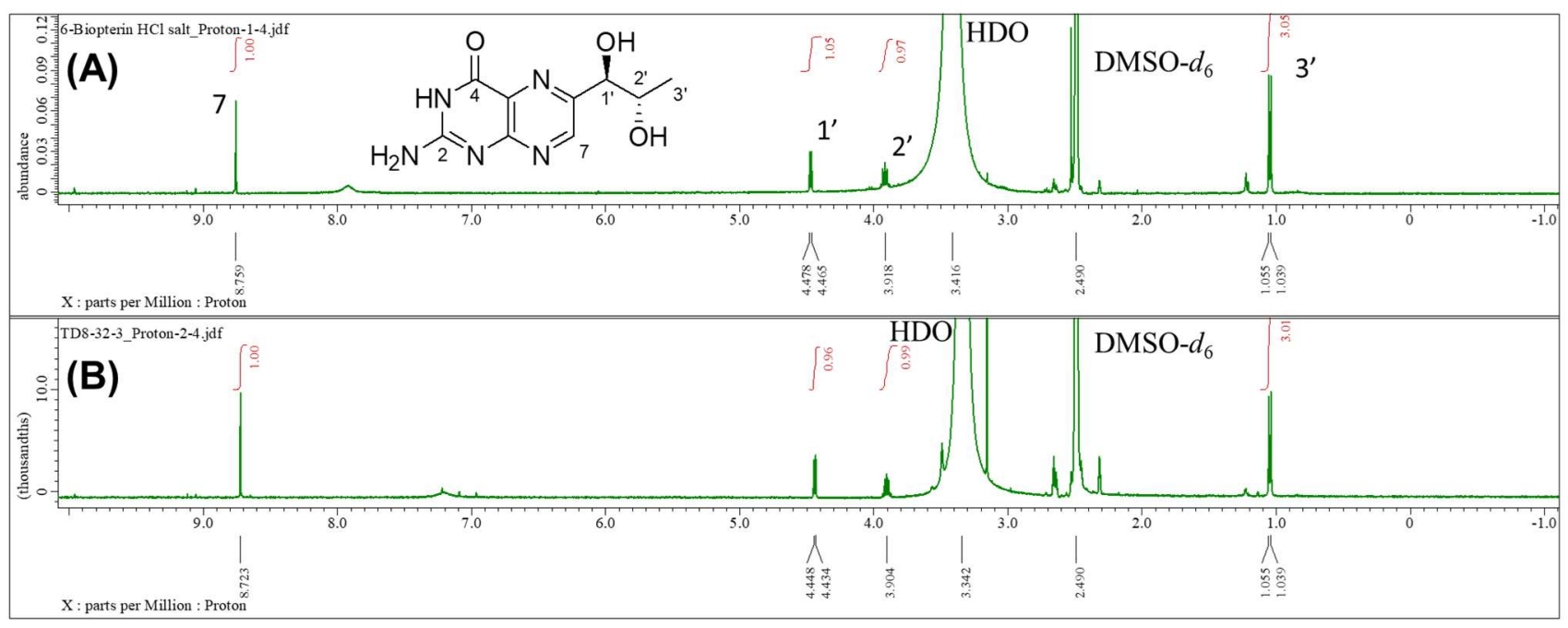

Figure S6. ${ }^{1} \mathrm{H}$ NMR spectra of authentic (A) 6-biopterin $\mathrm{HCl}$ salt and (B) 9a in DMSO-d $(400 \mathrm{MHz}$ ).

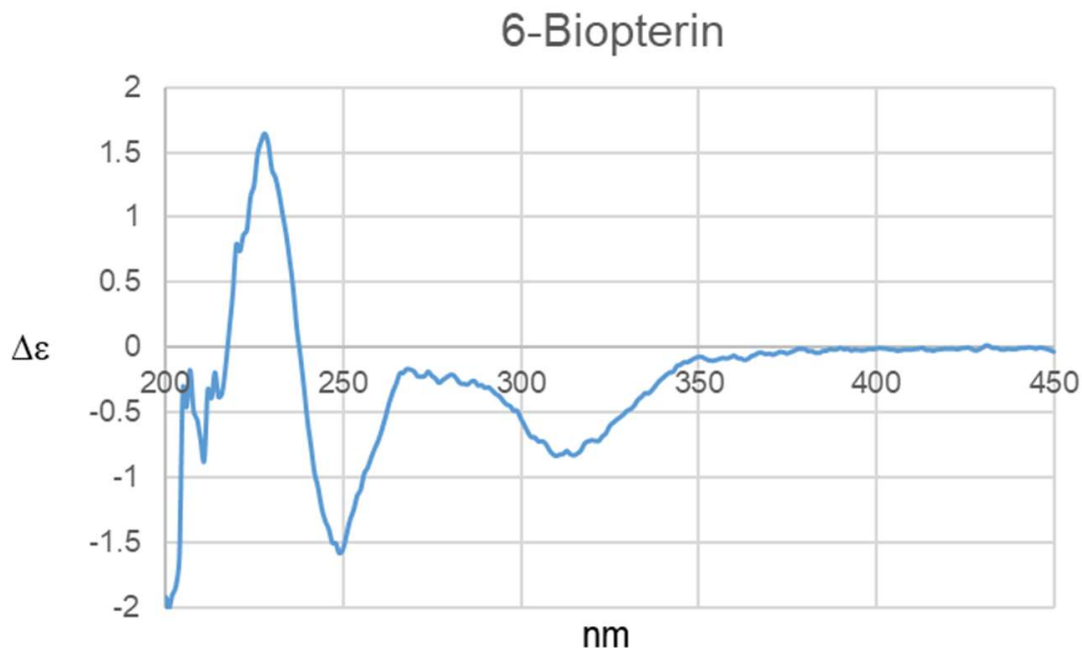

(9a)

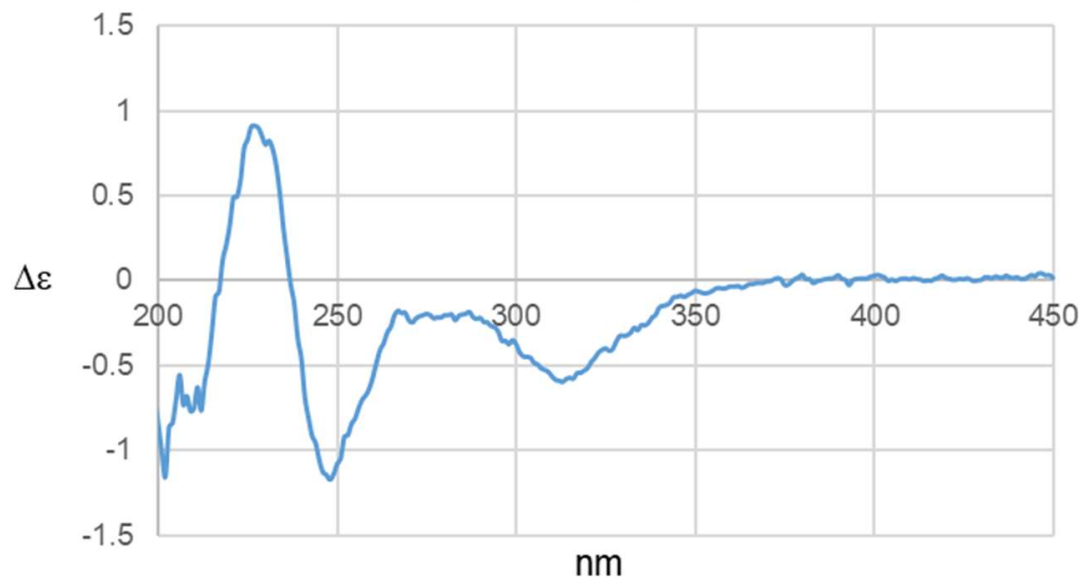

Figure S7. ECD spectra of authentic 6-biopterin and 9a. 
1.2. Characterization of hydrolysate of 10 (10a).

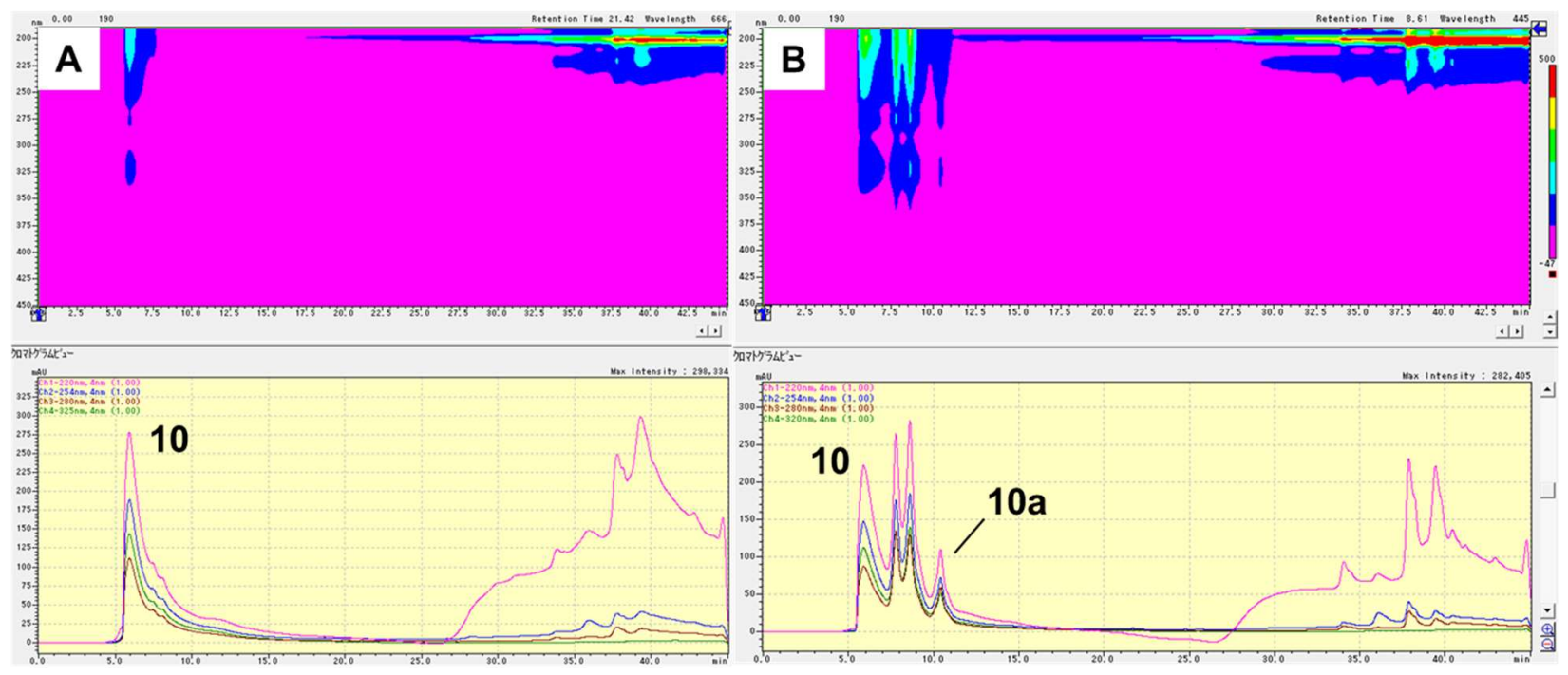

Figure S8. HPLC chromatograms of (A) 10 and (B) partially hydrolyzed 10.

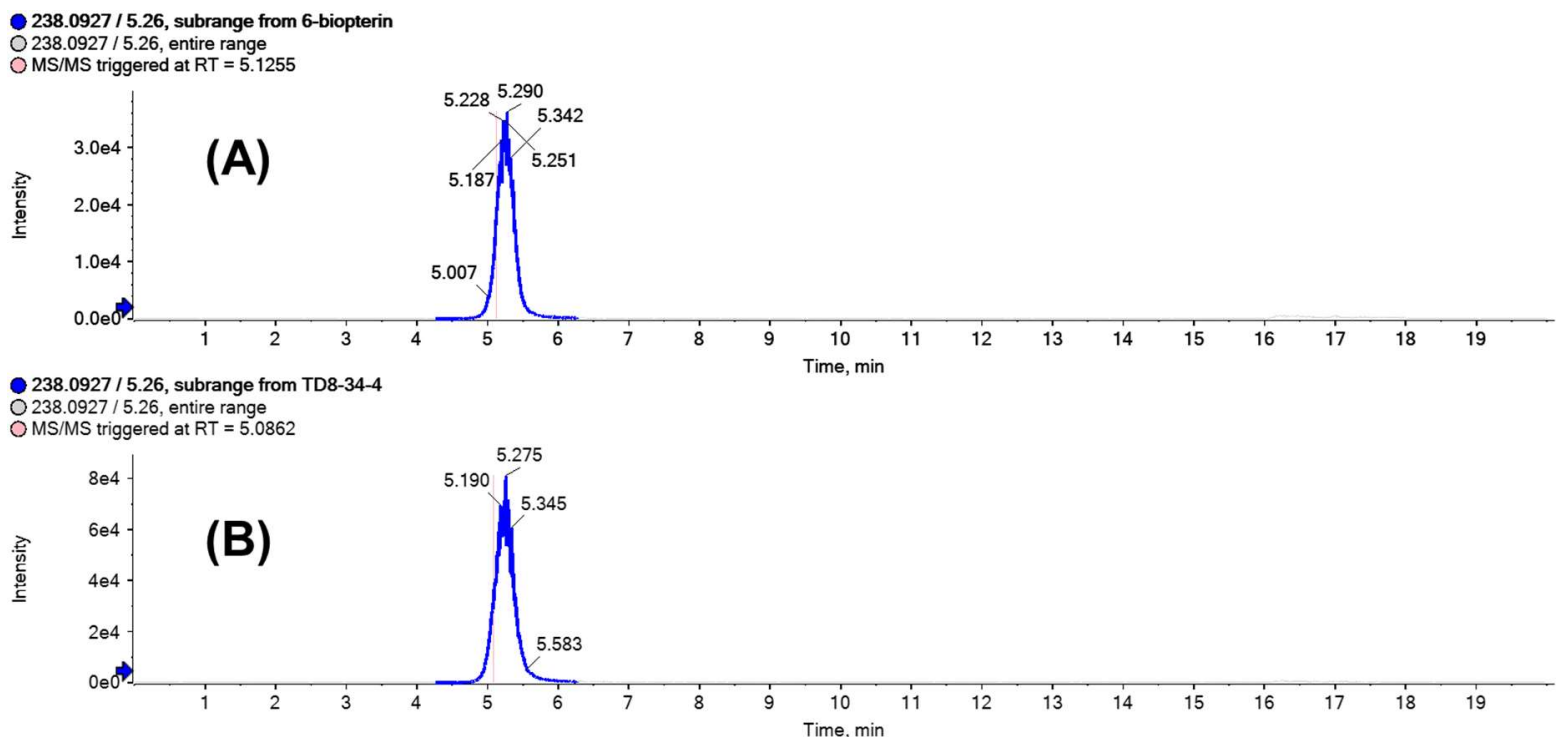

Figure S9. Extracted ion chromatograms of (A) authentic 6-biopterin and (B) 10a. 


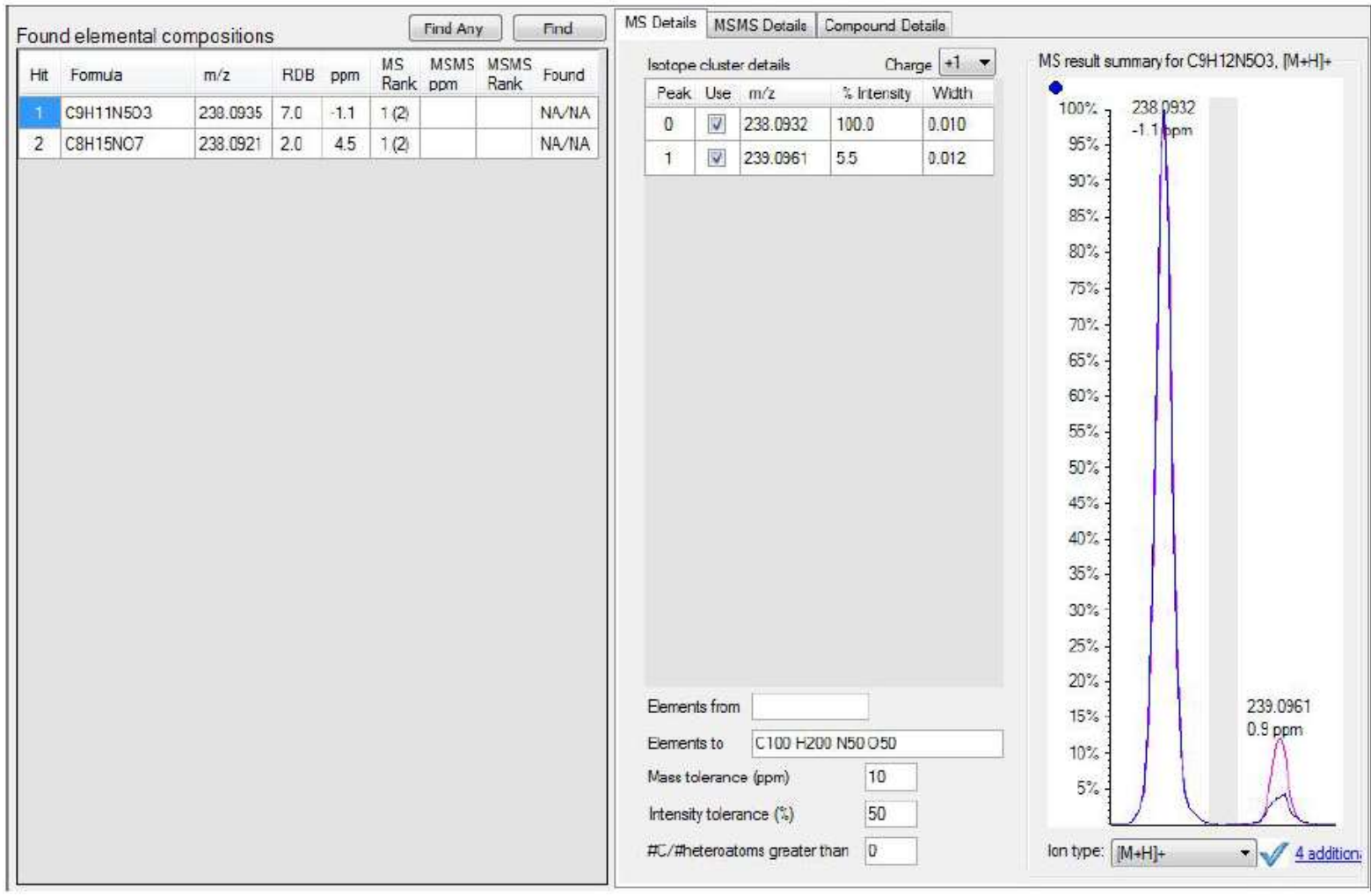

Figure S10. HRESIMS data for 10a.

Spectrum from 6-biopterin.wiff (sample 1) - 6-biopterin, Experiment 2, +TOF MS^2 (20 - 1200) from 5.126 min Precursor: $238.1 \mathrm{Da} \mathrm{CE}=0$

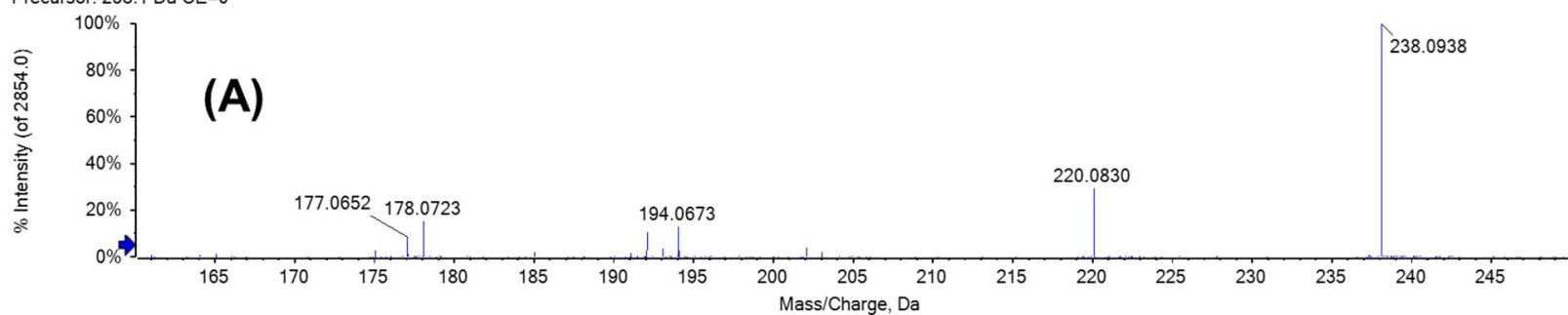

Spectrum from TD8-34-4. wiff (sample 1) - TD8-34-4, Experiment 2, +TOF MS^2 (20 - 1200) from 5.086 min

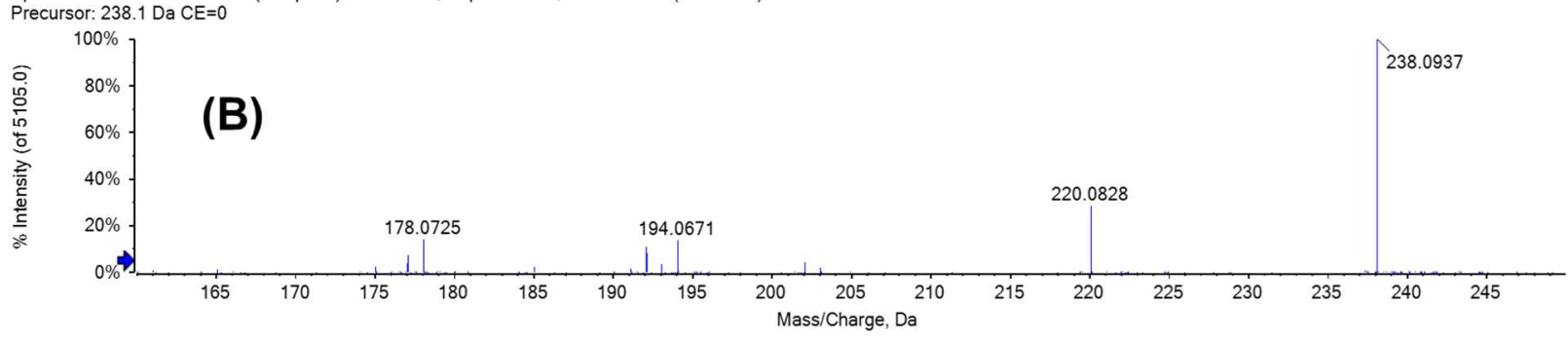

Figure S11. HRESI MS/MS spectra of (A) authentic 6-biopterin and (B) 10a. 


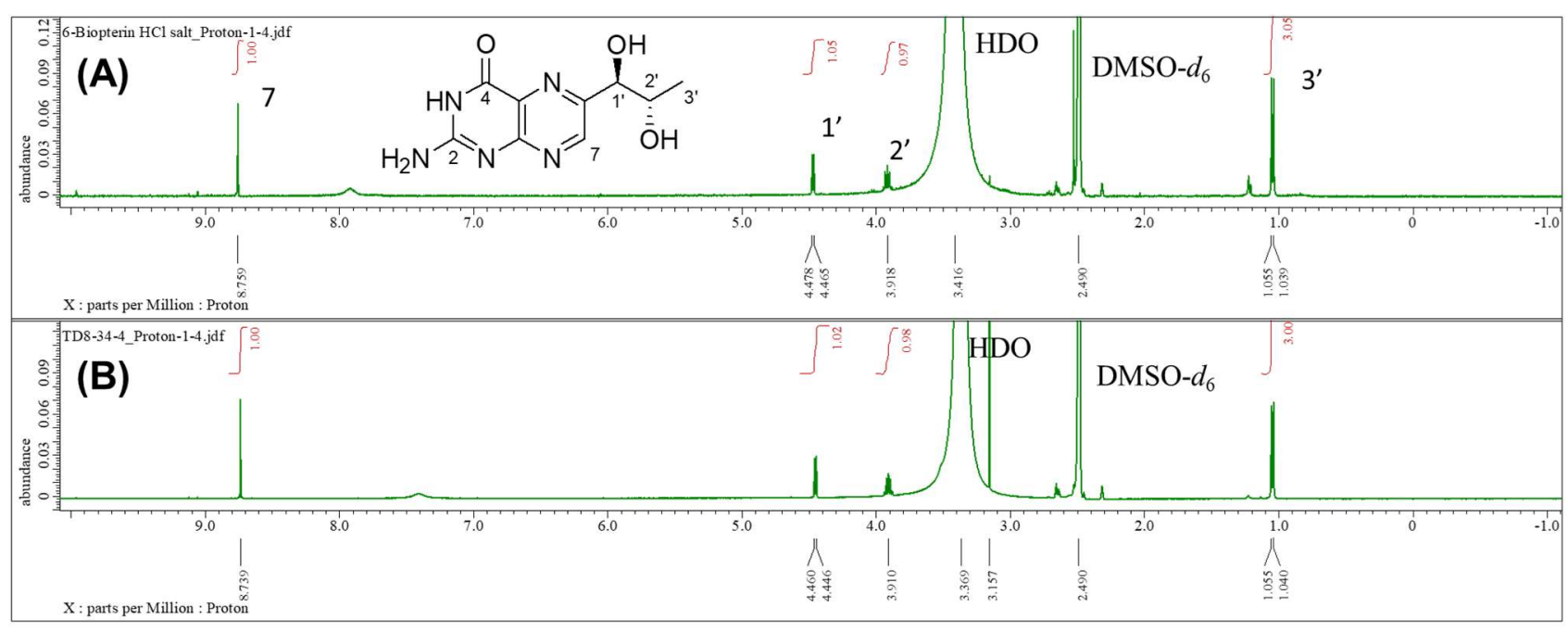

Figure S12. ${ }^{1} \mathrm{H}$ NMR spectra authentic of (A) authentic 6-biopterin $\mathrm{HCl}$ salt and (B) 10a in DMSO- $d_{6}(400 \mathrm{MHz})$.

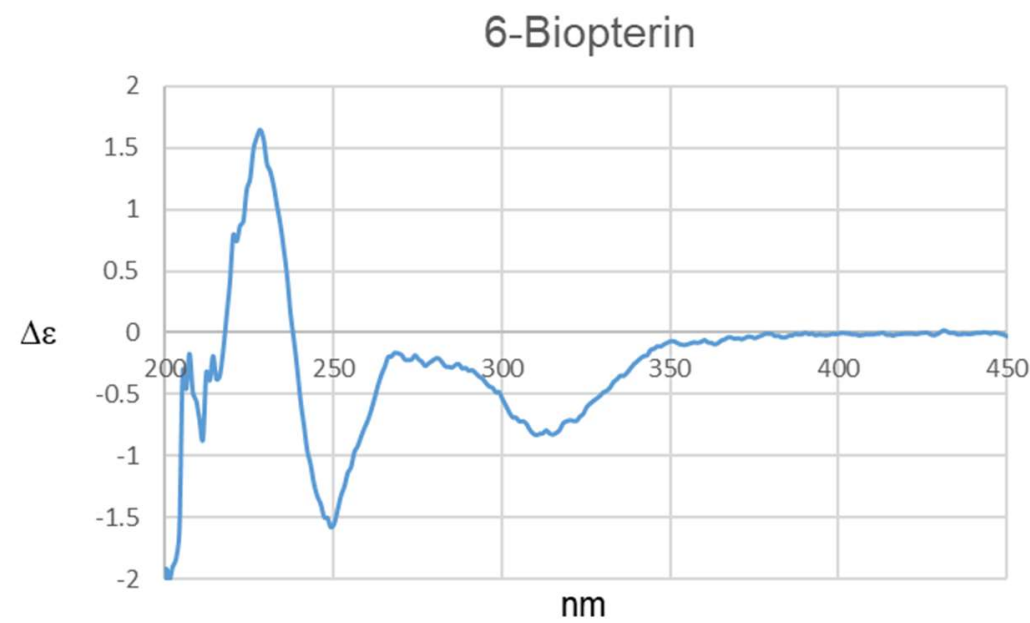

$10 \mathrm{a}$

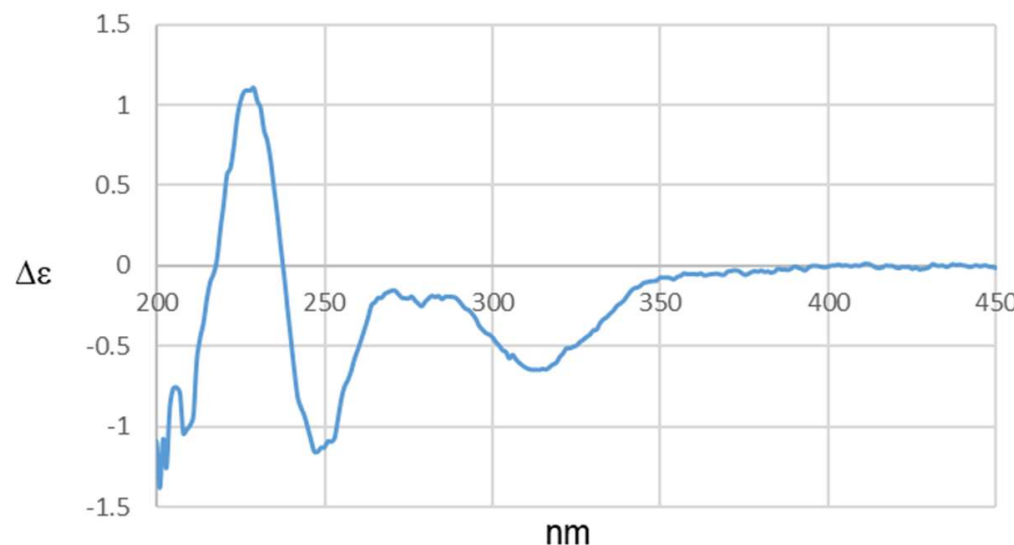

Figure S13. ECD spectra of authentic 6-biopterin and 10a. 
<smiles>C[C@H](OC(C)(C)C)[C@@H](OC(C)(C)C)c1nc2c(=O)nc(NC3CCCCC3)n(C)c2[nH]c1=O</smiles>

$12 \mathrm{a}$
B<smiles>CC(=O)OC(c1ccccc1)[C@H](C)OC(C)=O</smiles>

20<smiles>CC(=O)O[C@@H](c1cnc2c(n1)c(=O)[nH]c(=O)n2C)[C@@H](C)OC(C)=O</smiles>

$21 a$

Figure S14. Structures of (A) triacetate (12a), (B) 1,2-diacetyl-1-arylpropane (20) ${ }^{1}$ and (C) (1'R, 2' $\left.S\right)-6-\left(1^{\prime}, 2^{\prime}-\right.$ dihydroxypropyl)-1-methylpteridine-2,4-dione (21a) . ${ }^{2}$

Table S1. ${ }^{1} \mathrm{H}$ NMR data comparison of $12 \mathbf{a}$ with 20 and $\mathbf{2 1 a}$.

\begin{tabular}{|c|c|c|c|c|c|}
\hline \multirow{3}{*}{$\#$} & \multicolumn{5}{|c|}{$\delta_{\mathrm{H}}$ mult. $(J$ in $\mathrm{Hz})$} \\
\hline & \multirow{2}{*}{$12 \mathbf{a}^{a}$} & \multirow{2}{*}{$12 a^{b}$} & \multicolumn{2}{|c|}{$\mathbf{2 0}^{c, 1}$} & \multirow{2}{*}{$\mathbf{2 1} \mathbf{a}^{d, 2}$} \\
\hline & & & Erythro & Threo & \\
\hline H-1' & $5.97, \mathrm{~d}(3.2)$ & $6.10, \mathrm{~d}(4.1)$ & $(J=4.0)$ & $(J=7.5)$ & $6.02, \mathrm{~d}(4.2)$ \\
\hline $\mathrm{H}-2^{\prime}$ & $5.34, \mathrm{dq}(6.4,3.5)$ & $5.45, \mathrm{dq}(6.6,4.4)$ & $(J=4.0,6.5)$ & $(J=7.5,6.0)$ & $5.46, \mathrm{dq}(6.6,4.2)$ \\
\hline H-3' & $1.12, \mathrm{~d}(6.4)$ & $1.27, \mathrm{~d}(6.4)$ & $(J=6.5)$ & $(J=6.0)$ & $1.30, \mathrm{~d}(6.6)$ \\
\hline
\end{tabular}


1.4. Semi-quantitative LC-MS analysis.

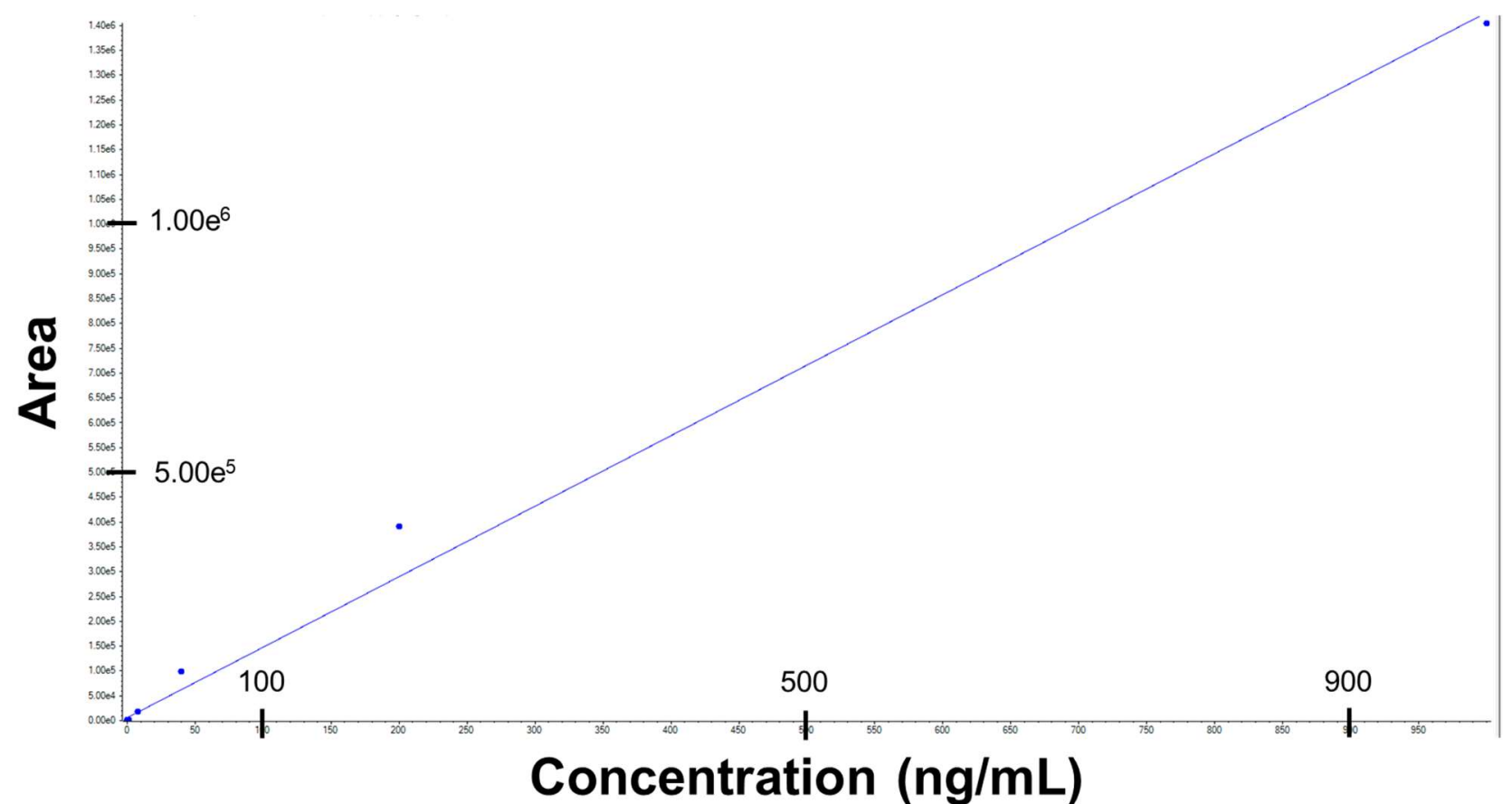

Figure S15. The standard curve of irenecarboline A (1) for semi-quantitative LC-MS analysis. Areas of $\mathbf{1}$ at each concentration $(1,8,40,200,1000 \mathrm{ng} / \mathrm{mL}$ respectively) are plotted.

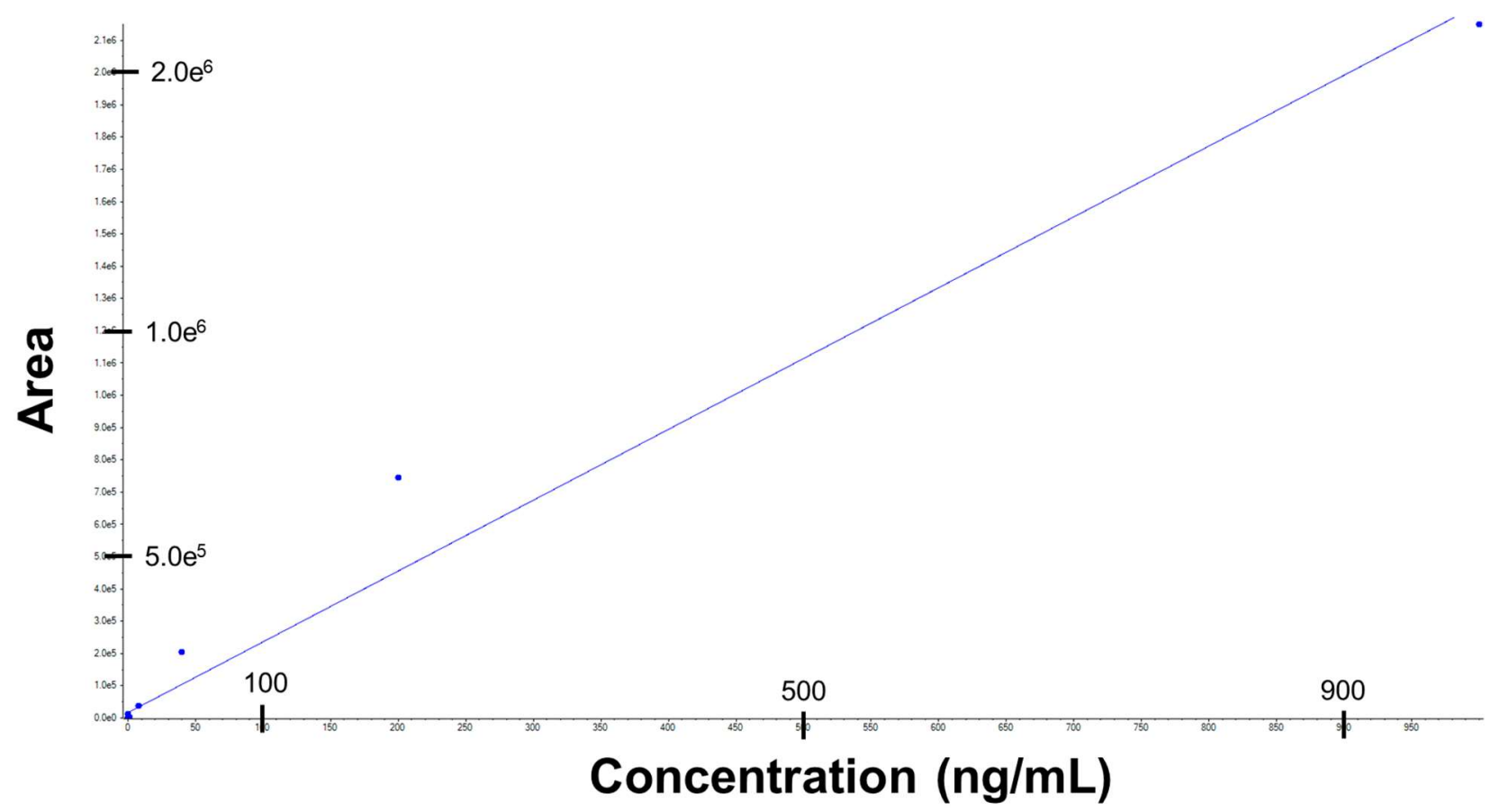

Figure S16. The standard curve of $N$-methyl- $\beta$-carbolinium chloride (3) for semi-quantitative LC-MS analysis. Areas of 3 at each concentration $(1,8,40,200,1000 \mathrm{ng} / \mathrm{mL}$ respectively) are plotted. 


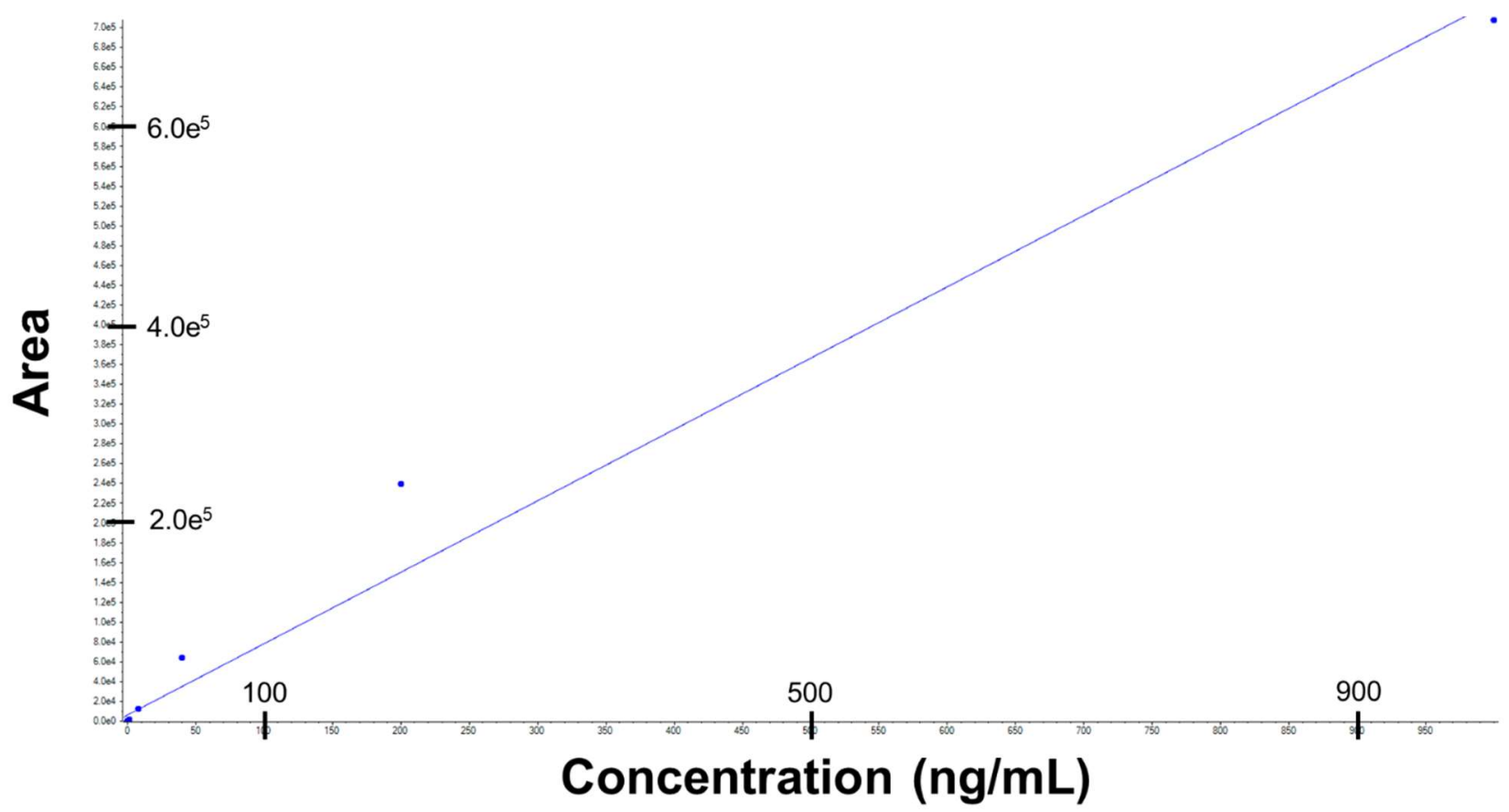

Figure S17. The standard curve of 1,3,9-trimethyl-8-oxoisoguanine (5) for semi-quantitative LC-MS analysis. Areas of 5 at each concentration $(1,8,40,200,1000 \mathrm{ng} / \mathrm{mL}$ respectively) are plotted.

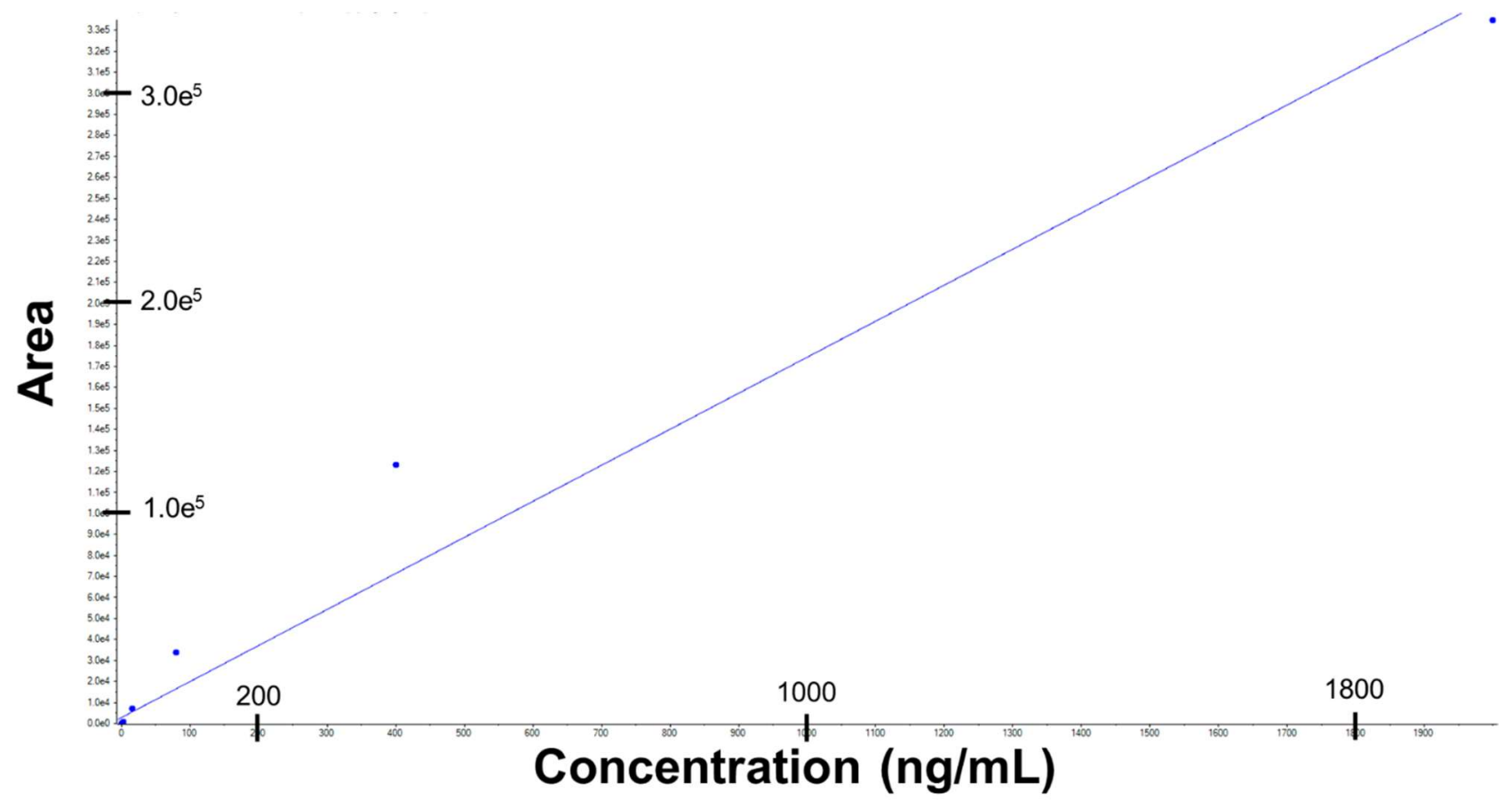

Figure S18. The standard curve of irenepterin D (12) for semi-quantitative LC-MS analysis. Areas of 12 at each concentration $(2,16,80,400,2000 \mathrm{ng} / \mathrm{mL}$ respectively) are plotted. 


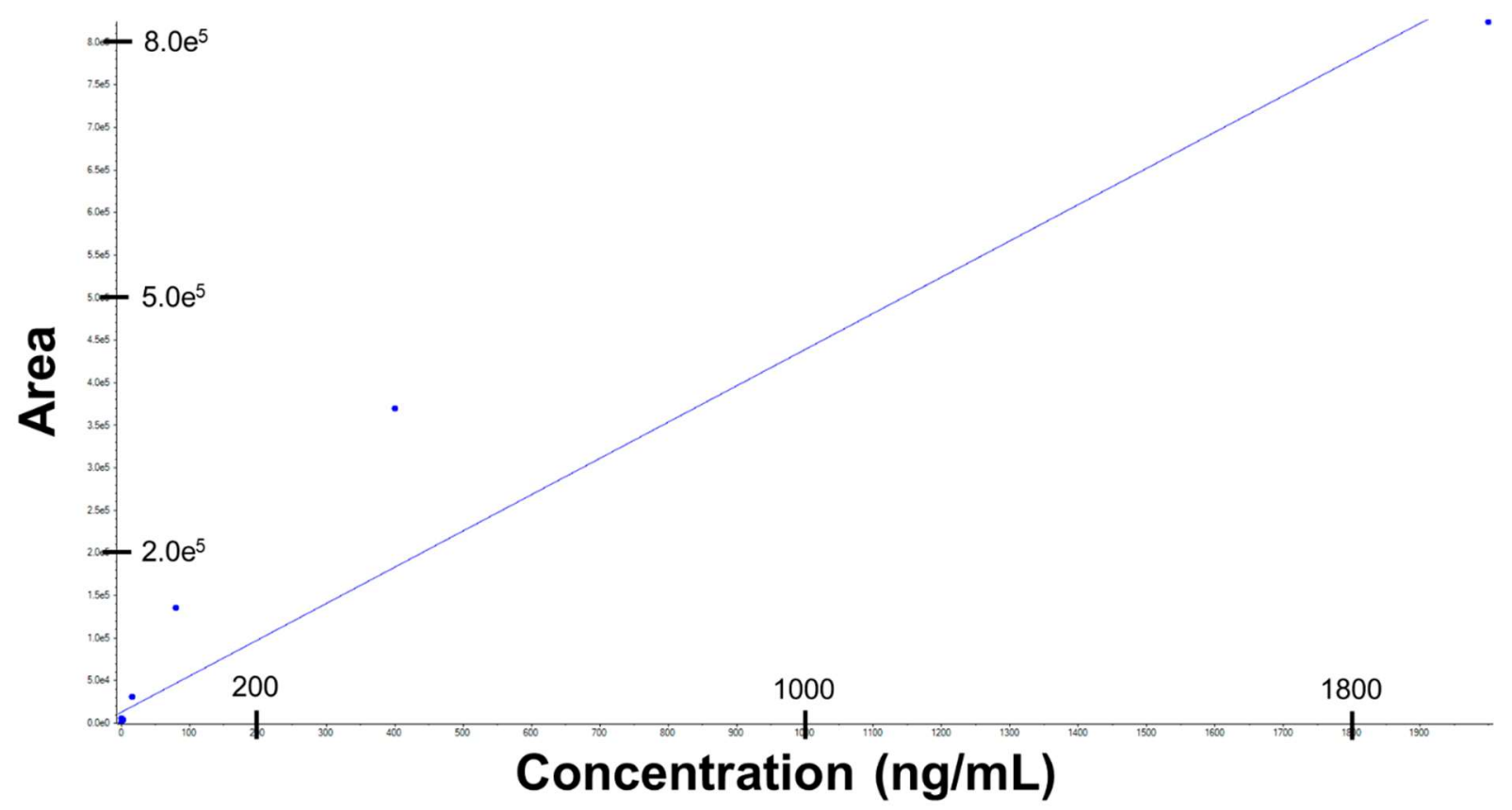

Figure S19. The standard curve of homarine for semi-quantitative LC-MS analysis. Areas of homrine at each concentration $(2,16,80,400,2000 \mathrm{ng} / \mathrm{mL}$ respectively) are plotted.

Table S2. Content rates of compounds 1, 3, 5, 12 and homarine.

\begin{tabular}{ccccccc} 
& \multicolumn{5}{c}{ Content rate (w/w \%) } \\
\cline { 2 - 7 } Compound & Adults & Juveniles & Larvae & Eggs & Serum & Blood cells \\
\hline $\mathbf{1}$ & 2.7 & $0.02^{a}$ & $0^{a, b}$ & $0.03^{a}$ & 1.2 & 0.3 \\
$\mathbf{3}$ & 3.5 & $0.01^{a}$ & $0^{a, b}$ & 0.2 & 1.6 & 0.3 \\
$\mathbf{5}$ & 2.3 & $0^{a, b}$ & $0^{a, b}$ & 0.9 & 0.9 & 0.2 \\
$\mathbf{1 2}$ & 10.5 & 0.0 & 0.0 & 0.0 & 1.3 & 6.2 \\
Homarine & 13.5 & 8.3 & $0^{a, b}$ & 8.4 & 5.0 & 0.9 \\
\hline
\end{tabular}

${ }^{a}$ These ions detected at trace levels. ${ }^{b}$ Peak areas of these ions were under limit of quantification. 


\subsection{Larval metamorphosis-inducing activities}

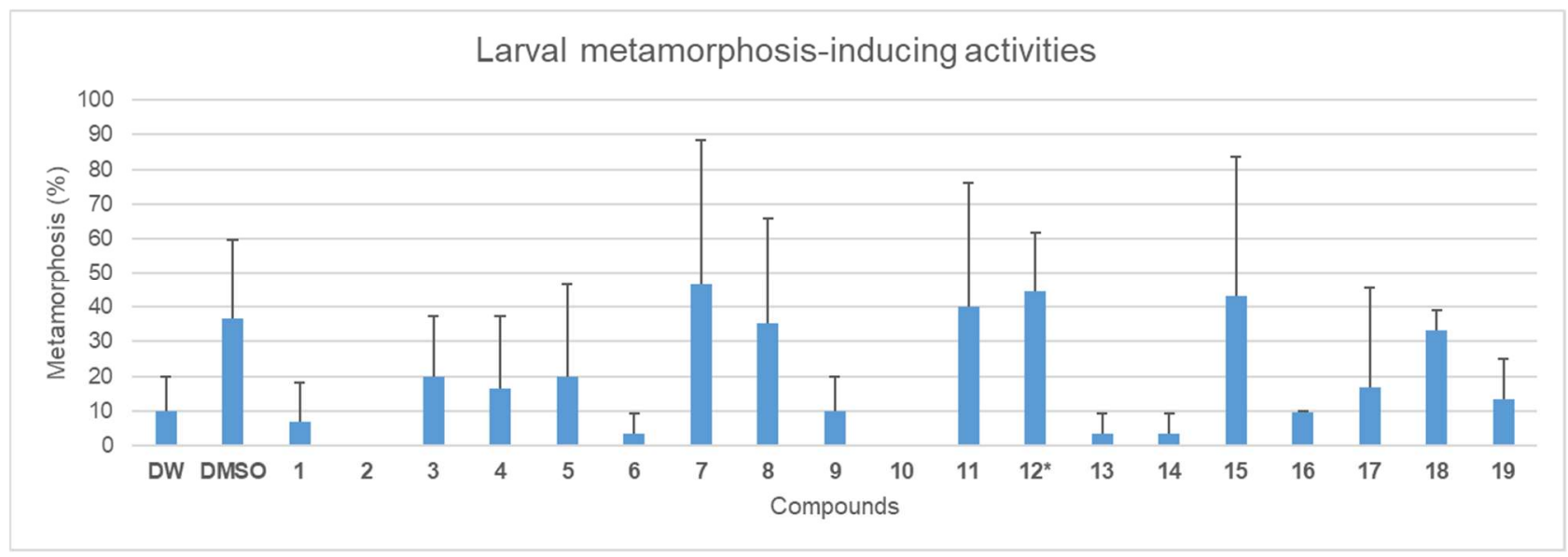

Figure S20. Larval metamorphosis-inducing activities of compounds 1-19 at $10 \mu \mathrm{g} / \mathrm{mL}$ approximately (Bars: standard deviation, $\mathrm{n}=3$ ). Distilled water (DW) and dimethyl-sulfoxide (DMSO) were used for negative control. *Compound 12 was solely dissolved in DMSO.

1.6. AChE inhibition and cytotoxicity assay.

Table S3. AChE inhibition and cytotoxixity of compounds 13-14, 16-17.

\begin{tabular}{ccc} 
compound & inhibition $^{a}$ & cell viability $^{b}$ \\
\hline $\mathbf{1}^{c}$ & 80 & Not tested \\
$\mathbf{1 3}$ & 19.5 & Inactive \\
$\mathbf{1 6}$ & 47.3 & Inactive \\
$\mathbf{1 7}$ & 30.5 & 27.3 \\
\hline
\end{tabular}

${ }^{a}$ Inhibition $\%$ at $21.7 \mu \mathrm{g} / \mathrm{mL}$. Mean of triplicate. ${ }^{b}$ Cell viability $\%$ at $100 \mu \mathrm{g} / \mathrm{mL}$. Means of triplicate. ${ }^{c}$ Positive control. 


\section{Experimental section}

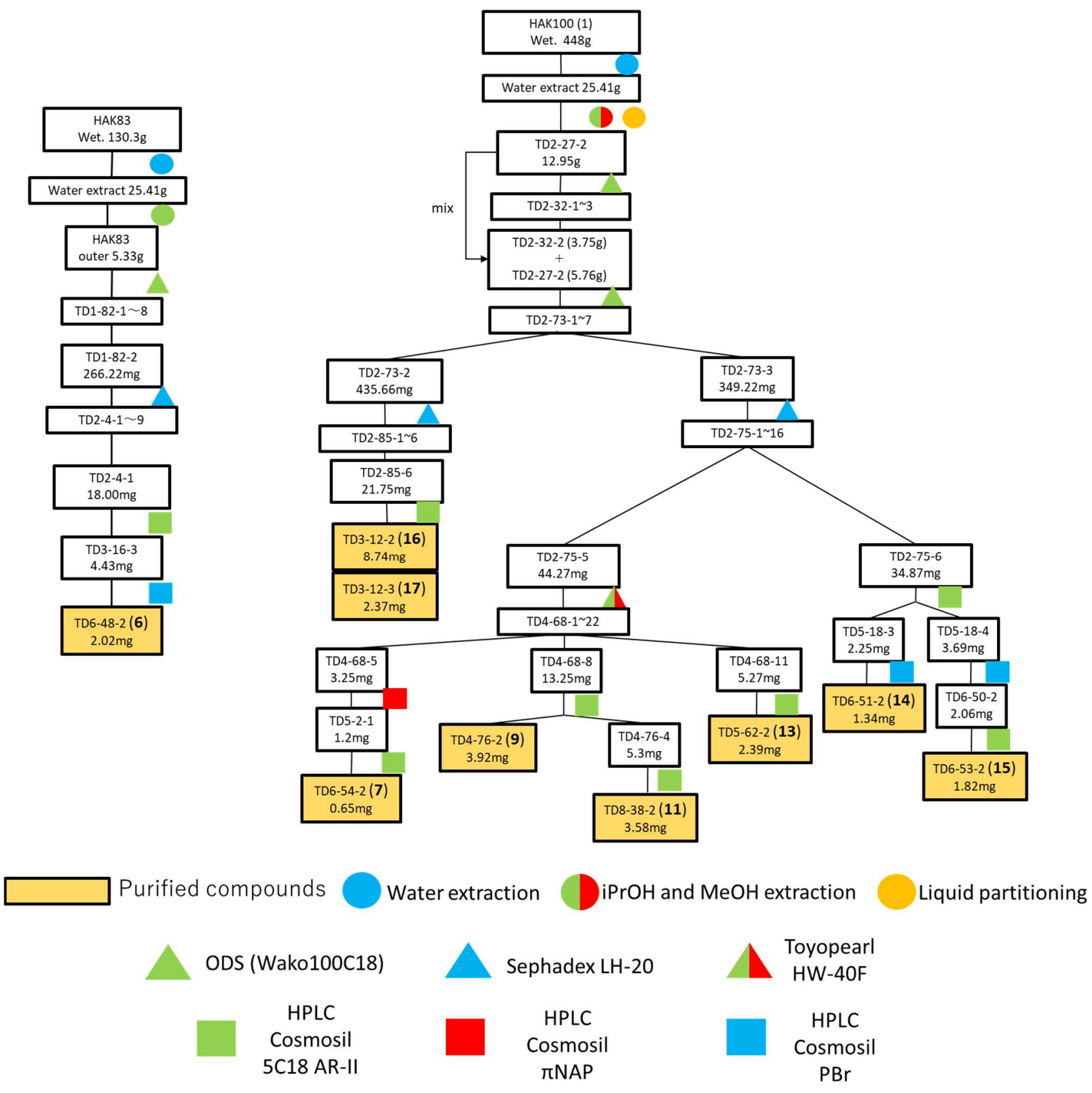

Figure S21. Separation schemes of compounds 6-7, 9, 11, 13-17. 

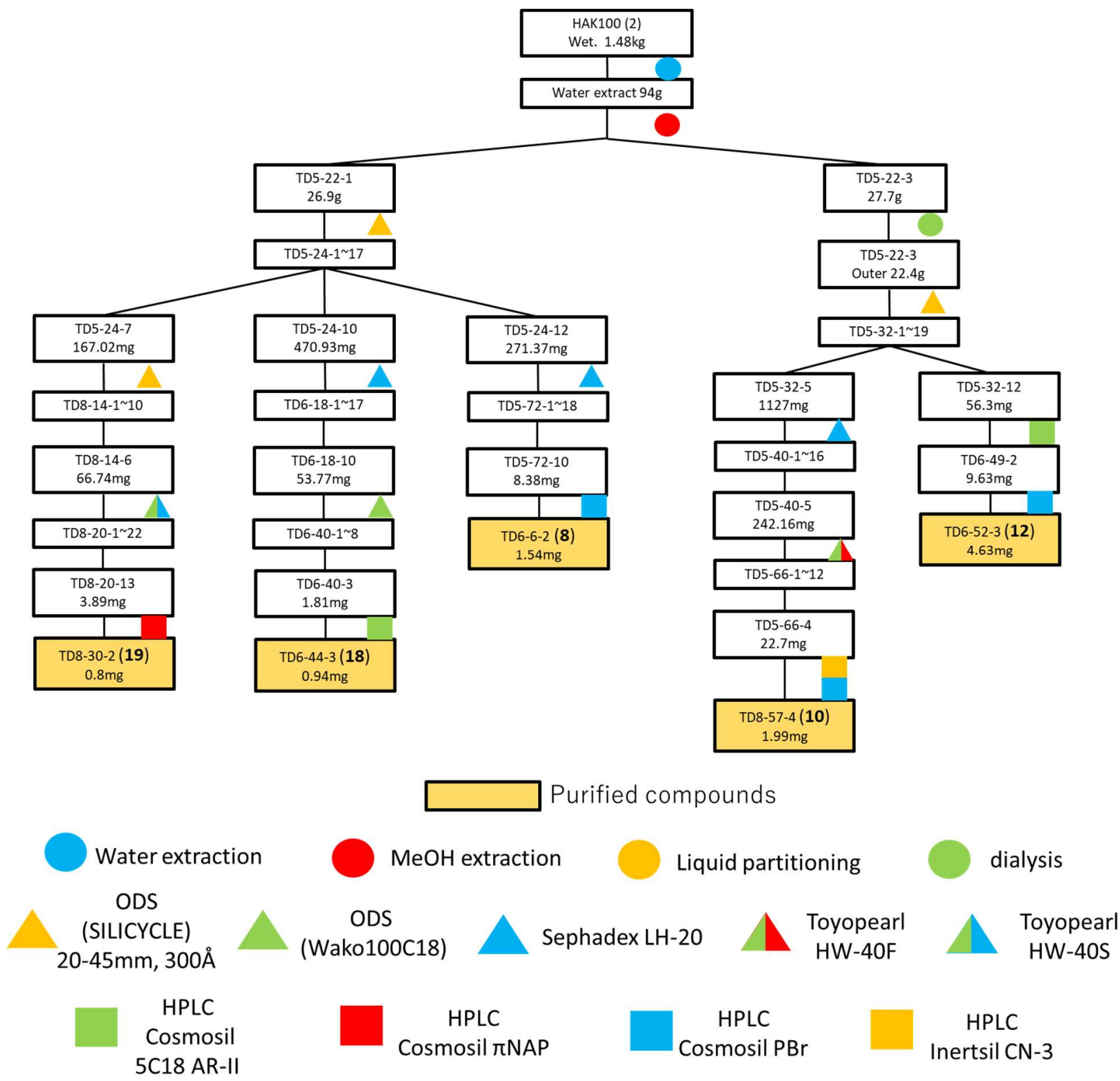

Figure S22. Separation scheme of compounds 8, 10, 12, 18-19. 


\section{Spectral data and NMR assignments}

3.1. Spectral data and NMR assignments for ireneamide A (6).

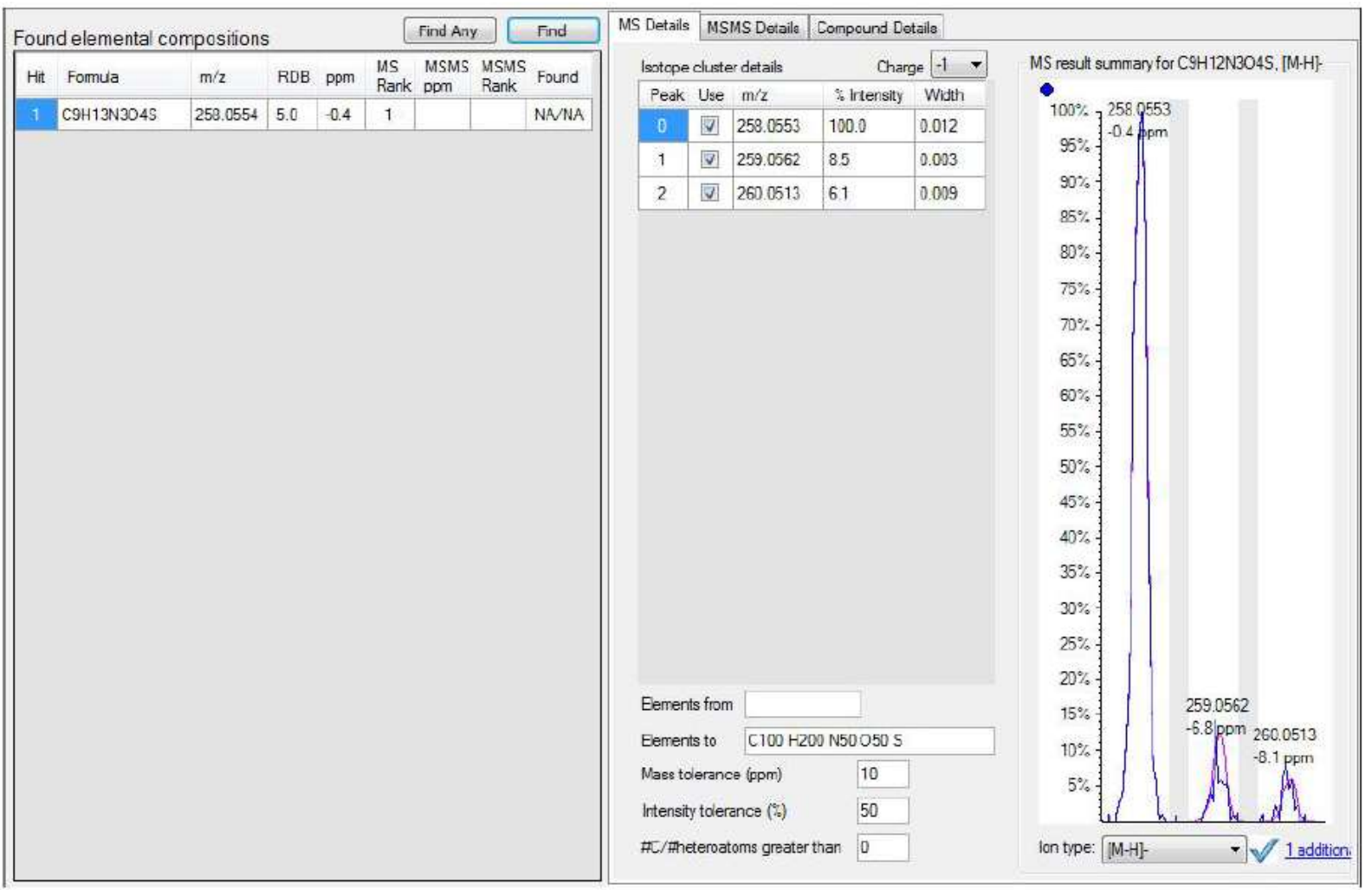

Figure S23. HRESIMS data for ireneamide A (6).

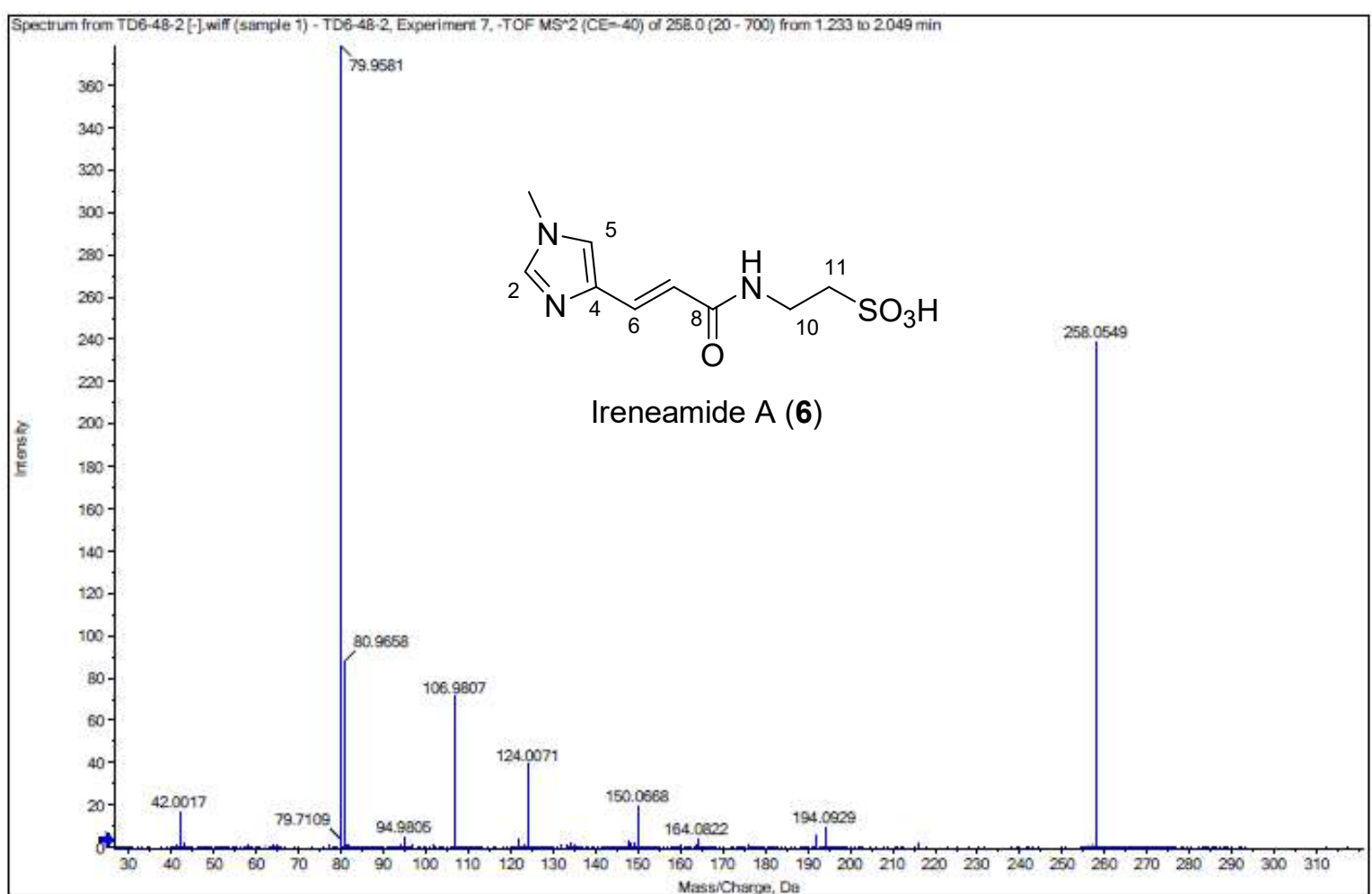

Figure S24. HRESI MS/MS spectrum of 6. Collision Energy (CE) -40V. 


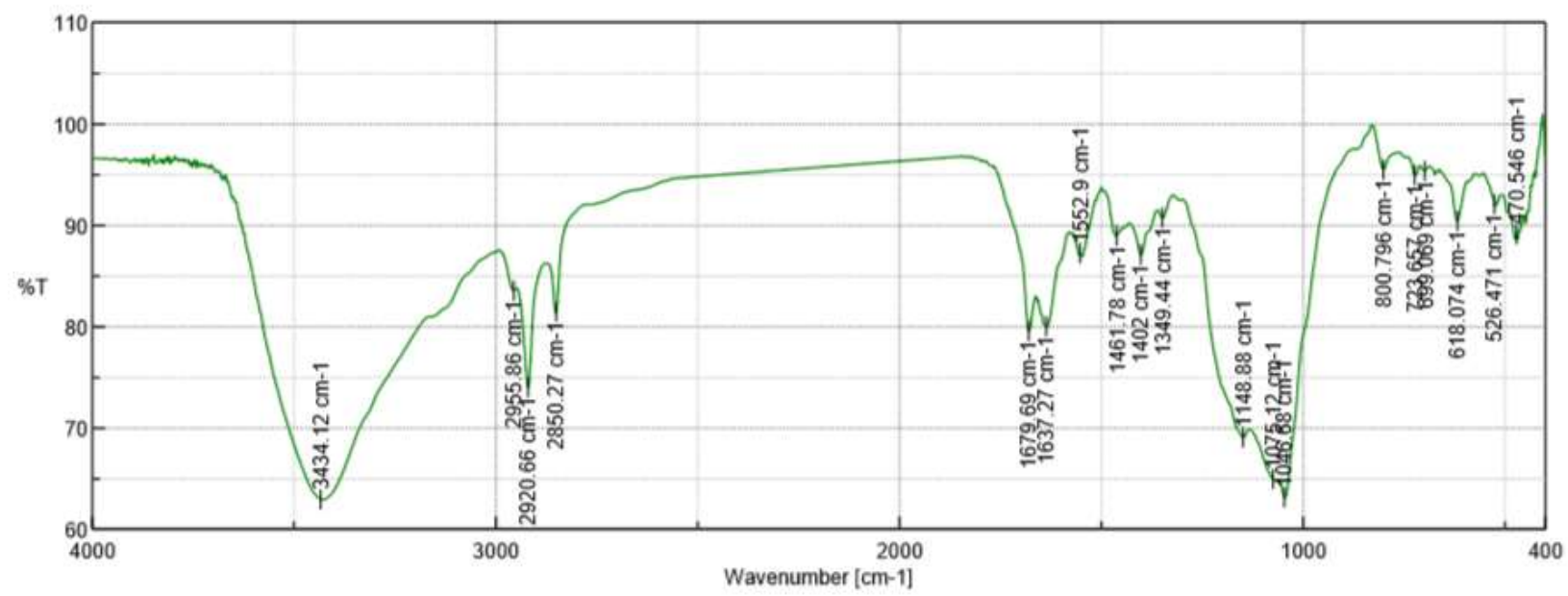

Figure S25. IR spectrum of ireneamide A (6).

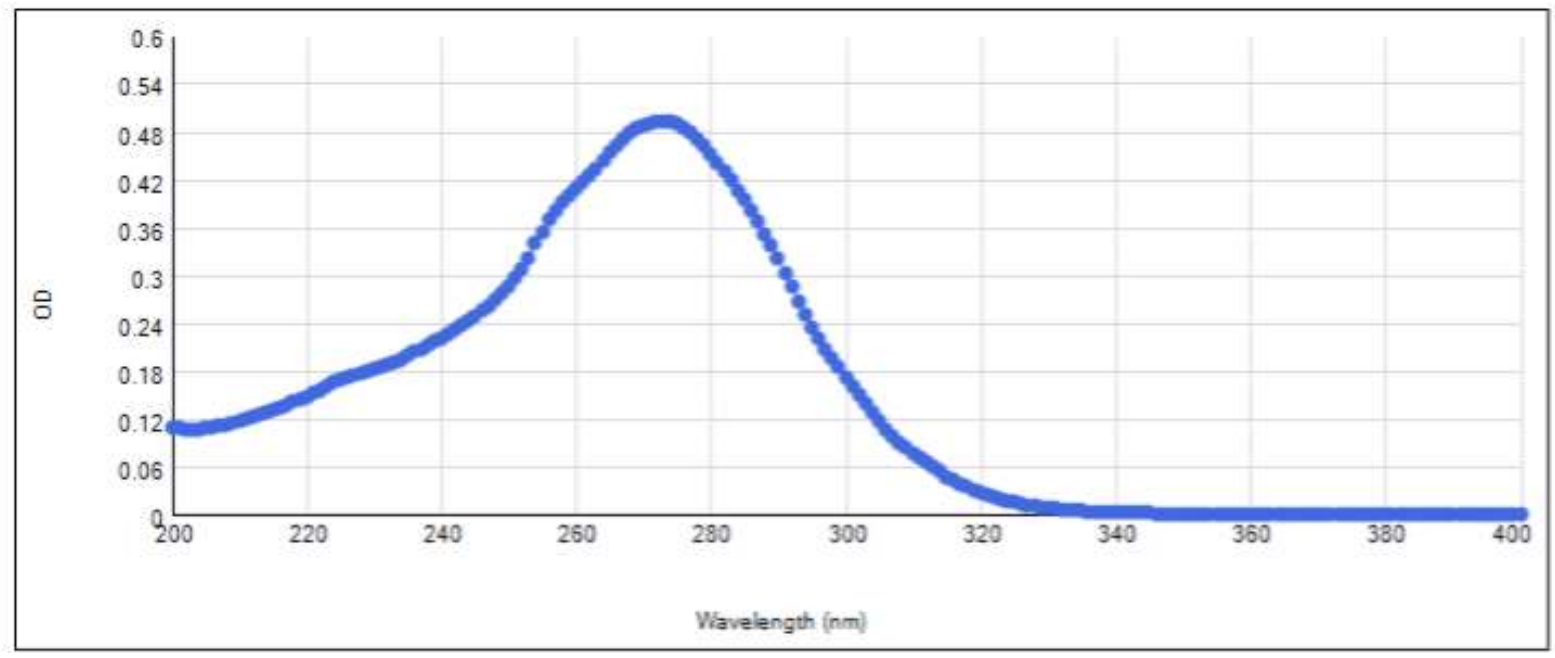

Figure S26. UV spectrum of ireneamide A (6). 
Table S4. NMR data $\left({ }^{1} \mathrm{H}: 400 \mathrm{MHz},{ }^{13} \mathrm{C} 100 \mathrm{MHz}\right)$ for ireneamide A (6).

\begin{tabular}{cccccc} 
position & $\delta_{\mathrm{C}}$ & $\delta_{\mathrm{H}}$ mult. $(\mathrm{J}$ in Hz$)$ & COSY & HMBC & NOESY \\
\hline $1-\mathrm{Me}$ & $37.3, \mathrm{CH}_{3}$ & $3.72, \mathrm{~s}$ & & 2,5 & 2,5 \\
2 & $138.2, \mathrm{CH}$ & $8.51, \mathrm{~s}$ & & 4,5 & $1-\mathrm{Me}$ \\
4 & $131.1, \mathrm{C}$ & & & & \\
5 & $125.2, \mathrm{CH}$ & $7.51, \mathrm{~s}$ & & 2,4 & $1,6,7$ \\
6 & $126.6, \mathrm{CH}$ & $7.17, \mathrm{~d}(16)$ & 7 & $4,5,8$ & 5,7 \\
7 & $125.0, \mathrm{CH}$ & $6.45, \mathrm{~d}(16)$ & 6 & 4,8 & 5,6 \\
8 & $168.5, \mathrm{C}$ & & & & \\
10 & $37.0, \mathrm{CH}_{2}$ & $3.51, \mathrm{t}(6.6)$ & 11 & 8,11 & 11 \\
11 & $51.1, \mathrm{CH}_{2}$ & $2.95, \mathrm{t}(6.6)$ & 10 & 10 & 10 \\
\hline
\end{tabular}

Measured at $303 \mathrm{~K}$ in $\mathrm{D}_{2} \mathrm{O}$ with $10 \mu \mathrm{L}$ DMSO- $d_{6}$ as internal standard $\left(\delta_{\mathrm{H}} 2.49\right.$, $\left.\delta_{\mathrm{C}} 39.5 \mathrm{ppm}\right)$.

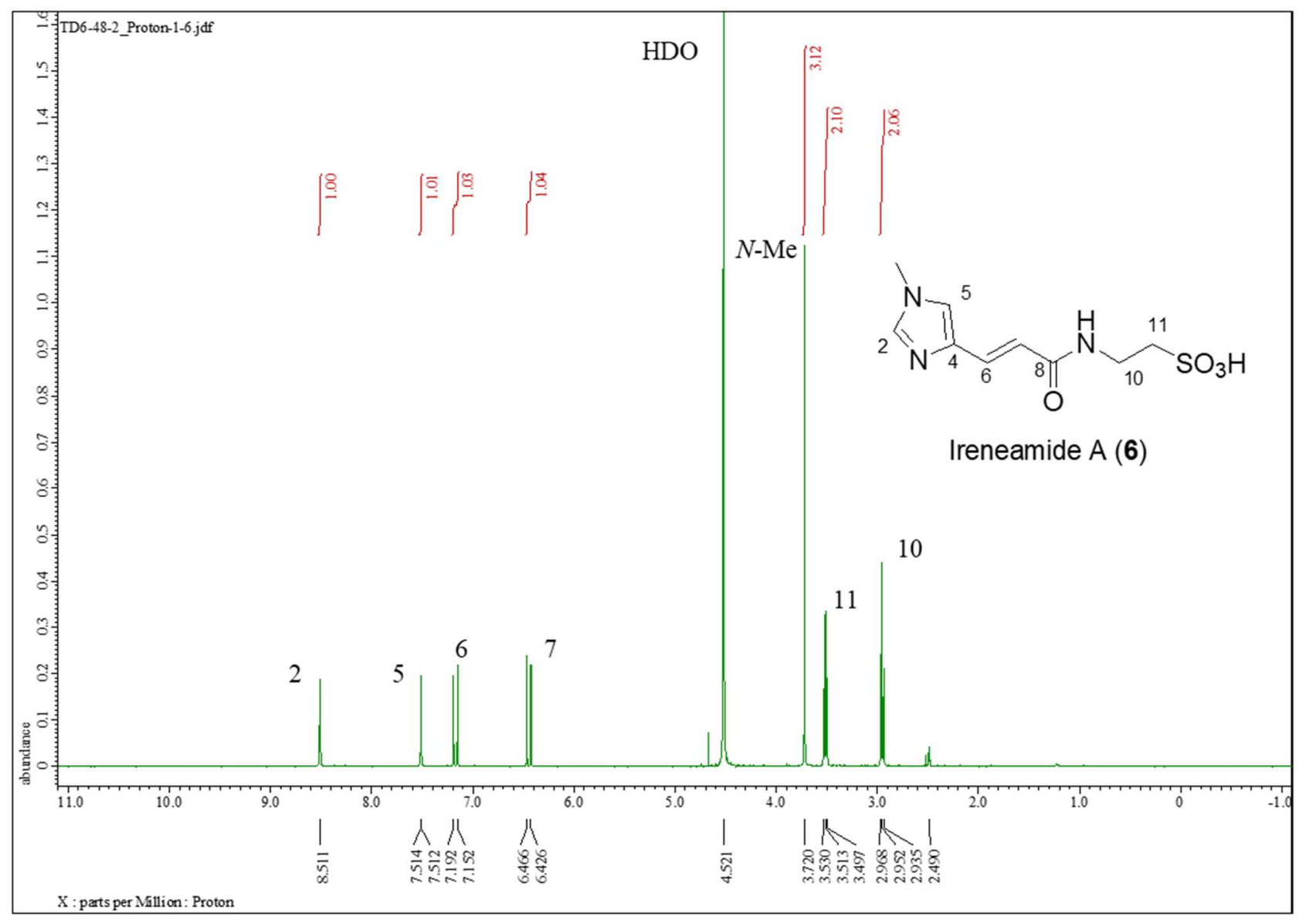

Figure S27. ${ }^{1} \mathrm{H}$ NMR spectrum of ireneamide $\mathrm{A}(\mathbf{6})$ in $\mathrm{D}_{2} \mathrm{O}$ with $10 \mu \mathrm{L}$ DMSO- $d_{6}(400 \mathrm{MHz})$. 


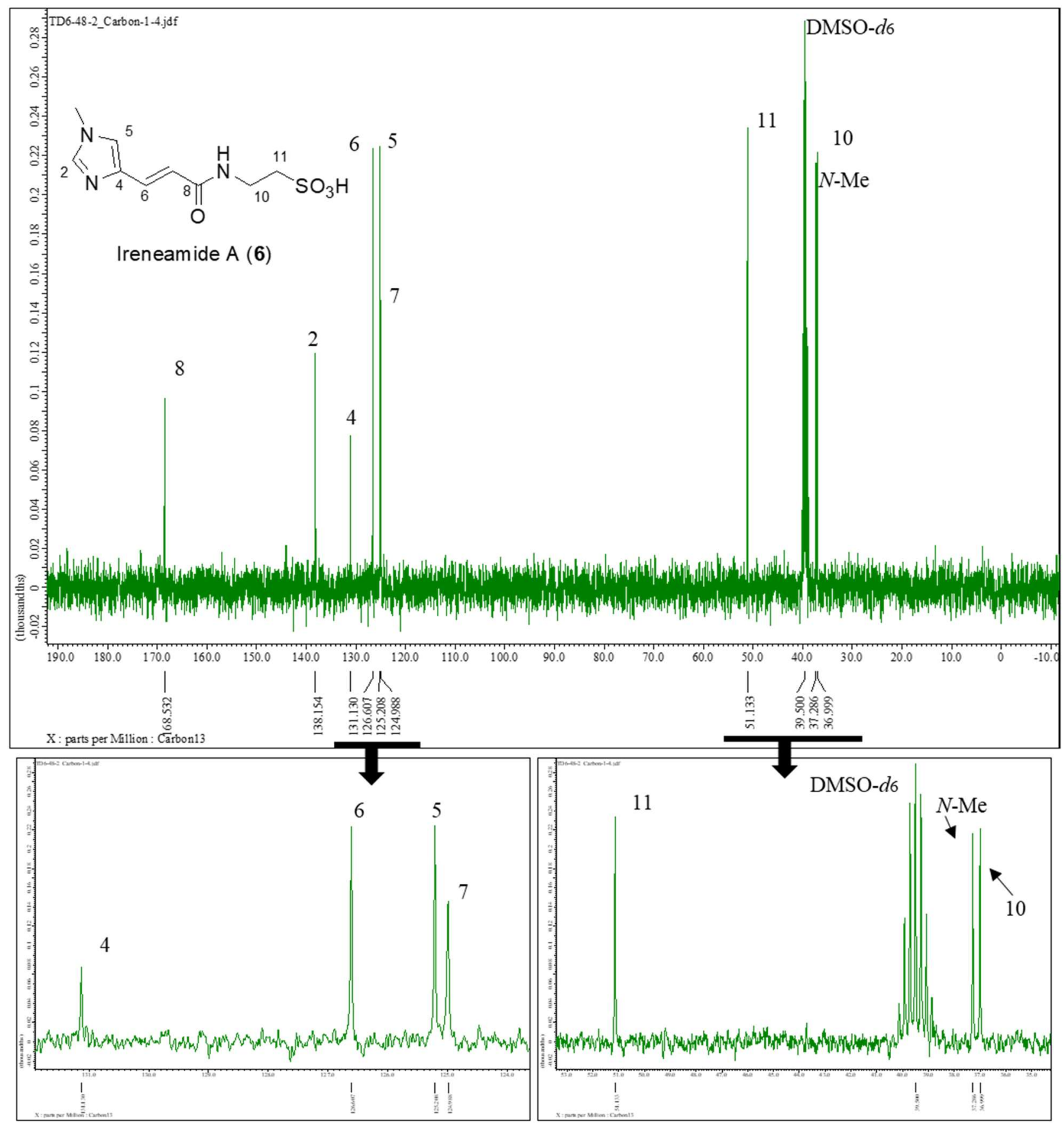

Figure S28. ${ }^{13} \mathrm{C}$ NMR spectrum of ireneamide $\mathrm{A}(6)$ in $\mathrm{D}_{2} \mathrm{O}$ with $10 \mu \mathrm{L}$ DMSO- $d_{6}(100 \mathrm{MHz})$. 


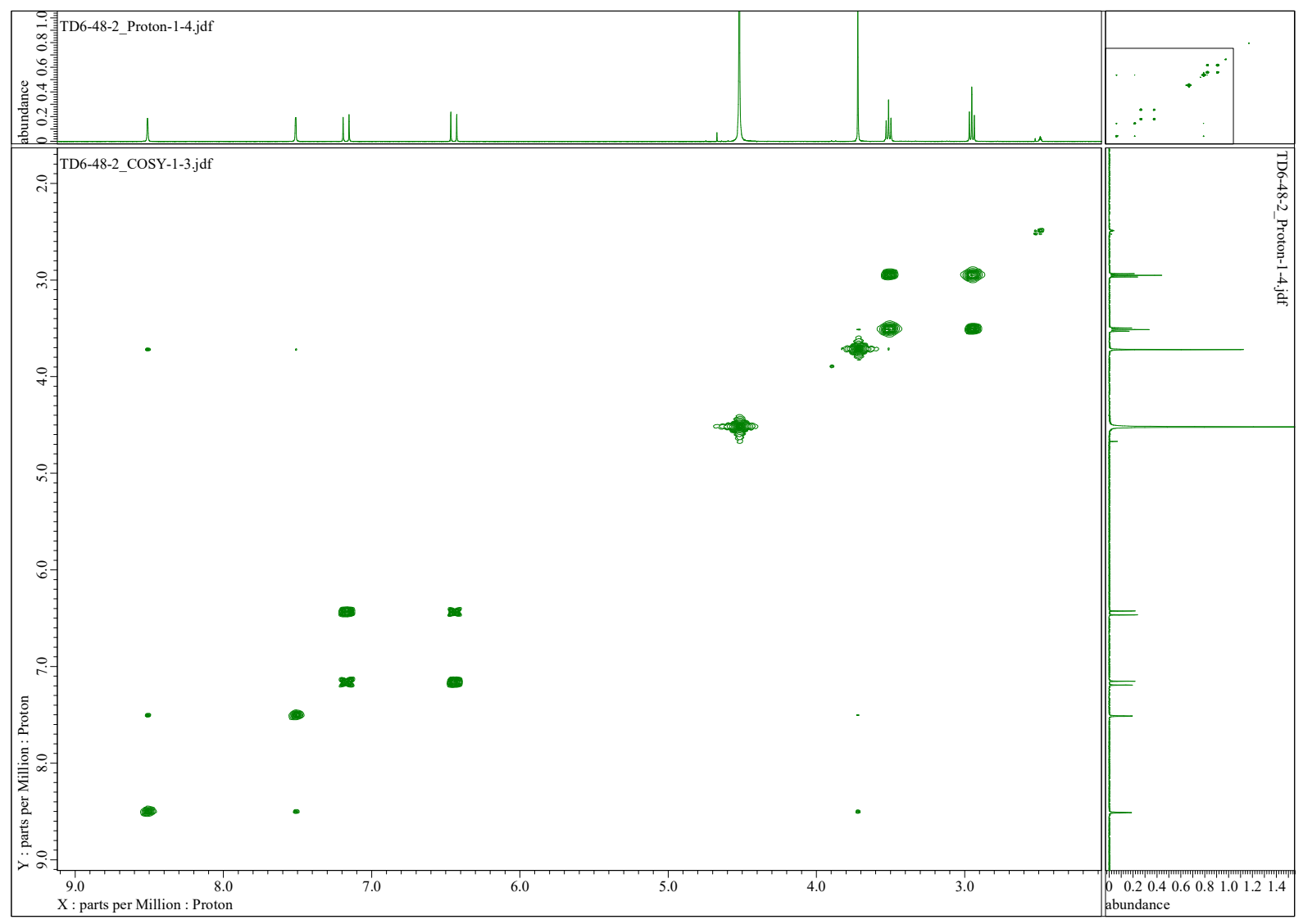

Figure S29. COSY spectrum of ireneamide A (6) in $\mathrm{D}_{2} \mathrm{O}$ with $10 \mu \mathrm{L}$ DMSO- $d_{6}$.

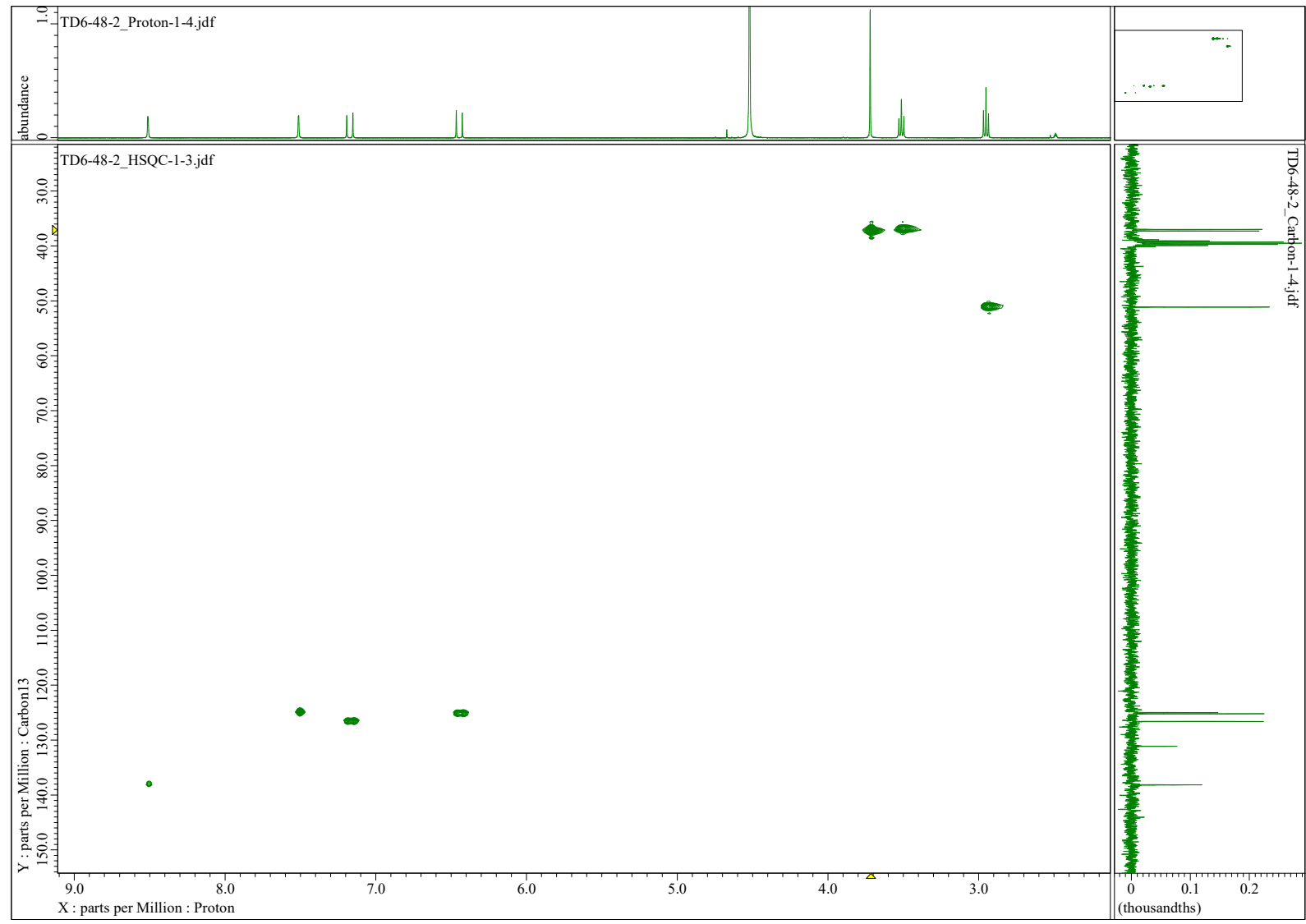

Figure S30. HSQC spectrum of ireneamide A (6) in $\mathrm{D}_{2} \mathrm{O}$ with $10 \mu \mathrm{L}$ DMSO- $d_{6}$. 


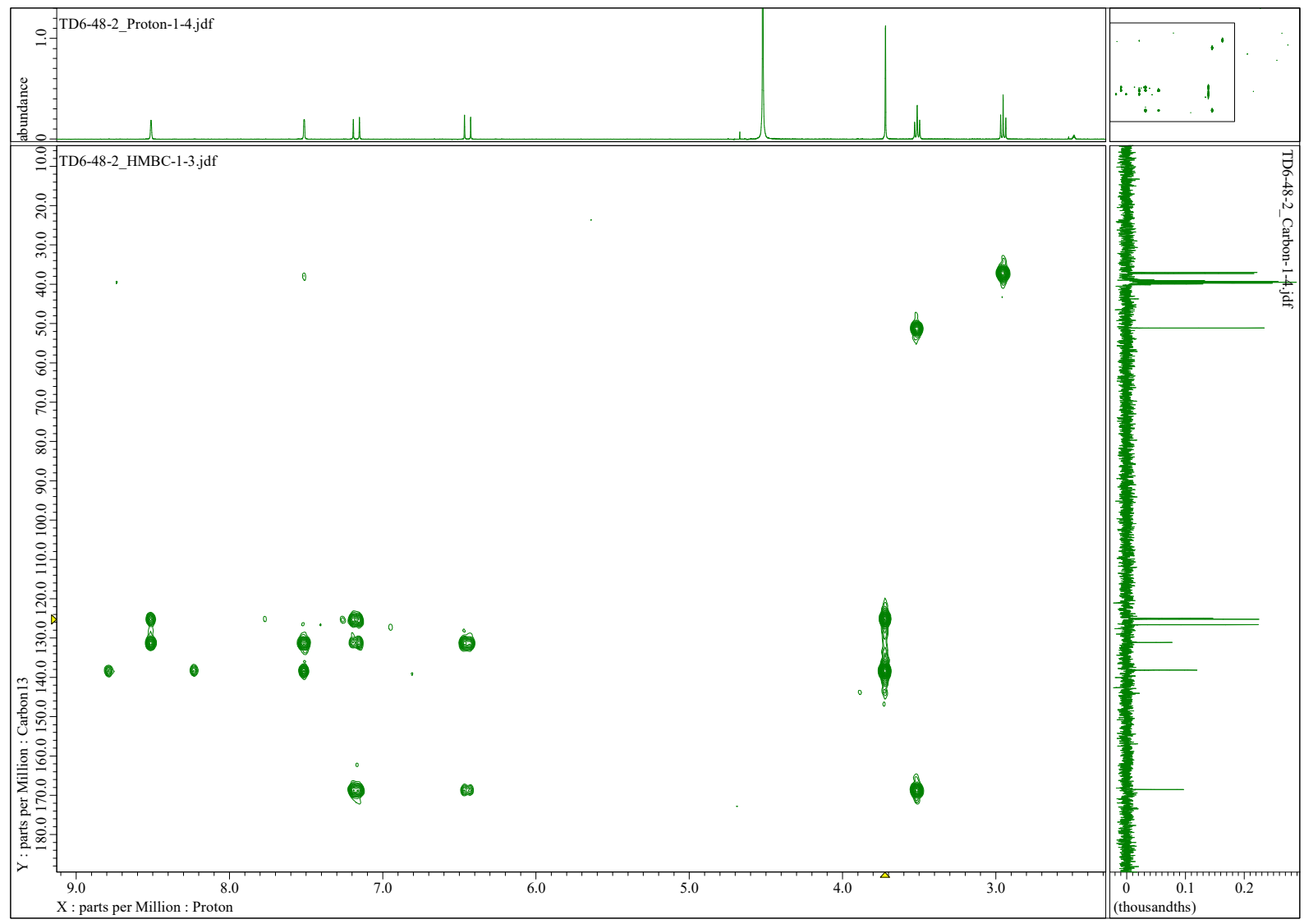

Figure S31. HMBC spectrum of ireneamide A (6) in $\mathrm{D}_{2} \mathrm{O}$ with $10 \mu \mathrm{L} \mathrm{DMSO}-d_{6}$.

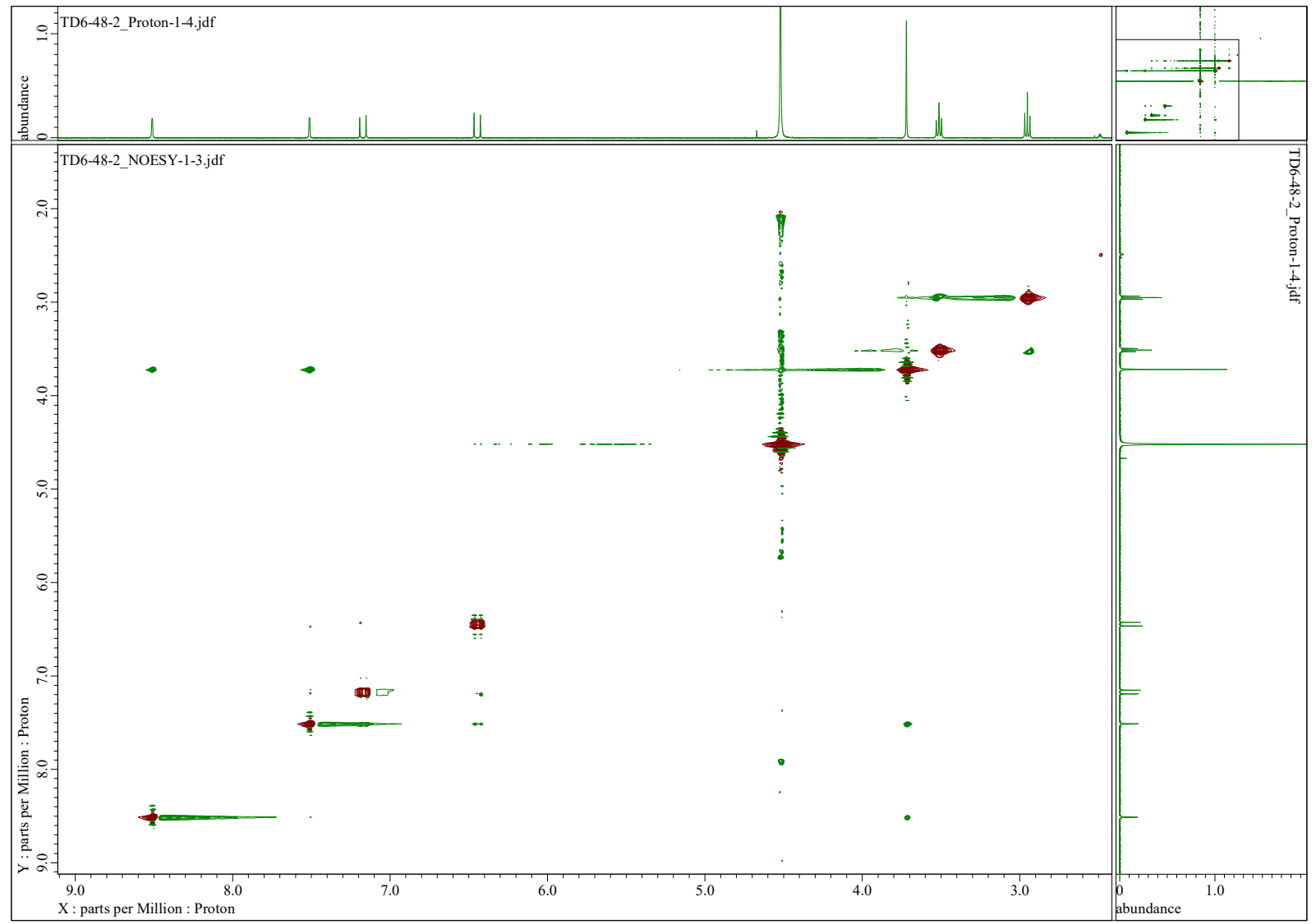

Figure S32. NOESY spectrum of ireneamide A (6) in $\mathrm{D}_{2} \mathrm{O}$ with $10 \mu \mathrm{L}$ DMSO- $d_{6}$. 
3.2. Spectral data and NMR assignments for ireneamide B (7).

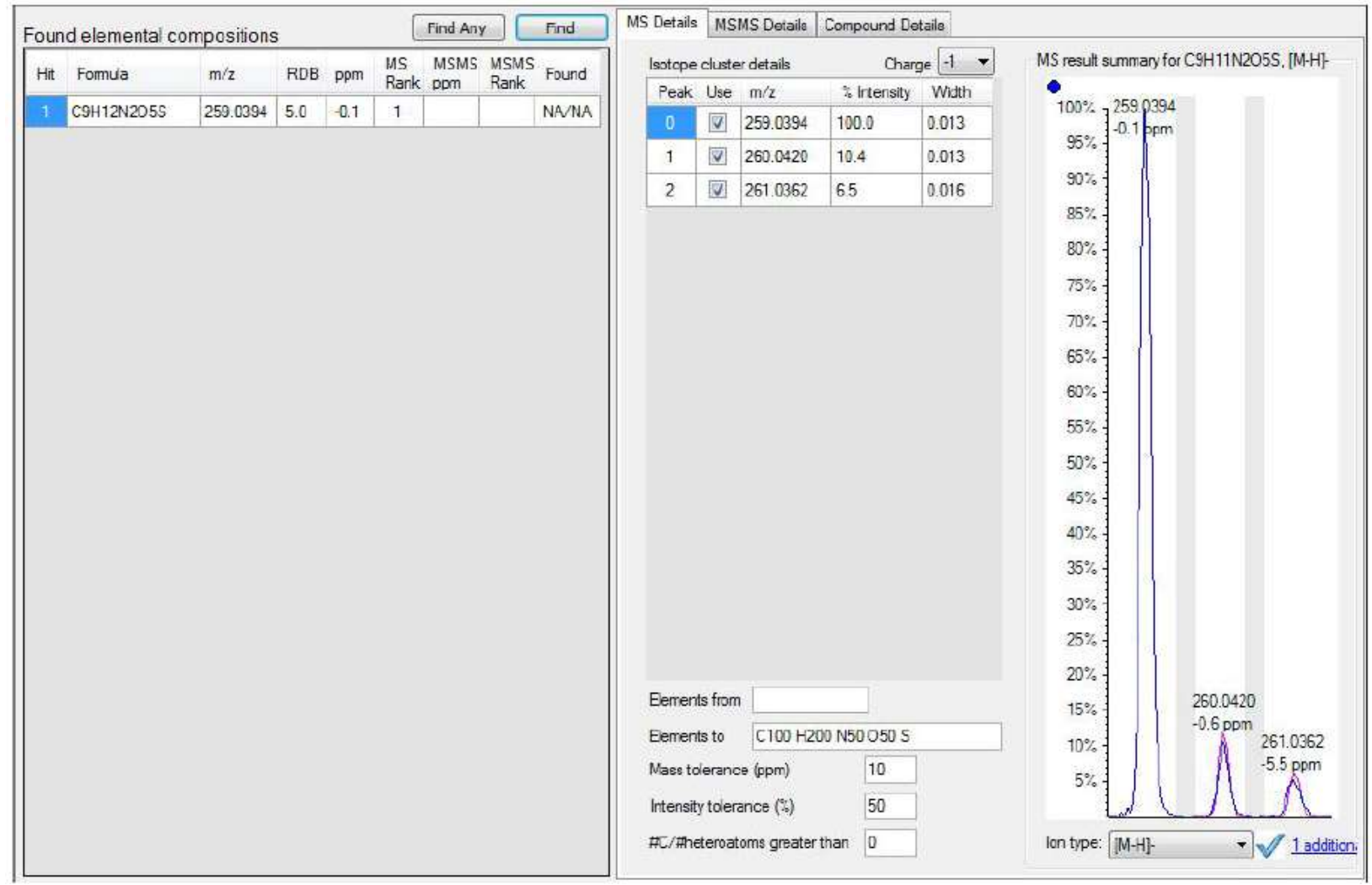

Figure S33. HRESIMS data for ireneamide B (7).

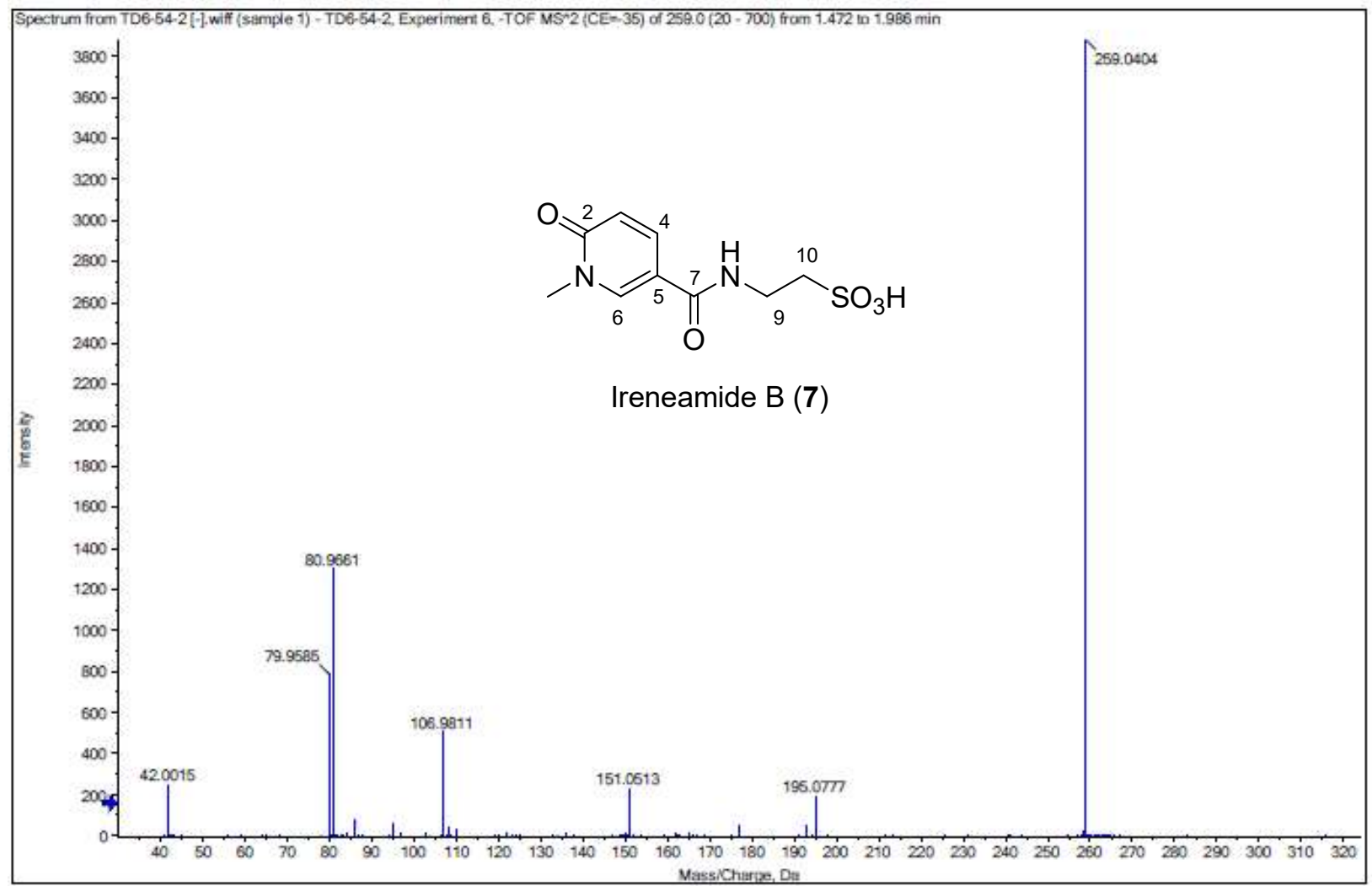

Figure S34. HRESI MS/MS spectrum of ireneamide B (7). Collision Energy (CE) -35V. 


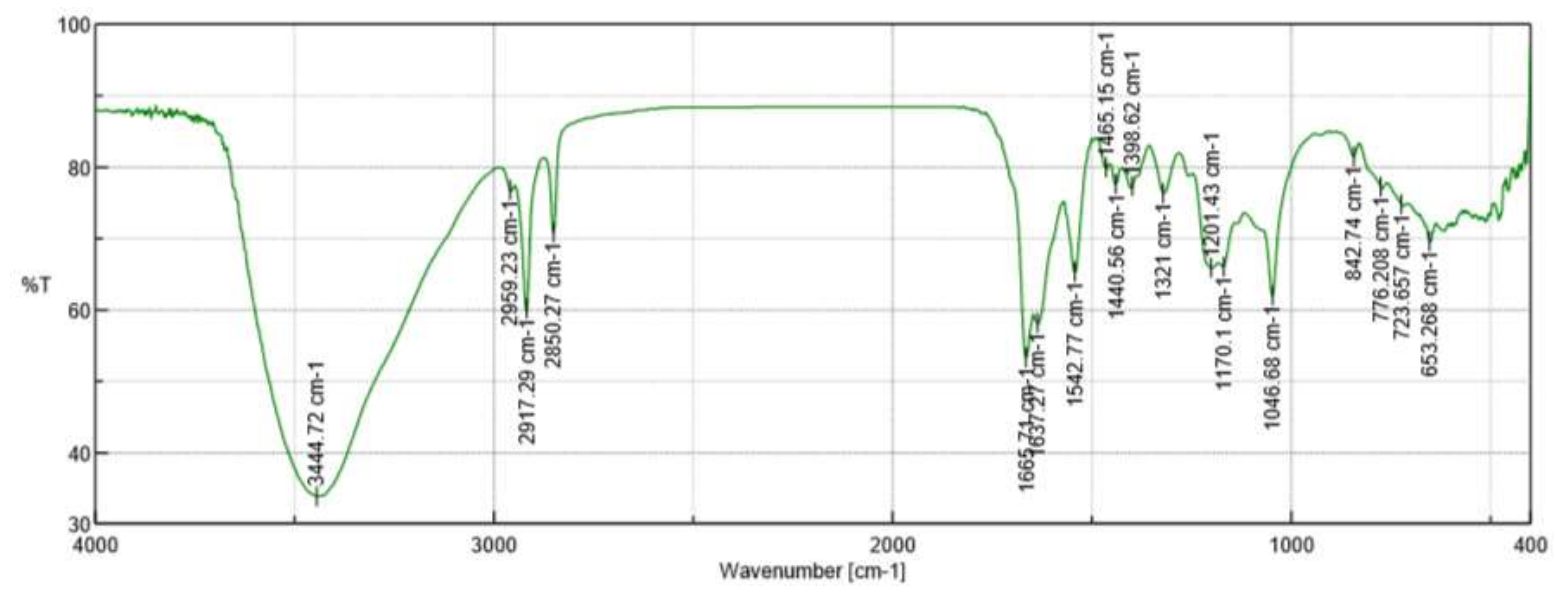

Figure S35. IR spectrum of ireneamide B (7).

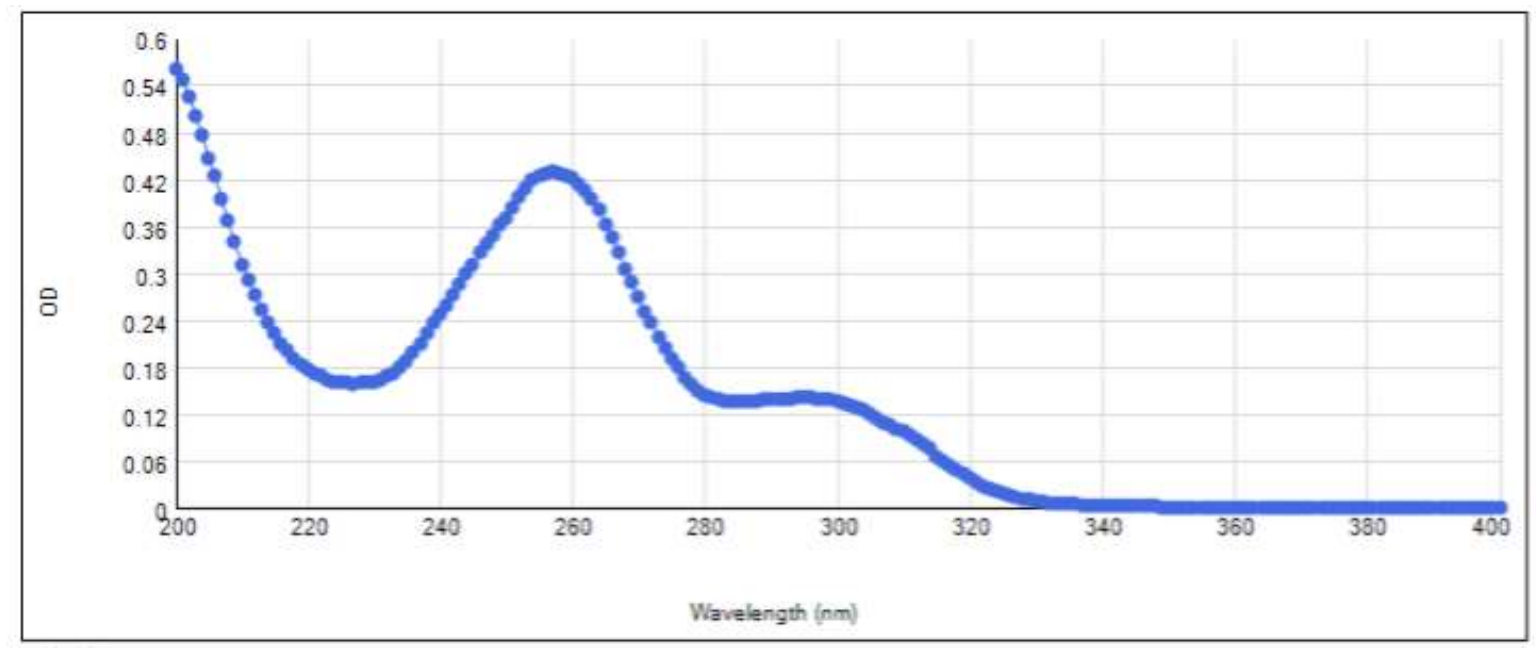

Figure S36. UV spectrum of ireneamide B (7).

Table S5. NMR ( $\left.{ }^{1} \mathrm{H}: 400 \mathrm{MHz},{ }^{13} \mathrm{C}: 100 \mathrm{MHz}\right)$ data of ireneamide B (7).

\begin{tabular}{ccccccc}
$\# \mathrm{C}$ & $\delta_{\mathrm{C}}$ & $\delta_{\mathrm{H}}$ mult. $(J$ in Hz) & $\delta_{\mathrm{H}}$ mult. $(J \text { in Hz })^{a}$ & COSY & HMBC & NOESY \\
\hline $1-\mathrm{Me}$ & $39.6, \mathrm{CH}_{3}$ & $3.63, \mathrm{~s}$ & $3.46, \mathrm{~s}$ & & 2,6 & 6 \\
2 & $166.0, \mathrm{C}$ & & & & & \\
3 & $119.3, \mathrm{CH}$ & $6.65, \mathrm{~d}(9.2)$ & $6.38, \mathrm{~d}(9.6)$ & 4 & 5 & 3,8 \\
4 & $140.2, \mathrm{CH}$ & $7.91, \mathrm{dd}(9.6,2.4)$ & $7.74, \mathrm{dd}(9.6,2.7)$ & 3,6 & 2,6 & 3,8 \\
5 & $116.2, \mathrm{C}$ & & & & & \\
6 & $143.0, \mathrm{CH}$ & $8.25, \mathrm{~d}(2.4)$ & $8.28, \mathrm{~d}(2.7)$ & 4 & 2,4 & $1-\mathrm{Me}, 8$ \\
7 & $167.7, \mathrm{C}$ & & 8.22, brt & 9 & & $4,6,9,10$ \\
$8-\mathrm{NH}^{a}$ & & & $3.45^{b}$, overlap & $8^{a}, 10$ & 7,10 & $8^{a}, 10$ \\
9 & $36.7, \mathrm{CH}_{2}$ & $3.74, \mathrm{t}(6.7)$ & $2.62, \mathrm{t}(7.8,6.9)$ & 9 & 9 & $8^{a}, 9$ \\
10 & $50.6, \mathrm{CH}_{2}$ & $3.17, \mathrm{t}(6.7)$ & & & & \\
\hline
\end{tabular}

Measured at $303 \mathrm{~K}$ in $\mathrm{D}_{2} \mathrm{O}$ with $10 \mu \mathrm{L} \mathrm{CD}{ }_{3} \mathrm{OD}$ as internal standard $\left(\delta_{\mathrm{H}} 3.30, \delta_{\mathrm{C}} 49.15 \mathrm{ppm}\right) .{ }^{a}$ Measured at 303

$\mathrm{K}$ in DMSO- $d_{6 .}{ }^{b} \mathrm{Chemical}$ shift determined from COSY spectrum. 


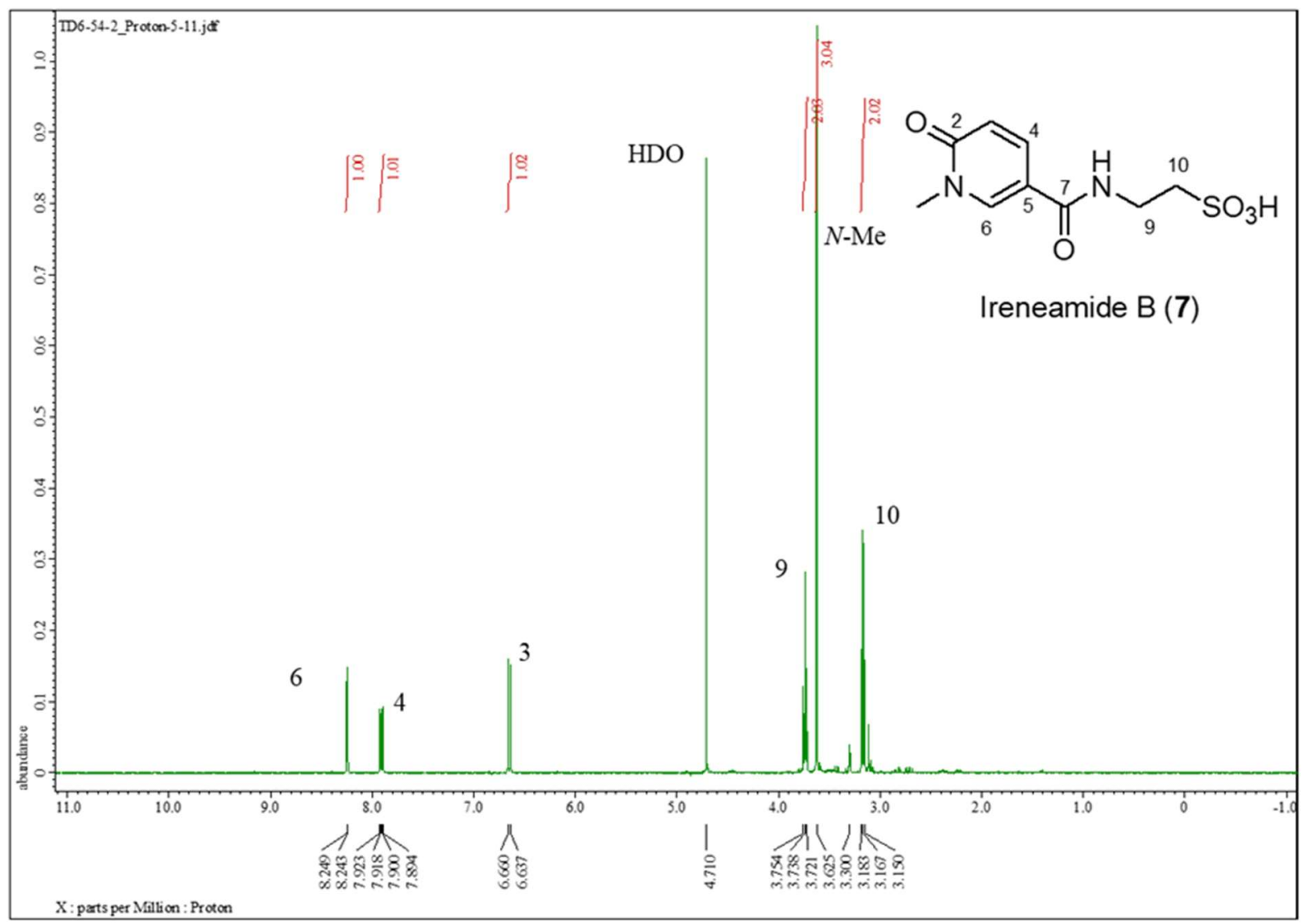

Figure S37. ${ }^{1} \mathrm{H}$ NMR spectrum of ireneamide B (7) in $\mathrm{D}_{2} \mathrm{O}$ with $10 \mu \mathrm{L} \mathrm{CD}_{3} \mathrm{OD}(400 \mathrm{MHz})$.

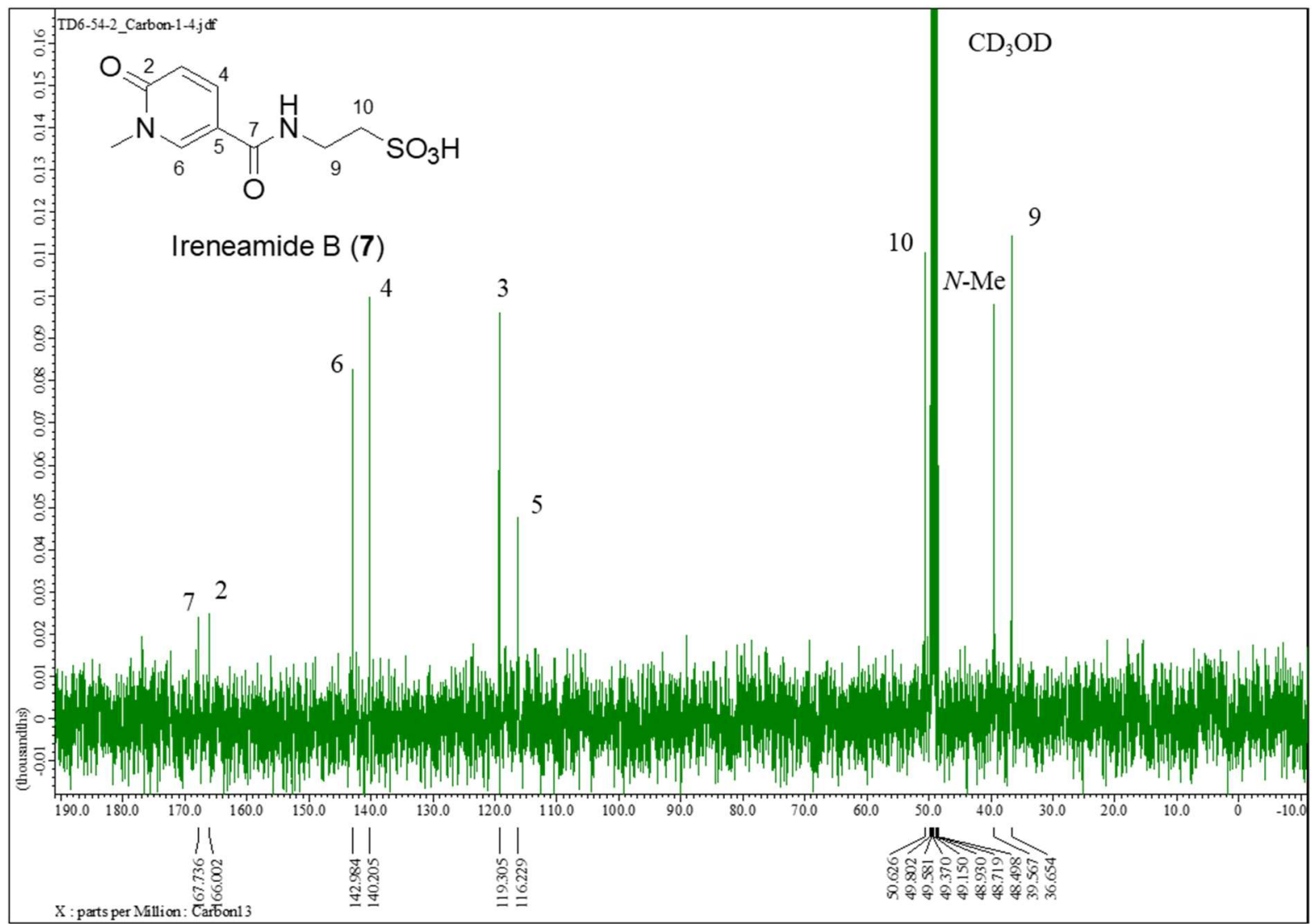

Figure S38. ${ }^{13} \mathrm{C}$ NMR spectrum of ireneamide B (7) in $\mathrm{D}_{2} \mathrm{O}$ with $10 \mu \mathrm{L} \mathrm{CD}_{3} \mathrm{OD}(100 \mathrm{MHz})$. 


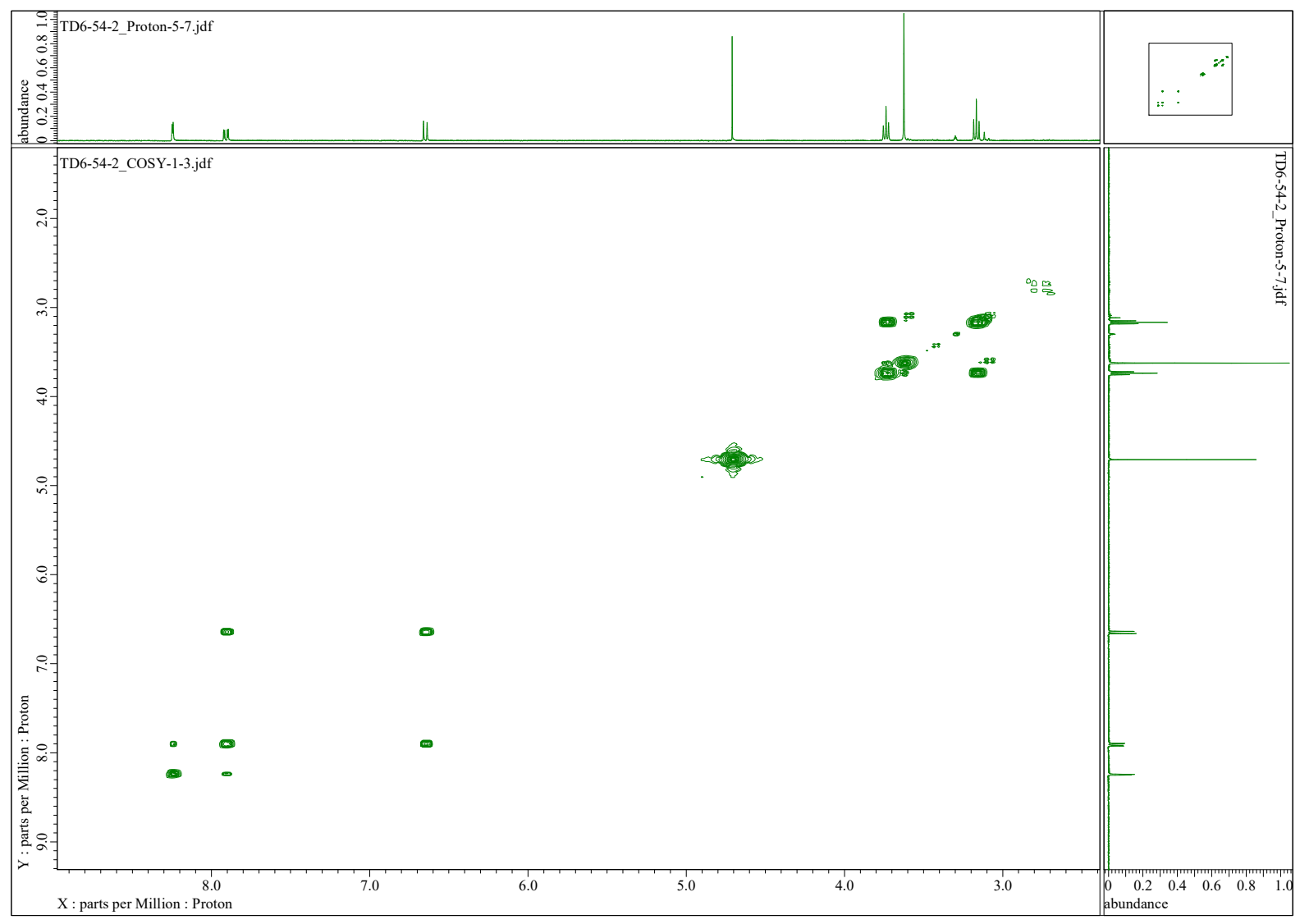

Figure S39. COSY spectrum of ireneamide B (7) in $\mathrm{D}_{2} \mathrm{O}$ with $10 \mu \mathrm{L} \mathrm{CD}_{3} \mathrm{OD}$.

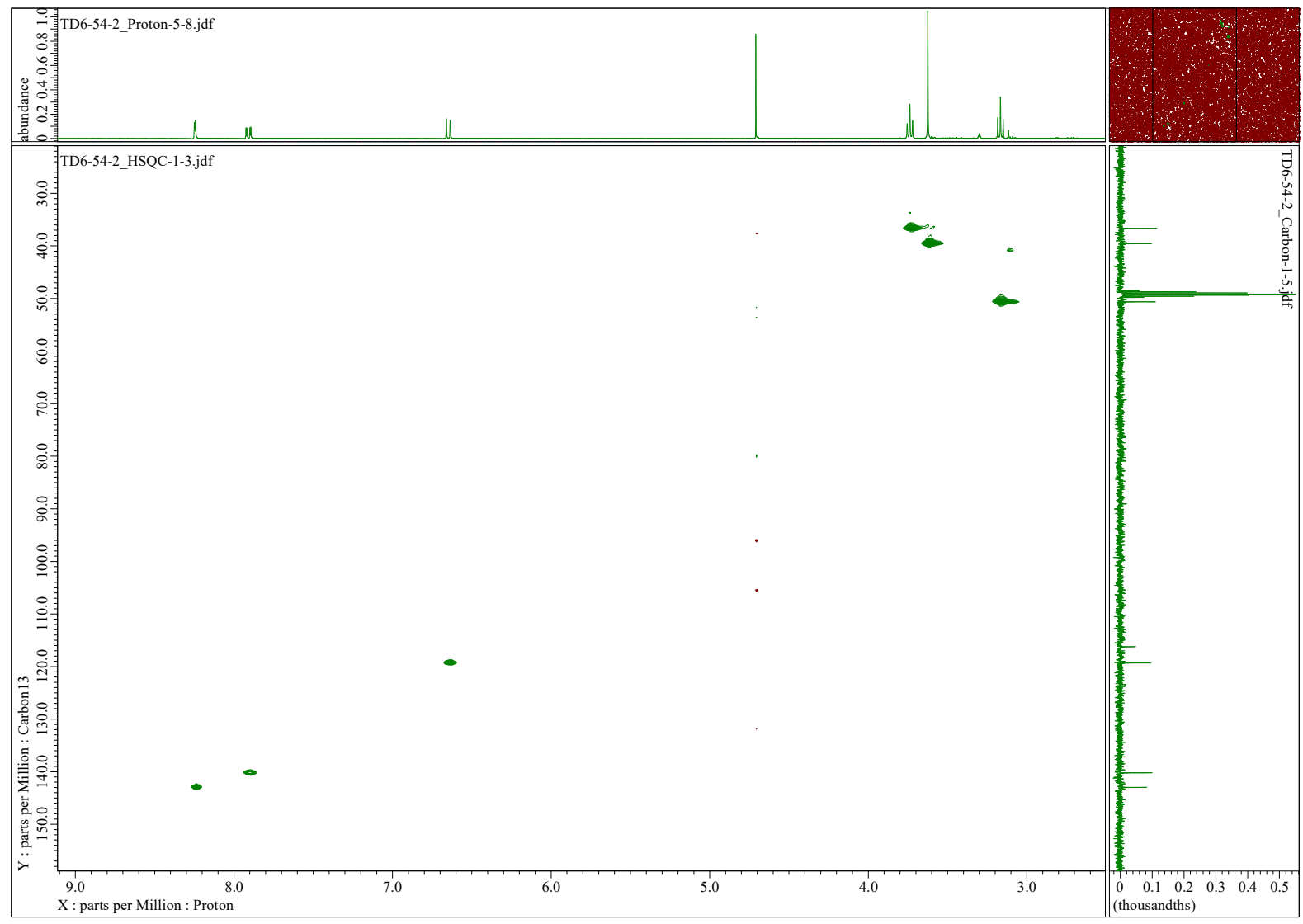

Figure S40. HSQC spectrum of ireneamide B (7) in $\mathrm{D}_{2} \mathrm{O}$ with $10 \mu \mathrm{L} \mathrm{CD}_{3} \mathrm{OD}$. 


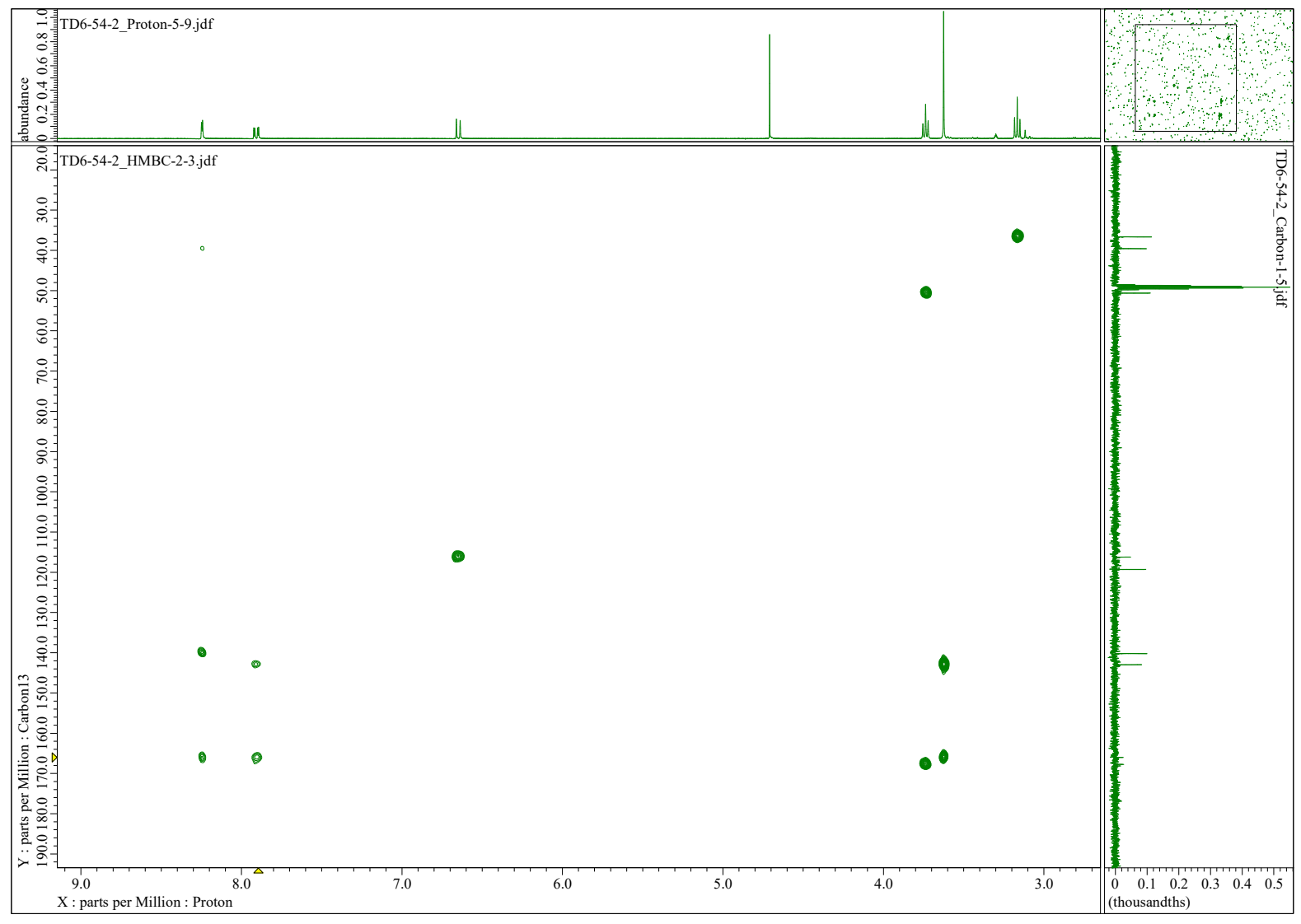

Figure S41. HMBC spectrum of ireneamide B (7) in $\mathrm{D}_{2} \mathrm{O}$ with $10 \mu \mathrm{LCD}_{3} \mathrm{OD}$.

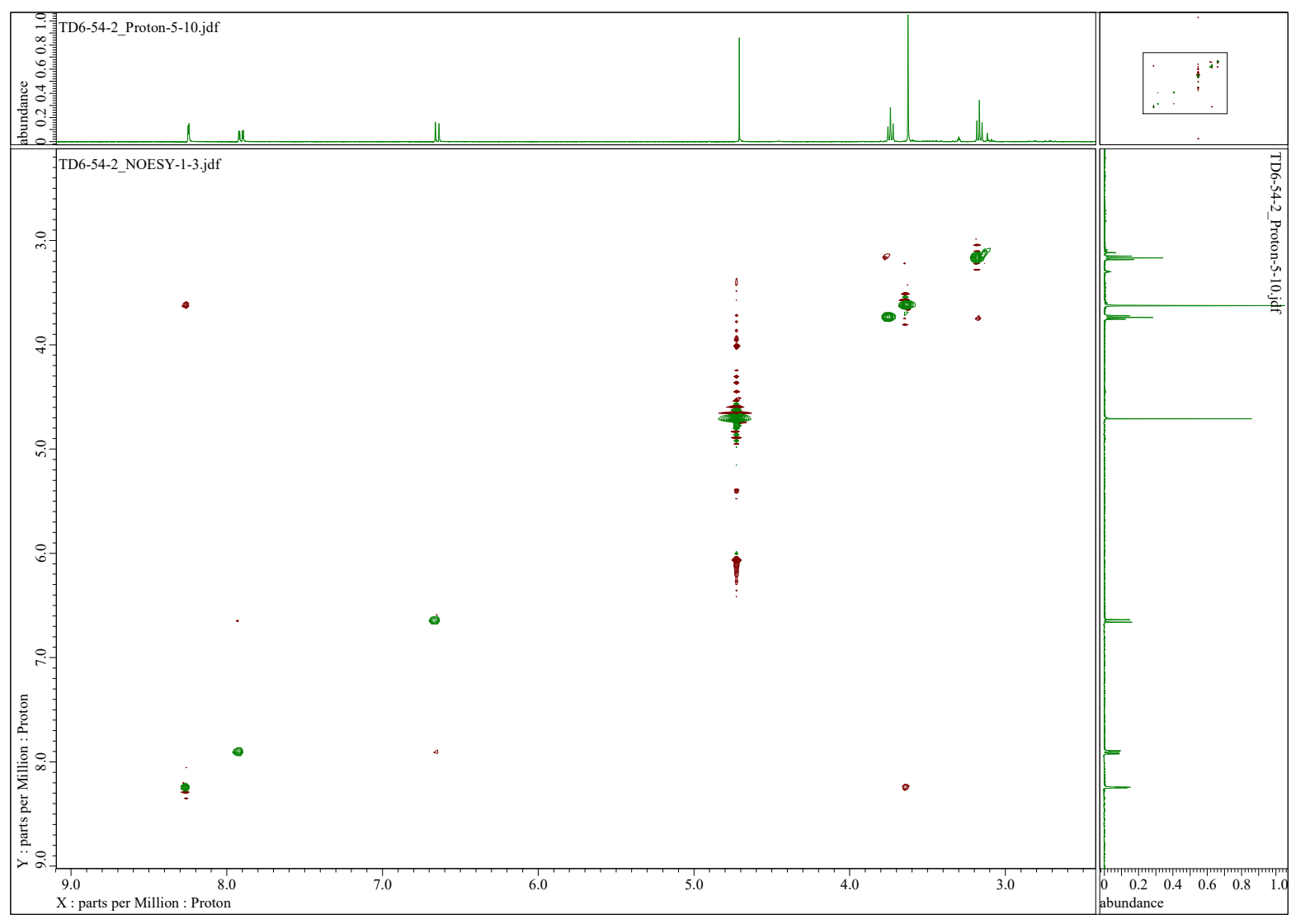

Figure S42. NOESY spectrum of ireneamide $\mathrm{B}(7)$ in $\mathrm{D}_{2} \mathrm{O}$ with $10 \mu \mathrm{LCD}_{3} \mathrm{OD}$. 


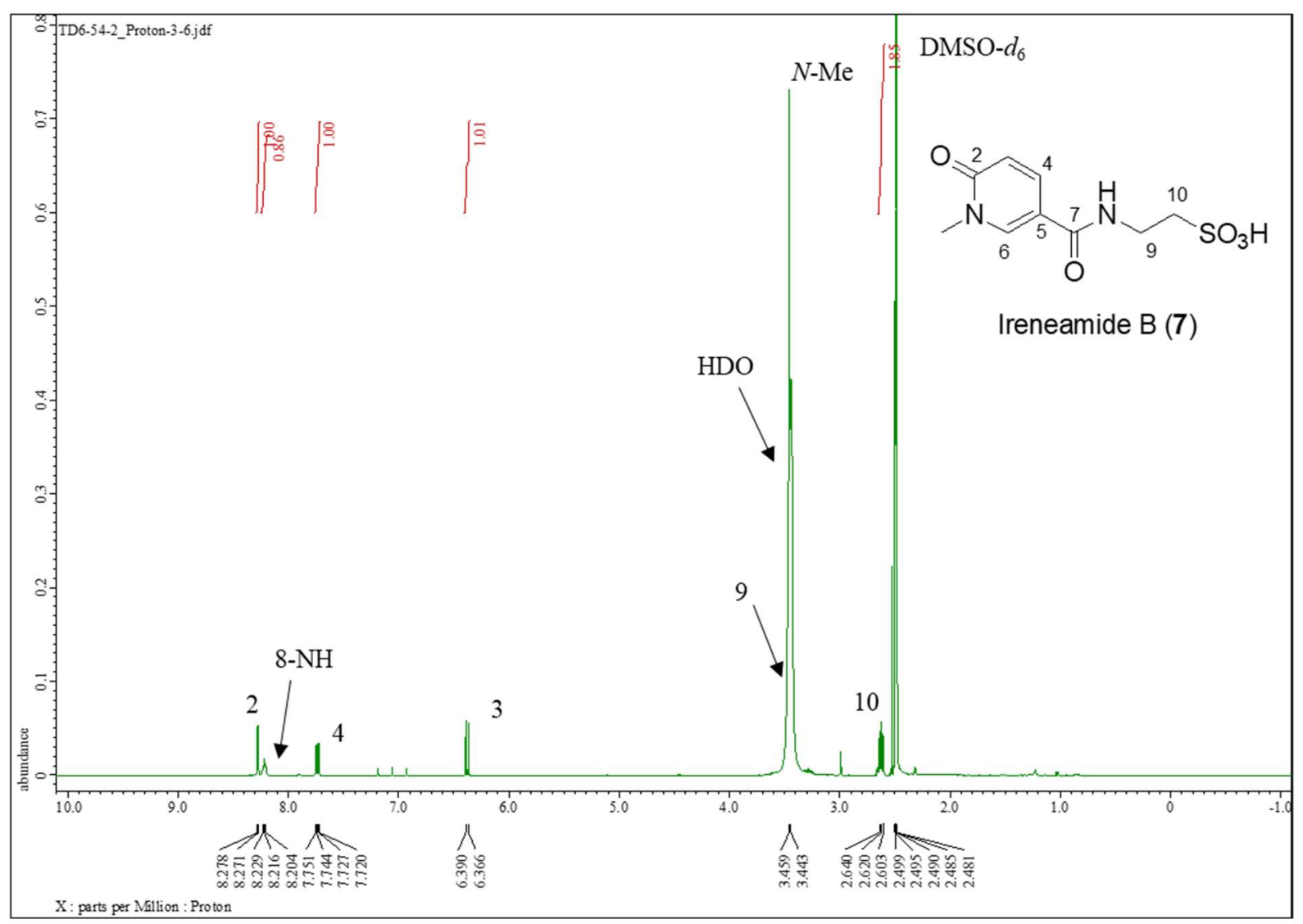

Figure S43. ${ }^{1} \mathrm{H}$ NMR spectrum of ireneamide B (7) in DMSO- $d_{6}(400 \mathrm{MHz})$.

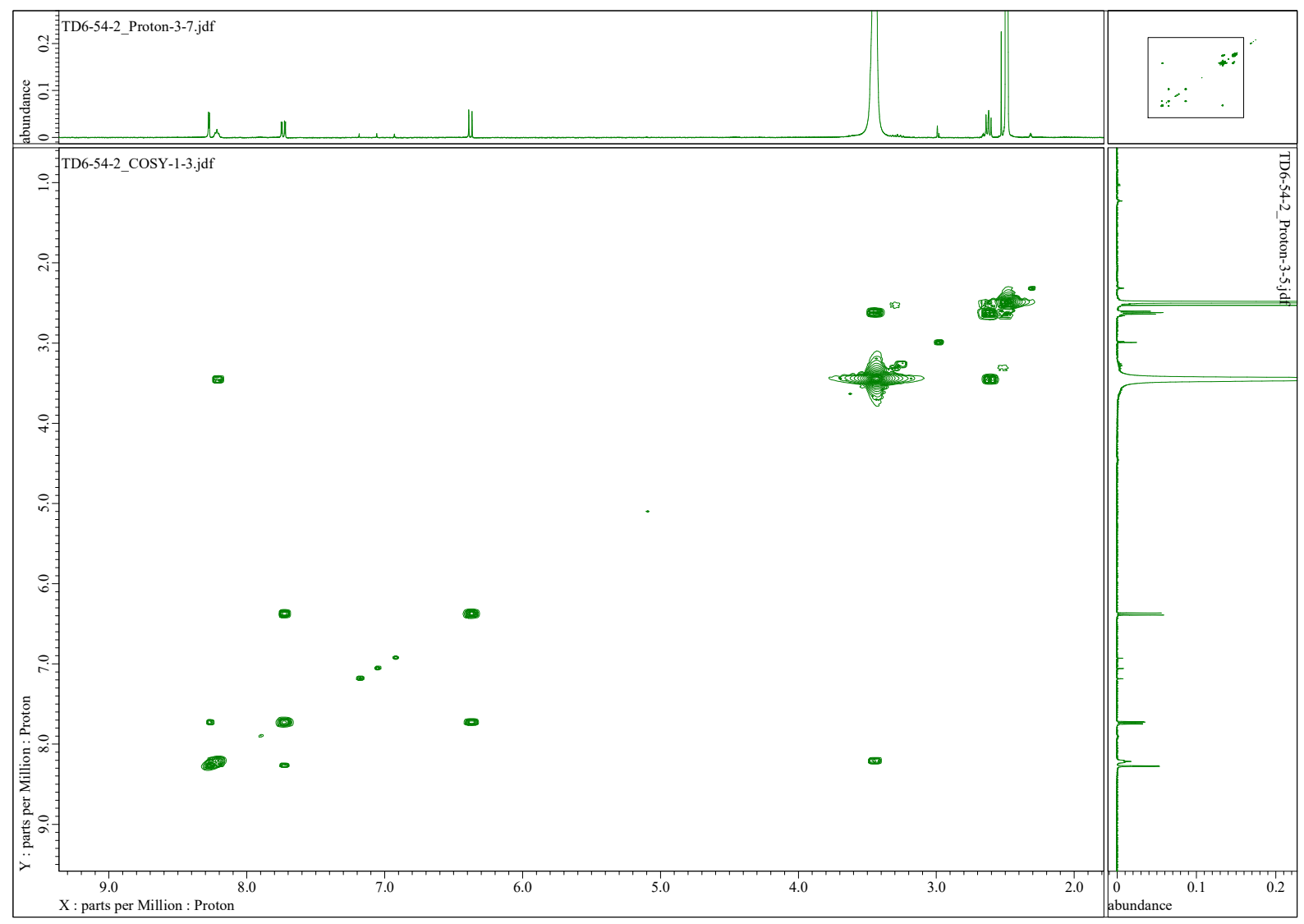

Figure S44. COSY spectrum of ireneamide B (7) in DMSO- $d_{6}$. 


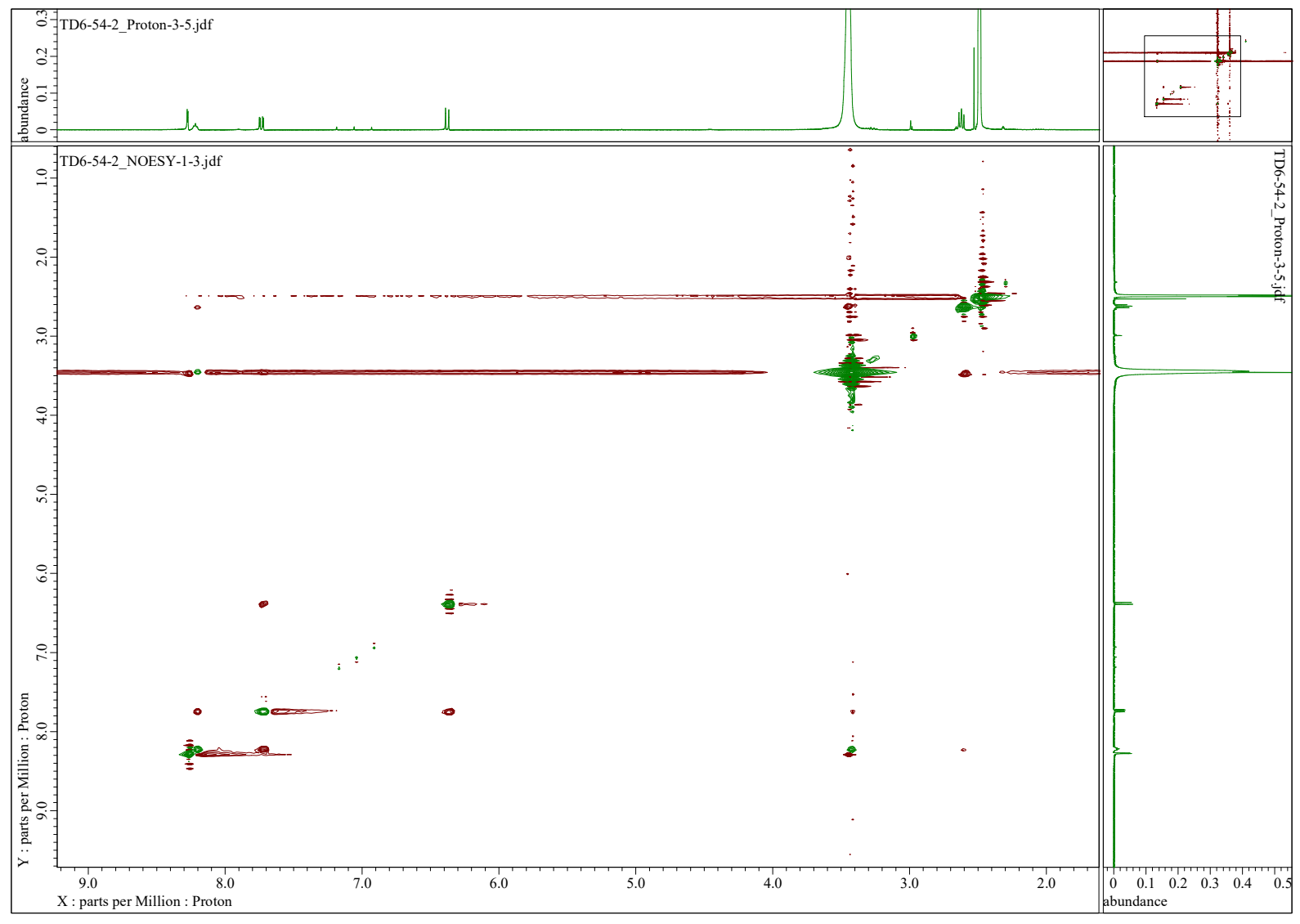

Figure S45. NOESY spectrum of ireneamide B (7) in DMSO- $d_{6}$. 
3.3. Spectral data and NMR assignments for ireneamide C (8).

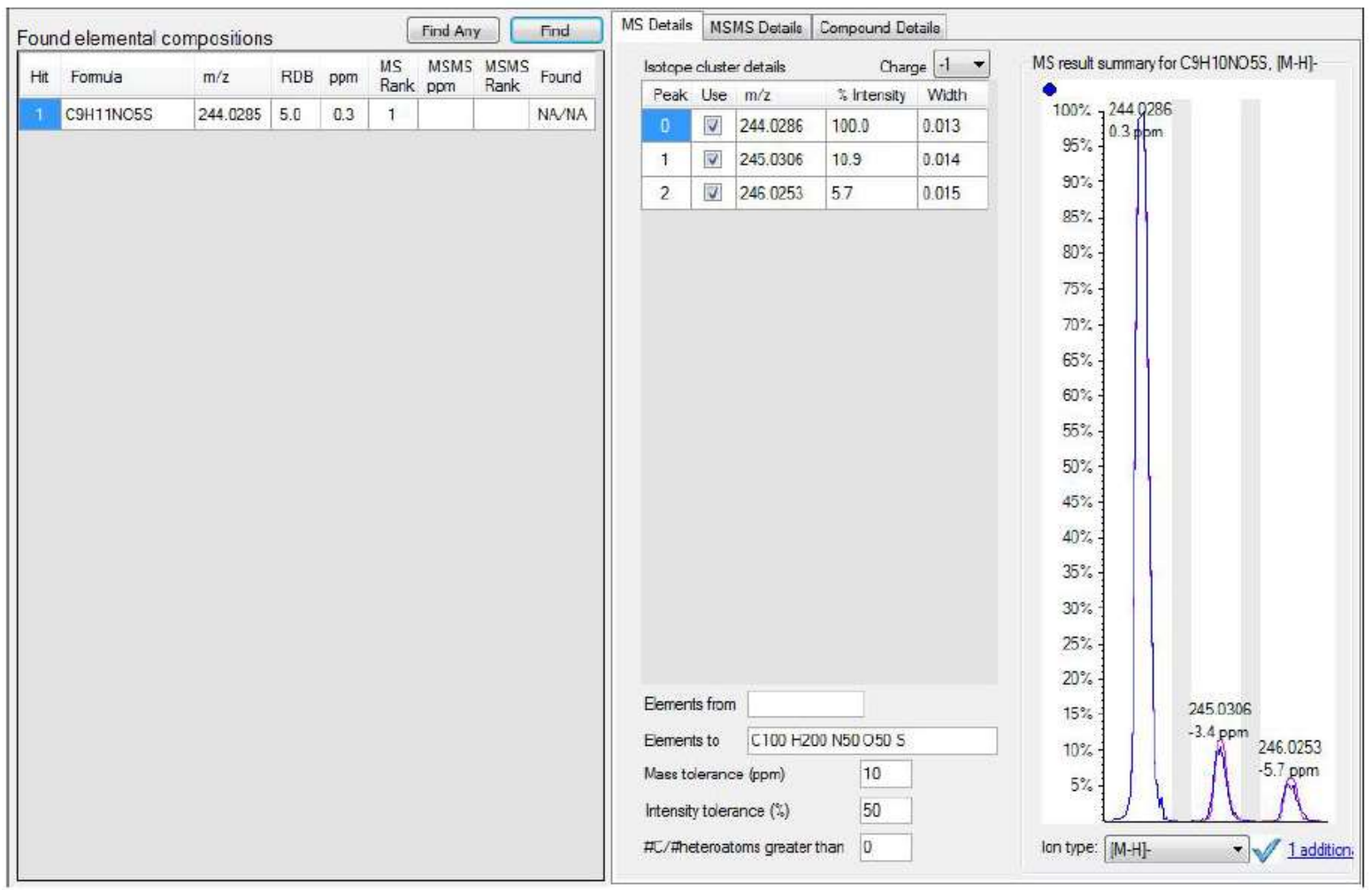

Figure S46. HRESIMS data for ireneamide C (8).

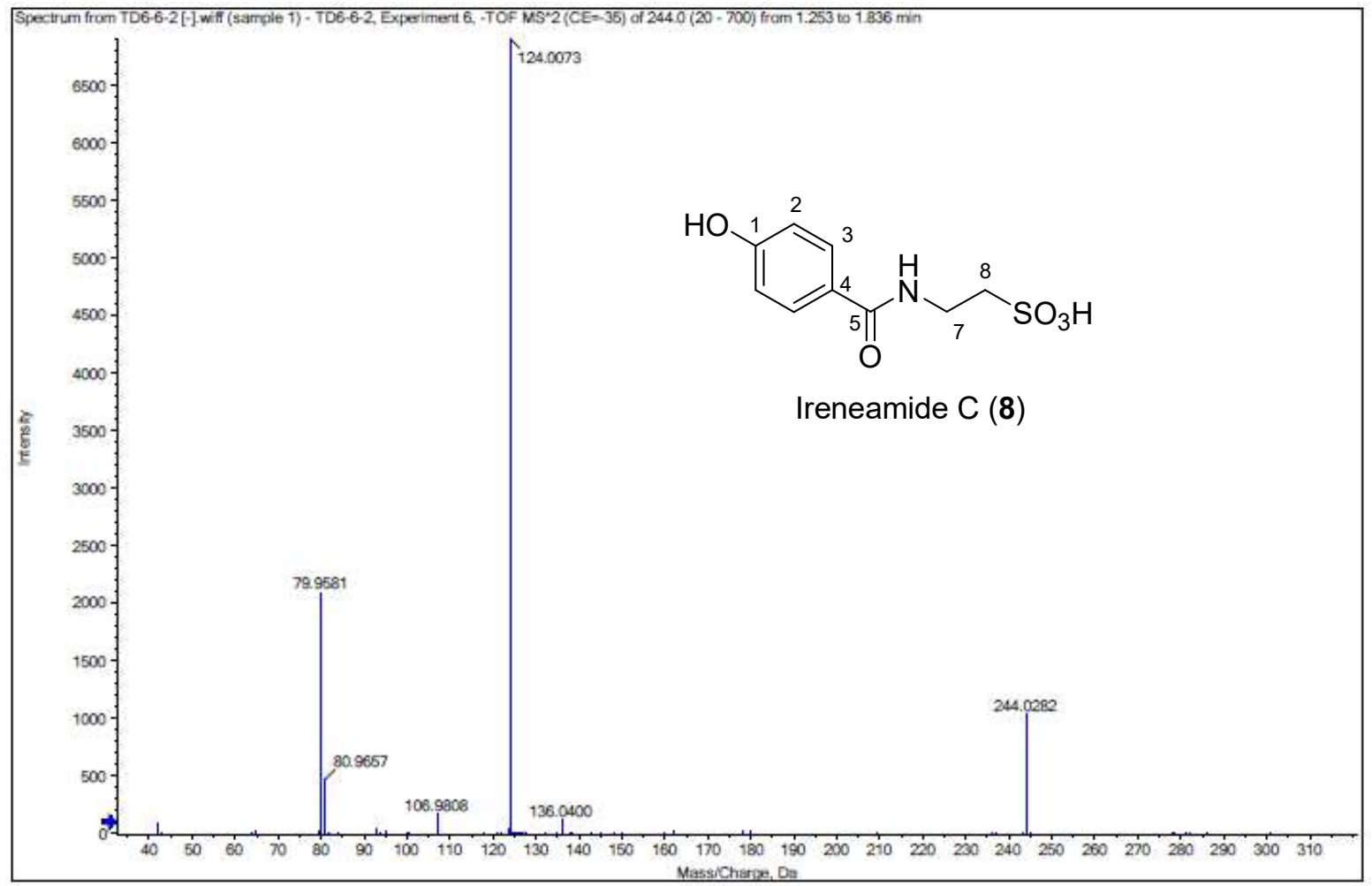

Figure S47. HRESI MS/MS spectrum of ireneamide C (8). Collision Energy (CE) -35V. 


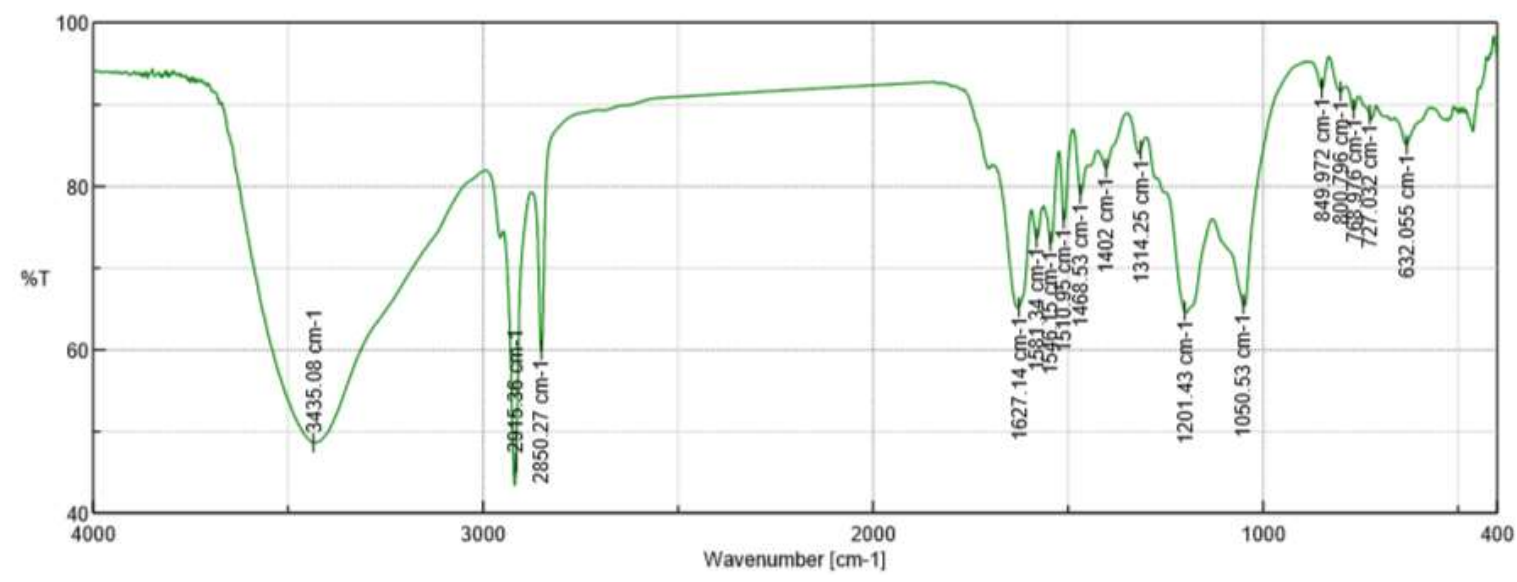

Figure S48. IR spectrum of ireneamide C (8).

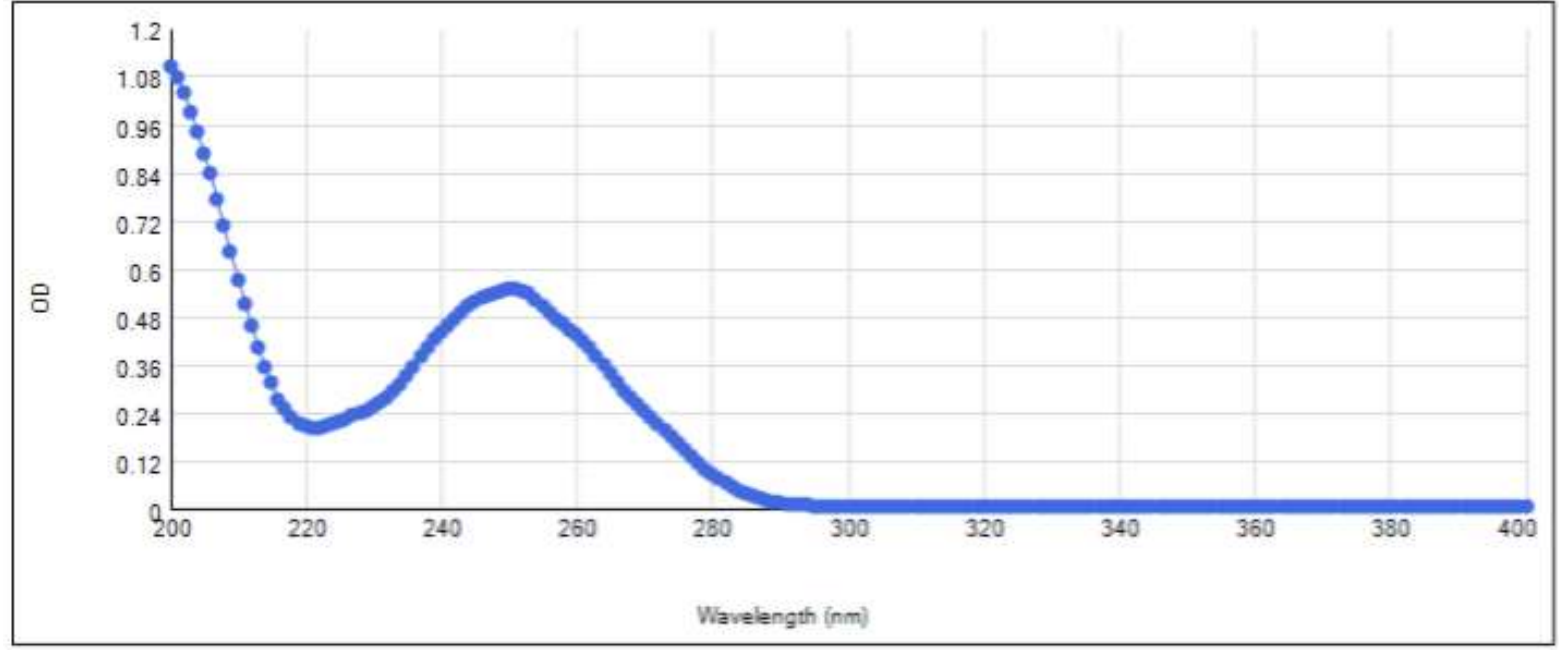

Figure S49. UV spectrum of ireneamide C (8). 
Table S6. NMR data $\left({ }^{1} \mathrm{H}: 400 \mathrm{MHz},{ }^{13} \mathrm{C}: 100 \mathrm{MHz}\right)$ of ireneamide $\mathrm{C}(\mathbf{8})$.

\begin{tabular}{cccccc}
$\# \mathrm{C}$ & $\delta_{\mathrm{C}}$ & $\delta_{\mathrm{H}}$ mult. $(J$ in Hz) & $\mathrm{COSY}$ & HMBC & NOESY \\
\hline 1 & $160.8, \mathrm{C}$ & & & & \\
2 & $117.0, \mathrm{CH}$ & $6.78, \mathrm{dt}^{a}(8.7)$ & 3 & $1,2,4$ & 3 \\
3 & $130.9, \mathrm{CH}$ & $7.52, \mathrm{dt}^{a}(8.7)$ & 2 & $1,3,5$ & 2 \\
4 & $126.9, \mathrm{C}$ & & & & \\
5 & $171.6 . \mathrm{C}$ & & & & \\
7 & $37.2, \mathrm{CH}_{2}$ & $3.57, \mathrm{t}(6.9)$ & 8 & 5,8 & 8 \\
8 & $51.3, \mathrm{CH}_{2}$ & $3.00, \mathrm{t}(6.7)$ & 7 & 7 & 7 \\
\hline
\end{tabular}

Measured at $303 \mathrm{~K}$ in $\mathrm{D}_{2} \mathrm{O}$ with $10 \mu \mathrm{L}$ DMSO- $d_{6}$ as internal standard $\left(\delta_{\mathrm{H}} 2.49\right.$, $\left.\delta_{\mathrm{C}} 39.5 \mathrm{ppm}\right) .{ }^{a}$ Due to second order effect.

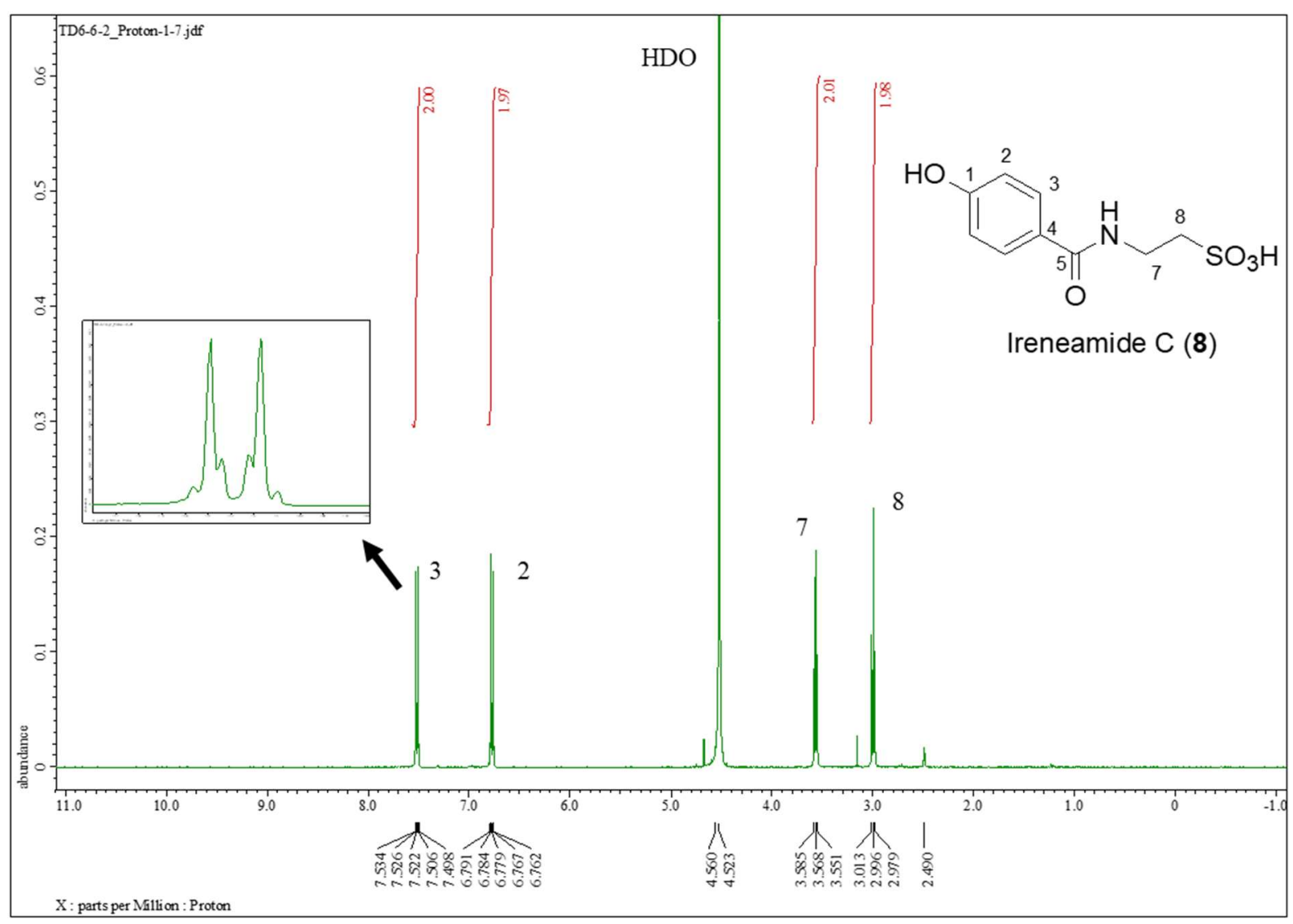

Figure S50. ${ }^{1} \mathrm{H}$ NMR spectrum of ireneamide $\mathrm{C}(\mathbf{8})$ in $\mathrm{D}_{2} \mathrm{O}$ with $10 \mu \mathrm{L} \mathrm{DMSO}-d_{6}(400 \mathrm{MHz})$. Inset is a double triplet like peak. 


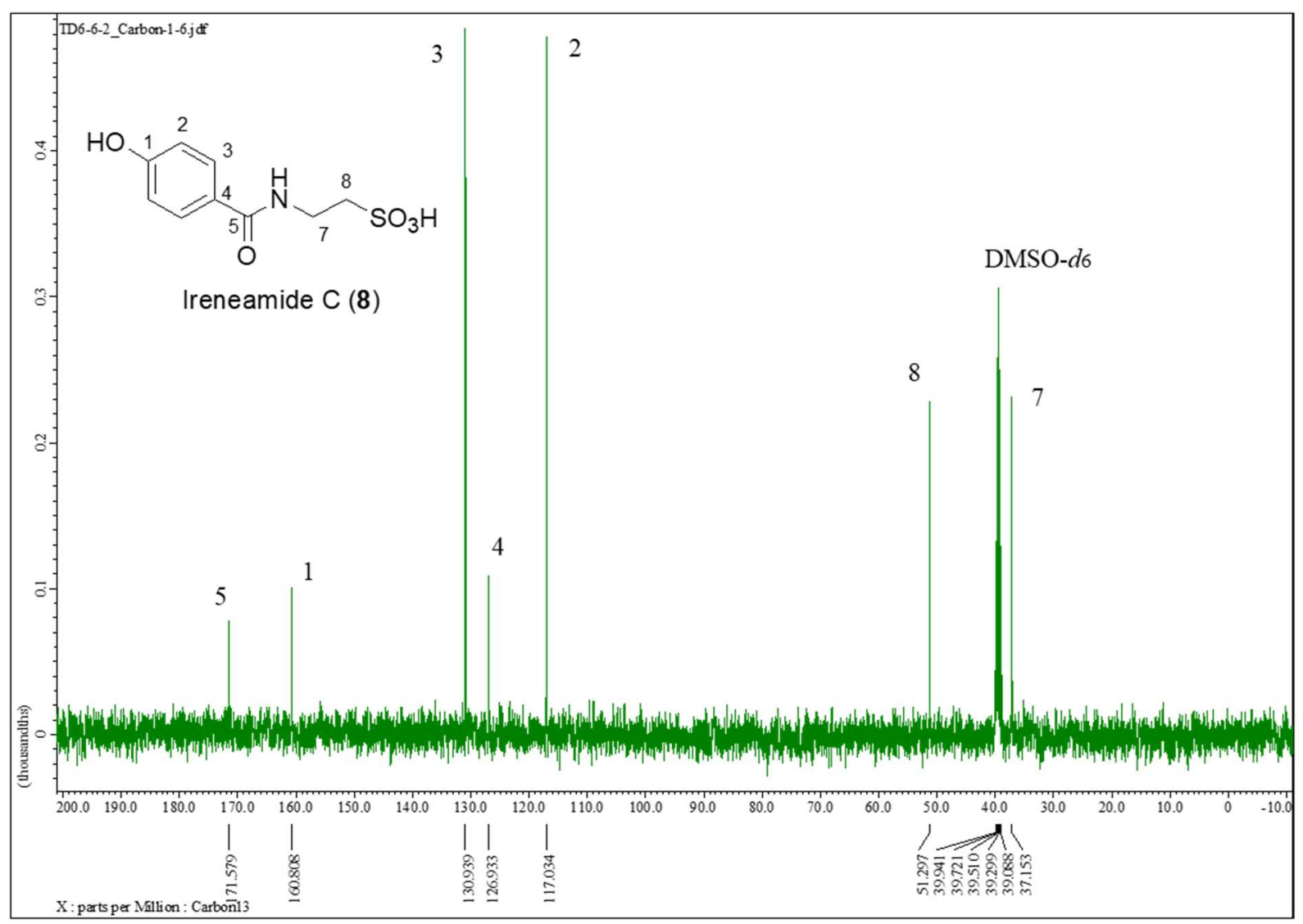

Figure S51. ${ }^{13} \mathrm{C}$ NMR spectrum of ireneamide C (8) in $\mathrm{D}_{2} \mathrm{O}$ with $10 \mu \mathrm{L}$ DMSO- $d_{6}(100 \mathrm{MHz})$.

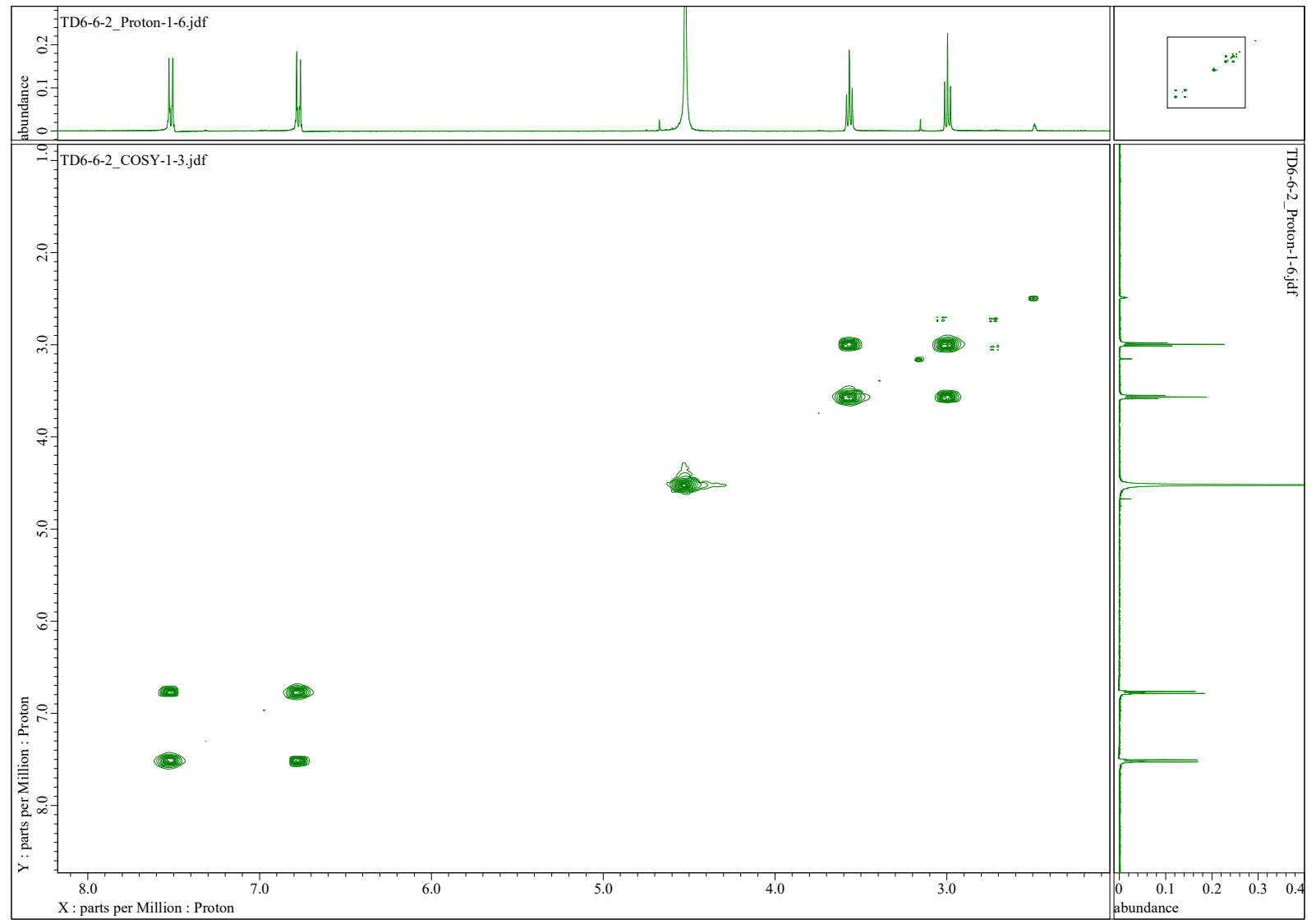

Figure S52. COSY spectrum of ireneamide C (8) in $\mathrm{D}_{2} \mathrm{O}$ with $10 \mu \mathrm{L}$ DMSO- $d_{6}$ 


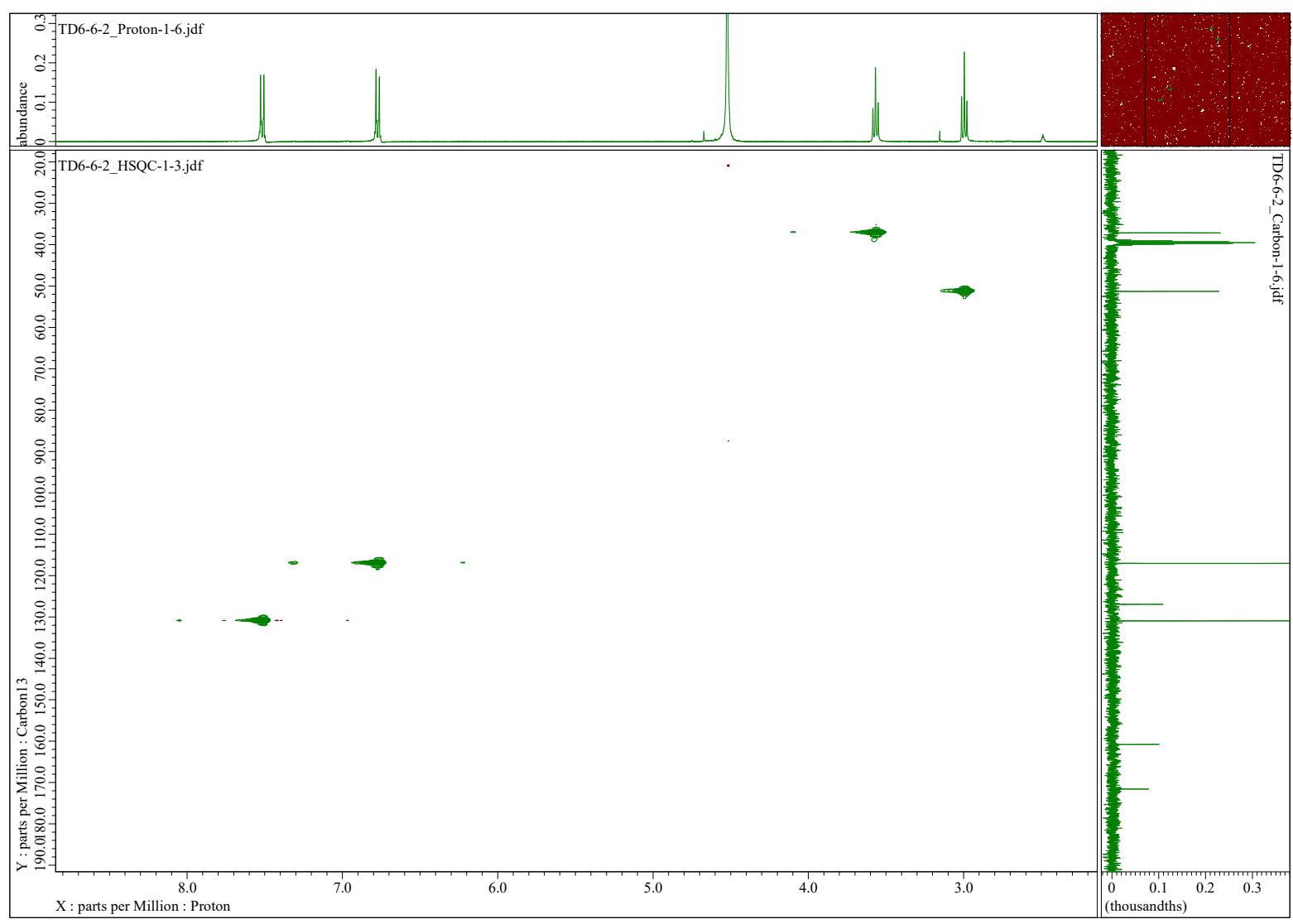

Figure S53. HSQC spectrum of ireneamide C (8) in $\mathrm{D}_{2} \mathrm{O}$ with $10 \mu \mathrm{L}$ DMSO- $d_{6}$.

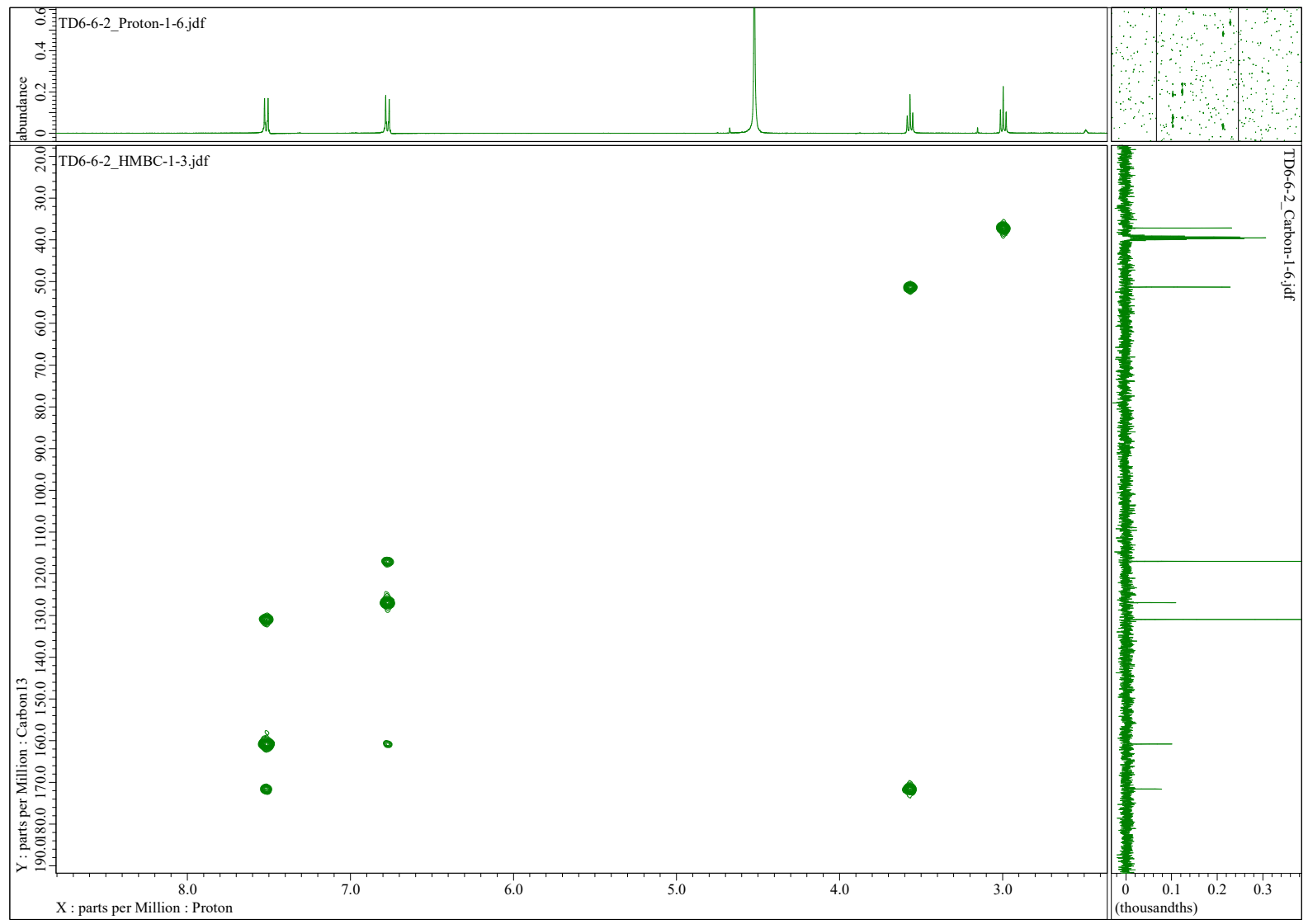

Figure S54. HMBC spectrum of ireneamide C (8) in $\mathrm{D}_{2} \mathrm{O}$ with $10 \mu \mathrm{L}$ DMSO- $d_{6}$. 


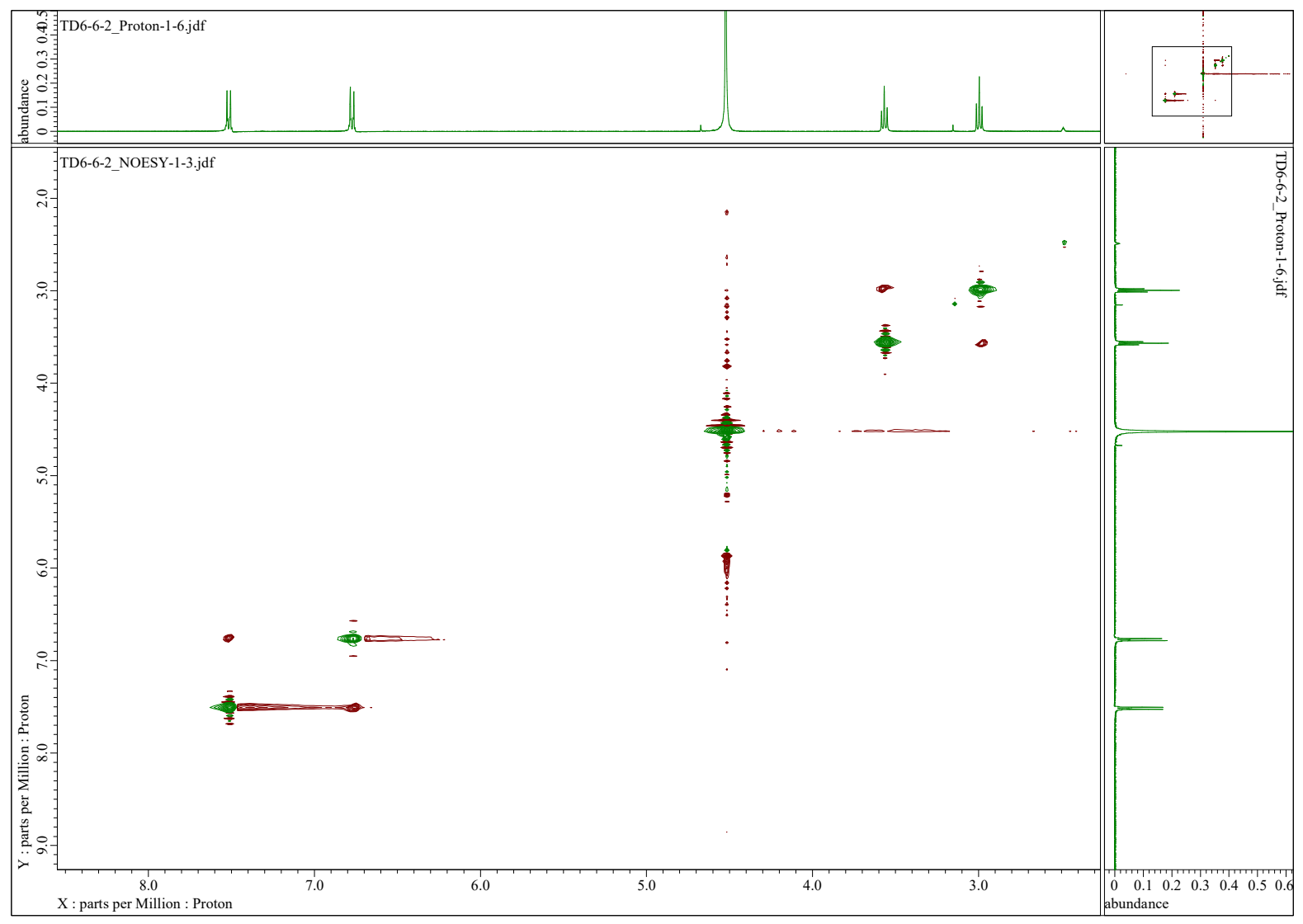

Figure S55. NOESY spectrum of ireneamide $\mathrm{C}(\mathbf{8})$ in $\mathrm{D}_{2} \mathrm{O}$ with $10 \mu \mathrm{L}$ DMSO- $d_{6}$. 


\subsection{Spectral data and NMR assignments for $\mathbf{9}$.}

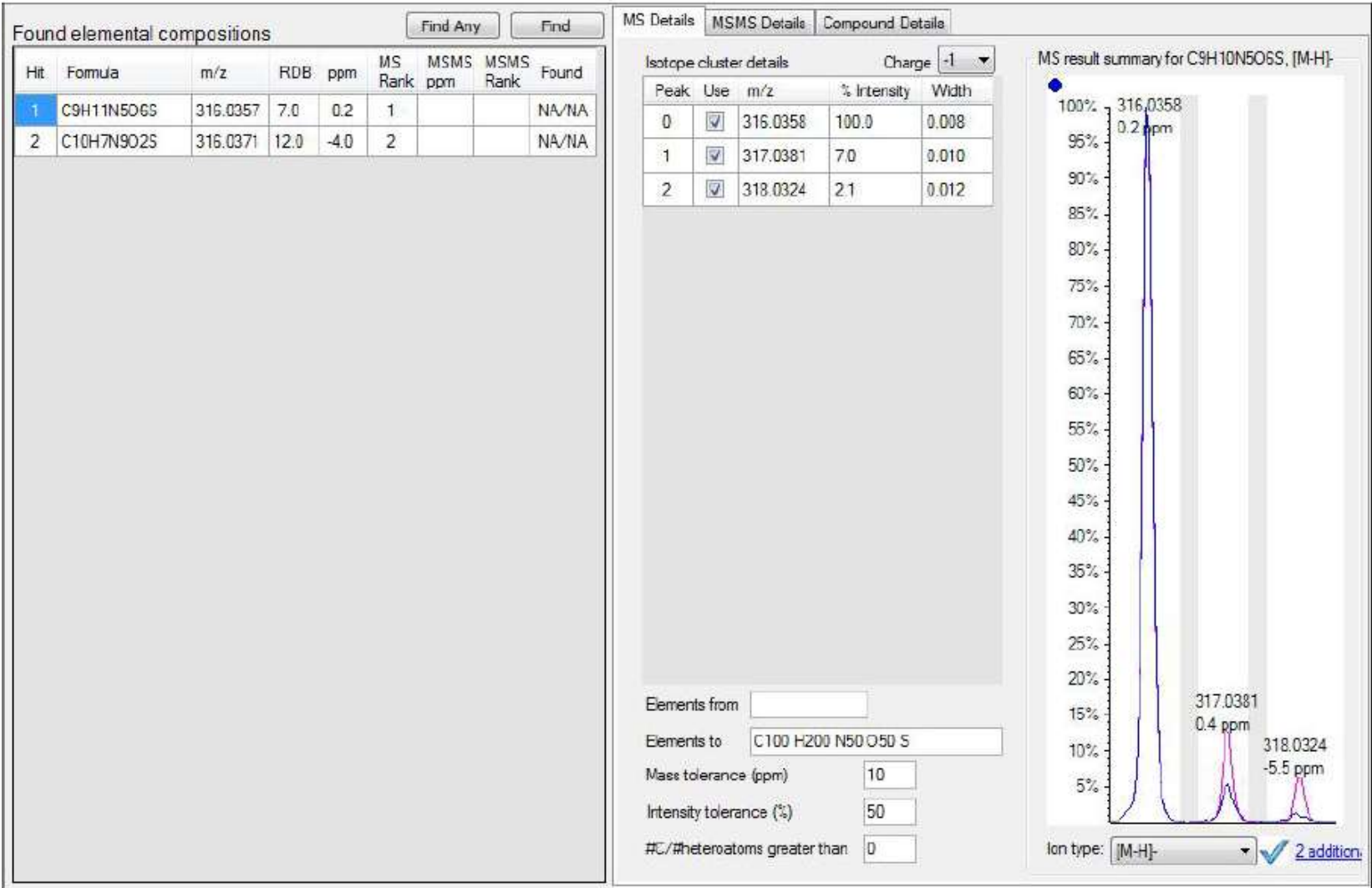

Figure S56. HRESIMS data for 9.

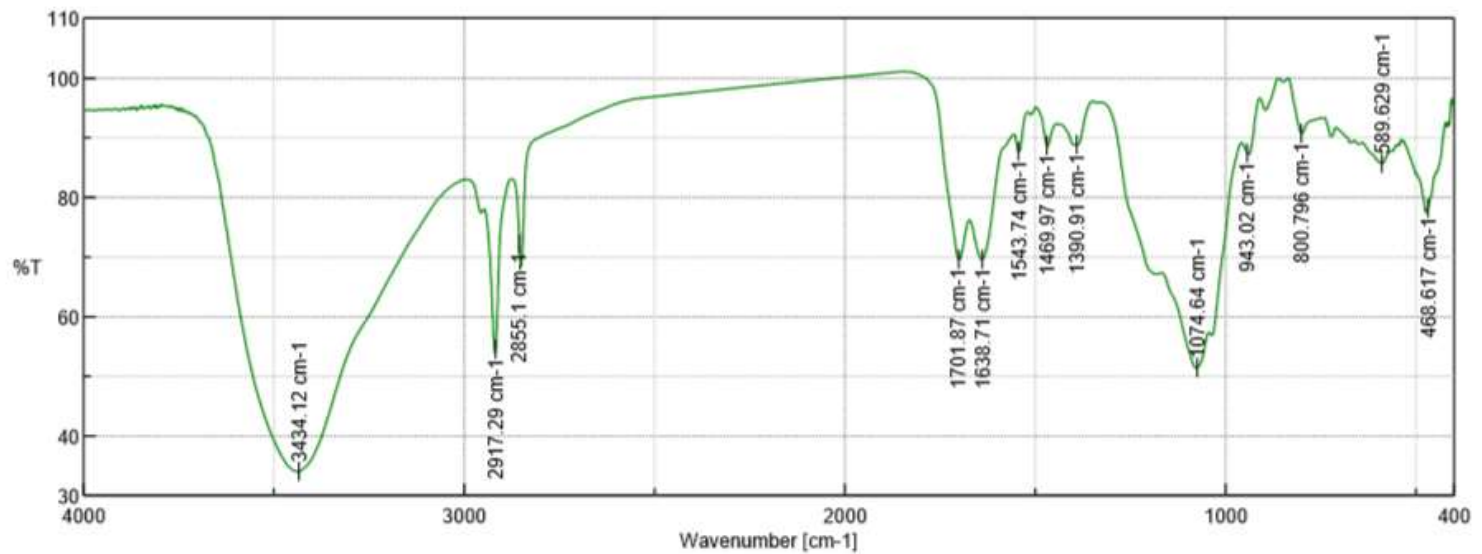

Figure S57. IR spectrum of 9. 


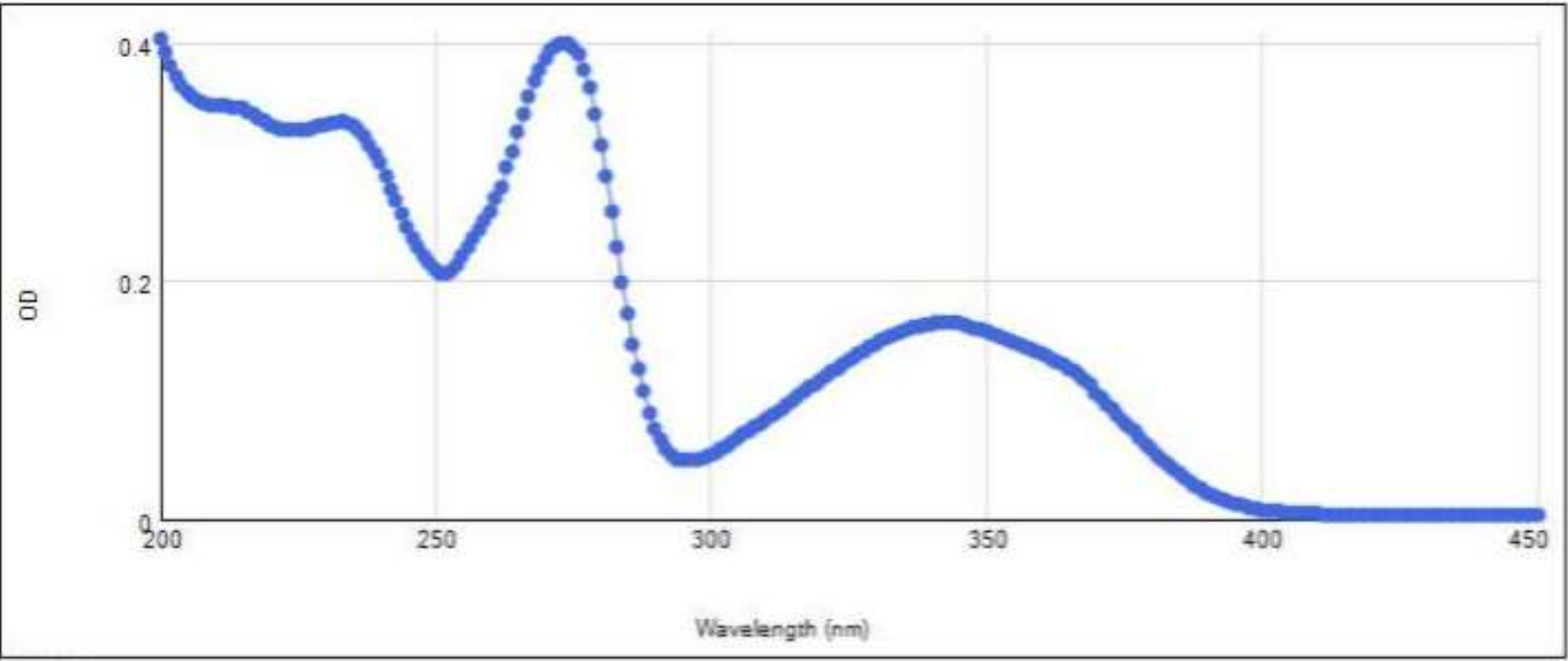

Figure S58. UV spectrum of 9.

9

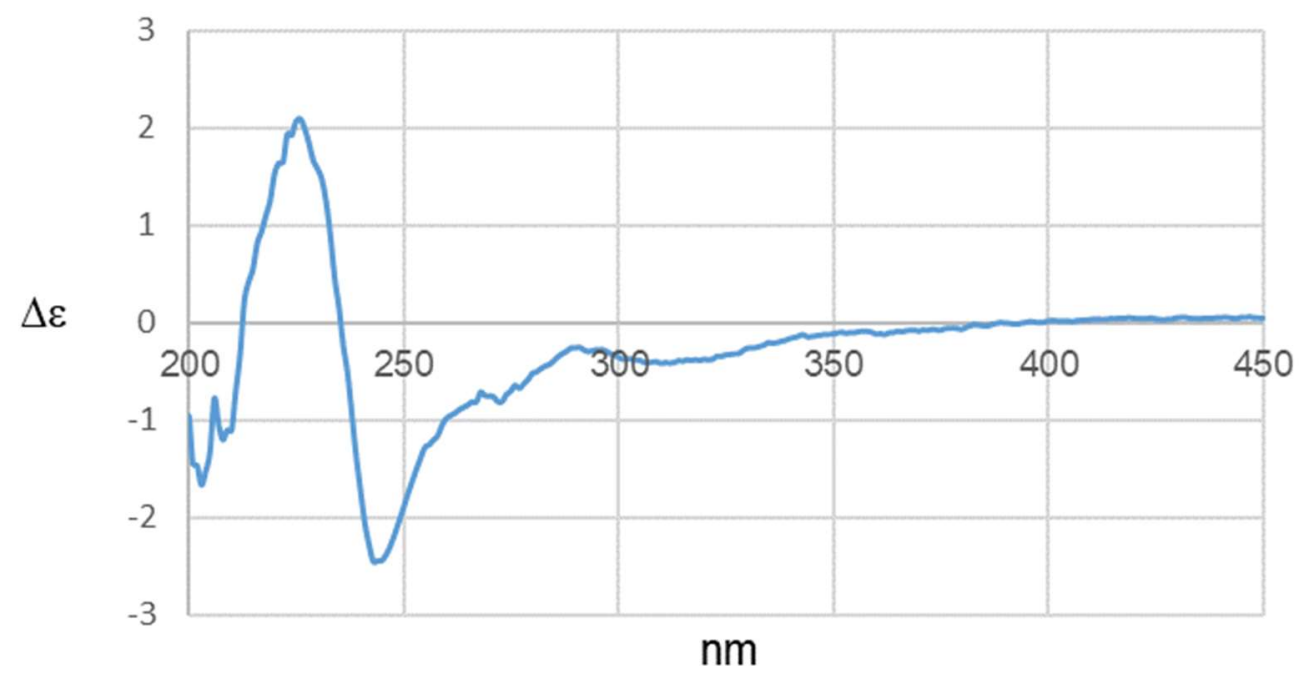

Figure S59. ECD spectrum of 9. 
Table S7. NMR data $\left({ }^{1} \mathrm{H}: 400 \mathrm{MHz},{ }^{13} \mathrm{C} 100 \mathrm{MHz}\right)$ for 9.

\begin{tabular}{cccccc}
$\# \mathrm{C}$ & $\delta \mathrm{C}$ & $\delta_{\mathrm{H}}$ mult. $(J$ in $\mathrm{Hz})$ & $\mathrm{COSY}$ & HMBC & NOESY \\
\hline 2 & $153.4, \mathrm{C}$ & & & & \\
4 & $162.2, \mathrm{C}$ & & & & \\
$4 \mathrm{a}$ & $127.9, \mathrm{C}$ & & & \\
6 & $154.1, \mathrm{C}$ & & $6,8 \mathrm{a}$ & $1^{\prime}(\mathrm{vw}), 2^{\prime}(\mathrm{vw}), 3^{\prime}(\mathrm{vw})$ \\
7 & $150.4, \mathrm{CH}$ & $8.90, \mathrm{~s}$ & & & \\
$8 \mathrm{a}$ & $149.8, \mathrm{C}$ & & & & \\
$1^{\prime}$ & $75.3, \mathrm{CH}$ & $5.03, \mathrm{~d}(5.5)$ & $2^{\prime}$ & $6,7,2^{\prime}, 3^{\prime}$ & $7,2^{\prime}, 3^{\prime}$ \\
$2^{\prime}$ & $79.4, \mathrm{CH}$ & 4.73, quin $(6.2)$ & $1^{\prime}, 3^{\prime}$ & $6,1^{\prime}, 3^{\prime}$ & $7(\mathrm{vw}), 1^{\prime}, 3^{\prime}$ \\
$3^{\prime}$ & $16.7, \mathrm{CH} 3$ & $1.37, \mathrm{~d}(6.4)$ & $2^{\prime}$ & $1^{\prime}, 2^{\prime}$ & $7(\mathrm{vw}), 1^{\prime}, 2^{\prime}$ \\
\hline
\end{tabular}

Measured at $323 \mathrm{~K}$ in $\mathrm{D}_{2} \mathrm{O}$ with $5 \mu \mathrm{L} \mathrm{CD}_{3} \mathrm{OD}$ as internal standard $\left(\delta_{\mathrm{H}} 3.30, \delta_{\mathrm{C}} 49.15 \mathrm{ppm}\right)$.

$\mathrm{vw}=$ very weak signal

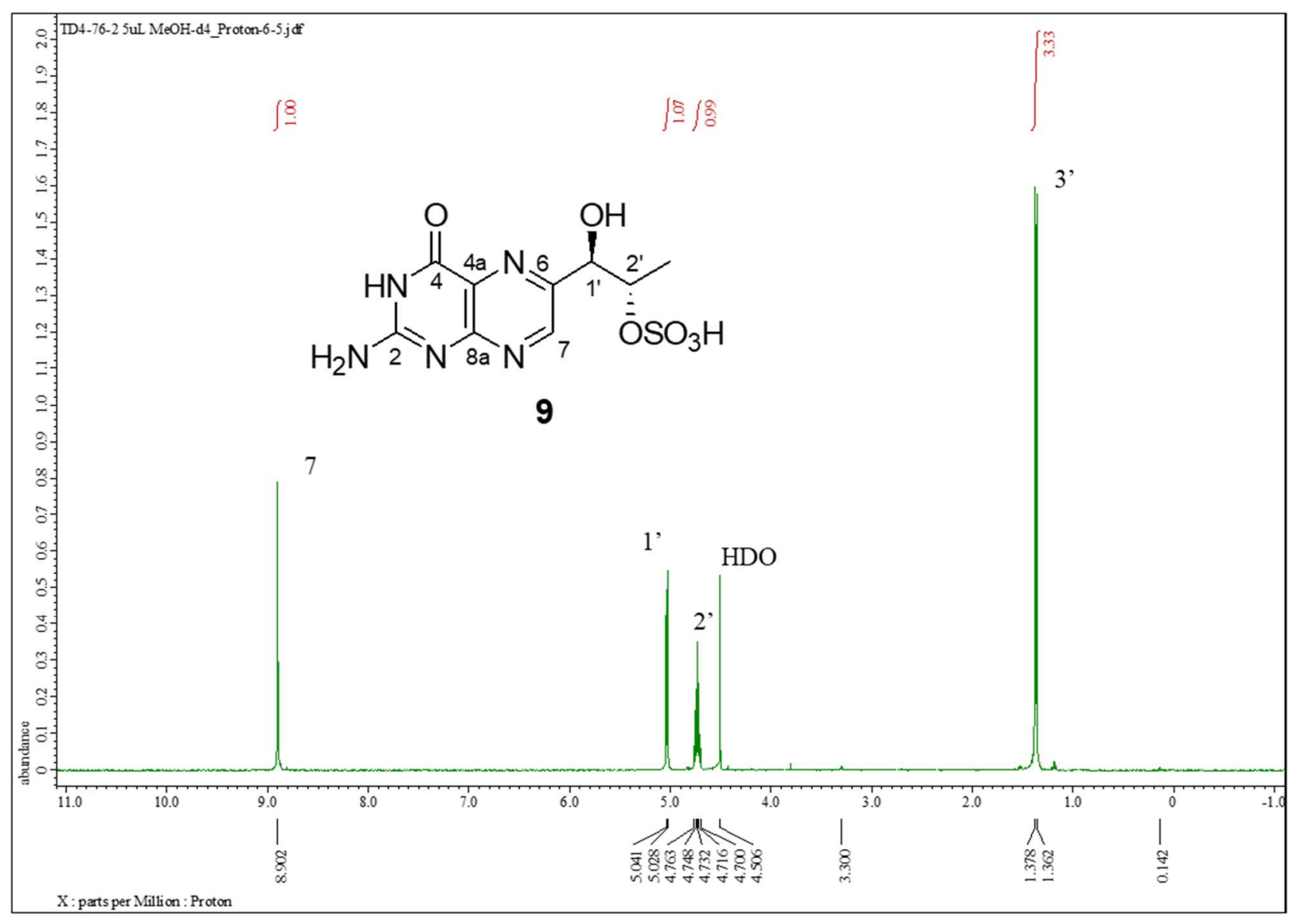

Figure S60. ${ }^{1} \mathrm{H}$ NMR spectrum of 9 in $\mathrm{D}_{2} \mathrm{O}$ with $5 \mu \mathrm{LCD}_{3} \mathrm{OD}$ at $323 \mathrm{~K}(400 \mathrm{MHz})$. 


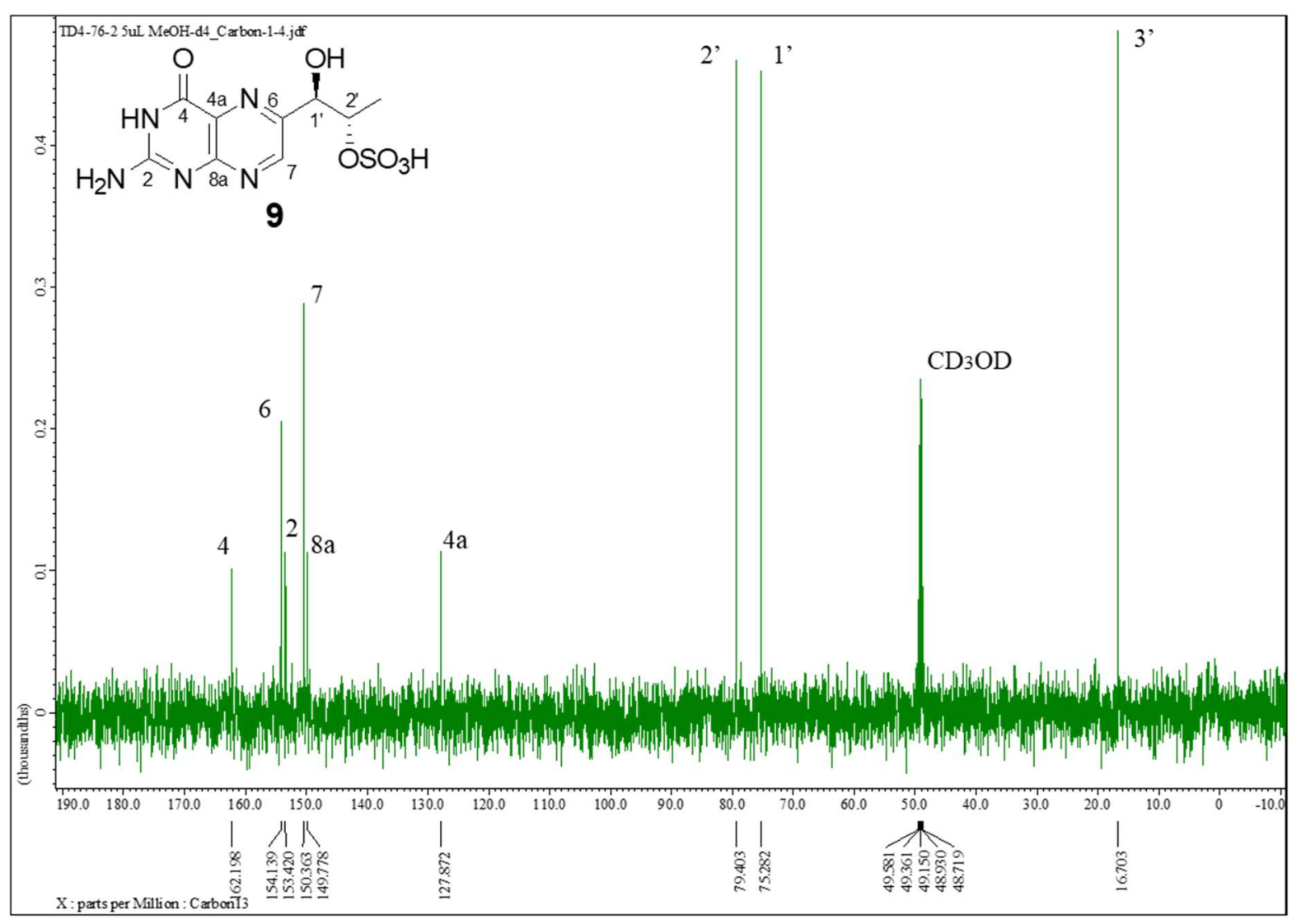

Figure S61. ${ }^{13} \mathrm{C}$ NMR spectrum of 9 in $\mathrm{D}_{2} \mathrm{O}$ with $5 \mu \mathrm{L} \mathrm{CD}{ }_{3} \mathrm{OD}$ at $323 \mathrm{~K}(100 \mathrm{MHz})$.

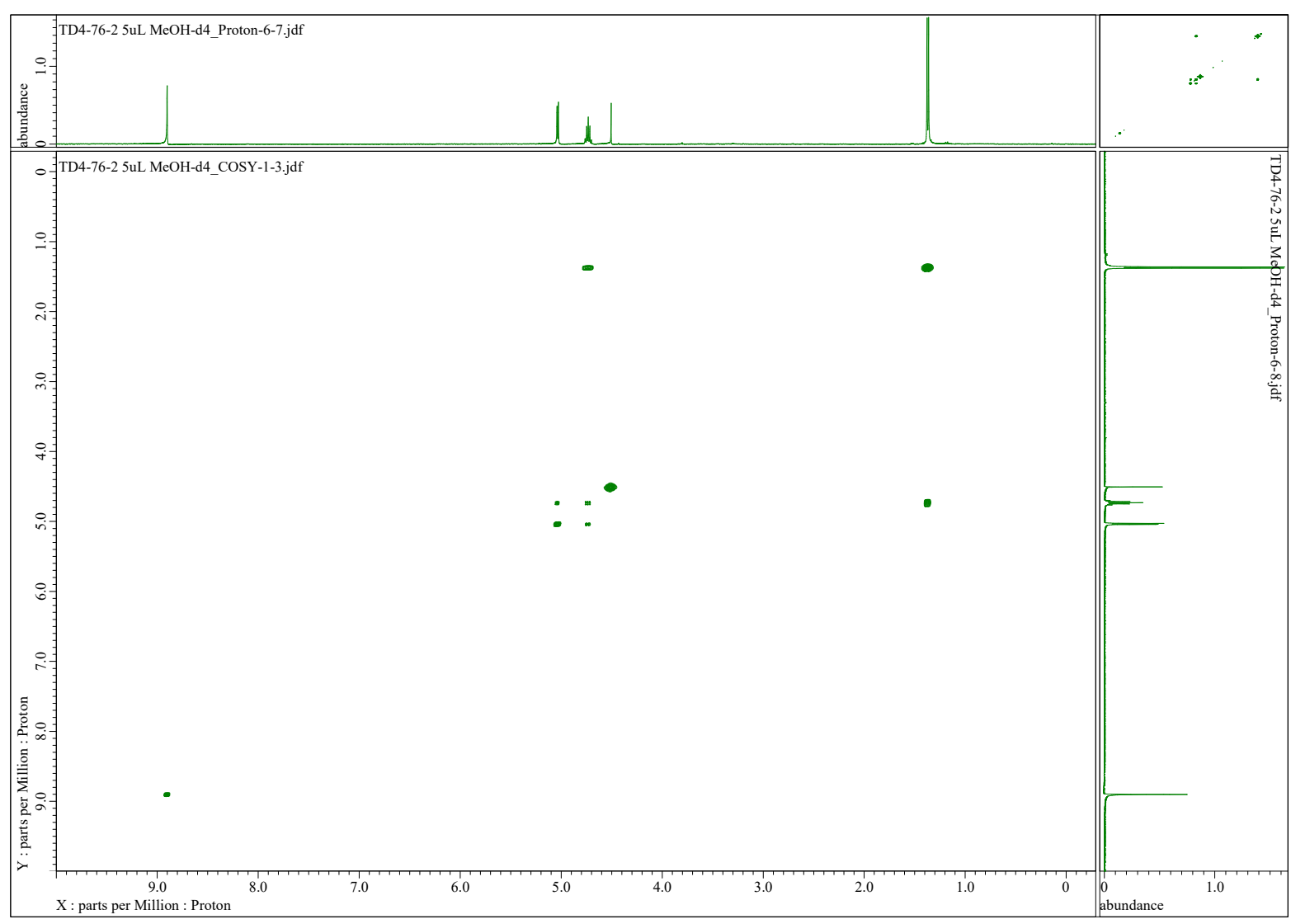

Figure S62. COSY spectrum of 9 in $\mathrm{D}_{2} \mathrm{O}$ with $5 \mu \mathrm{L} \mathrm{CD}{ }_{3} \mathrm{OD}$. 


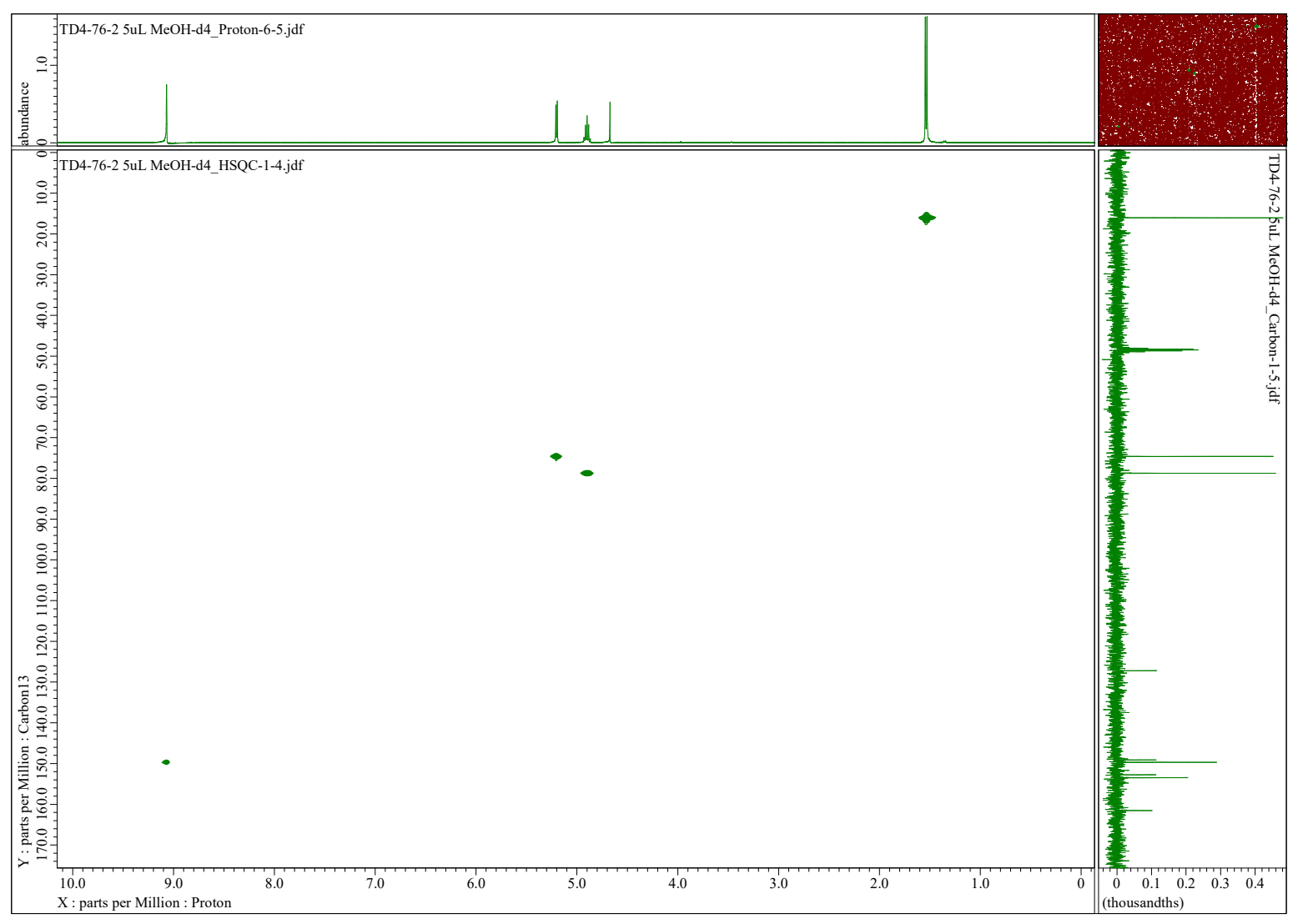

Figure S63. HSQC spectrum of 9 in $\mathrm{D}_{2} \mathrm{O}$ with $5 \mu \mathrm{L} \mathrm{CD}{ }_{3} \mathrm{OD}$.

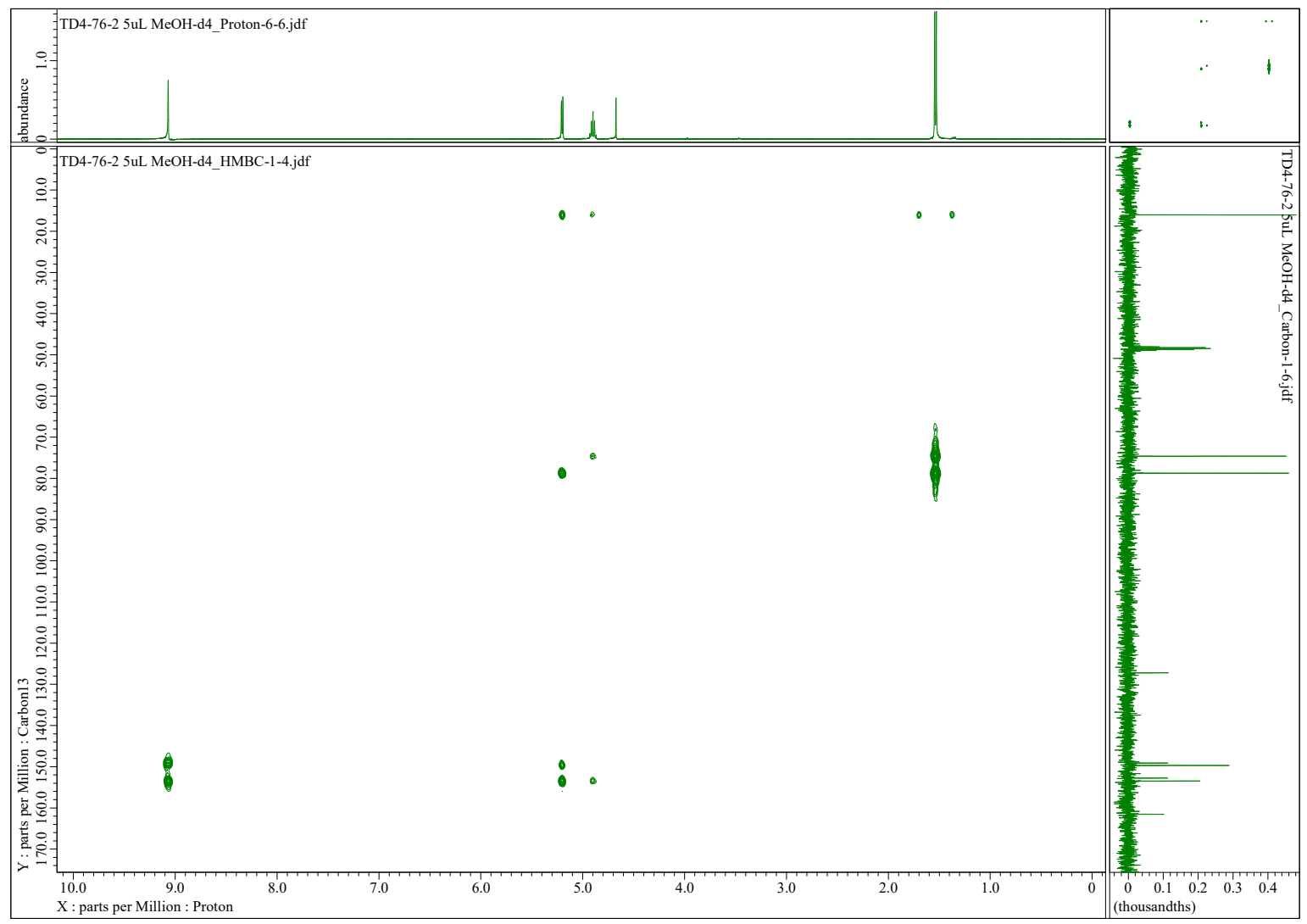

Figure S64. HMBC spectrum of 9 in $\mathrm{D}_{2} \mathrm{O}$ with $5 \mu \mathrm{LCD}_{3} \mathrm{OD}$. 


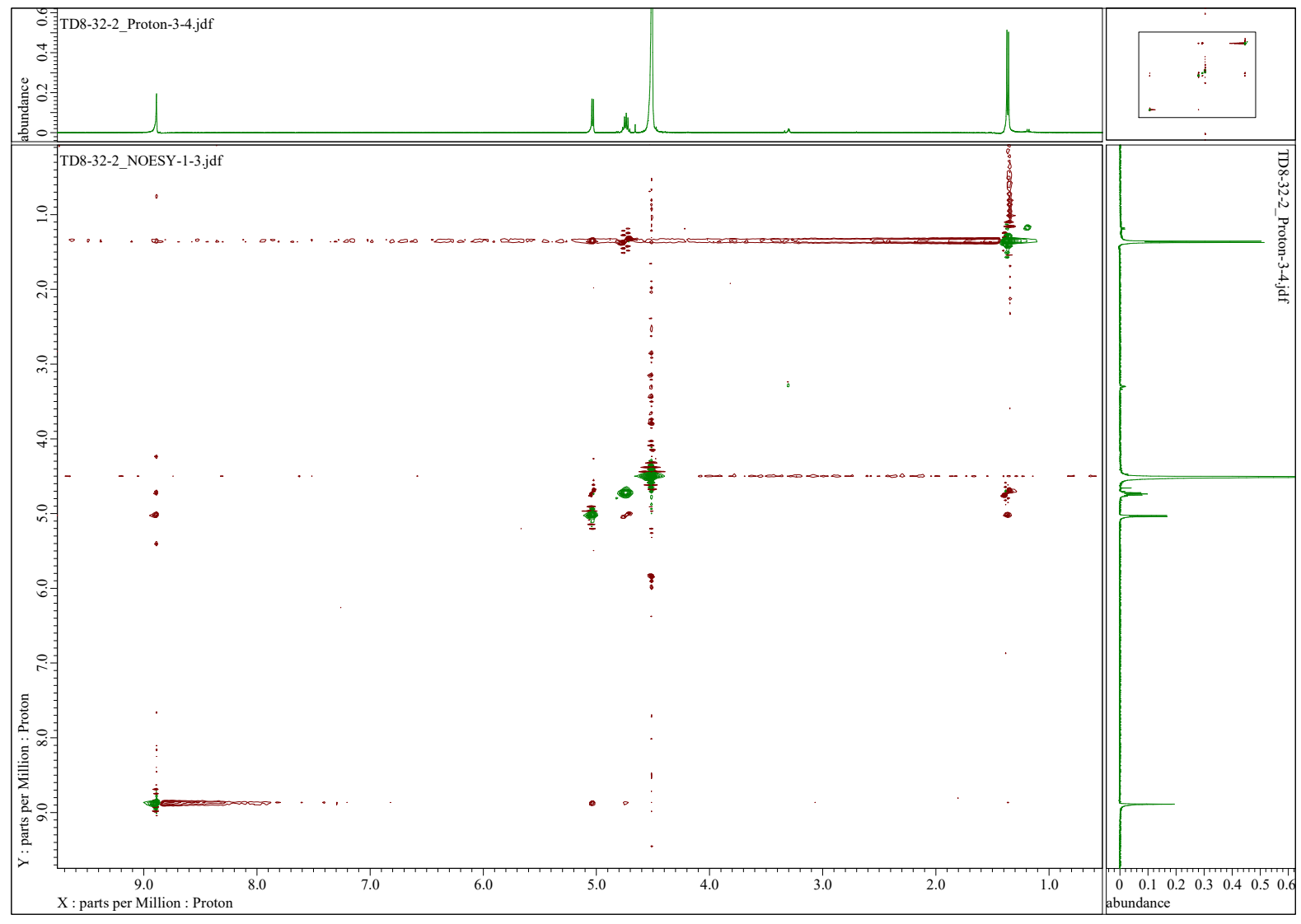

Figure S65. NOESY spectrum of 9 in $\mathrm{D}_{2} \mathrm{O}$ with $5 \mu \mathrm{L} \mathrm{CD}_{3} \mathrm{OD}$. 


\subsection{Spectral data and NMR assignments for $\mathbf{1 0 .}$}

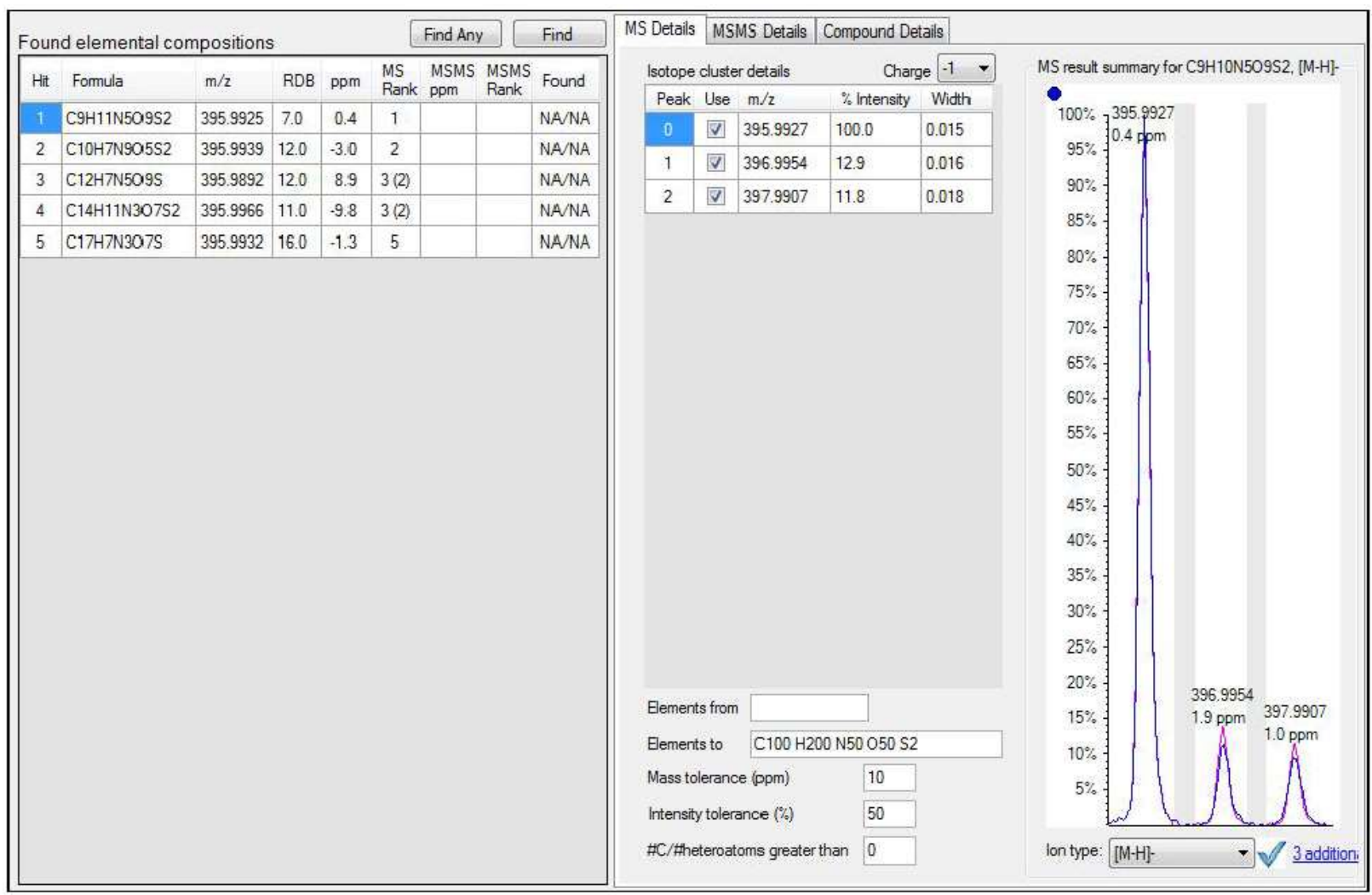

Figure S66. HRESIMS data for 10.

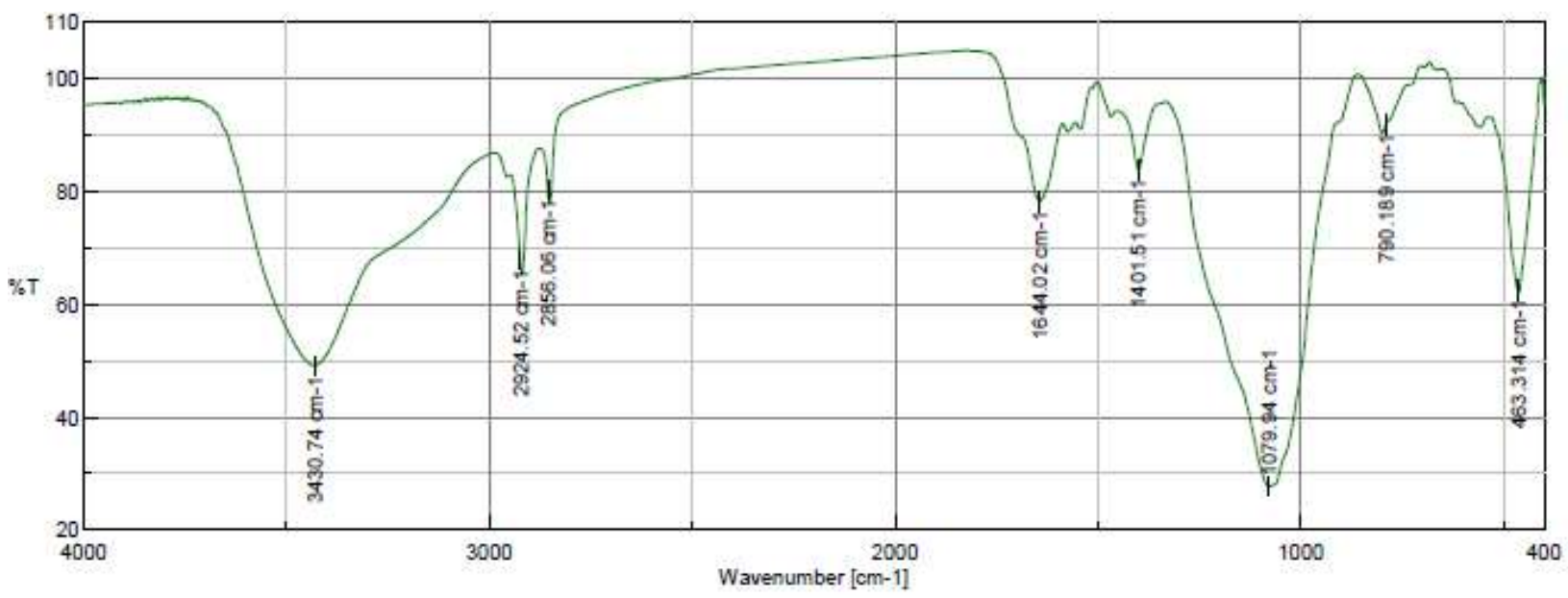

Figure S67. IR spectrum of $\mathbf{1 0 .}$ 


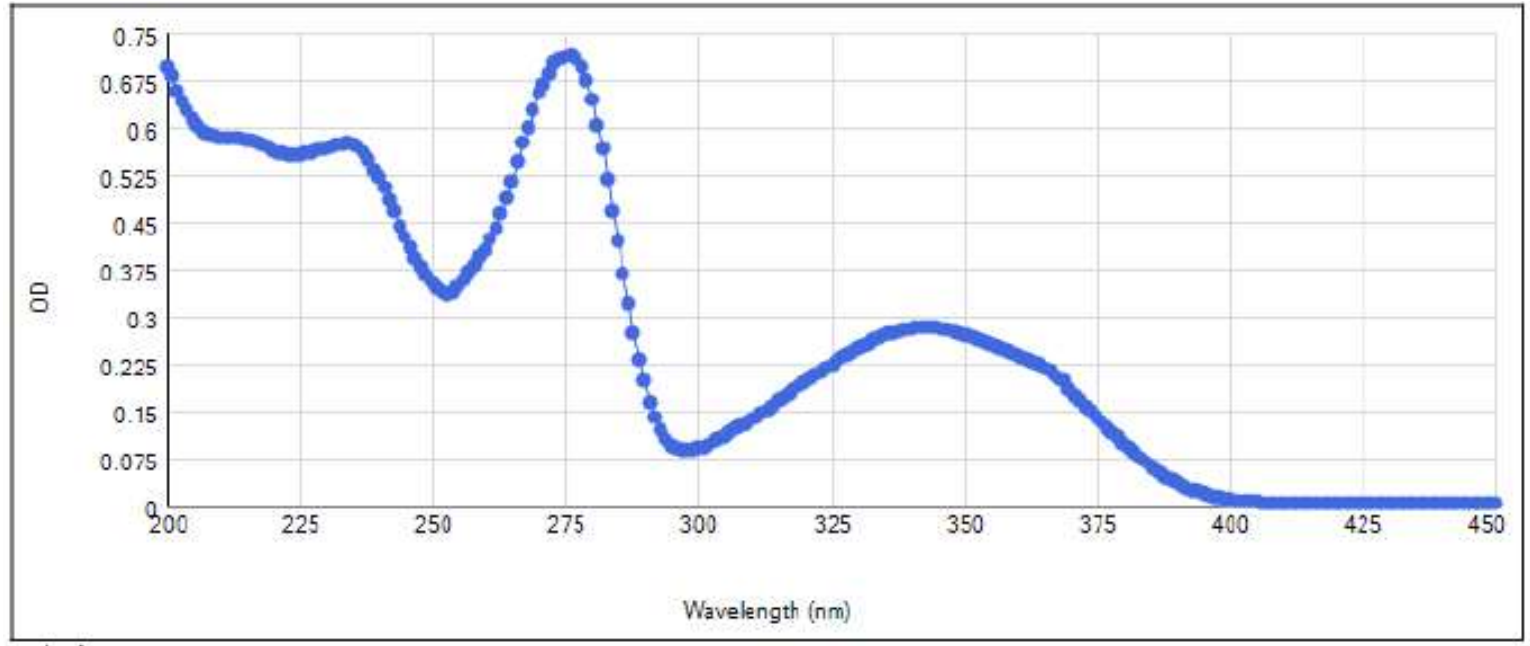

Figure S68. UV spectrum of $\mathbf{1 0 .}$

10

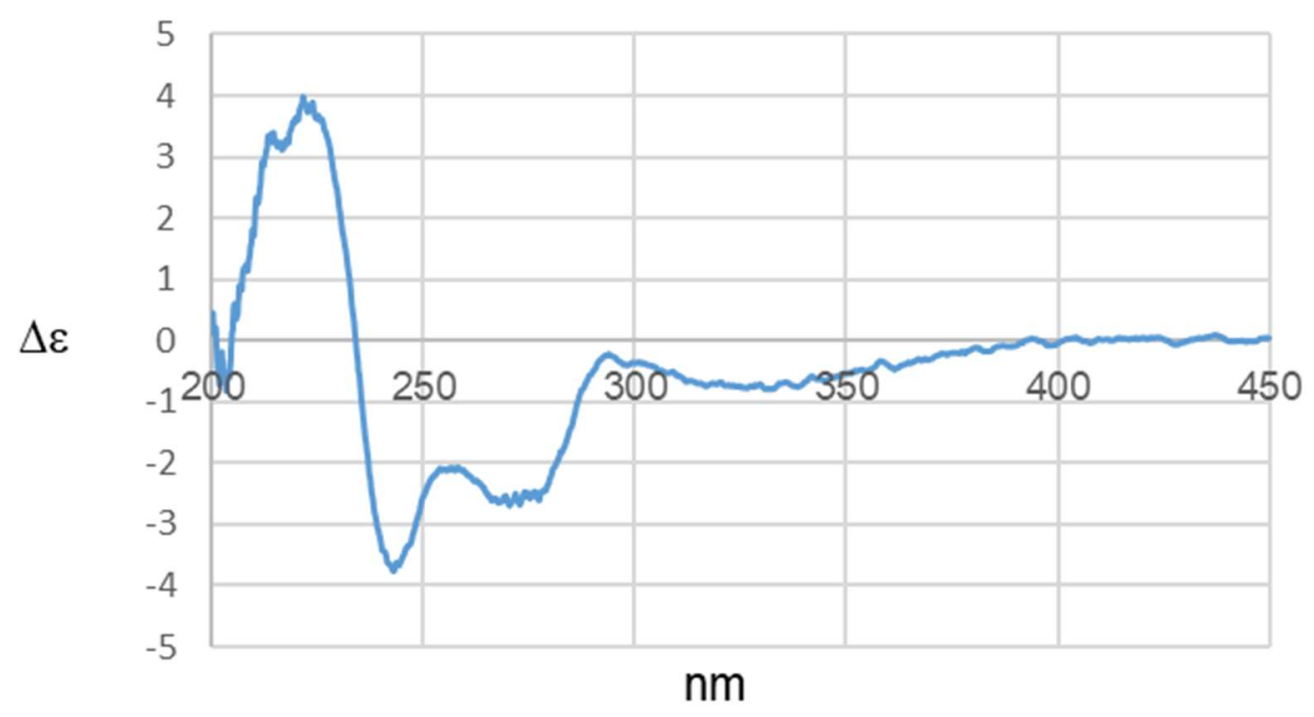

Figure S69. ECD spectrum of $\mathbf{1 0 .}$ 
Table S8. NMR data $\left({ }^{1} \mathrm{H}: 400 \mathrm{MHz},{ }^{13} \mathrm{C} 100 \mathrm{MHz}\right)$ of 10.

\begin{tabular}{|c|c|c|c|c|c|}
\hline \#C & $\delta_{\mathrm{C}}$ & $\delta_{\mathrm{H}}$ mult. $(J$ in $\mathrm{Hz})$ & COSY & HMBC & NOESY \\
\hline 2 & 155.7, C & & & & \\
\hline 4 & $165.4, \mathrm{C}$ & & & & \\
\hline $4 a$ & 128.6, C & & & & \\
\hline 6 & $149.0, \mathrm{C}$ & & & & \\
\hline 7 & $150.6, \mathrm{CH}$ & $8.84, \mathrm{~s}$ & & $6,8 \mathrm{a}$ & \\
\hline $8 \mathrm{a}$ & 155.5, C & & & & \\
\hline $1^{\prime}$ & $81.3, \mathrm{CH}$ & $5.40, \mathrm{~d}(6.0)$ & $2^{\prime}$ & $6,7,2^{\prime}, 3^{\prime}$ & $7,2^{\prime}, 3^{\prime}$ \\
\hline $2^{\prime}$ & $77.8, \mathrm{CH}$ & 4.82 , quin $(6.4)$ & $1^{\prime}, 3^{\prime}$ & $6,1^{\prime}$ & $7,1^{\prime}, 3^{\prime}$ \\
\hline $3^{\prime}$ & $17.3, \mathrm{CH}_{3}$ & $1.45, \mathrm{~d}(6.4)$ & $2^{\prime}$ & $1^{\prime}, 2^{\prime}$ & $1^{\prime}, 2^{\prime}$ \\
\hline \multicolumn{6}{|c|}{ Measured at $323 \mathrm{~K}$ in $\mathrm{D}_{2} \mathrm{O}$ with $10 \mu \mathrm{L} \mathrm{CD}_{3} \mathrm{OD}$ as internal standard $\left(\delta_{\mathrm{H}} 3.30, \delta\right.$} \\
\hline
\end{tabular}

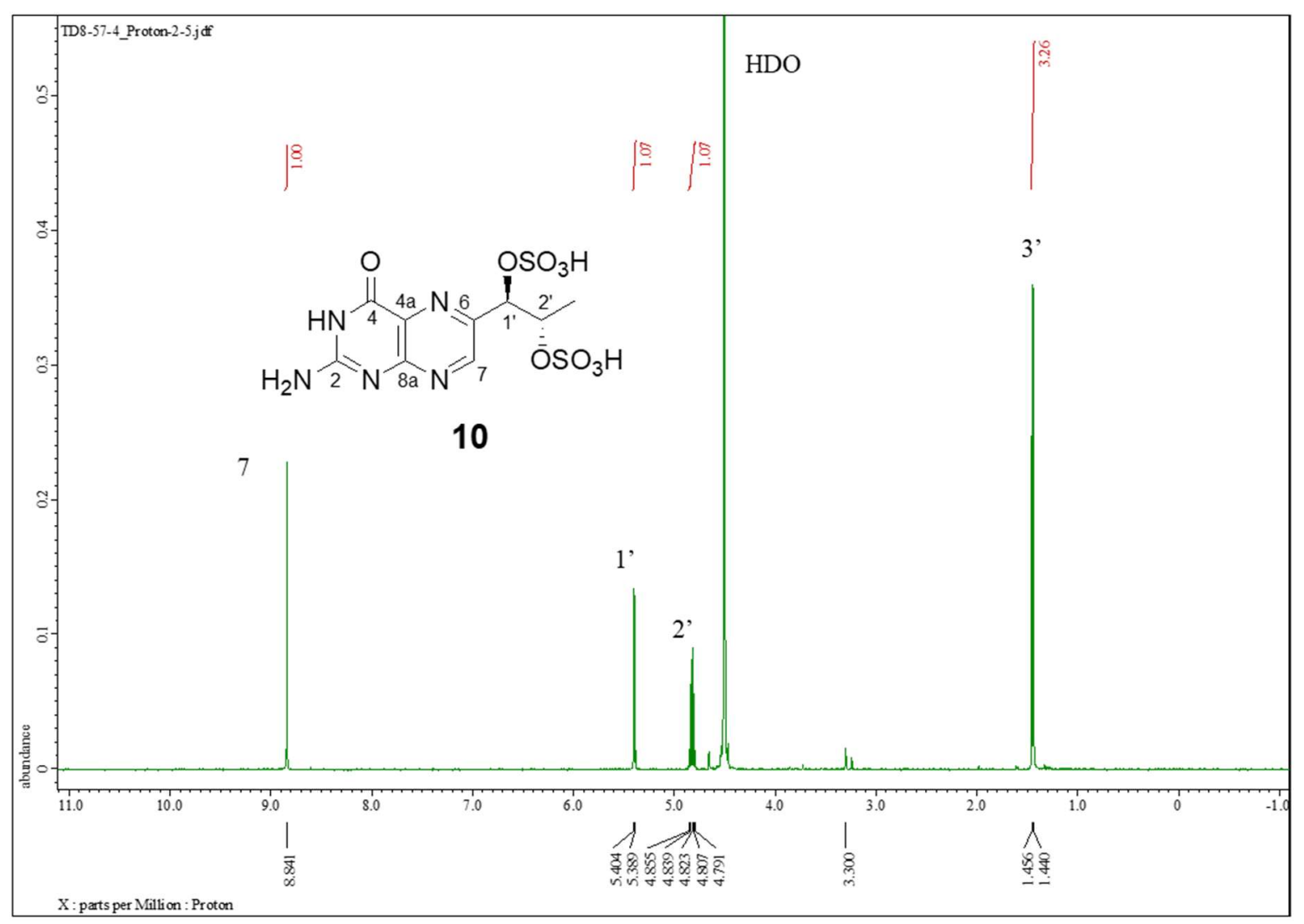

Figure S70. ${ }^{1} \mathrm{H}$ NMR spectrum of $\mathbf{1 0}$ in $\mathrm{D}_{2} \mathrm{O}$ with $10 \mu \mathrm{L} \mathrm{CD}{ }_{3} \mathrm{OD}$ at $323 \mathrm{~K}(400 \mathrm{MHz})$. 


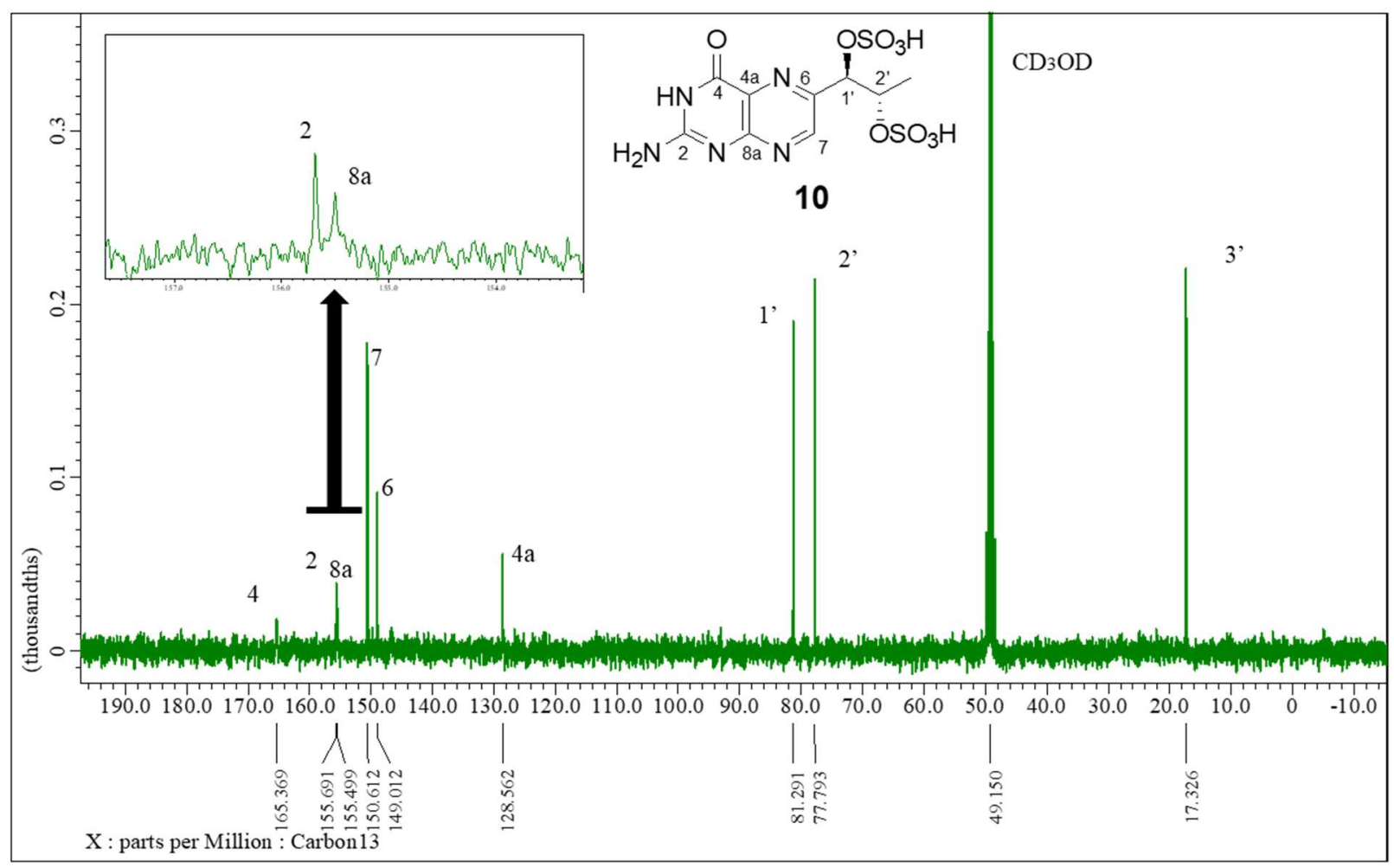

Figure S71. ${ }^{13} \mathrm{C}$ NMR spectrum of 10 in $\mathrm{D}_{2} \mathrm{O}$ with $10 \mu \mathrm{L} \mathrm{CD}{ }_{3} \mathrm{OD}$ at $323 \mathrm{~K}(100 \mathrm{MHz})$.

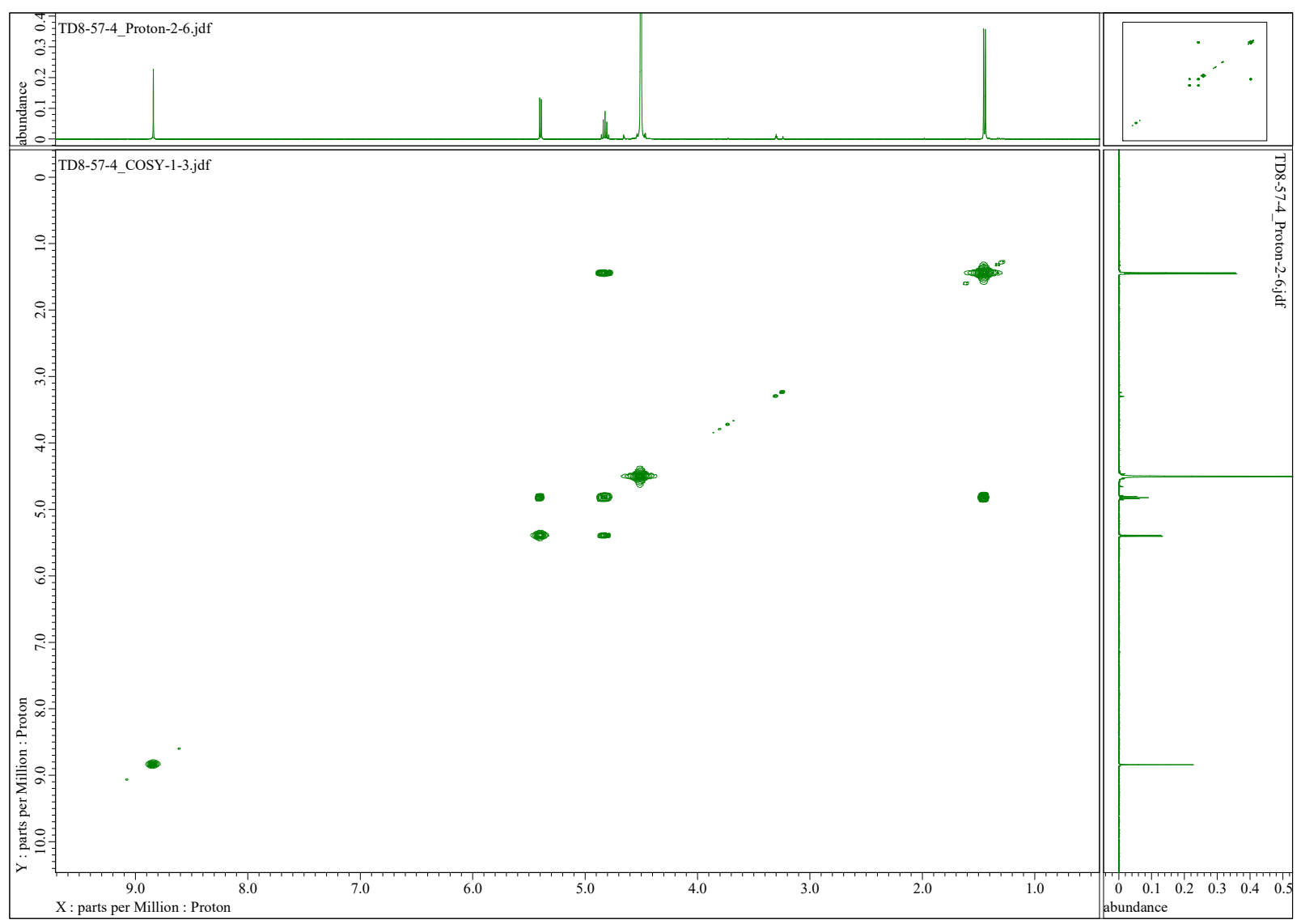

Figure S72. COSY spectrum of 10 in $\mathrm{D}_{2} \mathrm{O}$ with $10 \mu \mathrm{LCD} \mathrm{CD}_{3} \mathrm{OD}$. 


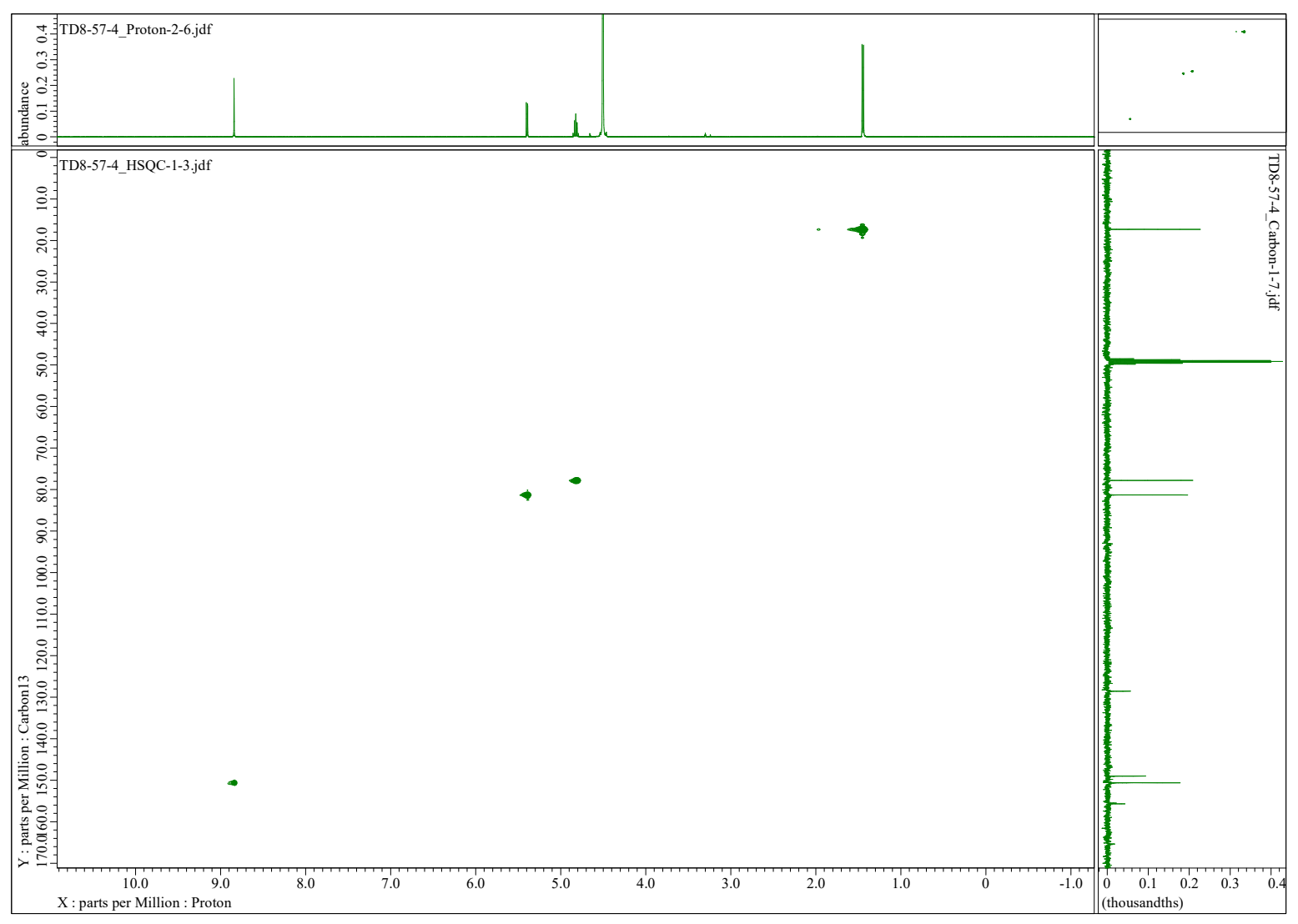

Figure S73. HSQC spectrum of 10 in $\mathrm{D}_{2} \mathrm{O}$ with $10 \mu \mathrm{L} \mathrm{CD}_{3} \mathrm{OD}$.

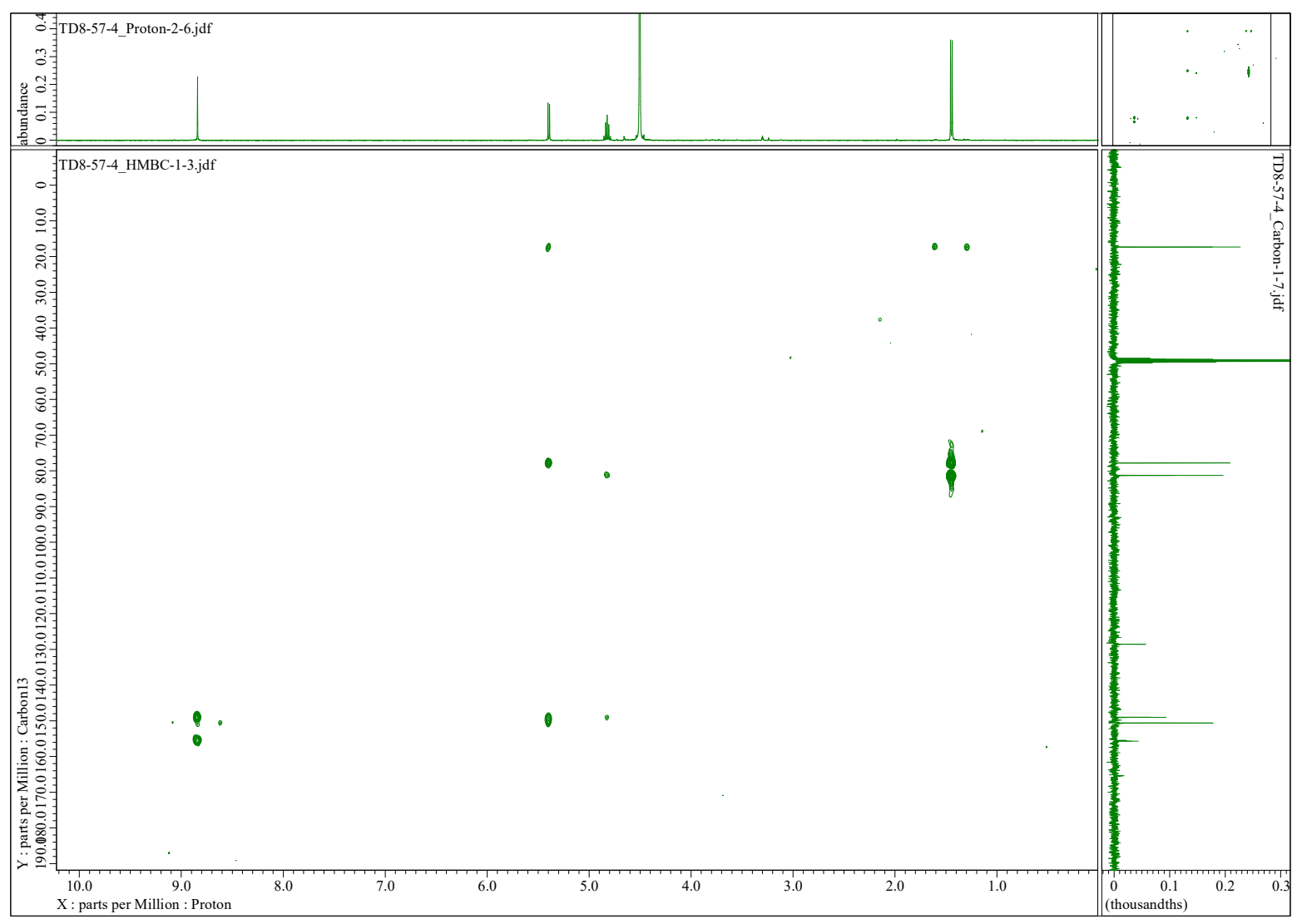

Figure S74. HMBC spectrum of 10 in $\mathrm{D}_{2} \mathrm{O}$ with $10 \mu \mathrm{L} \mathrm{CD}_{3} \mathrm{OD}$. 
3.6. Spectral data and NMR assignments for $\mathbf{1 1 .}$

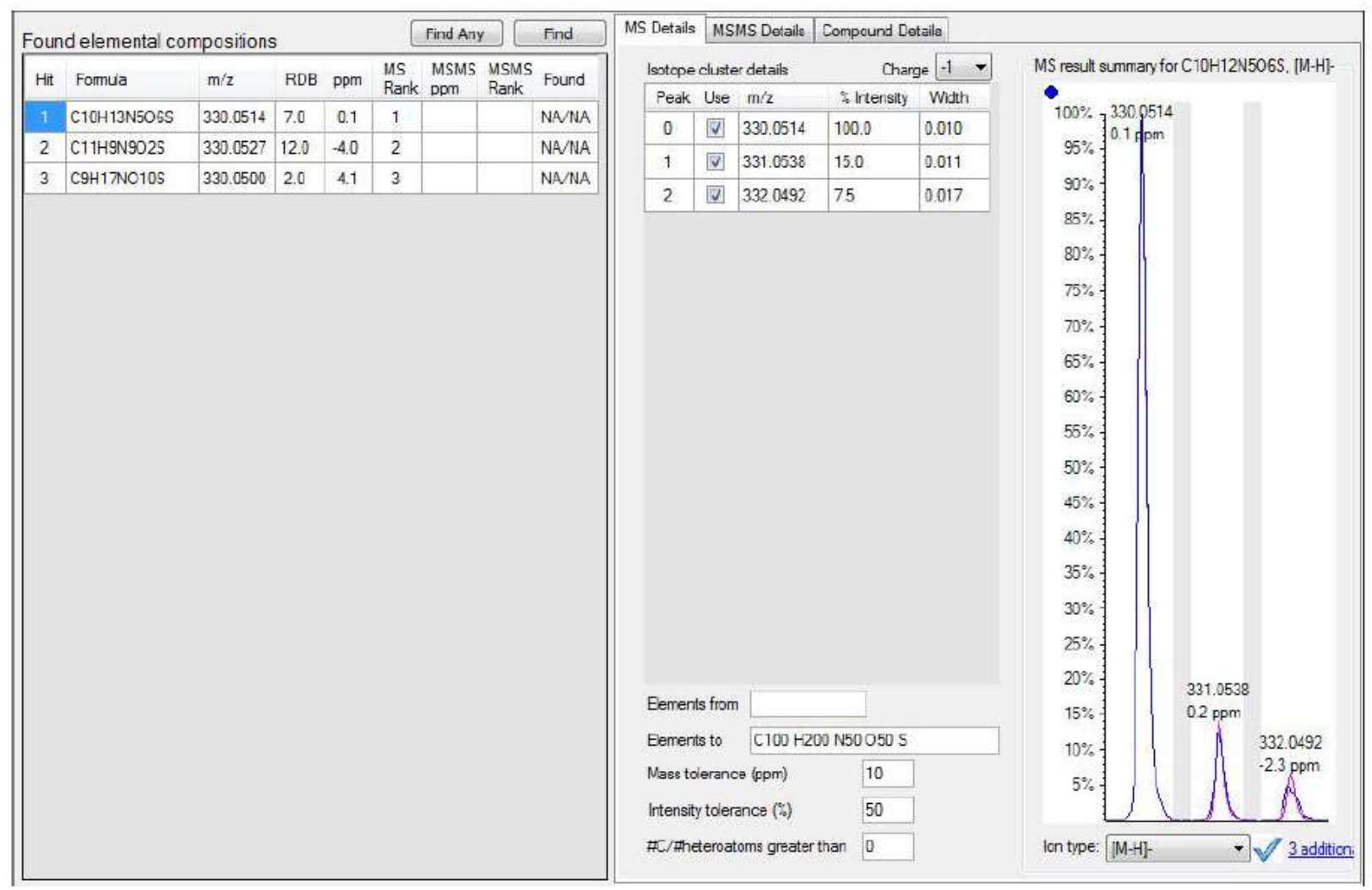

Figure S75. HRESIMS data for 11.

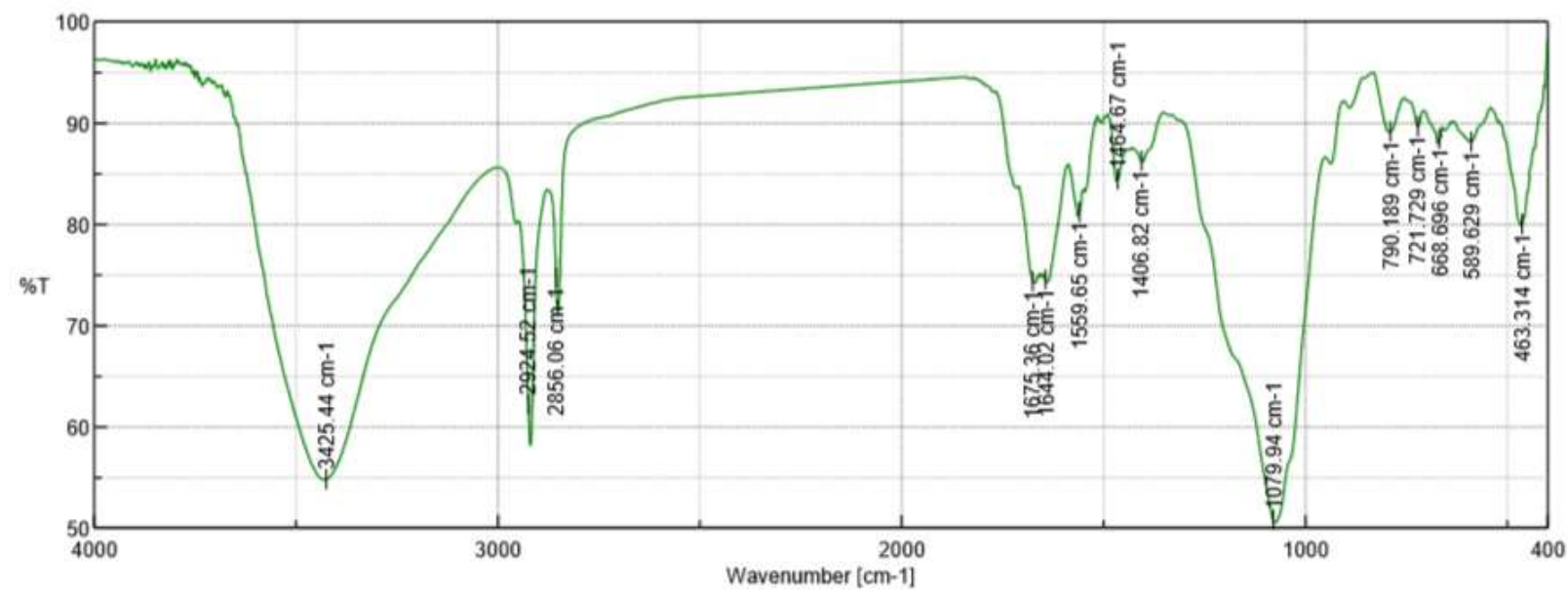

Figure S76. IR spectrum of 11. 


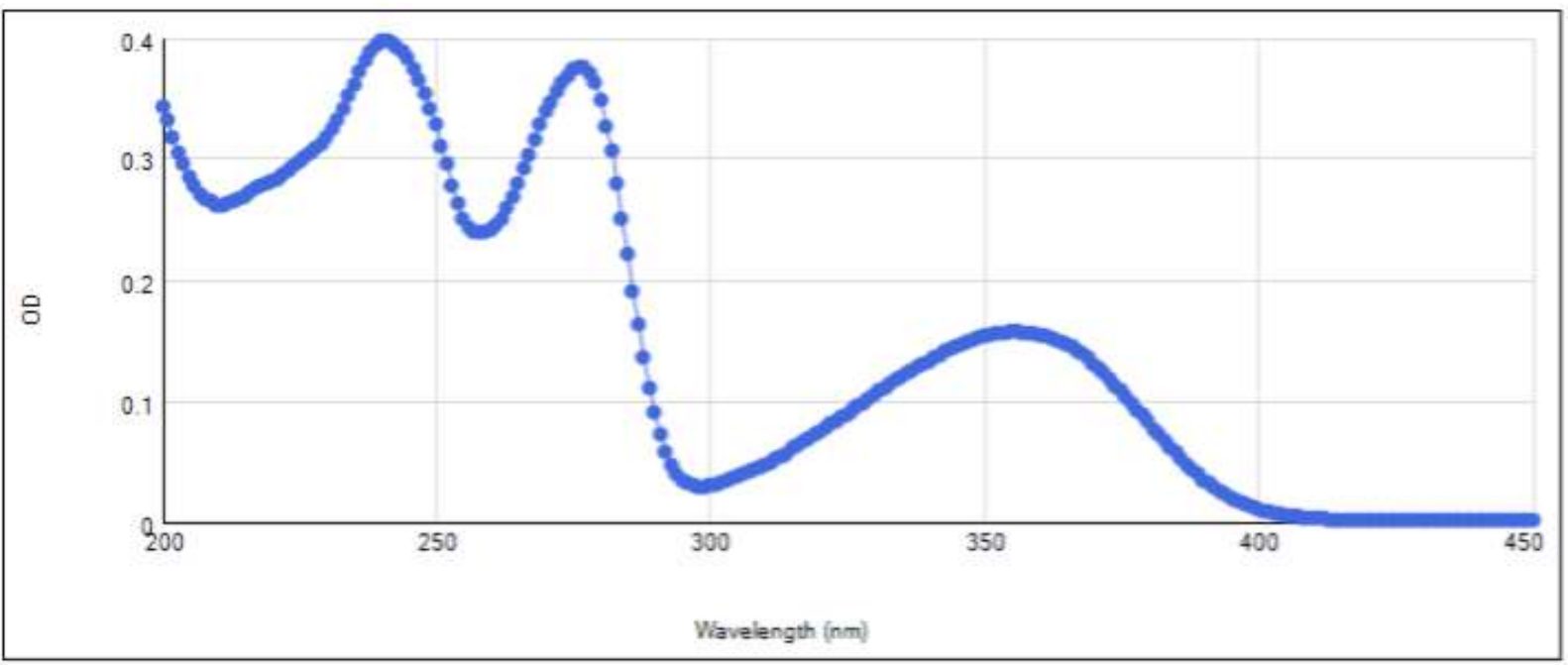

Figure S77. UV spectrum of $\mathbf{1 1 .}$

9
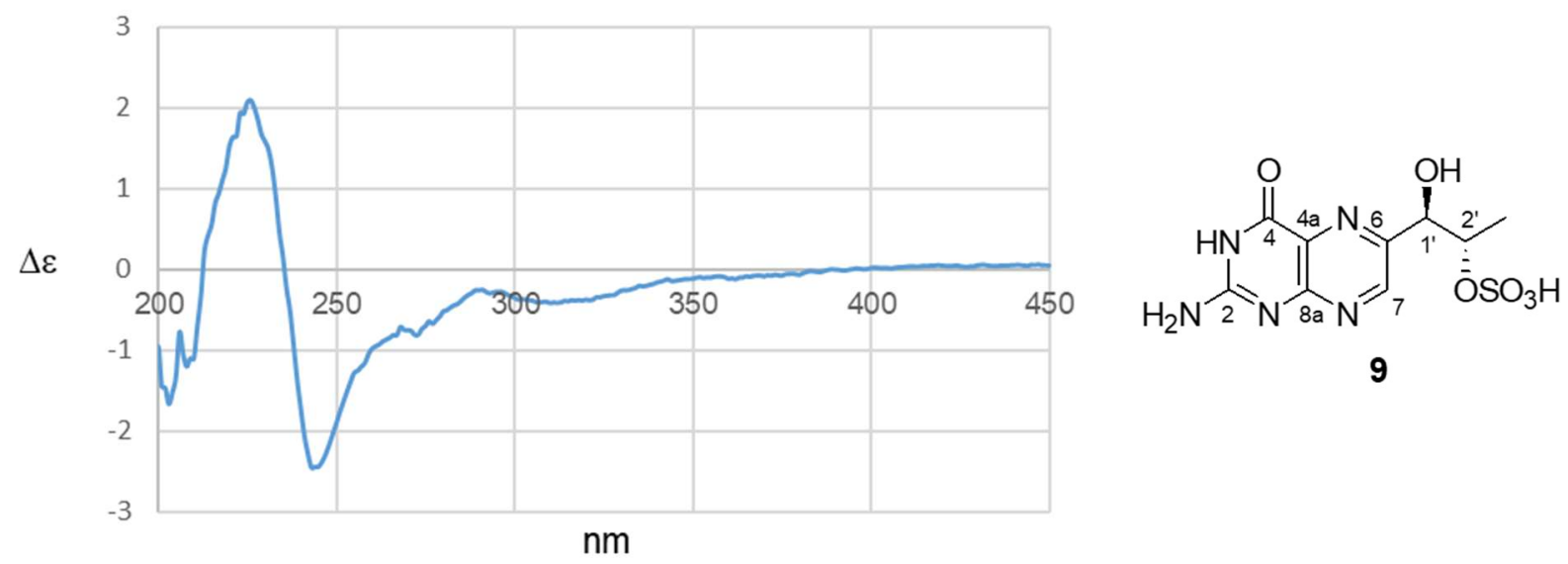

11
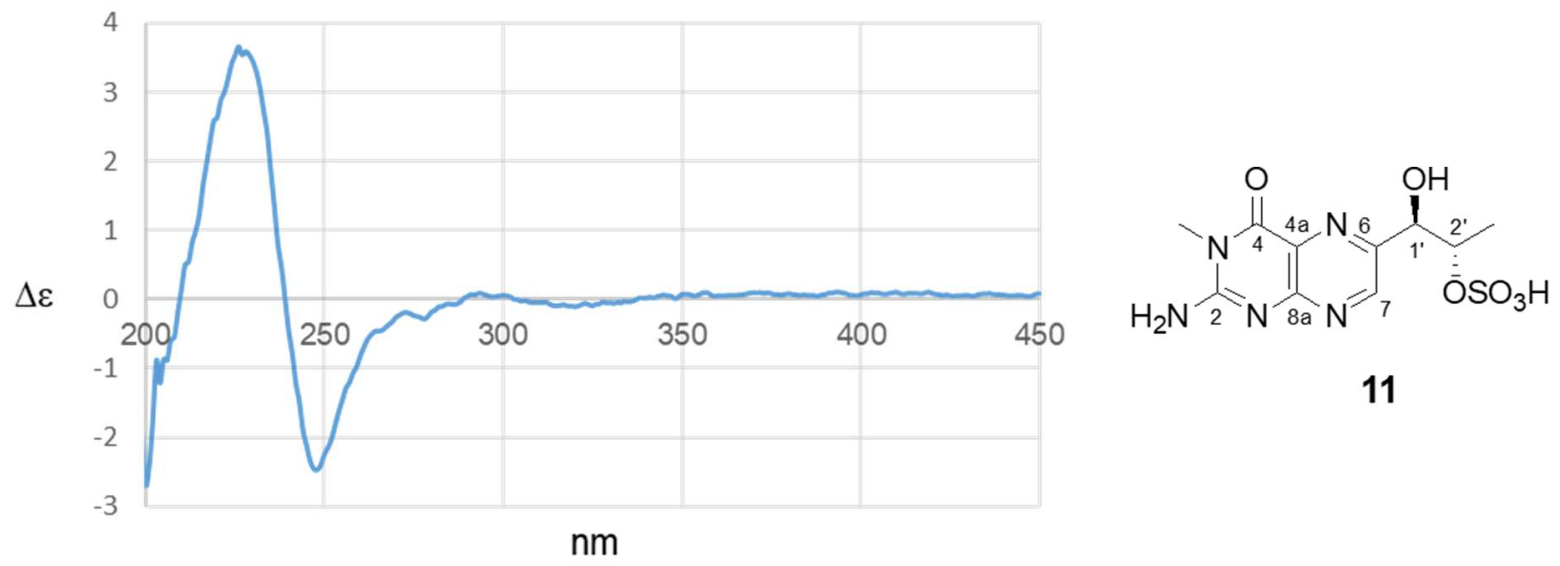

Figure S78. ECD spectra of 9 and 11. 
Table S9. NMR data $\left({ }^{1} \mathrm{H}: 400 \mathrm{MHz},{ }^{13} \mathrm{C}: 100 \mathrm{MHz}\right)$ of 11.

\begin{tabular}{|c|c|c|c|c|c|}
\hline$\# \mathrm{C}$ & $\delta_{\mathrm{C}}$ & $\delta_{\mathrm{H}}$ mult. $(J$ in $\mathrm{Hz})$ & COSY & $\mathrm{HMBC}$ & NOESY \\
\hline 2 & $154.8, \mathrm{C}$ & & & & \\
\hline 3-Me & $30.9, \mathrm{CH}_{3}$ & $3.59, \mathrm{~s}$ & & 2,4 & \\
\hline 4 & $162.1, \mathrm{C}$ & & & & \\
\hline $4 \mathrm{a}$ & $127.1, \mathrm{C}$ & & & & \\
\hline 6 & $154.2, \mathrm{C}$ & & & & \\
\hline 7 & $151.0, \mathrm{CH}$ & $8.91, \mathrm{~s}$ & & $6,8 \mathrm{a}$ & $1^{\prime}, 2^{\prime}, 3^{\prime}$ (vw) \\
\hline $8 \mathrm{a}$ & $149.7, \mathrm{C}$ & & & & \\
\hline $1^{\prime}$ & $75.7, \mathrm{CH}$ & $5.03, \mathrm{~d}(6.0)$ & $2^{\prime}$ & $6,7,2^{\prime}, 3^{\prime}$ & $7,2^{\prime}, 3^{\prime}$ \\
\hline $2^{\prime}$ & $79.8, \mathrm{CH}$ & 4.73 , quin (6.2) & $1^{\prime}, 3^{\prime}$ & $6,2^{\prime}, 3^{\prime}$ & $7,1^{\prime}, 3^{\prime}$ \\
\hline $3^{\prime}$ & $17.1, \mathrm{CH}_{3}$ & $1.37, \mathrm{~d}(6.4)$ & $2^{\prime}$ & $1^{\prime}, 2^{\prime}$ & 7 (vw), 1', 2' \\
\hline
\end{tabular}

Measured at $323 \mathrm{~K}$ in $\mathrm{D}_{2} \mathrm{O}$ with $10 \mu \mathrm{L} \mathrm{CD} \mathrm{CDD}_{3} \mathrm{Os}$ internal standard $\left(\delta_{\mathrm{H}} 3.30, \delta_{\mathrm{C}} 49.15 \mathrm{ppm}\right)$.

$\mathrm{vw}=$ very weak signal.

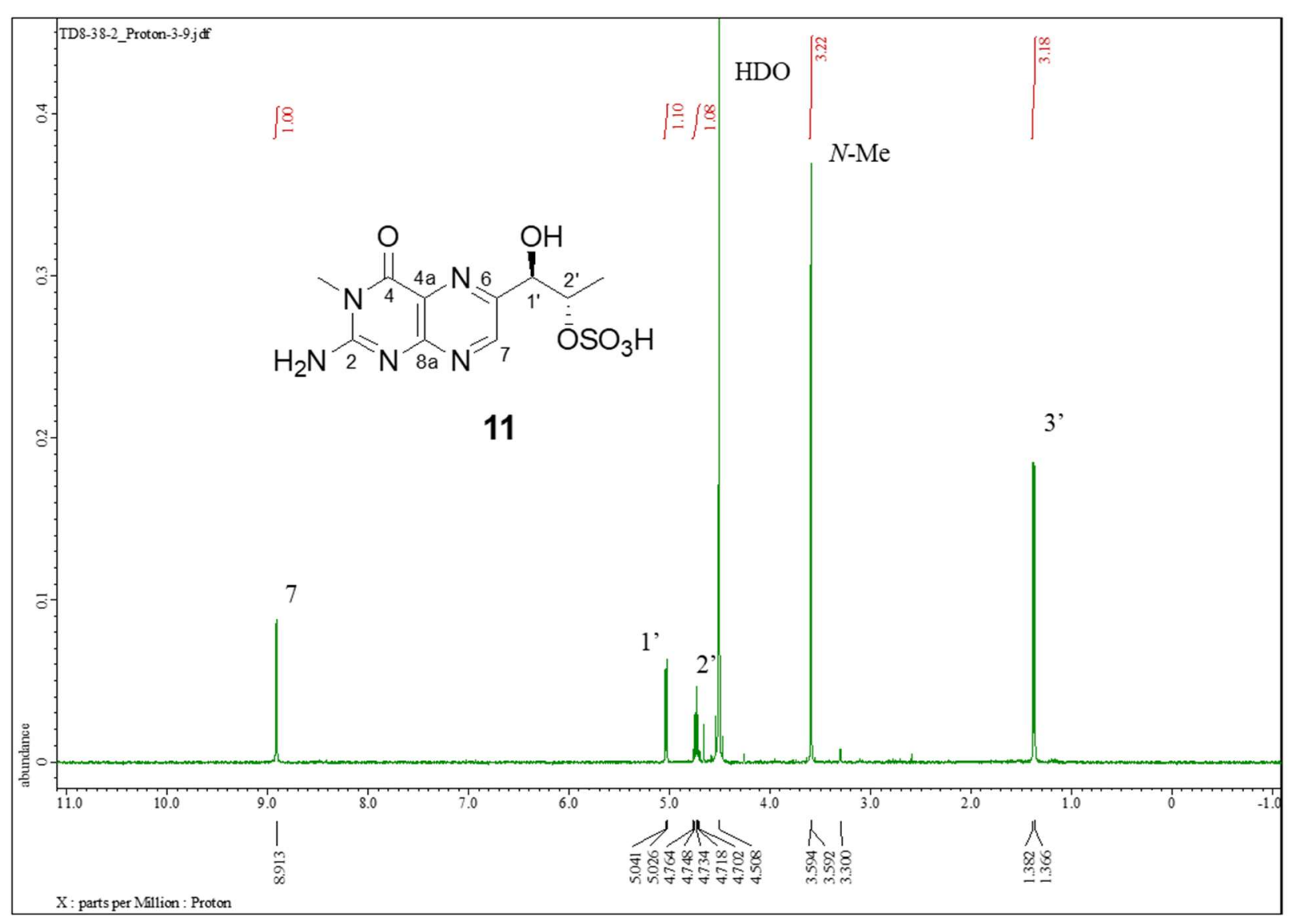

Figure S79. ${ }^{1} \mathrm{H}$ NMR spectrum of 11 in $\mathrm{D}_{2} \mathrm{O}$ with $10 \mu \mathrm{L} \mathrm{CD}_{3} \mathrm{OD}$ at $323 \mathrm{~K}(400 \mathrm{MHz})$. 


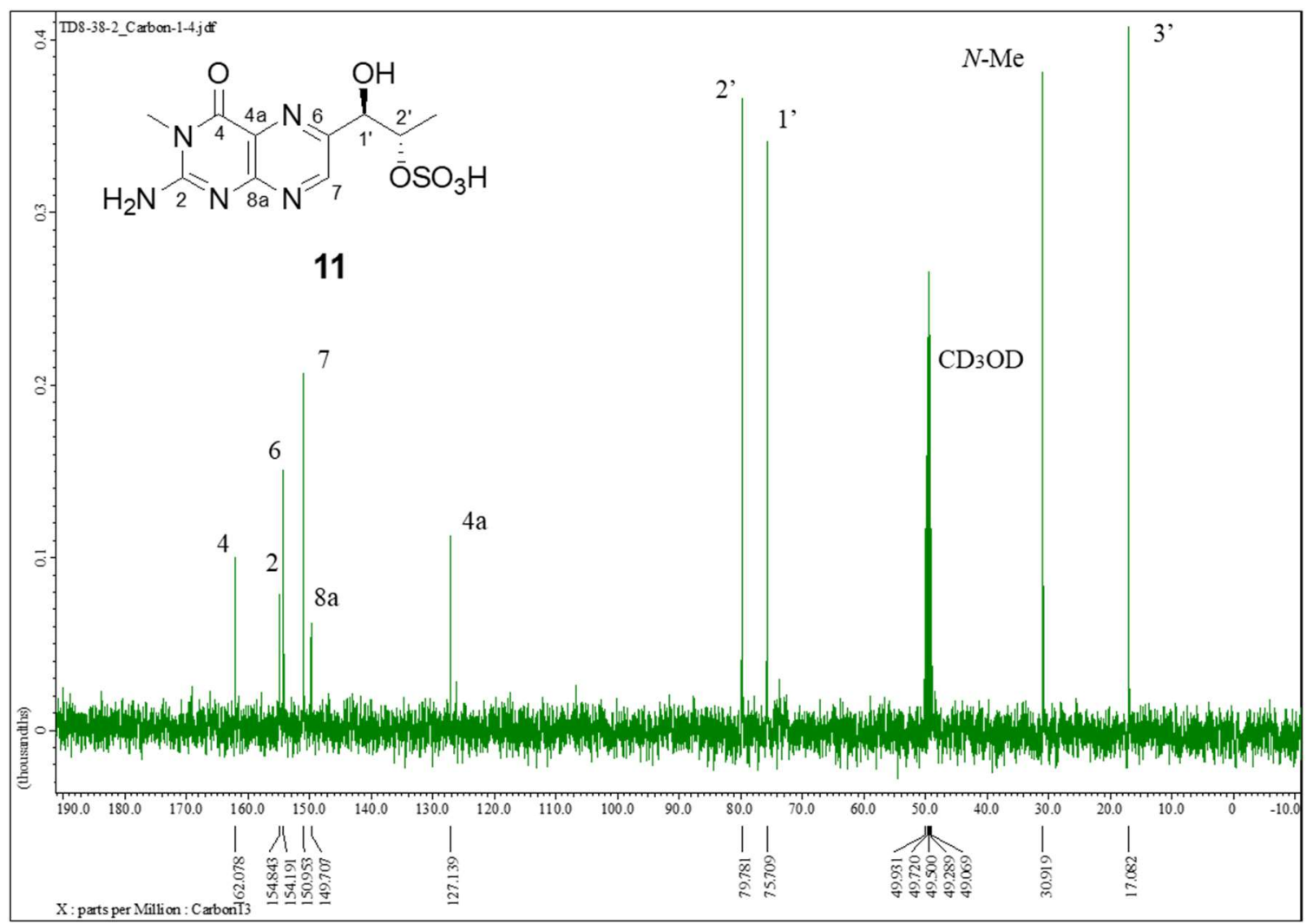

Figure S80. ${ }^{13} \mathrm{C}$ NMR spectrum of 11 in $\mathrm{D}_{2} \mathrm{O}$ with $10 \mu \mathrm{L} \mathrm{CD}{ }_{3} \mathrm{OD}$ at $323 \mathrm{~K}(100 \mathrm{MHz})$.

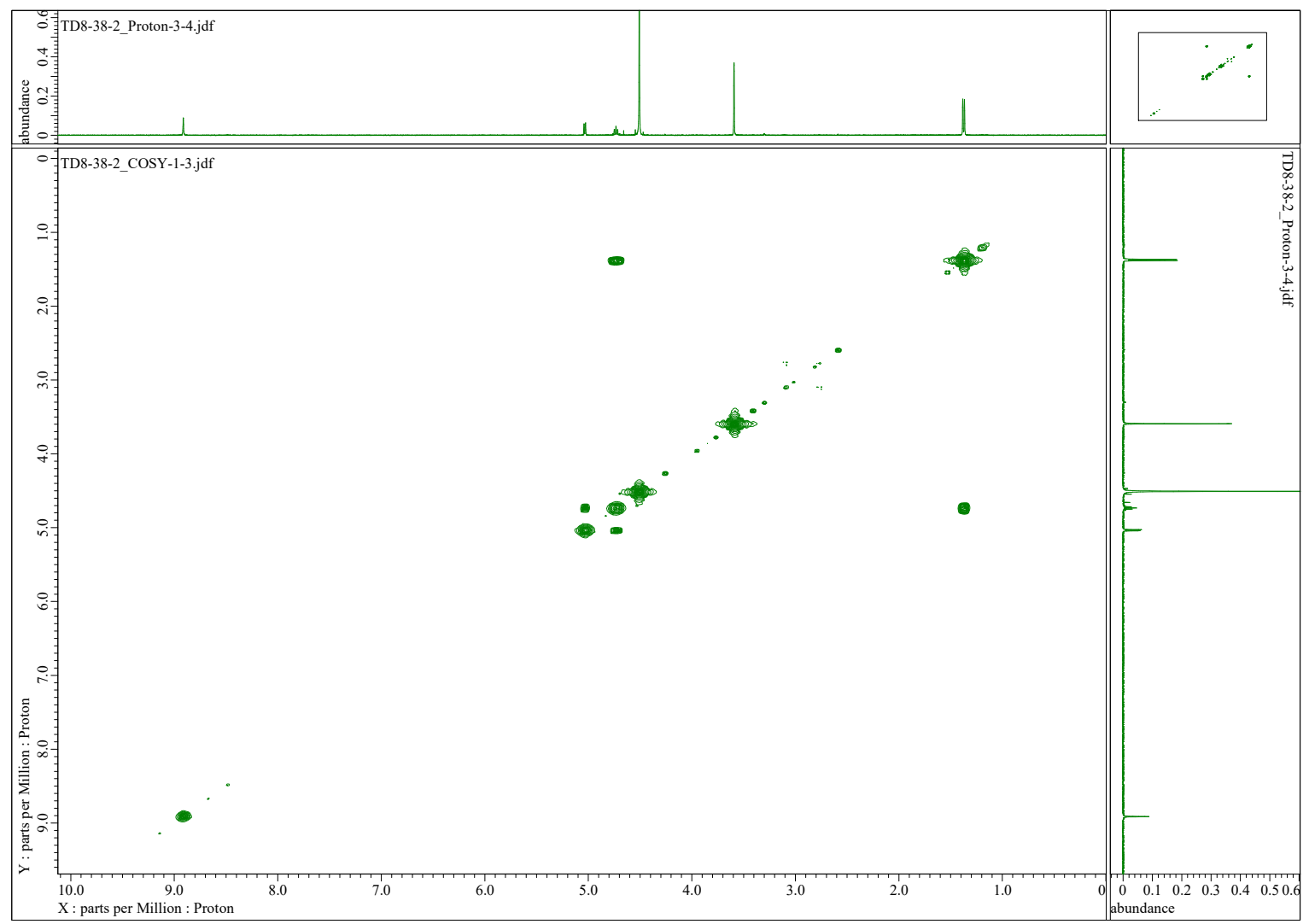

Figure S81. COSY spectrum of $\mathbf{1 1}$ in $\mathrm{D}_{2} \mathrm{O}$ with $10 \mu \mathrm{L} \mathrm{CD}_{3} \mathrm{OD}$. 


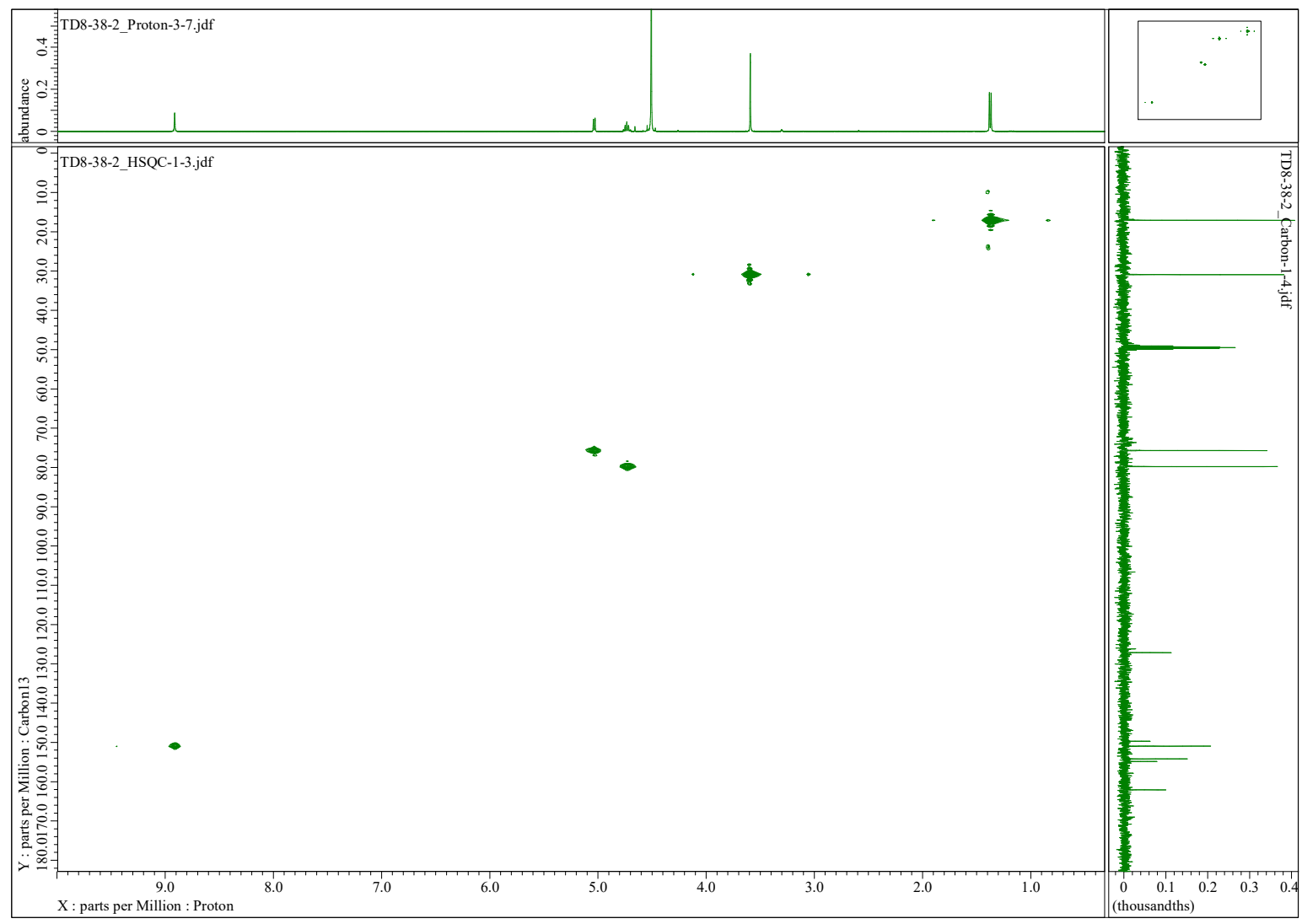

Figure S82. HSQC spectrum of $\mathbf{1 1}$ in $\mathrm{D}_{2} \mathrm{O}$ with $10 \mu \mathrm{L} \mathrm{CD}_{3} \mathrm{OD}$.

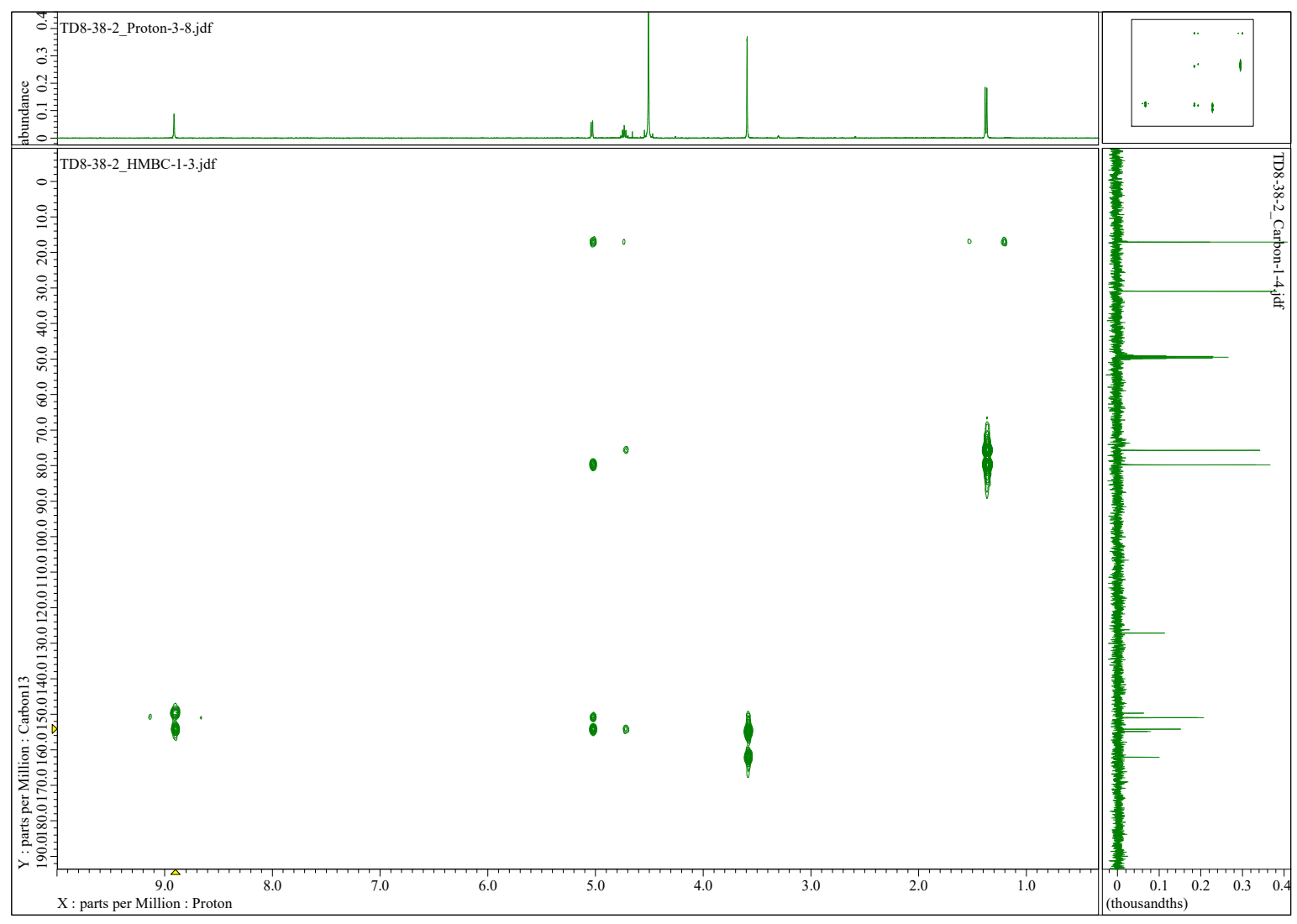

Figure S83. $\mathrm{HMBC}$ spectrum of 11 in $\mathrm{D}_{2} \mathrm{O}$ with $10 \mu \mathrm{L} \mathrm{CD}_{3} \mathrm{OD}$. 


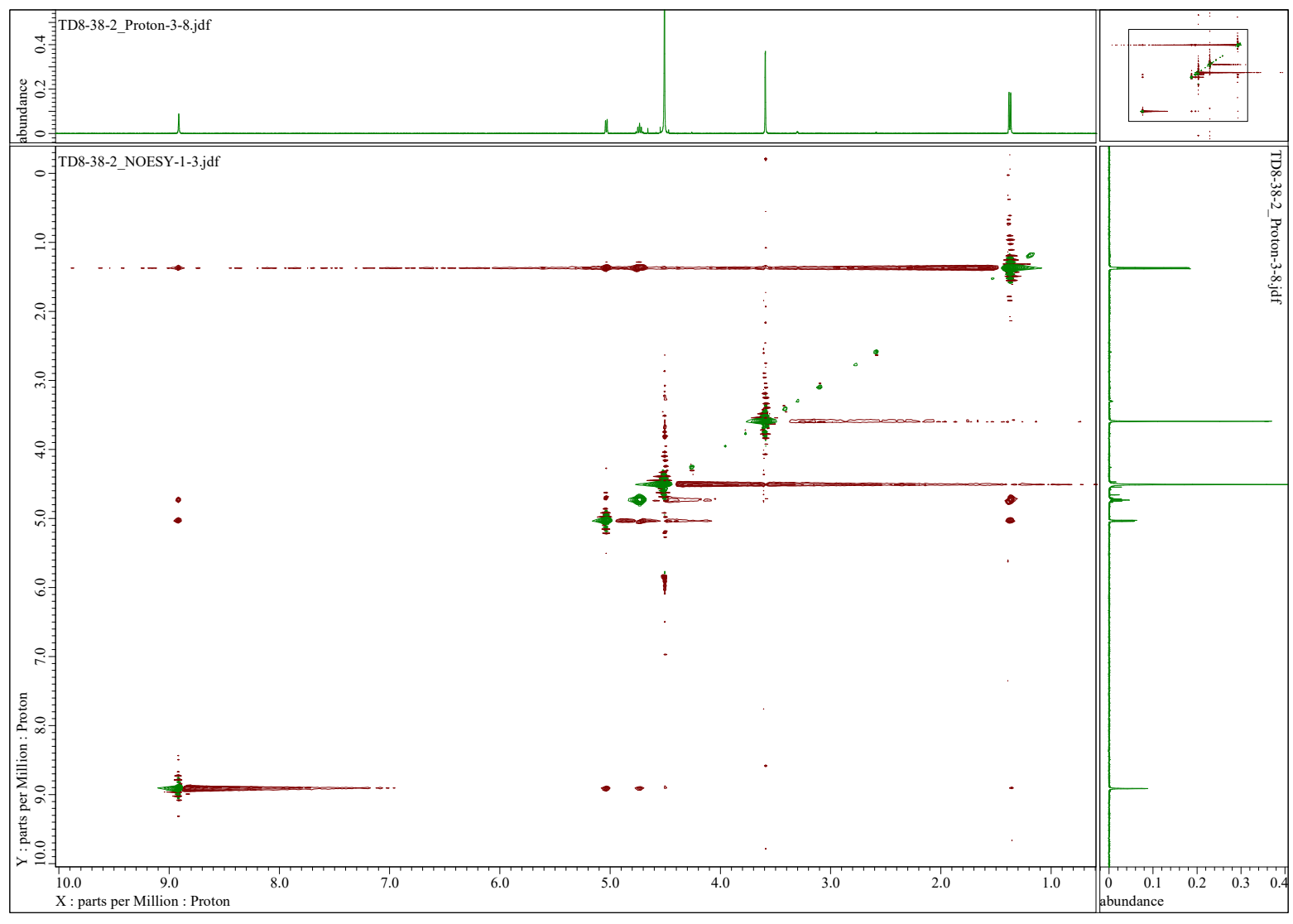

Figure S84. NOESY spectrum of 11 in $\mathrm{D}_{2} \mathrm{O}$ with $10 \mu \mathrm{L} \mathrm{CD} \mathrm{CD}_{3} \mathrm{OD}$. 
3.7. Spectral data and NMR assignments for $\mathbf{1 2}$ and triacetate $\mathbf{1 2 a}$.

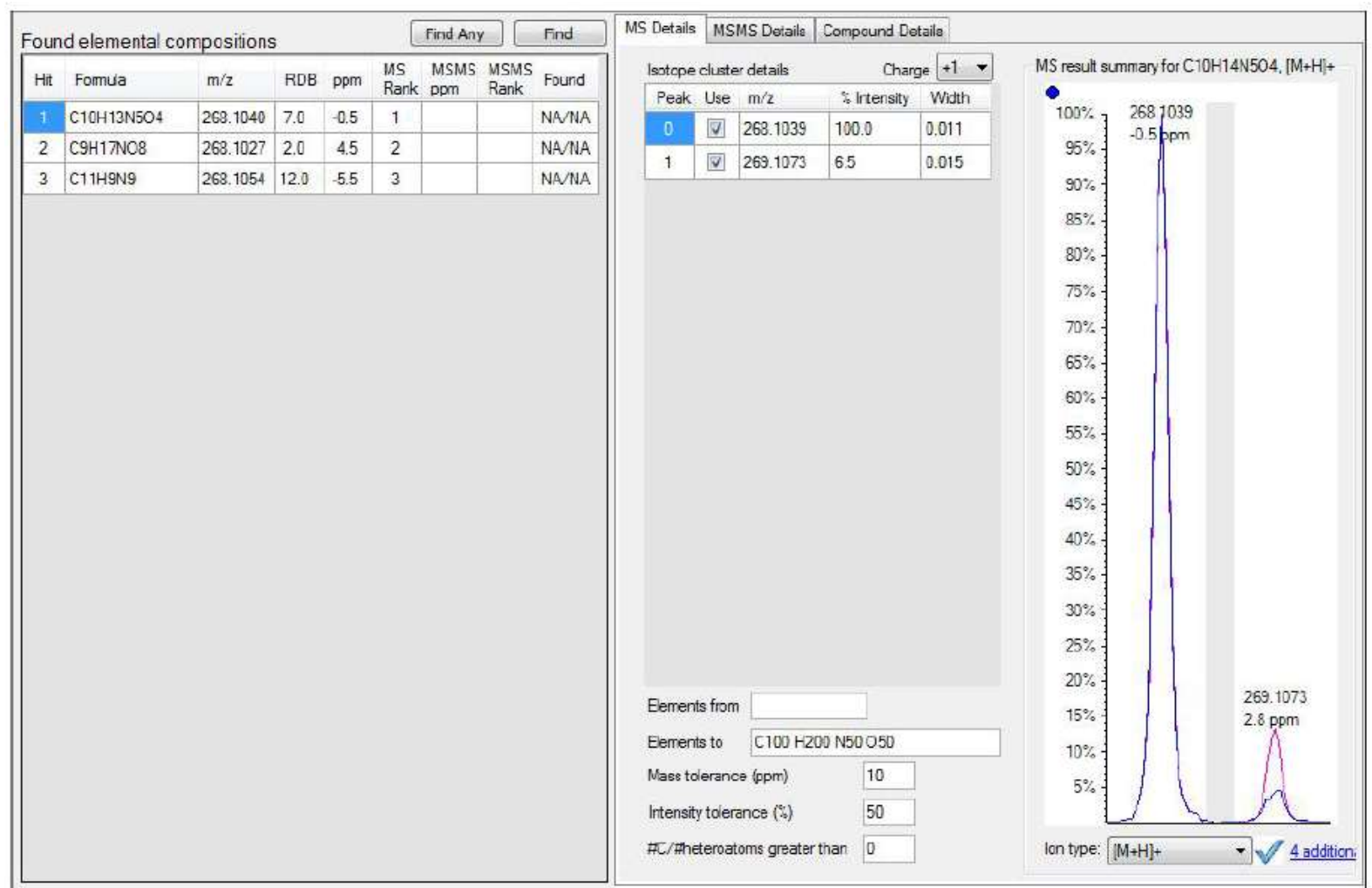

Figure S85. HRESIMS data for 12.

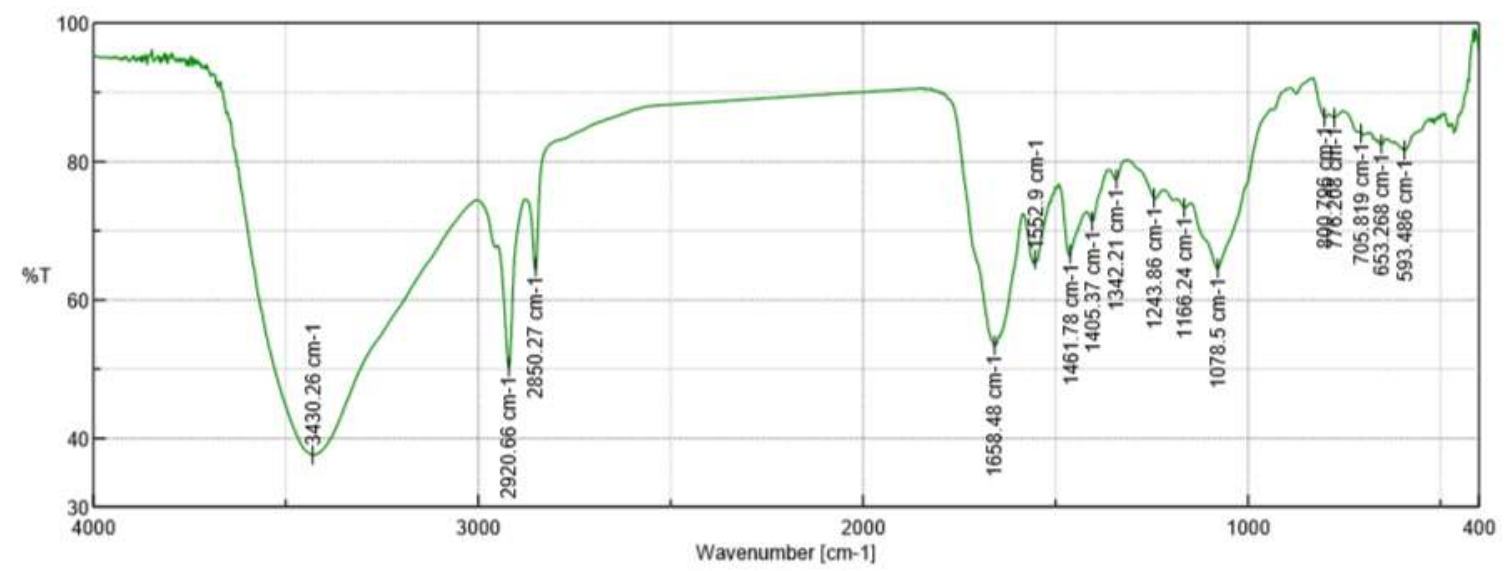

Figure S86. IR spectrum of 12. 


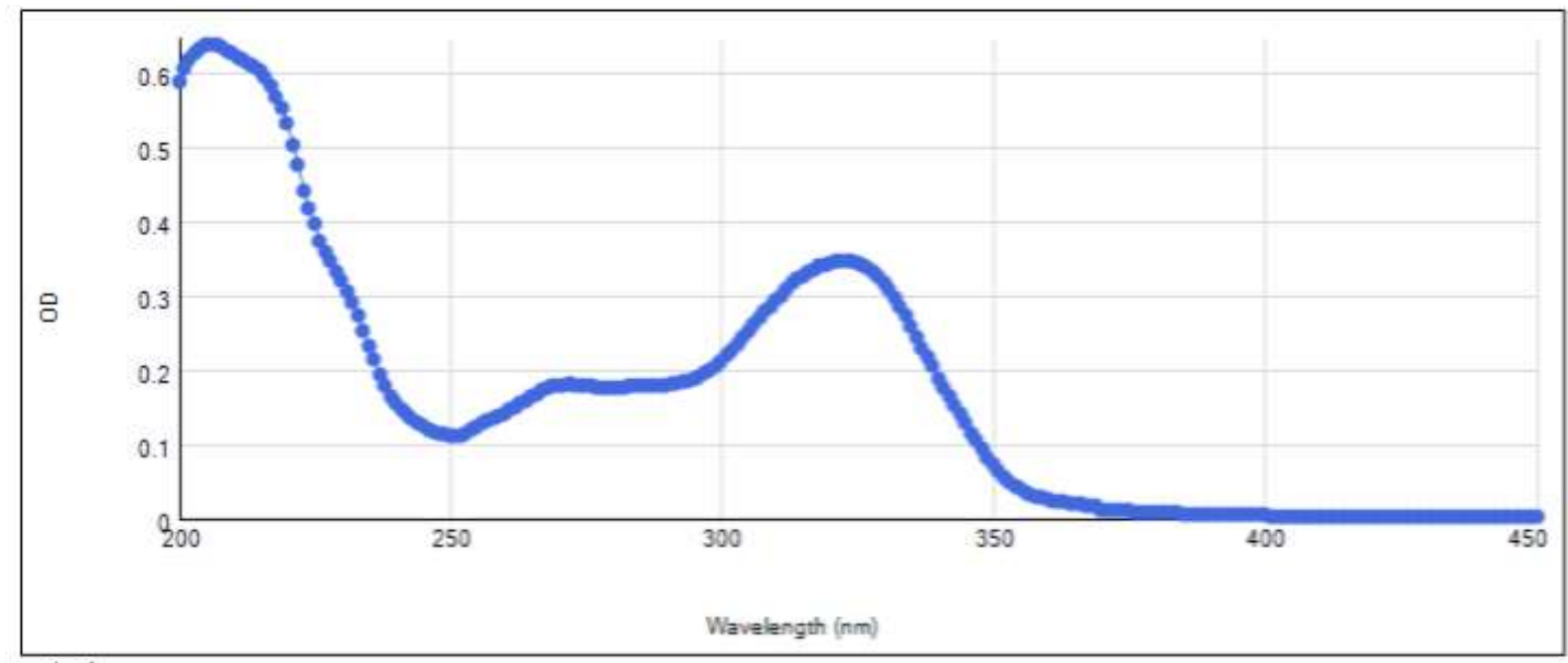

Figure S87. UV spectrum of $\mathbf{1 2}$ in $0.01 \mathrm{M}$ hydrochloric acid

12

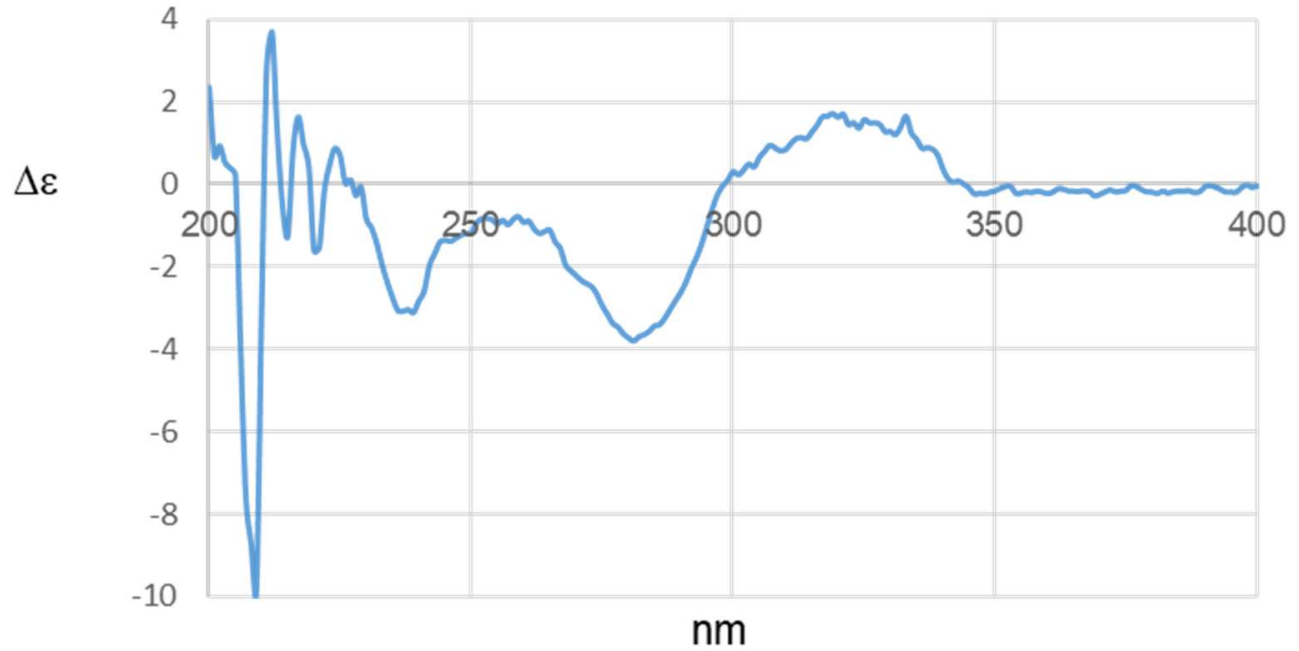

Figure S88. ECD spectrum of $\mathbf{1 2 .}$ 
Table S10. NMR data $\left({ }^{1} \mathrm{H}: 400 \mathrm{MHz},{ }^{13} \mathrm{C}: 100 \mathrm{MHz}\right)$ for 12.

\begin{tabular}{cccccc}
$\# \mathrm{C}$ & $\delta \mathrm{C}$ & $\delta_{\mathrm{H}}$ mult. $(J$ in Hz $)$ & $\mathrm{COSY}$ & HMBC & NOESY \\
\hline $1-\mathrm{Me}$ & $29.7, \mathrm{CH}_{3}$ & $3.55, \mathrm{~s}$ & & $2,8 \mathrm{a}$ & \\
2 & $147.6, \mathrm{C}$ & & & & \\
4 & $158.1, \mathrm{C}$ & & & \\
$4 \mathrm{a}$ & $115.8, \mathrm{C}$ & & & \\
6 & $146.7, \mathrm{C}$ & & & \\
7 & $162.1, \mathrm{C}$ & & & \\
$8 \mathrm{a}$ & $152.3, \mathrm{C}$ & & & & \\
$1^{\prime}$ & $74.6, \mathrm{CH}$ & $4.49, \mathrm{~d}(7.3)$ & $2^{\prime}$ & $6,7,2^{\prime}, 3^{\prime}$ & $2^{\prime}, 3^{\prime}$ \\
$2^{\prime}$ & $68.3, \mathrm{CH}$ & 3.99, quin $(6.6)$ & $1^{\prime}, 3^{\prime}$ & $6,1^{\prime}$ & $1^{\prime}, 3^{\prime}$ \\
$3^{\prime}$ & $19.7, \mathrm{CH} 3$ & $1.11, \mathrm{~d}(6.0)$ & $2^{\prime}$ & $1^{\prime}, 2^{\prime}$ & $1^{\prime}, 2^{\prime}$ \\
\hline
\end{tabular}

Measured at $303 \mathrm{~K}$ in DMSO- $d_{6}$.

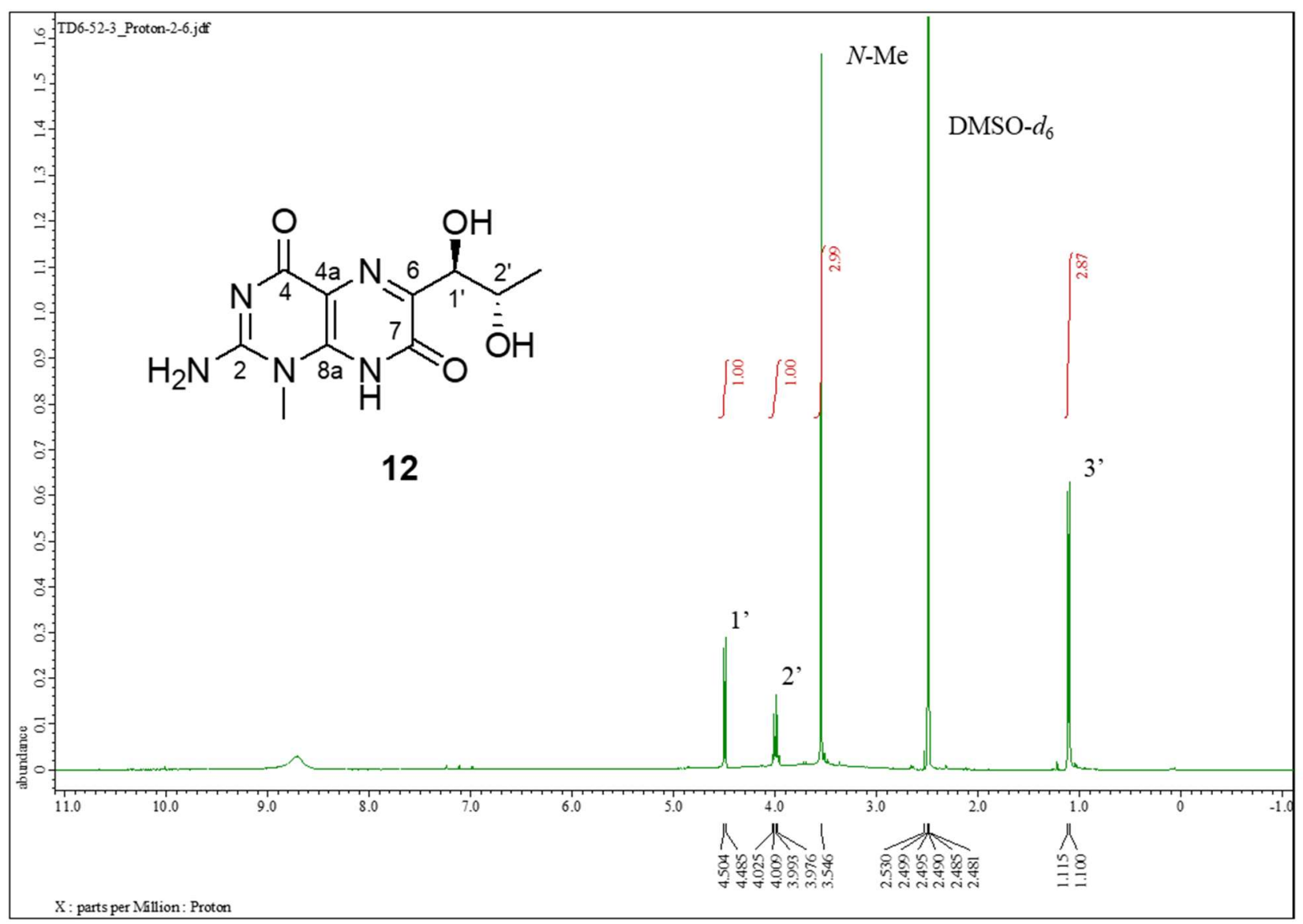

Figure S89. ${ }^{1} \mathrm{H}$ NMR spectrum of $\mathbf{1 2}$ in DMSO- $d_{6}(400 \mathrm{MHz})$. 


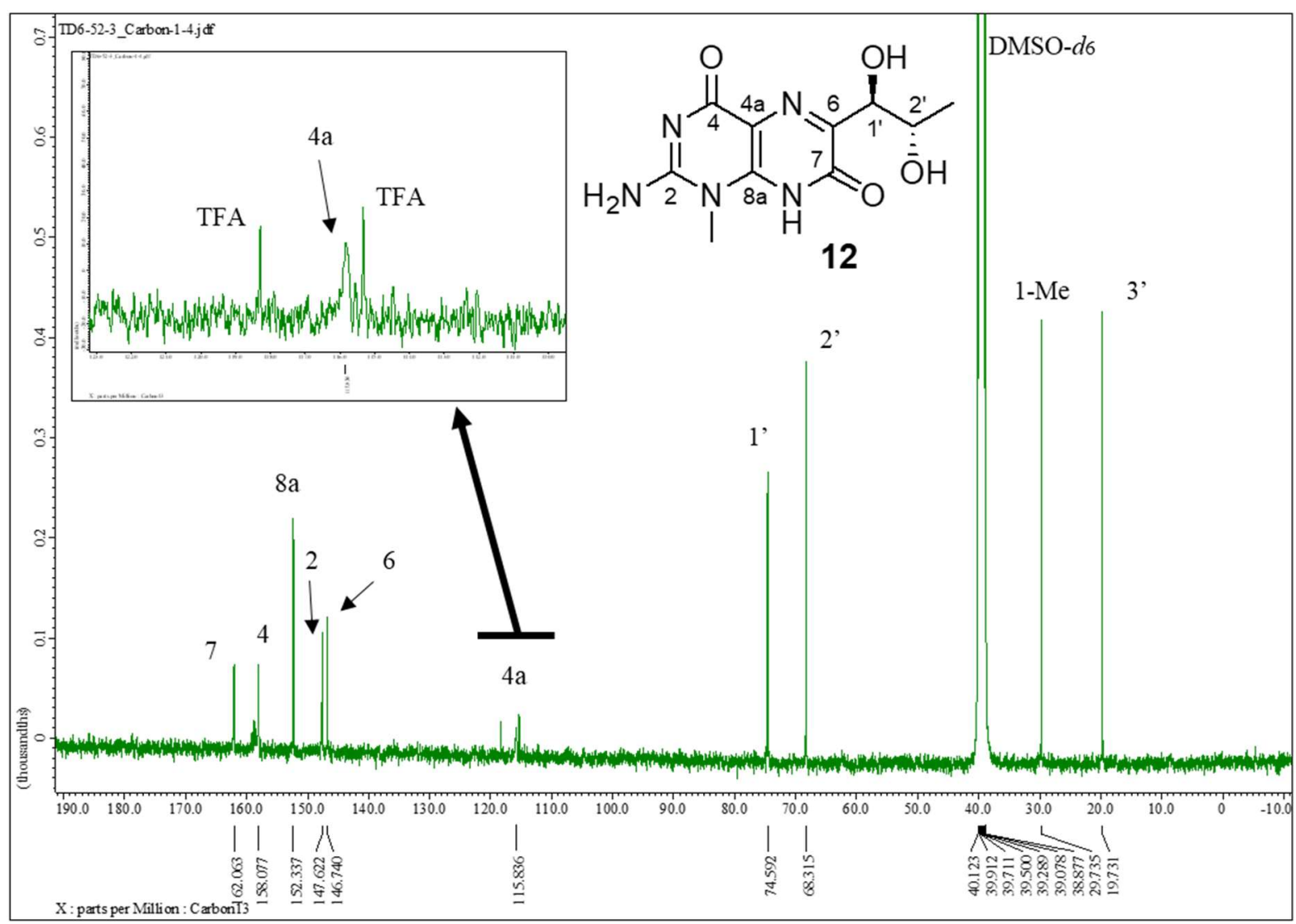

Figure S90. ${ }^{13} \mathrm{C}$ NMR spectrum of 12 in DMSO- $d_{6}(100 \mathrm{MHz})$.

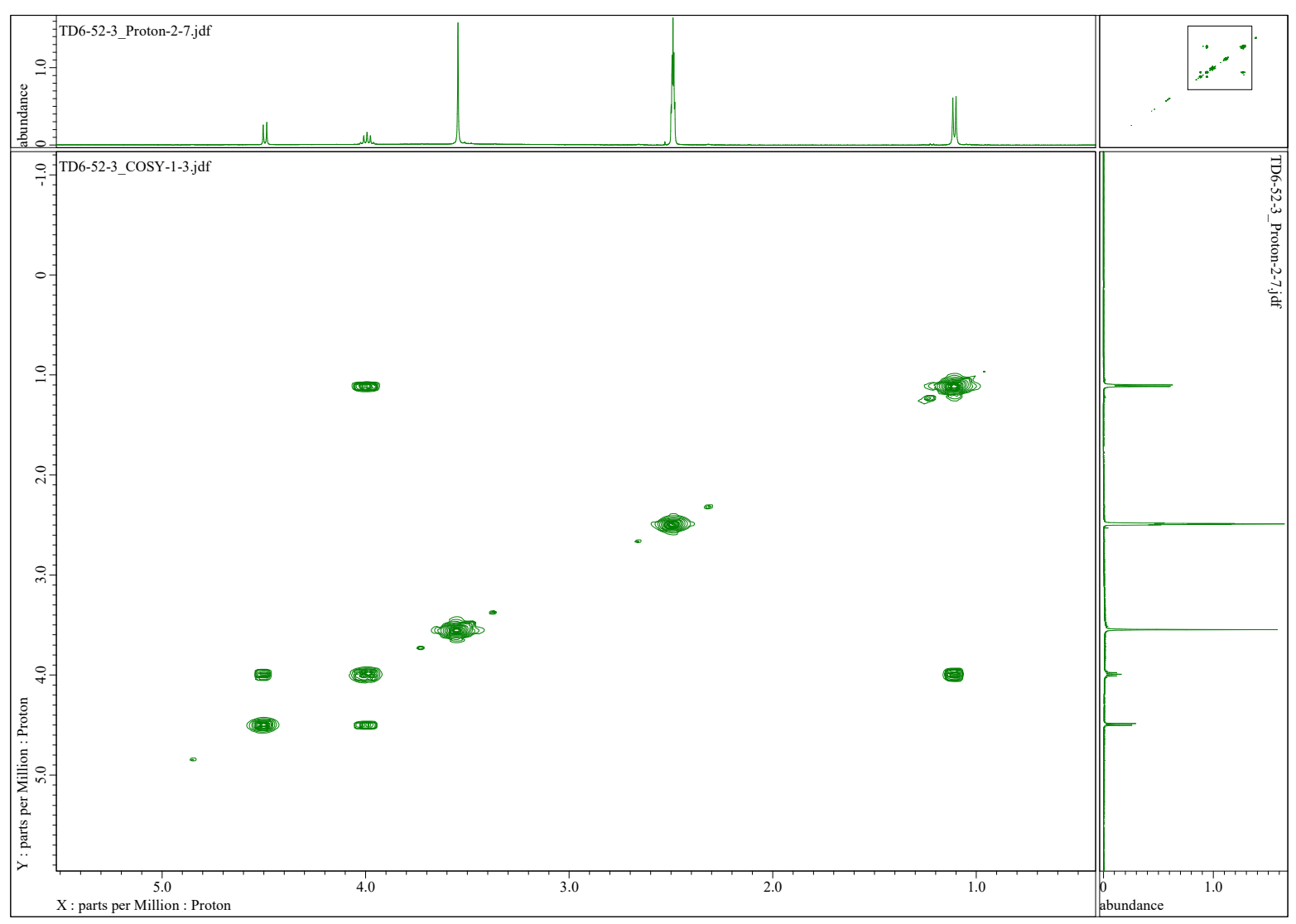

Figure S91. COSY spectrum of 12 in DMSO- $d_{6}$. 


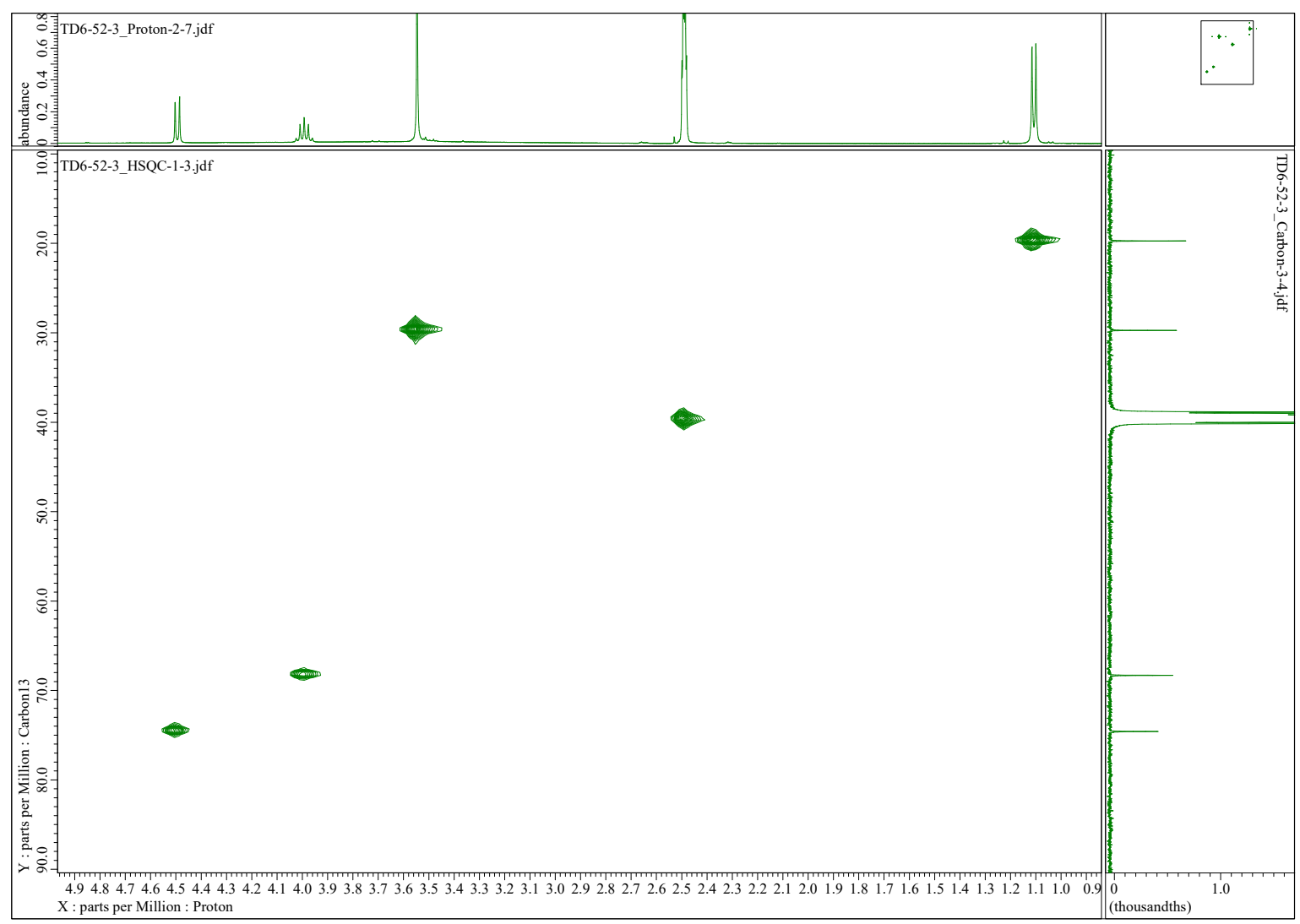

Figure S92. HSQC spectrum of 12 in DMSO- $d_{6}$.

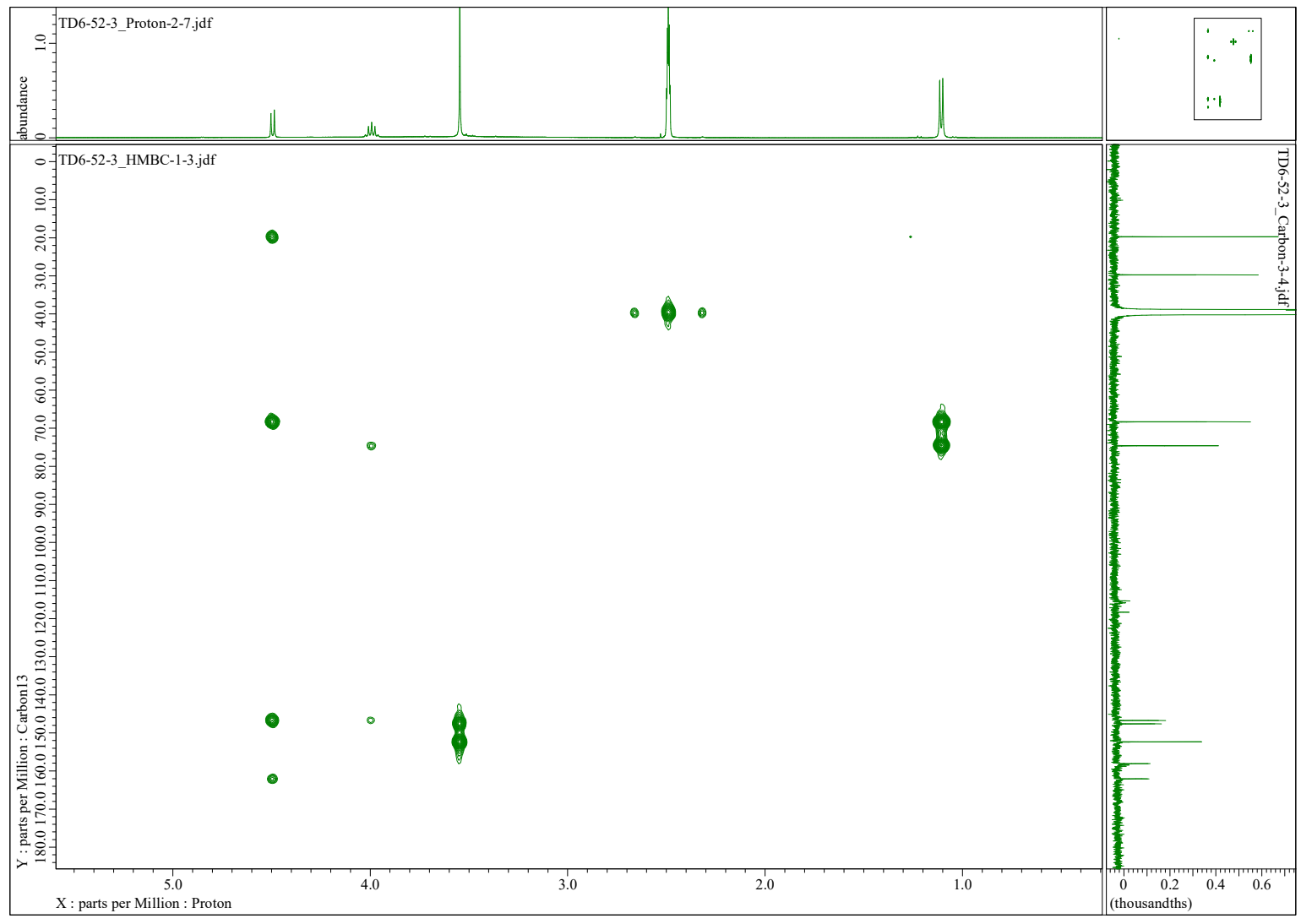

Figure S93. HMBC spectrum of 12 in DMSO- $d_{6}$. 


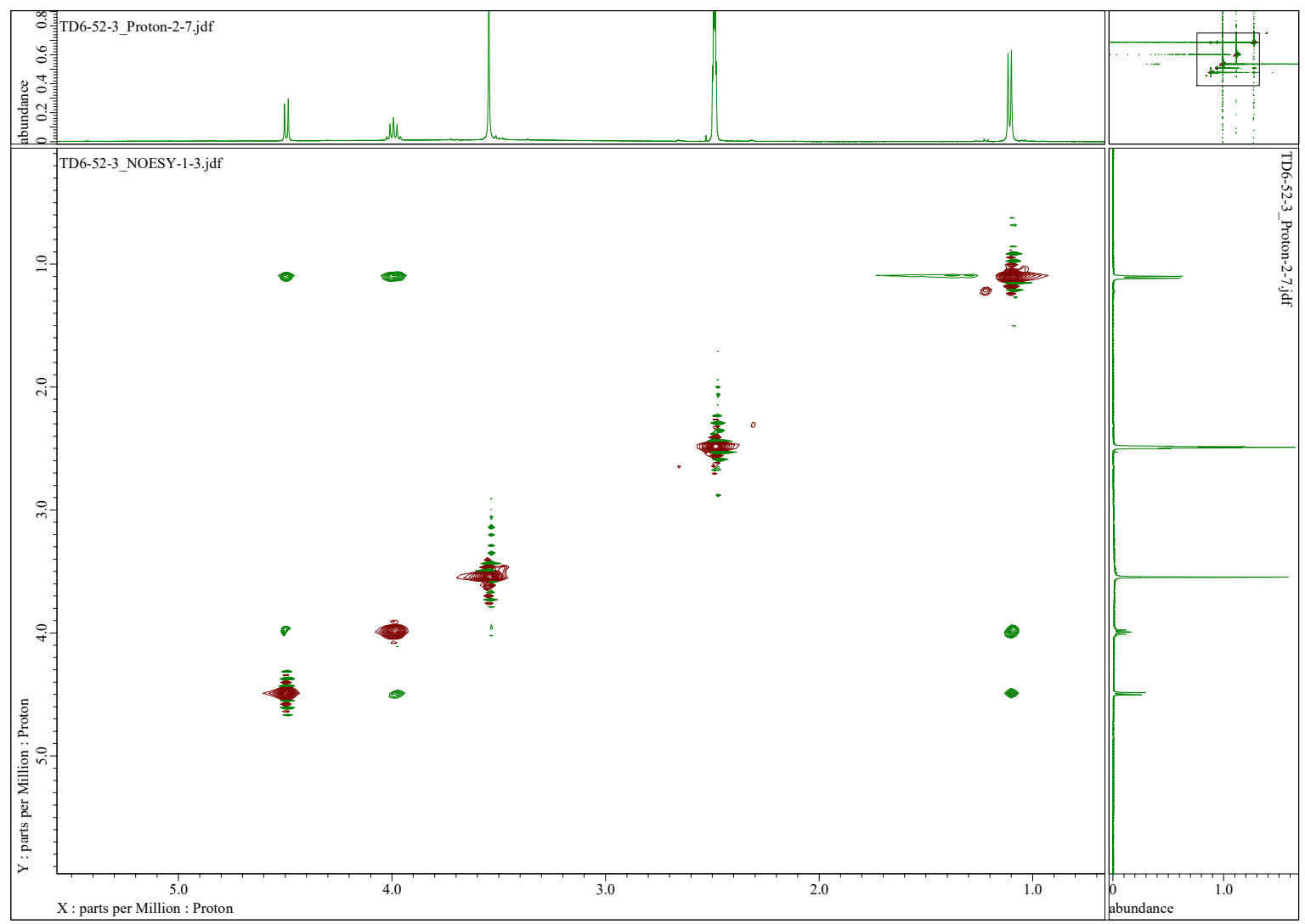

Figure S94. NOESY spectrum of 12 in DMSO- $d_{6}$. 


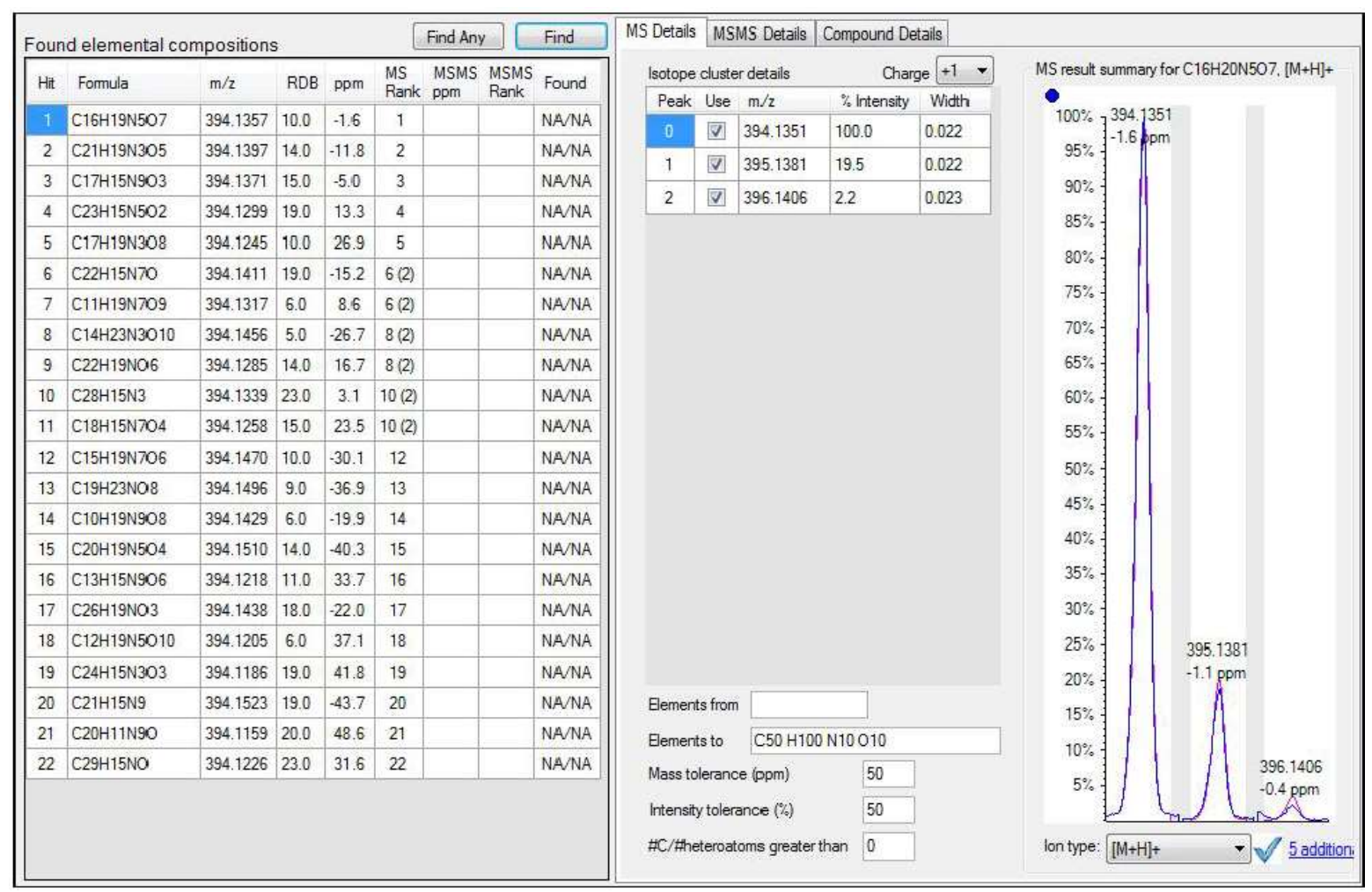

Figure S95. HRESIMS data for acetate 12a.

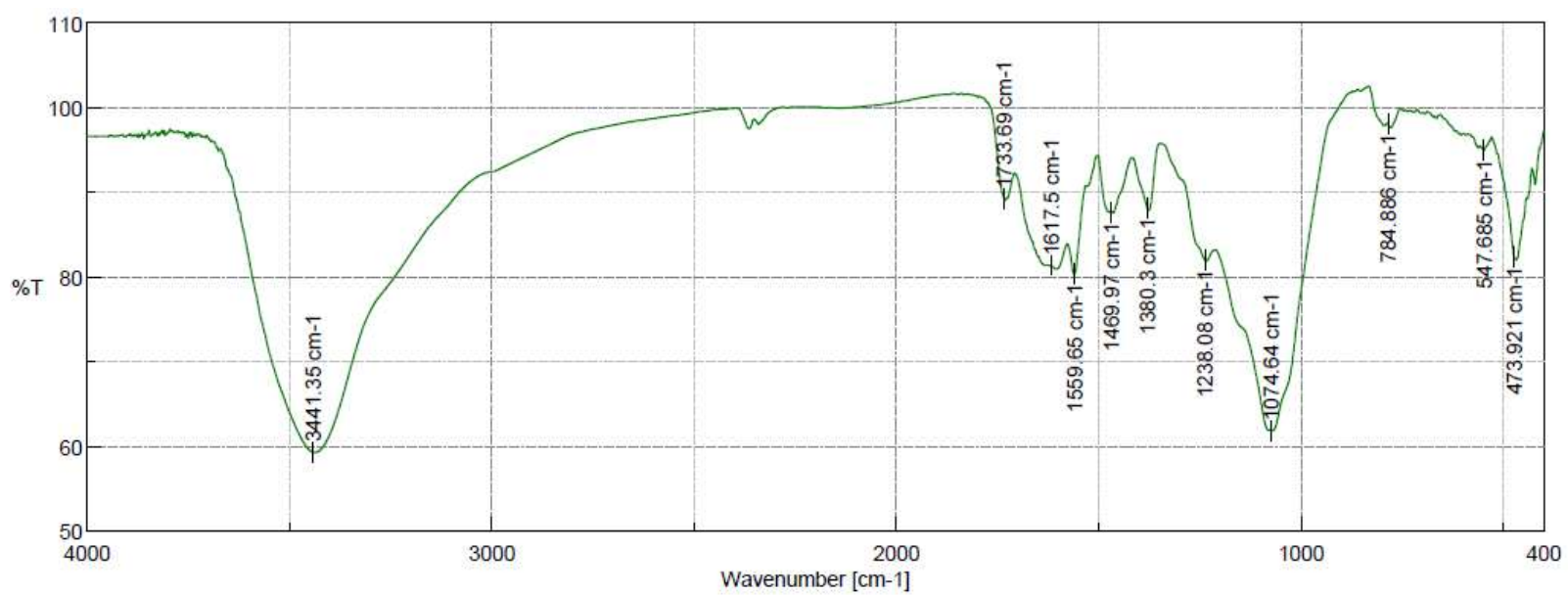

Figure S96. IR spectrum of 12a. 


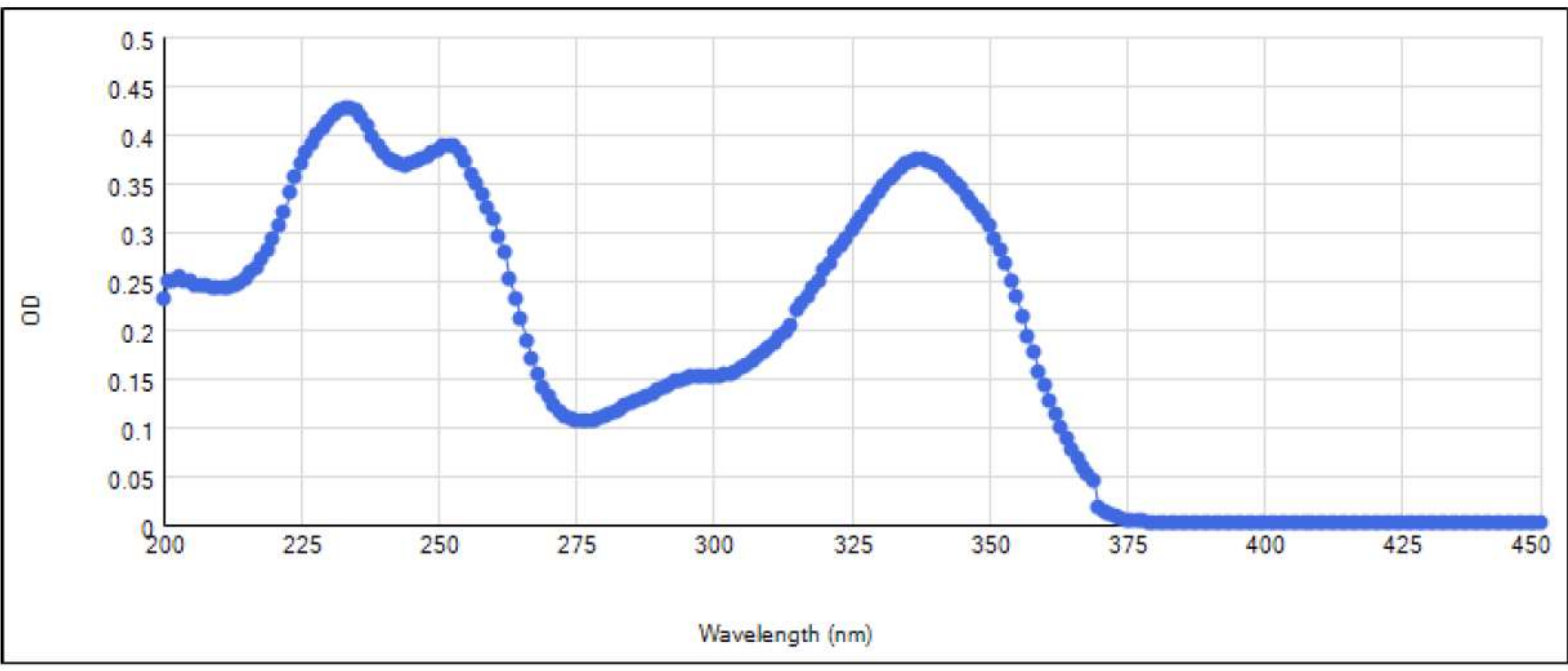

Figure S97. UV spectrum of 12a.

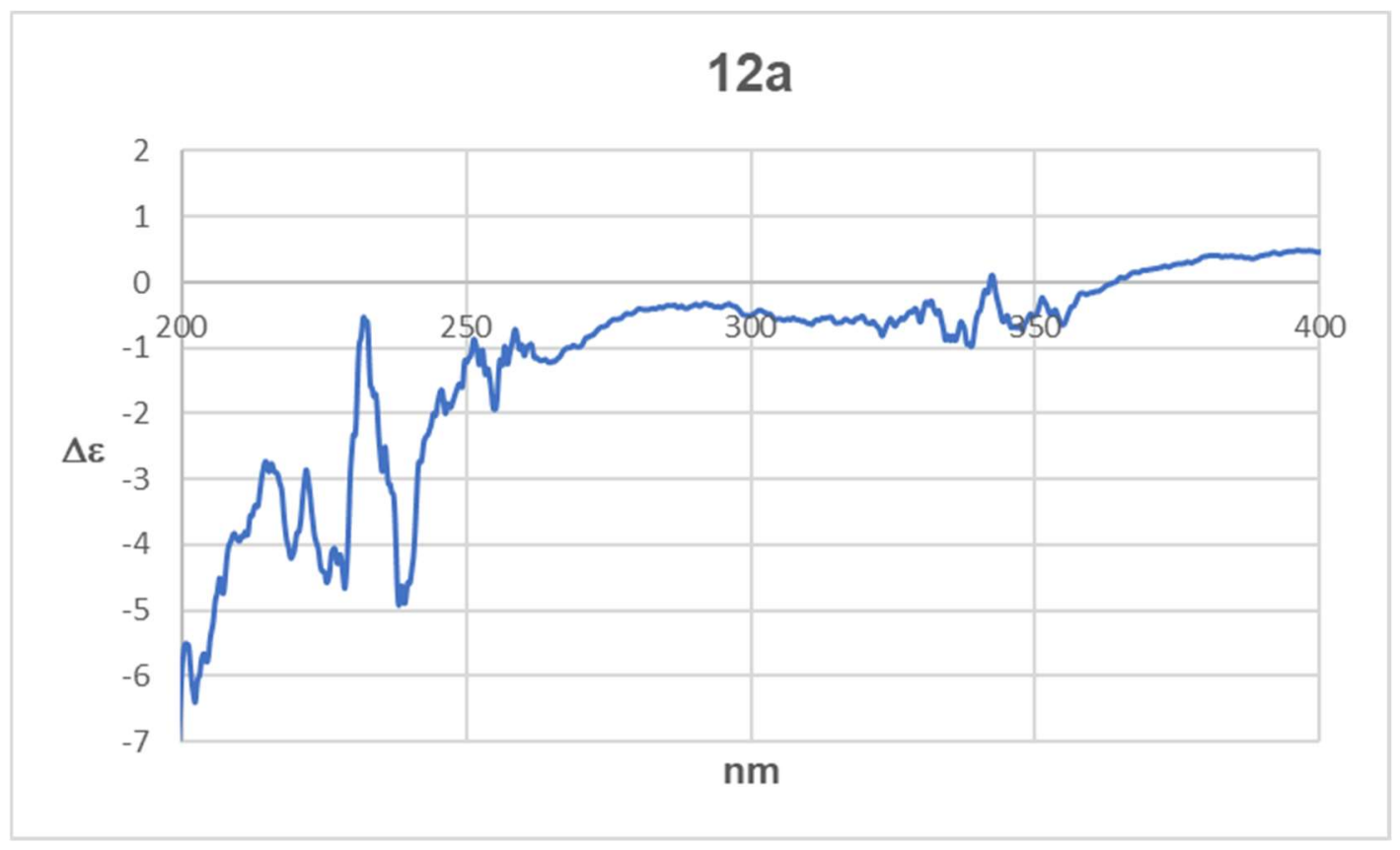

Figure S98. ECD spectrum of 12a in $\mathrm{MeOH}$ at $1 \mathrm{mM}$. 
Table S11. NMR data $\left({ }^{1} \mathrm{H}: 400 \mathrm{MHz},{ }^{13} \mathrm{C}: 100 \mathrm{MHz}\right)$ for $\mathbf{1 2 a}$.

\begin{tabular}{|c|c|c|c|c|c|}
\hline$\# \mathrm{C}$ & $\delta_{\mathrm{C}}$ & $\delta_{\mathrm{H}}$ mult. $(J$ in Hz) & COSY & $\mathrm{HMBC}$ & NOESY \\
\hline 1-Me & $28.9, \mathrm{CH}_{3}$ & $3,48, \mathrm{~s}$ & & $2,8 \mathrm{a}$ & \\
\hline 2 & $152.7, \mathrm{C}^{a}$ & & & & \\
\hline 4 & $156.8, \mathrm{C}$ & & & & \\
\hline 6 & $143.0, \mathrm{C}$ & & & & \\
\hline 7 & 164.6, C & & & & \\
\hline $8 \mathrm{a}$ & $151.7, \mathrm{C}^{a}$ & & & & \\
\hline 9 & $184.2, \mathrm{C}^{c}$ & & & & \\
\hline 10 & $28.6, \mathrm{CH}_{3}{ }^{c}$ & $2.09, \mathrm{~s}$ & & 9 & \\
\hline $1^{\prime}$ & $73.1, \mathrm{CH}$ & $5.97, \mathrm{~d}(3.2)$ & $2^{\prime}$ & $6,2^{\prime}, 3^{\prime}, 4^{\prime}$ & $2^{\prime}, 3^{\prime}$ \\
\hline $2^{\prime}$ & $69.0, \mathrm{CH}$ & $5.34, \mathrm{dq}(6.4,3.5)$ & $1^{\prime}, 3^{\prime}$ & $6^{\prime}$ & $1^{\prime}, 3^{\prime}$ \\
\hline $3^{\prime}$ & $14.3, \mathrm{CH}_{3}$ & $1.12, \mathrm{~d}(6.4)$ & $2^{\prime}$ & $1^{\prime}, 2^{\prime}$ & $1^{\prime}, 2^{\prime}$ \\
\hline $4^{\prime}$ & 169.7, C & & & & \\
\hline $5^{\prime}$ & $21.0, \mathrm{CH}_{3}{ }^{b}$ & $2.07, \mathrm{~s}$ & & $4^{\prime}$ & \\
\hline $6^{\prime}$ & $169.6, \mathrm{C}$ & & & & \\
\hline $7^{\prime}$ & $21.0, \mathrm{CH}_{3}{ }^{b}$ & $1.97, \mathrm{~s}$ & & $6^{\prime}$ & \\
\hline
\end{tabular}

Measured at $276 \mathrm{~K}$ in DMSO- $d_{6} .{ }^{a}$ ), ${ }^{b}$ ) Interchangeable. ${ }^{c}$ Too much deshielding at C-9 $\left(\delta_{\mathrm{C}} 184.2\right)$ and $\mathrm{C}-10\left(\delta_{\mathrm{C}} 28.6\right)$ thought to be caused by formation of a hydrogen bond between C-9 carbonyl oxygen and NH-3 proton (Figure S99).

A<smiles>CC(=O)Nc1nc(=O)c2nc([C@@H](OC(C)=O)[C@@H](C)OC(C)=O)c(=O)[nH]c2n1C</smiles>

B<smiles>CC(=O)N=c1[nH]c(=O)c2nc([C@H](OC(C)=O)[C@H](C)OC(C)=O)c(=O)[nH]c2n1C</smiles>

Figure S99. Proposed tautomeric forms of acetate 12a. 


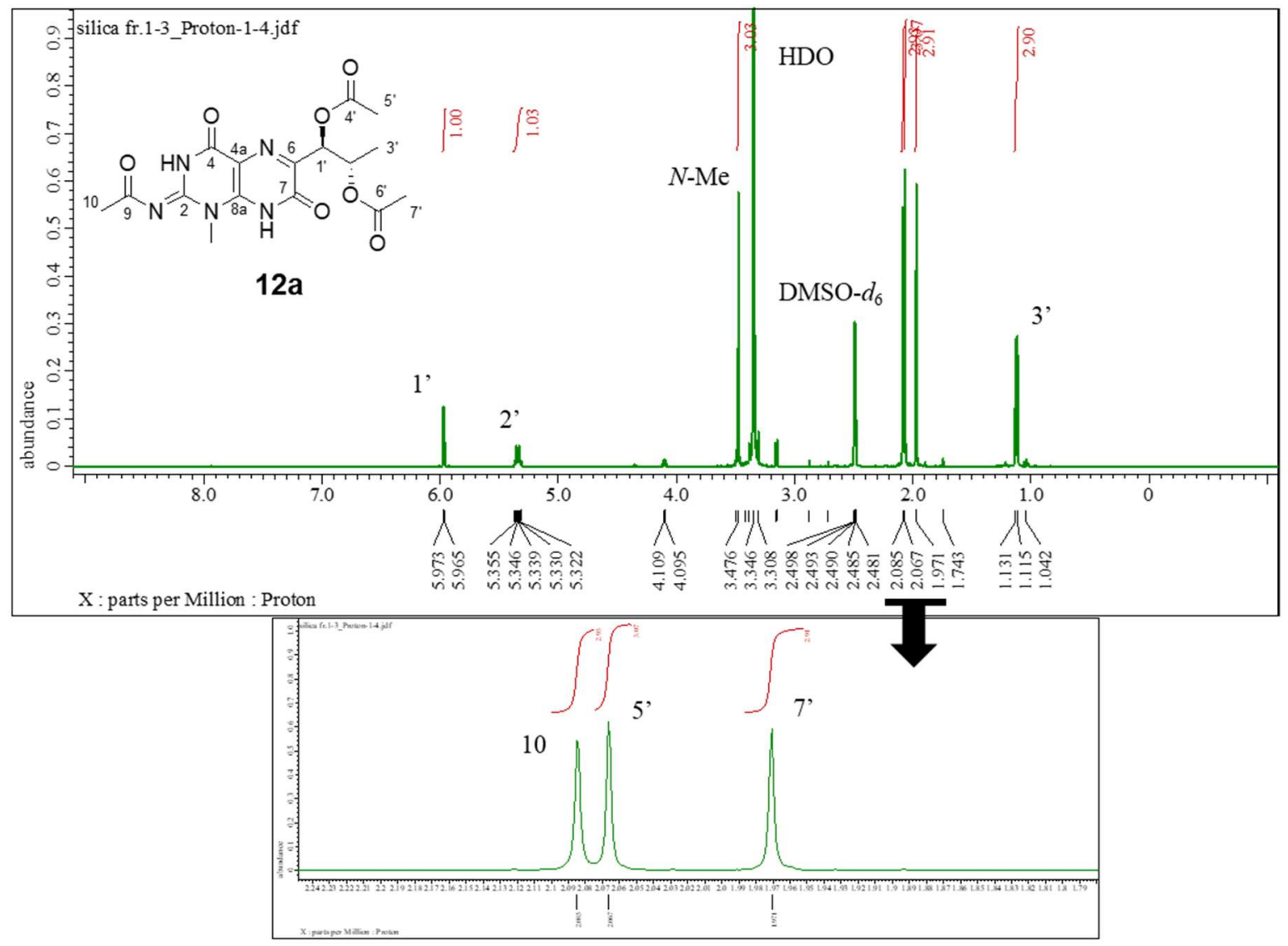

Figure S100. ${ }^{1} \mathrm{H}$ NMR spectrum of 12a in DMSO- $d_{6}(400 \mathrm{MHz})$.

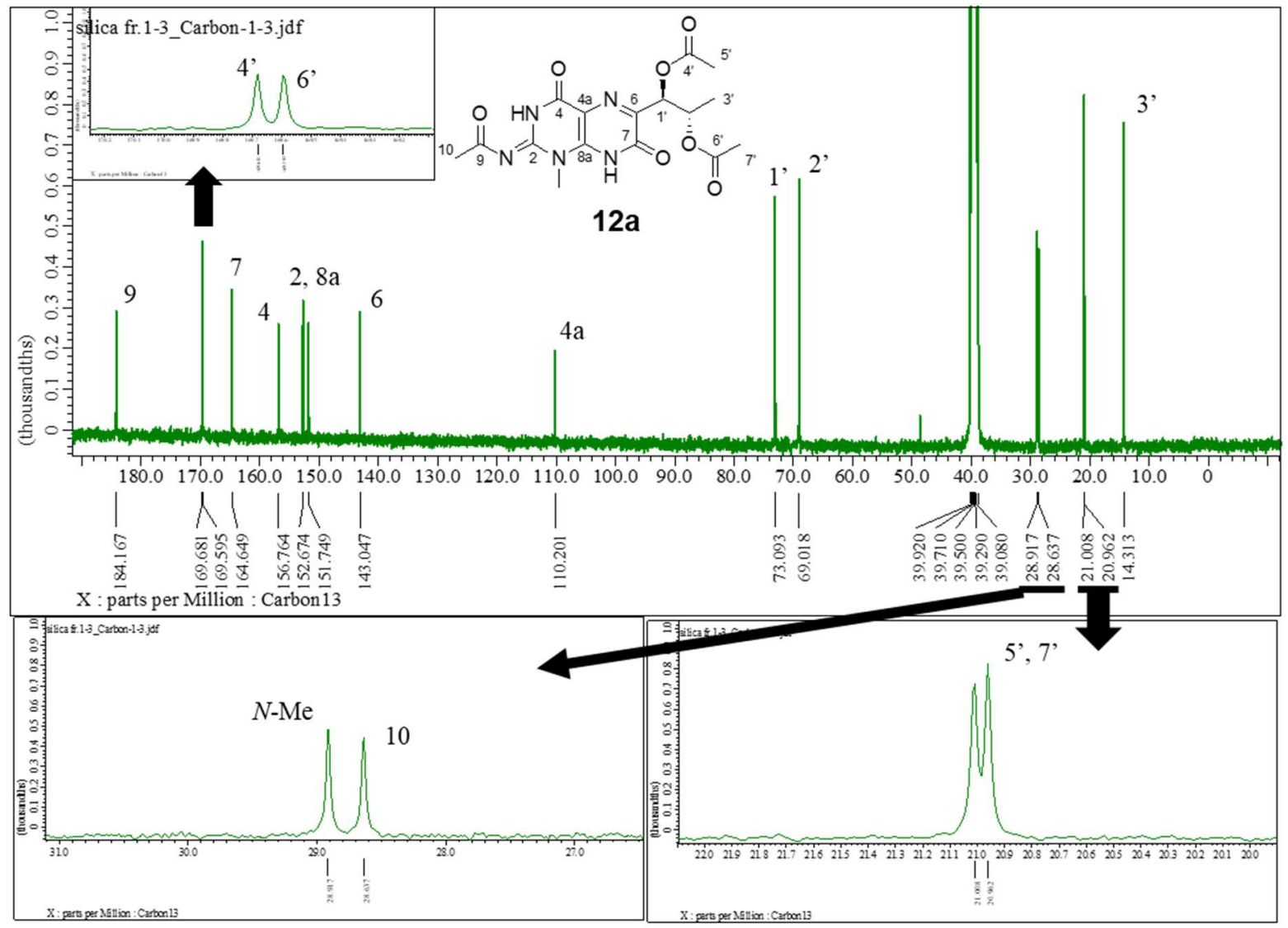

Figure S101. ${ }^{13} \mathrm{C}$ NMR spectrum of 12a in DMSO- $d_{6}(100 \mathrm{MHz})$. 


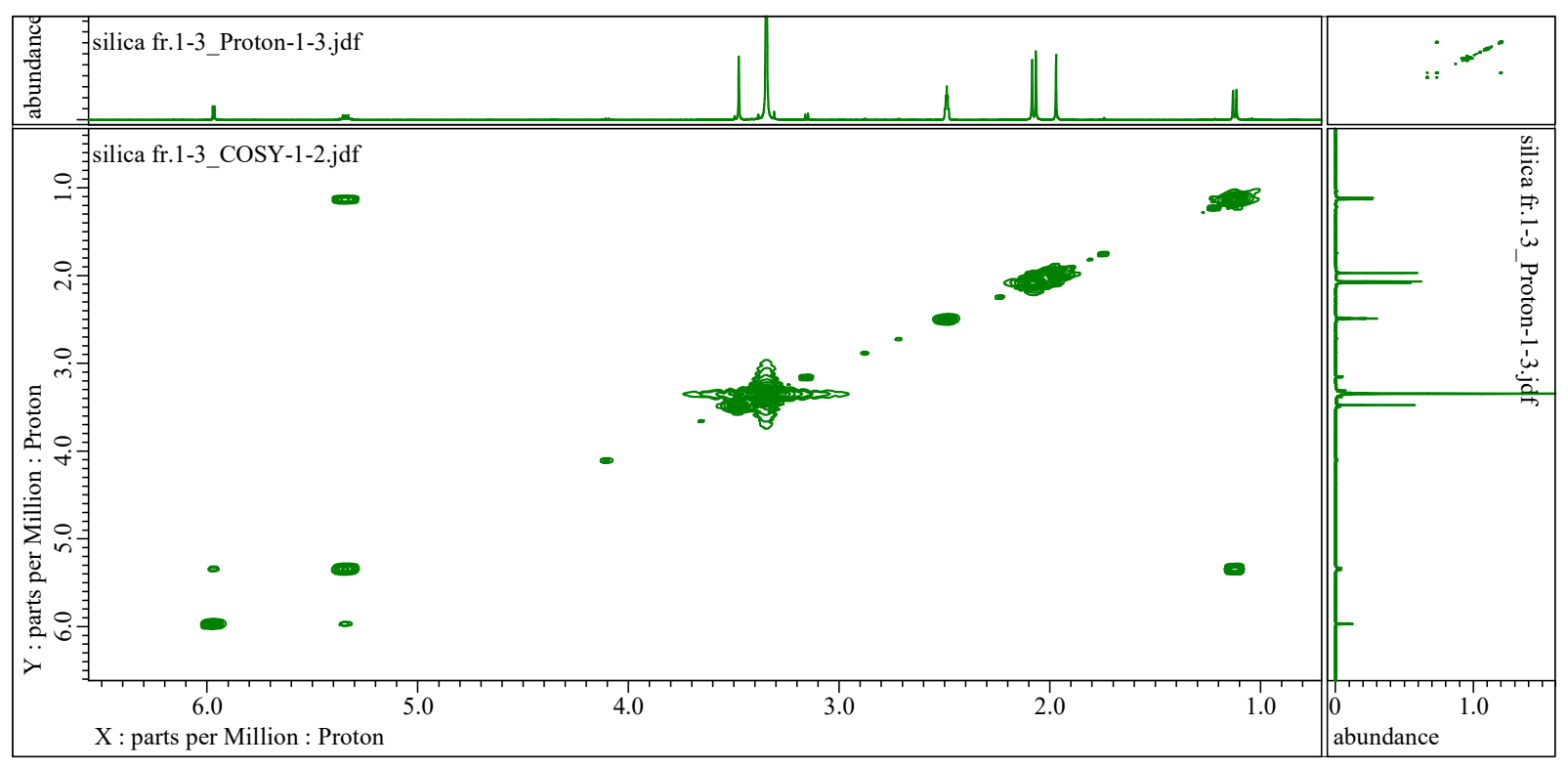

Figure S102. COSY spectrum of 12a in DMSO- $d_{6}$.

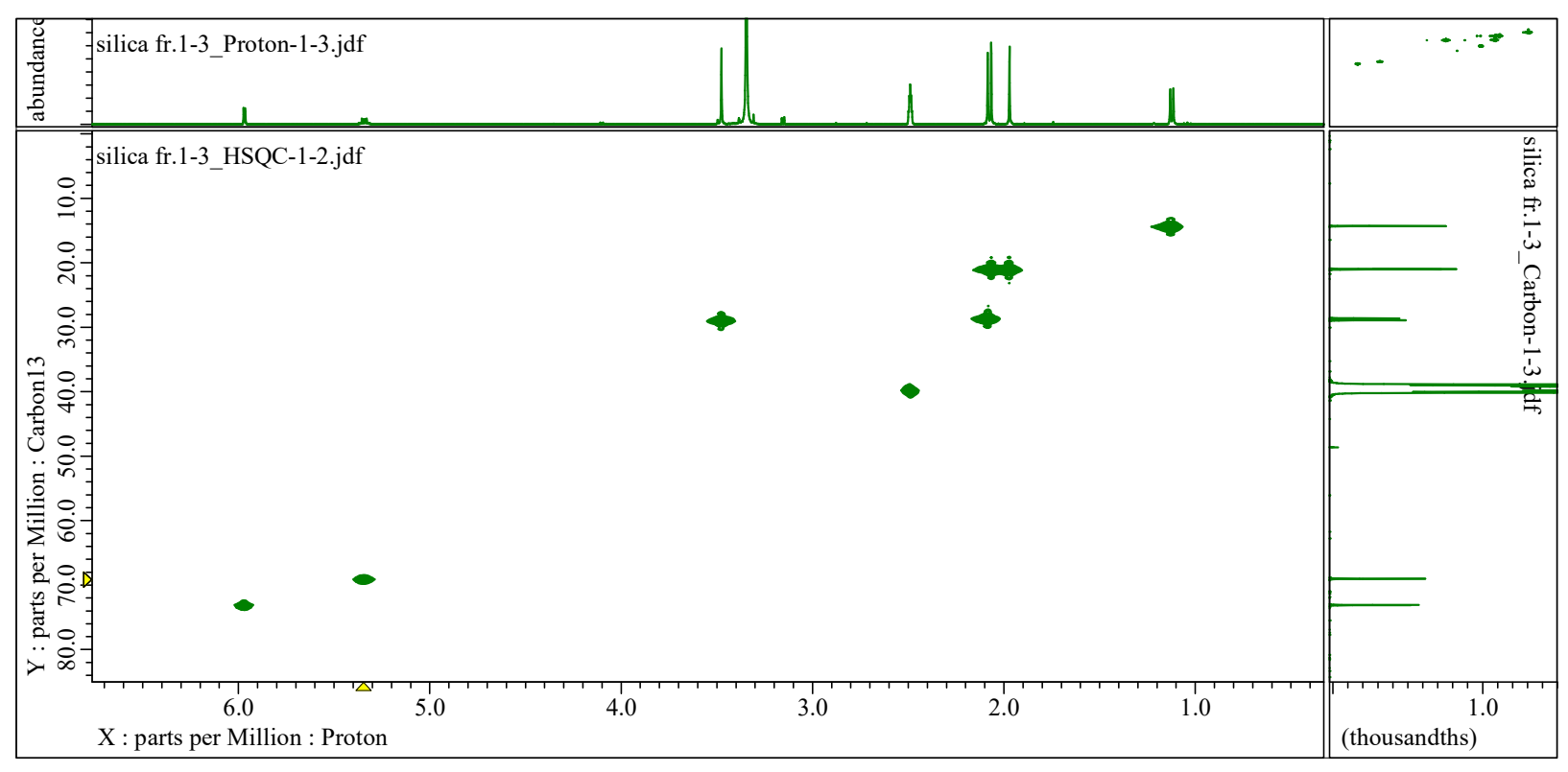

Figure S103. HSQC spectrum of 12a in DMSO- $d_{6}$. 


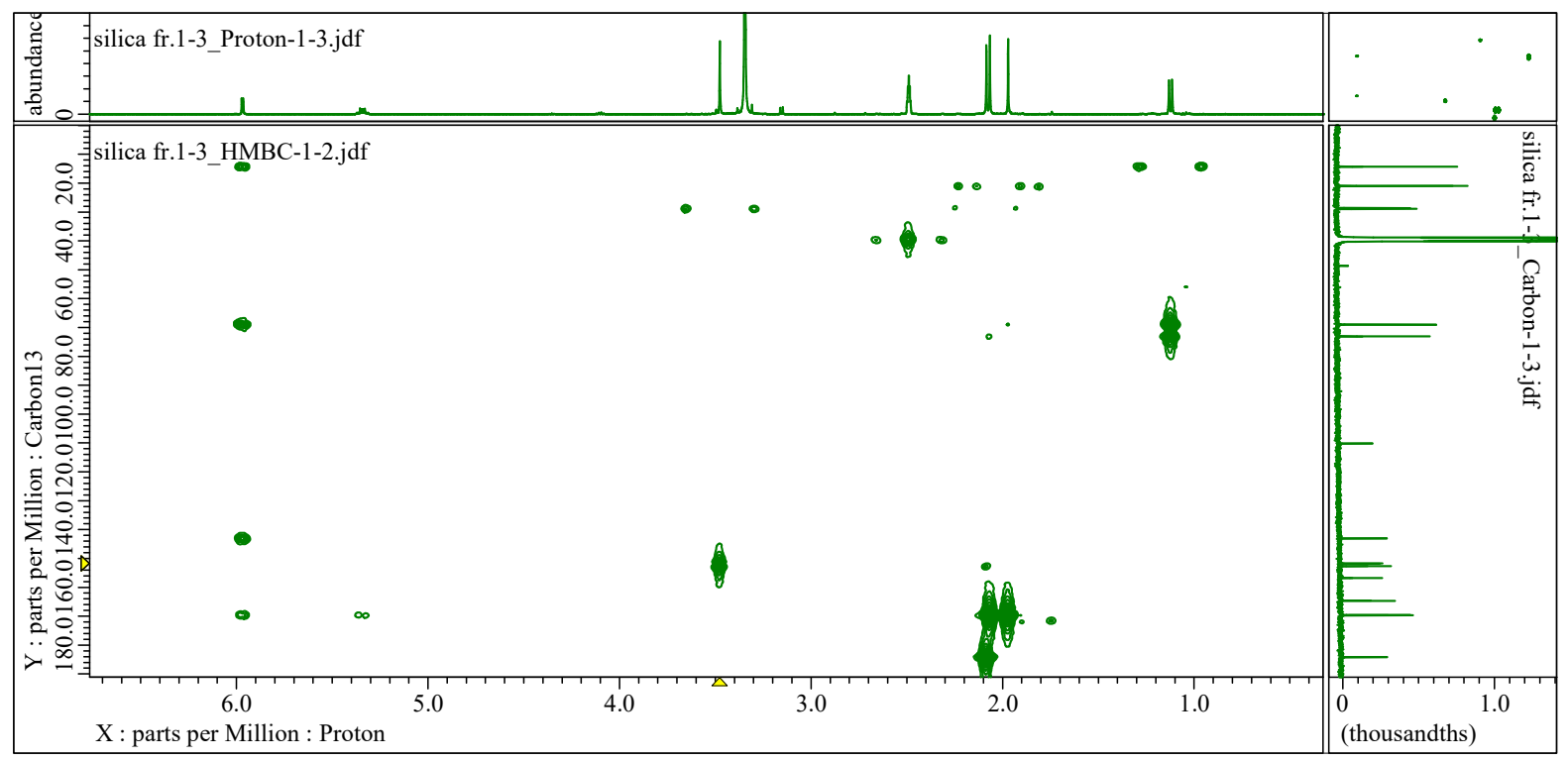

Figure S104. HMBC spectrum of 12a in DMSO- $d_{6}$.

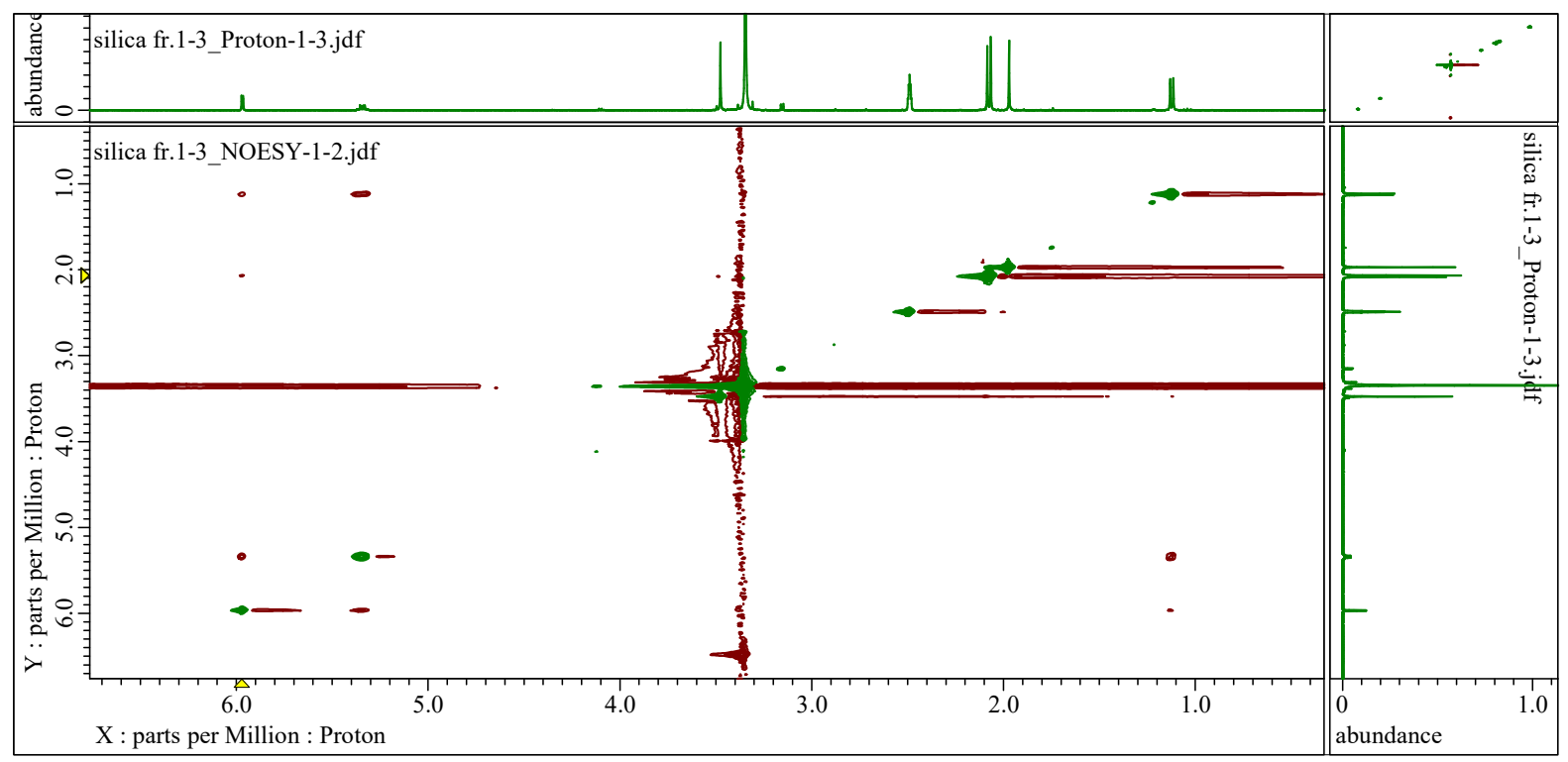

Figure S105. NOESY spectrum of 12a in DMSO- $d_{6}$. 
3.8. Physiochemical properties, spectral data and NMR assignments for 3,7-dimethylguanine (13).

3,7-dimethylguanine (13), white solid: UV $\left(\mathrm{H}_{2} \mathrm{O}\right) \lambda_{\max }(\log \varepsilon) 214$ (3.96), 235 (3.53), 268 (3.67) nm; IR (KBr) $v_{\max }$ 3414, 2920, 2850, 1693, 1402, 1131, $1075 \mathrm{~cm}^{-1} ;{ }^{1} \mathrm{H}$ NMR ( $\mathrm{D}_{2} \mathrm{O}$ with $\left.10 \mu \mathrm{L} \mathrm{CD}_{3} \mathrm{OD}, 400 \mathrm{MHz}\right)$ and ${ }^{13} \mathrm{C}$ NMR $(100$ MHz) (Table S12); HRESIMS $m / z 180.0880[\mathrm{M}+\mathrm{H}]^{+}\left(\right.$calcd for $\mathrm{C}_{7} \mathrm{H}_{9} \mathrm{~N}_{5} \mathrm{O}, m / z$ 180.0880).

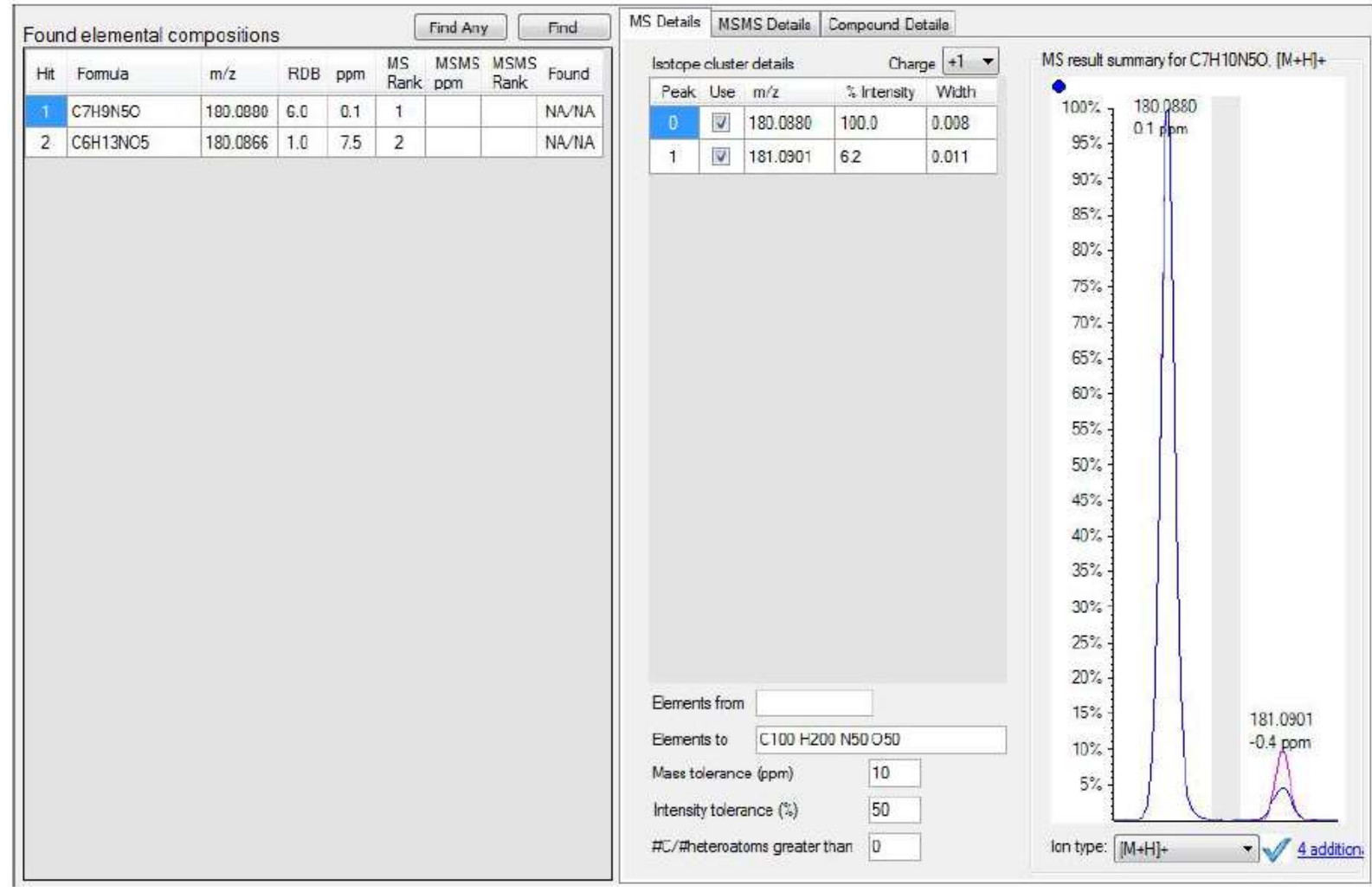

Figure S106. HRESIMS data for 3,7-dimeythylguanine (13). 


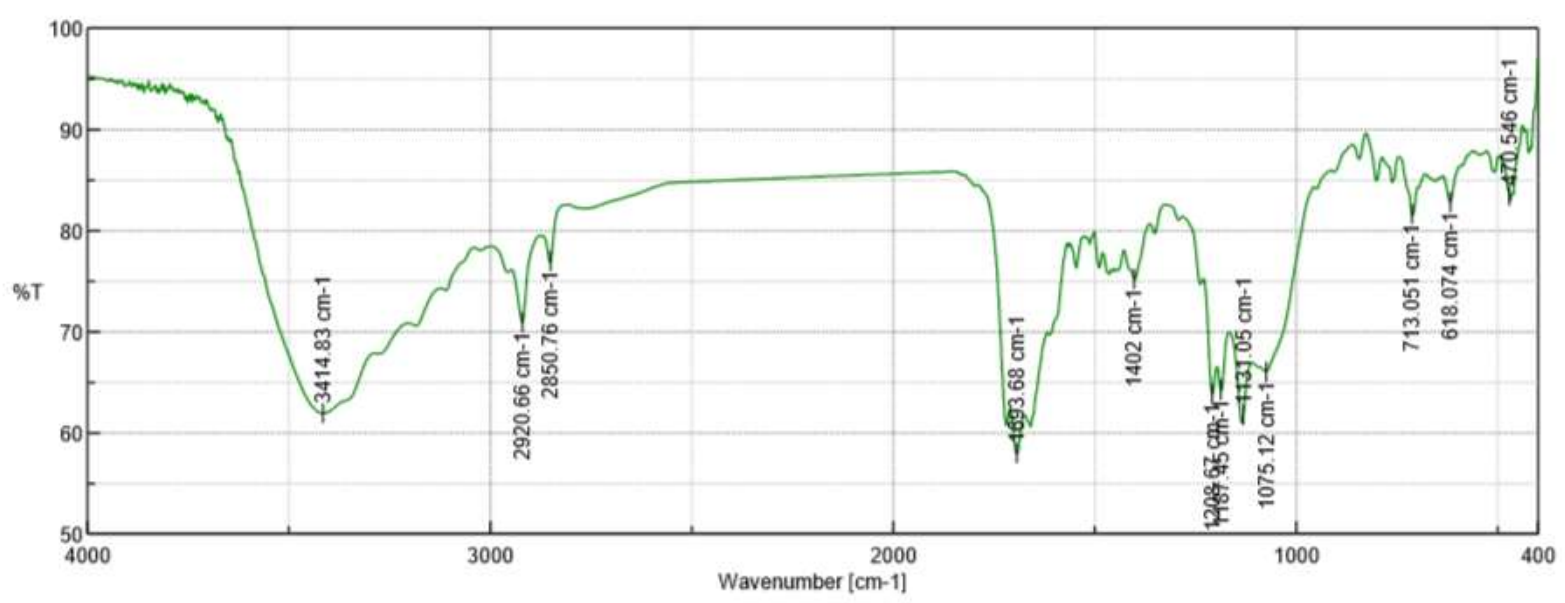

Figure S107. IR spectrum of 3,7-dimeythylguanine (13).

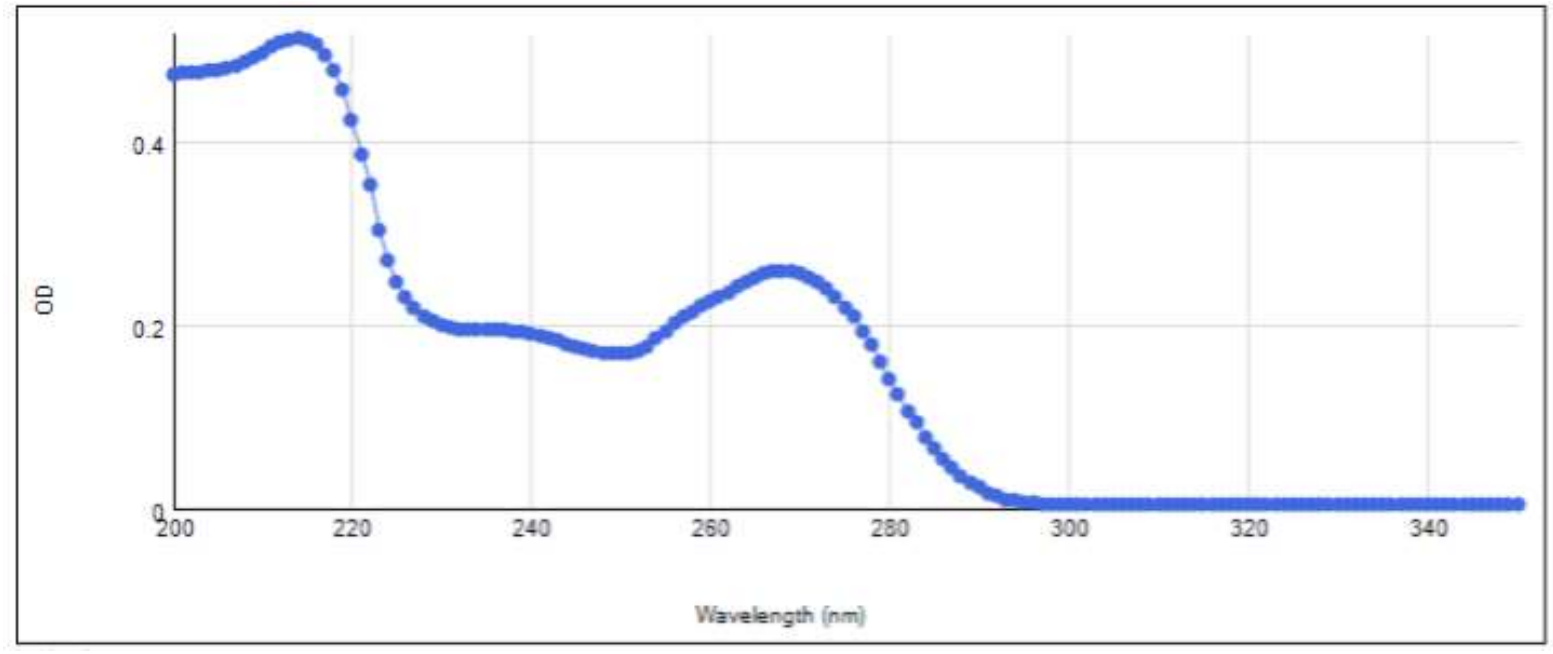

Figure S108. UV spectrum of 3,7-dimeythylguanine (13). 
Table S12. NMR data ( $\left.{ }^{1} \mathrm{H}: 400 \mathrm{MHz},{ }^{13} \mathrm{C}: 100 \mathrm{MHz}\right)$ for 3,7-dimethylguanine (13).

\begin{tabular}{cccc}
$\# \mathrm{C}$ & $\delta_{\mathrm{C}}$ & $\delta_{\mathrm{H}}$ mult. $(J$ in Hz$)$ & HMBC \\
\hline 2 & $152.5, \mathrm{C}$ & & \\
4 & $149.7, \mathrm{C}$ & & \\
5 & $110.7, \mathrm{C}$ & & \\
6 & $155.3, \mathrm{C}$ & & 4,5 \\
8 & $145.5, \mathrm{CH}$ & $8.01, \mathrm{~s}$ & 2,4 \\
$3-\mathrm{Me}$ & $32.6, \mathrm{CH}_{3}$ & $3.70, \mathrm{~s}$ & 5,8 \\
$7-\mathrm{Me}$ & $34.7, \mathrm{CH}_{3}$ & $3.97, \mathrm{~s}$ & \\
\hline \multicolumn{4}{l}{ Measured at $298 \mathrm{~K}$ in $\mathrm{D}_{2} \mathrm{O}$ with $\mathrm{CD}_{3} \mathrm{OD}$ as internal } \\
standard $\left(\delta_{\mathrm{H}} 3.30, \delta_{\mathrm{C}} 49.15 \mathrm{ppm}\right)$.
\end{tabular}

Table S 13. NMR data comparison of 3,7-dimethylguanine (13) with reported data.

\begin{tabular}{|c|c|c|c|c|c|c|}
\hline \multirow{2}{*}{$\# \mathrm{C}$} & \multicolumn{2}{|r|}{13} & \multicolumn{2}{|c|}{ 3,7-dimetylguanine $(\operatorname{Ref})^{3}$} & \multirow{2}{*}{$\begin{array}{c}\Delta \delta_{\mathrm{C}} \\
(13-\mathrm{Ref})\end{array}$} & \multirow{2}{*}{$\begin{array}{c}\Delta \delta_{\mathrm{H}} \\
(13-\mathrm{Ref})\end{array}$} \\
\hline & $\delta_{\mathrm{C}}$ & $\delta_{\mathrm{H}}$ mult. $(J$ in $\mathrm{Hz})$ & $\delta_{\mathrm{C}}$ & $\delta_{\mathrm{H}}$ mult. $(J$ in $\mathrm{Hz})$ & & \\
\hline 2 & $152.5, \mathrm{C}$ & & $152.4, \mathrm{C}$ & & 0.1 & \\
\hline 4 & 149.7, C & & $149.4, \mathrm{C}$ & & 0.3 & \\
\hline 5 & 110.7, C & & $110.5, \mathrm{C}$ & & 0.2 & \\
\hline 6 & 155.3, C & & 154.6, C & & 0.7 & \\
\hline 8 & $145.5, \mathrm{CH}$ & $8.01, \mathrm{~s}$ & $145.3, \mathrm{CH}$ & $7.85, \mathrm{~s}$ & 0.2 & 0.16 \\
\hline $3-\mathrm{Me}$ & $32.6, \mathrm{CH}_{3}$ & $3.70, \mathrm{~s}$ & $32.4, \mathrm{CH}_{3}$ & $3.53, \mathrm{~s}$ & 0.2 & 0.17 \\
\hline 7-Me & $34.7, \mathrm{CH}_{3}$ & $3.97, \mathrm{~s}$ & $34.5, \mathrm{CH}_{3}$ & $3.80, \mathrm{~s}$ & 0.2 & 0.17 \\
\hline \multicolumn{3}{|c|}{ Measured in $\mathrm{D}_{2} \mathrm{O}$ with $\mathrm{CD}_{3} \mathrm{OD}$. } & \multicolumn{3}{|c|}{ Measured in $\mathrm{D}_{2} \mathrm{O}$ with $\mathrm{CD}_{3} \mathrm{OD}$. } & \\
\hline
\end{tabular}




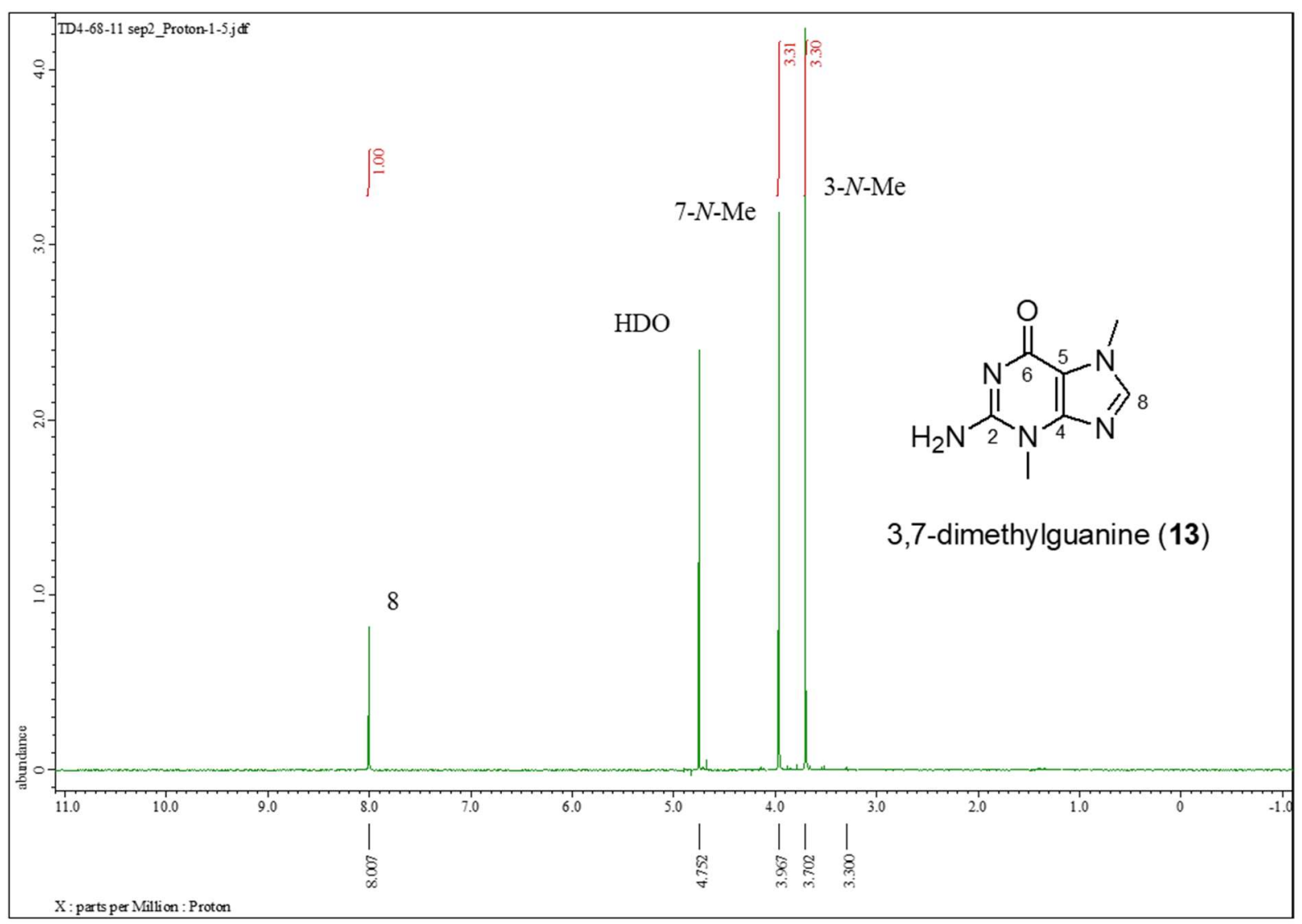

Figure S109. ${ }^{1} \mathrm{H}$ NMR spectrum of 3,7-dimethylguanine (13) in $\mathrm{D}_{2} \mathrm{O}$ with $10 \mu \mathrm{L} \mathrm{CD} \mathrm{CD}_{3} \mathrm{OD}(400 \mathrm{MHz})$.

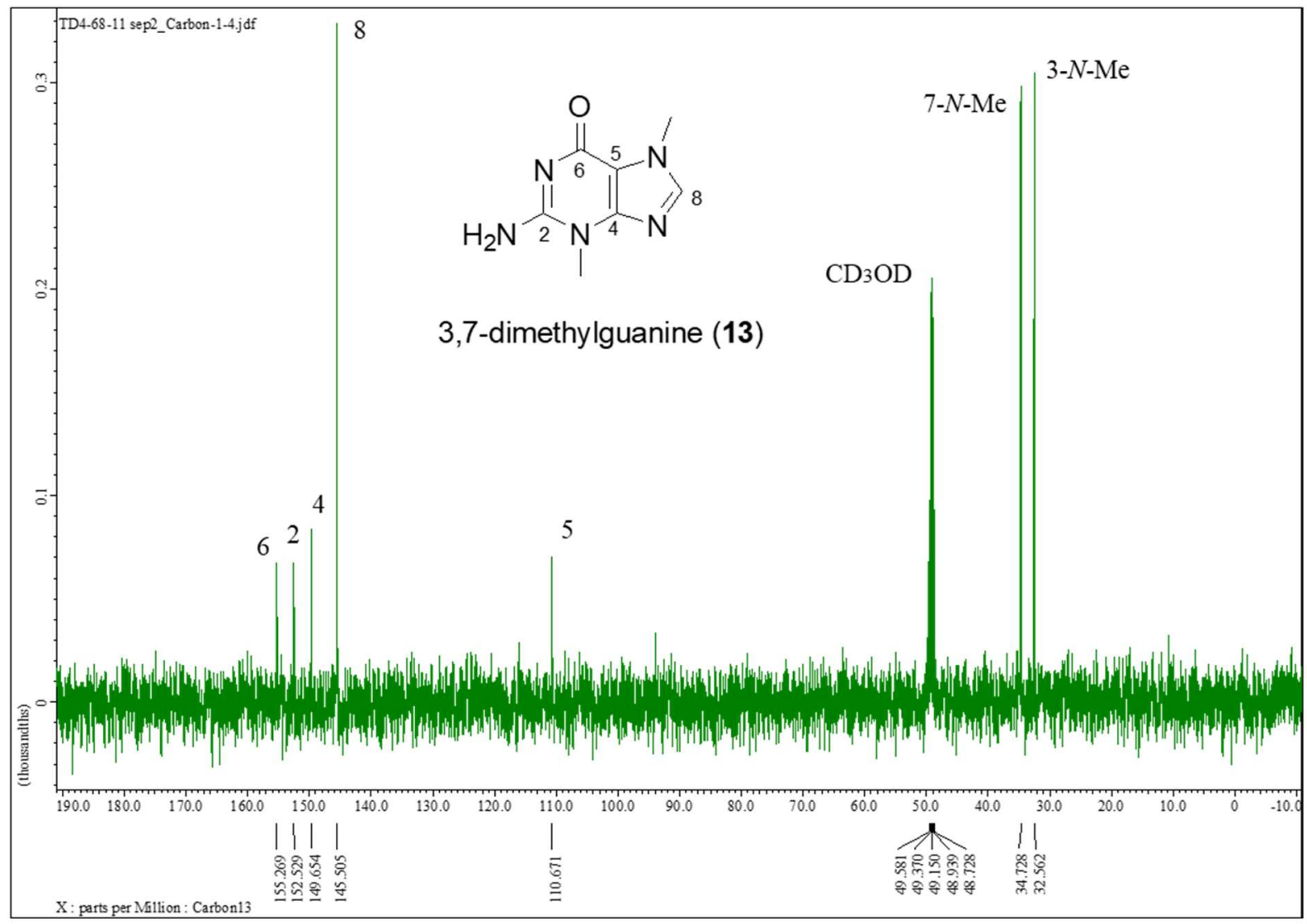

Figure S110. ${ }^{13} \mathrm{C}$ NMR spectrum of 3,7-dimethylguanine (13) in $\mathrm{D}_{2} \mathrm{O}$ with $10 \mu \mathrm{L} \mathrm{CD} \mathrm{CD}_{3} \mathrm{OD}(100 \mathrm{MHz})$. 


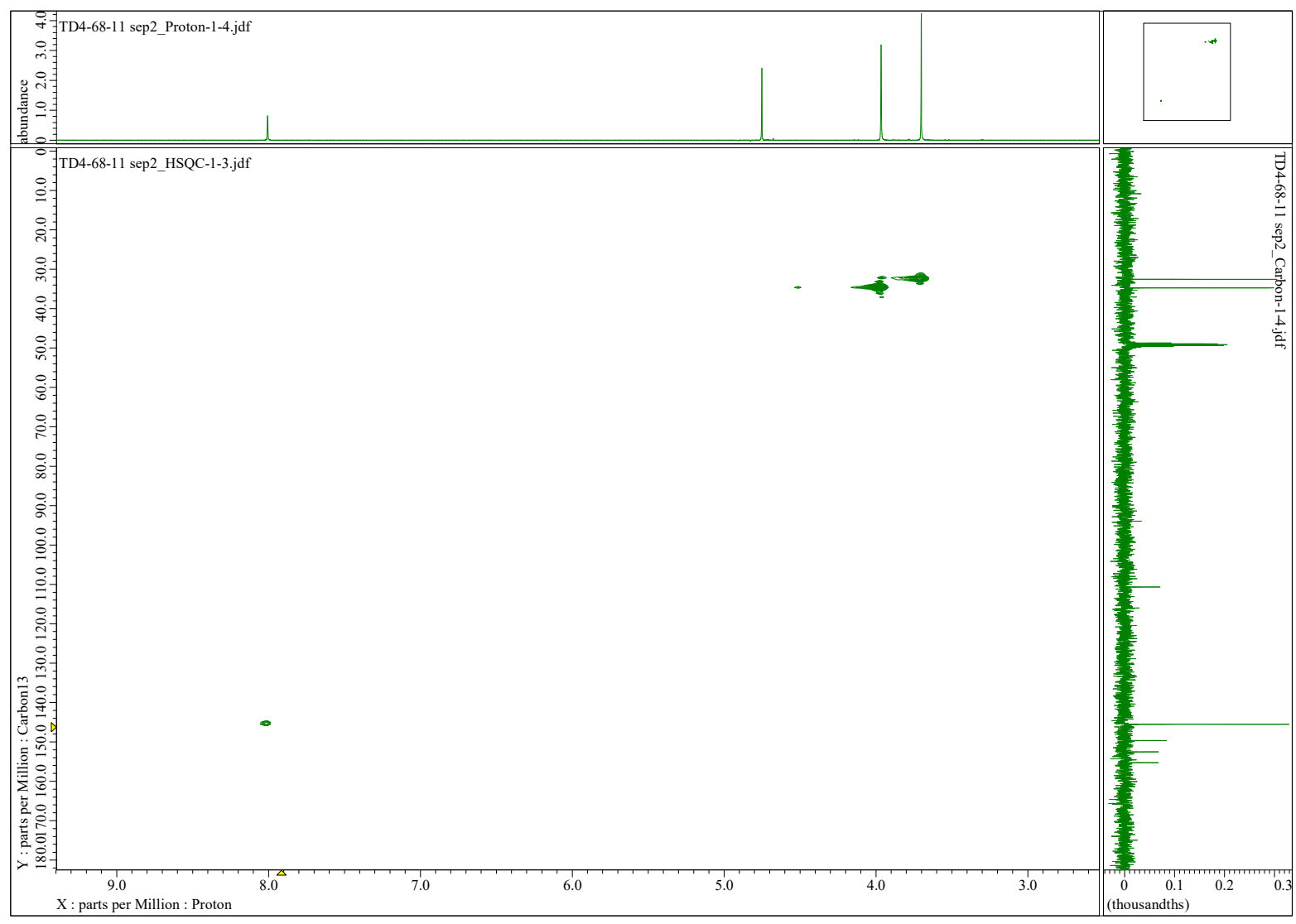

Figure S111. HSQC spectrum of 3,7-dimethylguanine (13) in $\mathrm{D}_{2} \mathrm{O}$ with $10 \mu \mathrm{L} \mathrm{CD}_{3} \mathrm{OD}$.

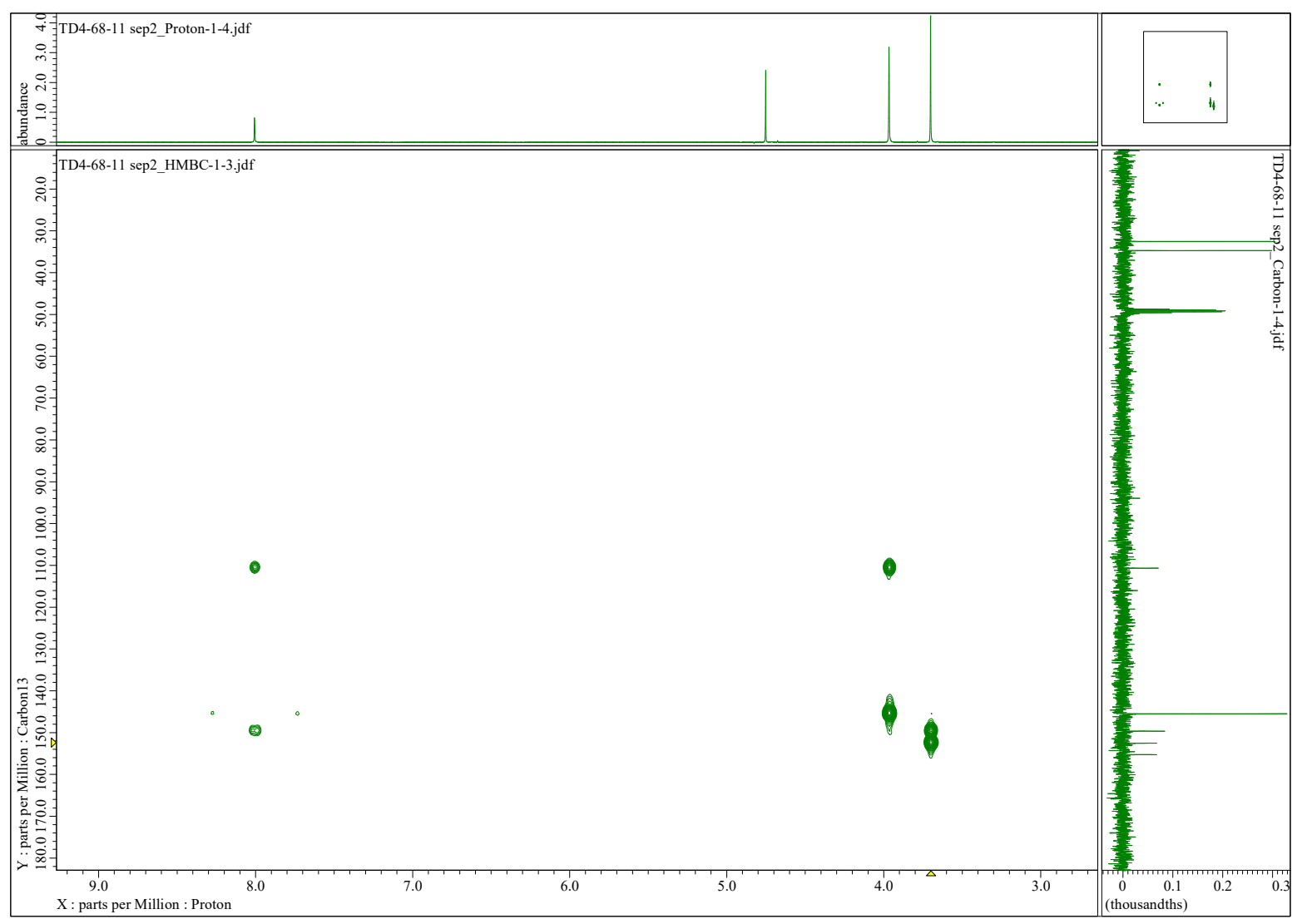

Figure S112. HMBC spectrum of 3,7-dimethylguanine (13) in $\mathrm{D}_{2} \mathrm{O}$ with $10 \mu \mathrm{L} \mathrm{CD}_{3} \mathrm{OD}$. 
3.9. Spectral data and NMR assignments for ireneguanine (14).

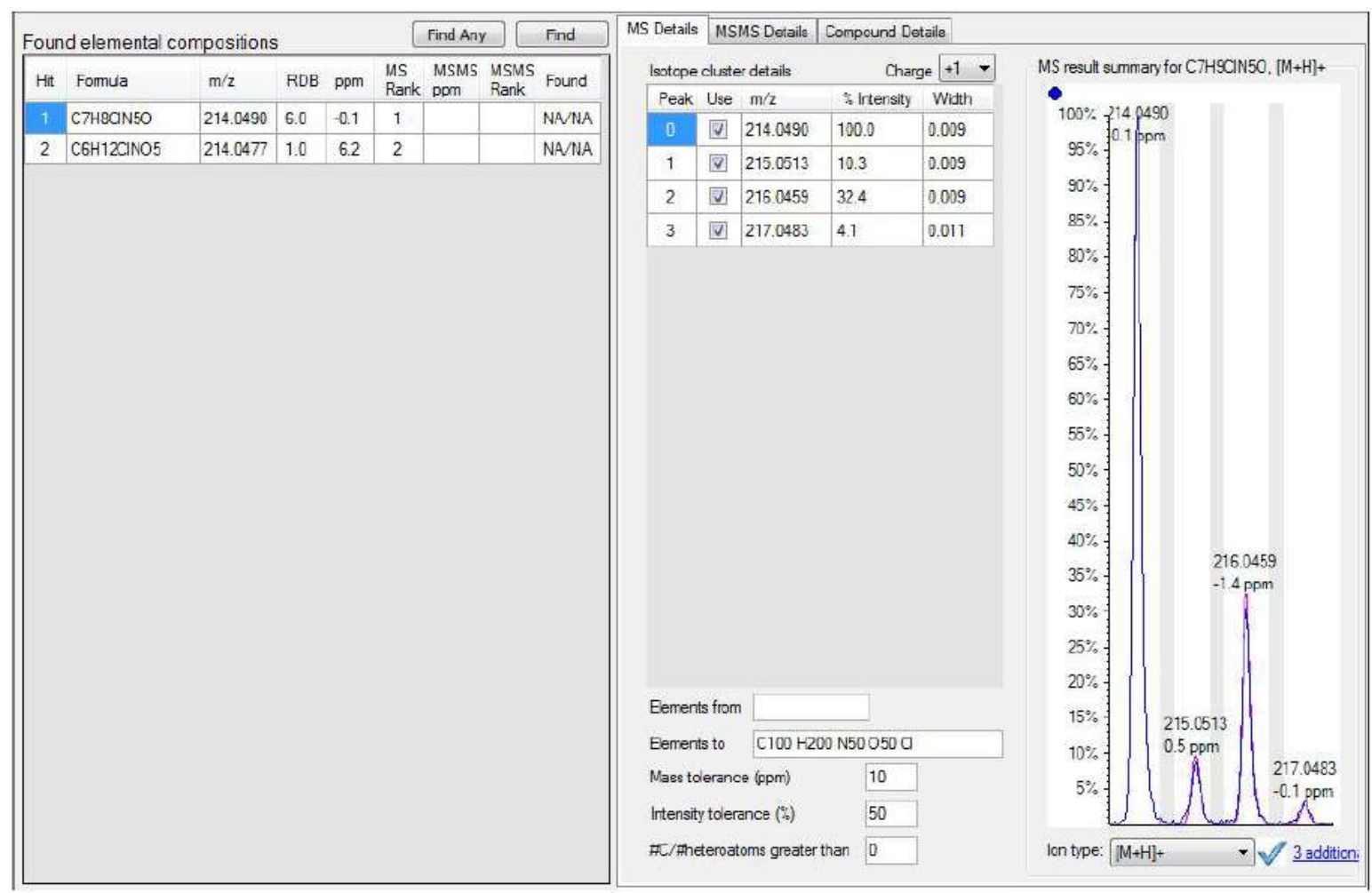

Figure S113. HRESIMS data for ireneguanine (14).

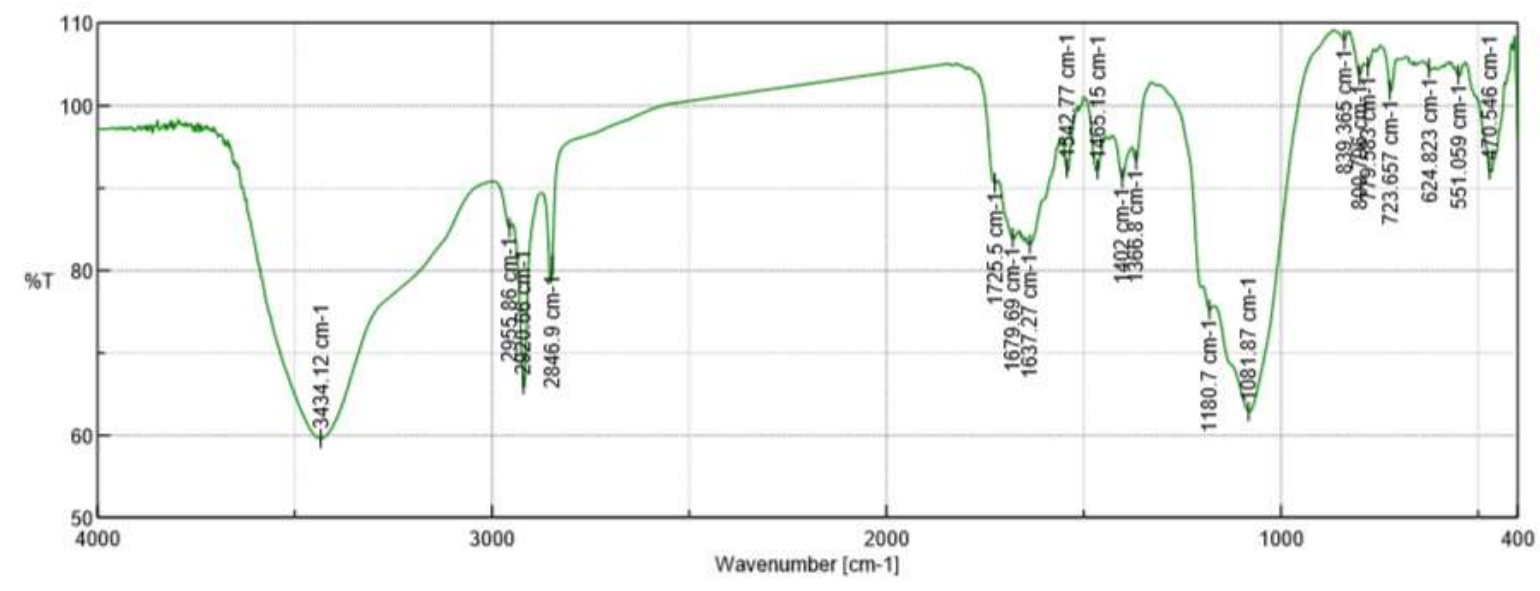

Figure S114. IR spectrum of ireneguanine (14). 


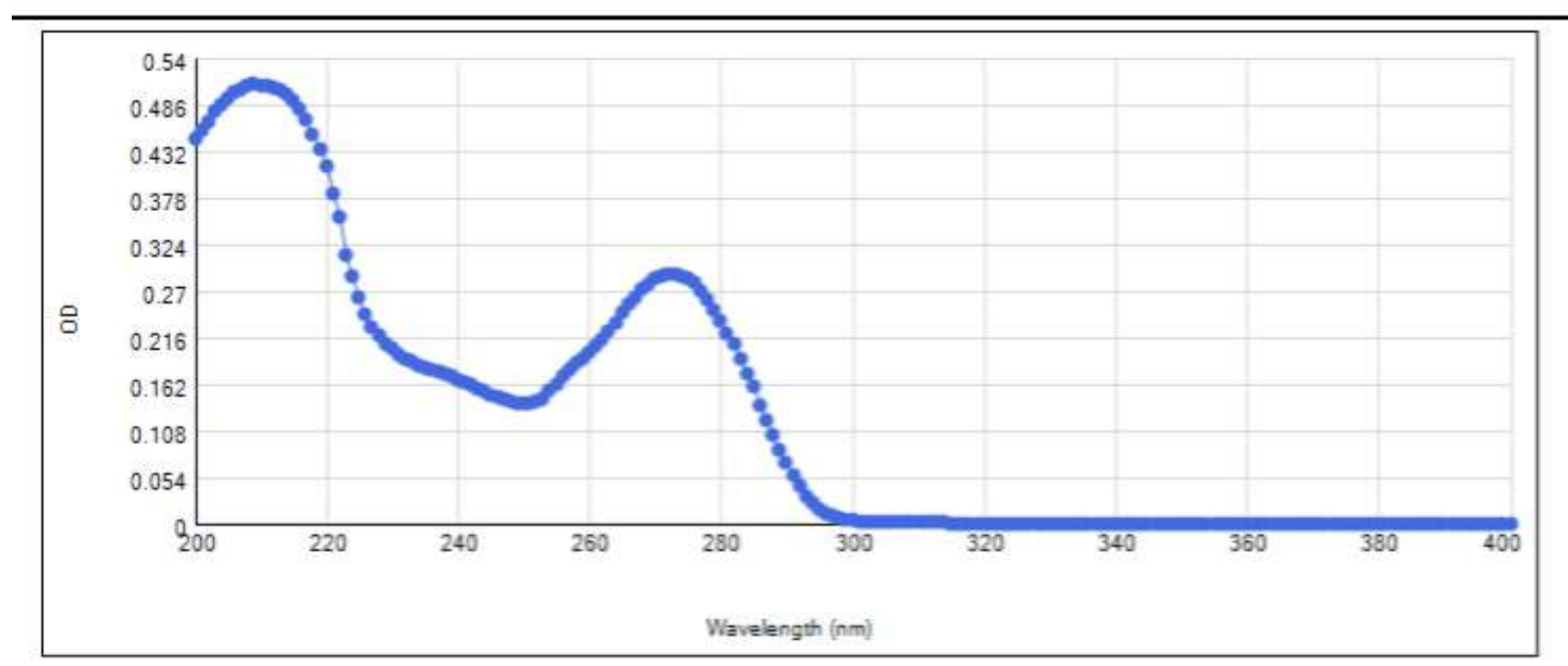

Figure S115. UV spectrum of ireneguanine (14).

Table S14. NMR data $\left({ }^{1} \mathrm{H}: 400 \mathrm{MHz},{ }^{13} \mathrm{C}: 100 \mathrm{MHz}\right)$ for ireneguanine (14).

\begin{tabular}{cccc}
$\# \mathrm{C}$ & $\delta_{\mathrm{C}}$ & $\delta_{\mathrm{H}}$ mult. $(J$ in $\mathrm{Hz})$ & HMBC \\
\hline 2 & $152.7, \mathrm{C}$ & & \\
4 & $148.1, \mathrm{C}$ & & \\
5 & $111.6, \mathrm{C}$ & & \\
6 & $155.0, \mathrm{C}$ & & \\
8 & $142.7, \mathrm{C}$ & & 2,4 \\
$3-\mathrm{Me}$ & $32.6, \mathrm{CH}_{3}$ & $3.66, \mathrm{~s}$ & 5,8 \\
$7-\mathrm{Me}$ & $33.9, \mathrm{CH}_{3}$ & $3.92, \mathrm{~s}$ & 5 \\
\hline
\end{tabular}

Measured at $303 \mathrm{~K}$ in $\mathrm{D}_{2} \mathrm{O}$ with $10 \mu \mathrm{L} \mathrm{CD}_{3} \mathrm{OD}$ as internal standard $\left(\delta_{\mathrm{H}} 3.30, \delta_{\mathrm{C}} 49.15 \mathrm{ppm}\right)$.

Table S15. NMR data comparison of ireneguanine (13) with 3,7-dimethylguanine (14).

\begin{tabular}{|c|c|c|c|c|c|c|}
\hline & & 14 & & 13 & $\Delta \delta_{\mathrm{C}}$ & $\Delta \delta_{\mathrm{H}}(14-13)$ \\
\hline$\# \mathrm{C}$ & $\delta_{\mathrm{C}}$ & $\delta_{\mathrm{H}}$ mult. $(J$ in $\mathrm{Hz})$ & $\delta_{\mathrm{C}}$ & $\delta_{\mathrm{H}}$ mult. $(J$ in $\mathrm{Hz})$ & & \\
\hline 2 & $152.7, \mathrm{C}$ & & $152.5, \mathrm{C}$ & & 0.2 & \\
\hline 4 & $148.1, \mathrm{C}$ & & 149.7, C & & -1.6 & \\
\hline 5 & 111.6, C & & 110.7, C & & 0.9 & \\
\hline 6 & 155.0, C & & 155.3, C & & -0.3 & \\
\hline 8 & $142.7, \mathrm{C}$ & & $145.5, \mathrm{CH}$ & $8.01, \mathrm{~s}$ & -2.8 & \\
\hline 3-Me & $32.6, \mathrm{CH} 3$ & $3.66, \mathrm{~s}$ & $32.6, \mathrm{CH} 3$ & $3.70, \mathrm{~s}$ & 0 & -0.04 \\
\hline 7-Me & $33.9, \mathrm{CH} 3$ & $3.92, \mathrm{~s}$ & $34.7, \mathrm{CH} 3$ & $3.97, \mathrm{~s}$ & -0.8 & -0.05 \\
\hline
\end{tabular}




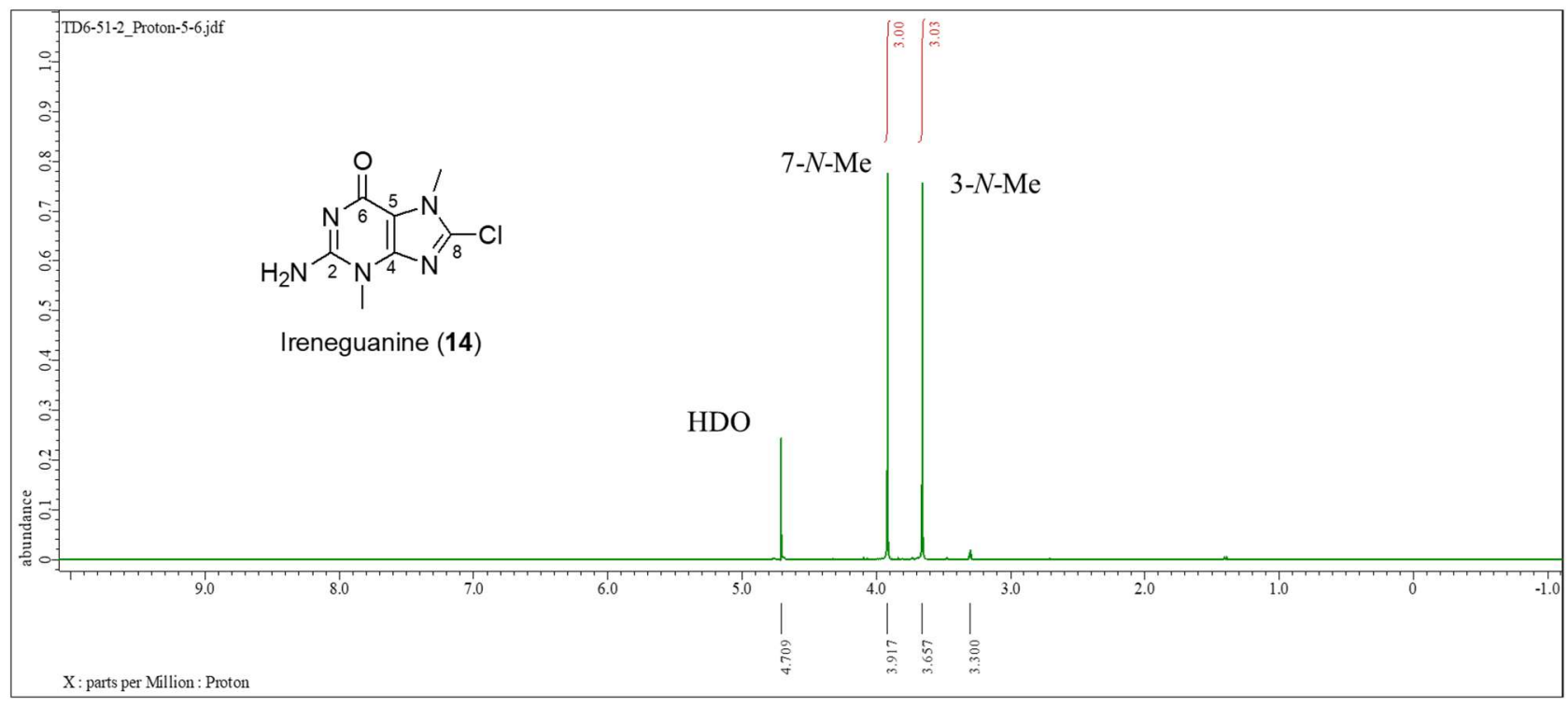

Figure S116. ${ }^{1} \mathrm{H}$ NMR spectrum of ireneguanine (14) in $\mathrm{D}_{2} \mathrm{O}$ with $10 \mu \mathrm{L} \mathrm{CD}_{3} \mathrm{OD}(400 \mathrm{MHz})$.

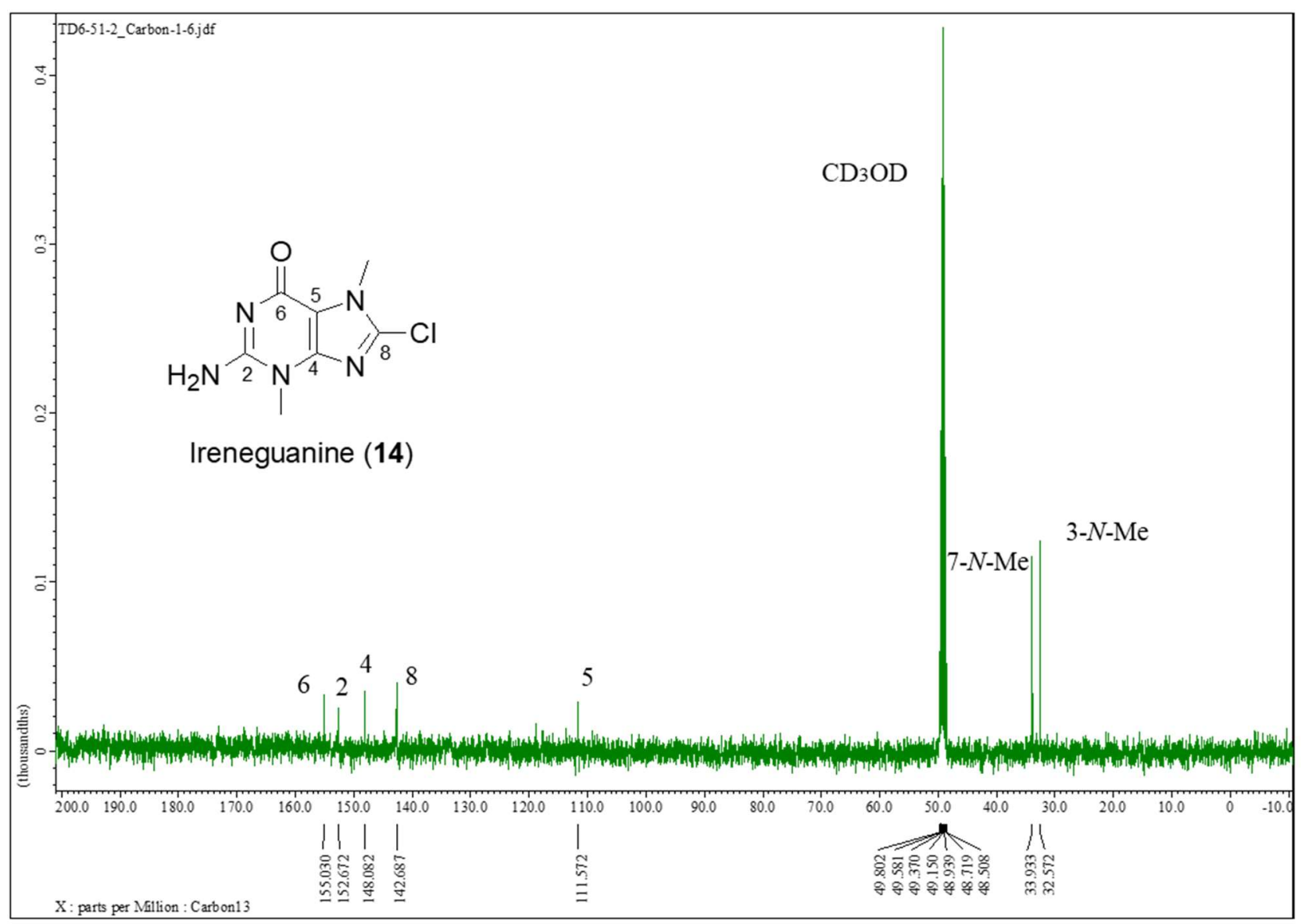

Figure S117. ${ }^{13} \mathrm{C}$ NMR spectrum of ireneguanine (14) in $\mathrm{D}_{2} \mathrm{O}$ with $10 \mu \mathrm{LCD}_{3} \mathrm{OD}(100 \mathrm{MHz})$. 


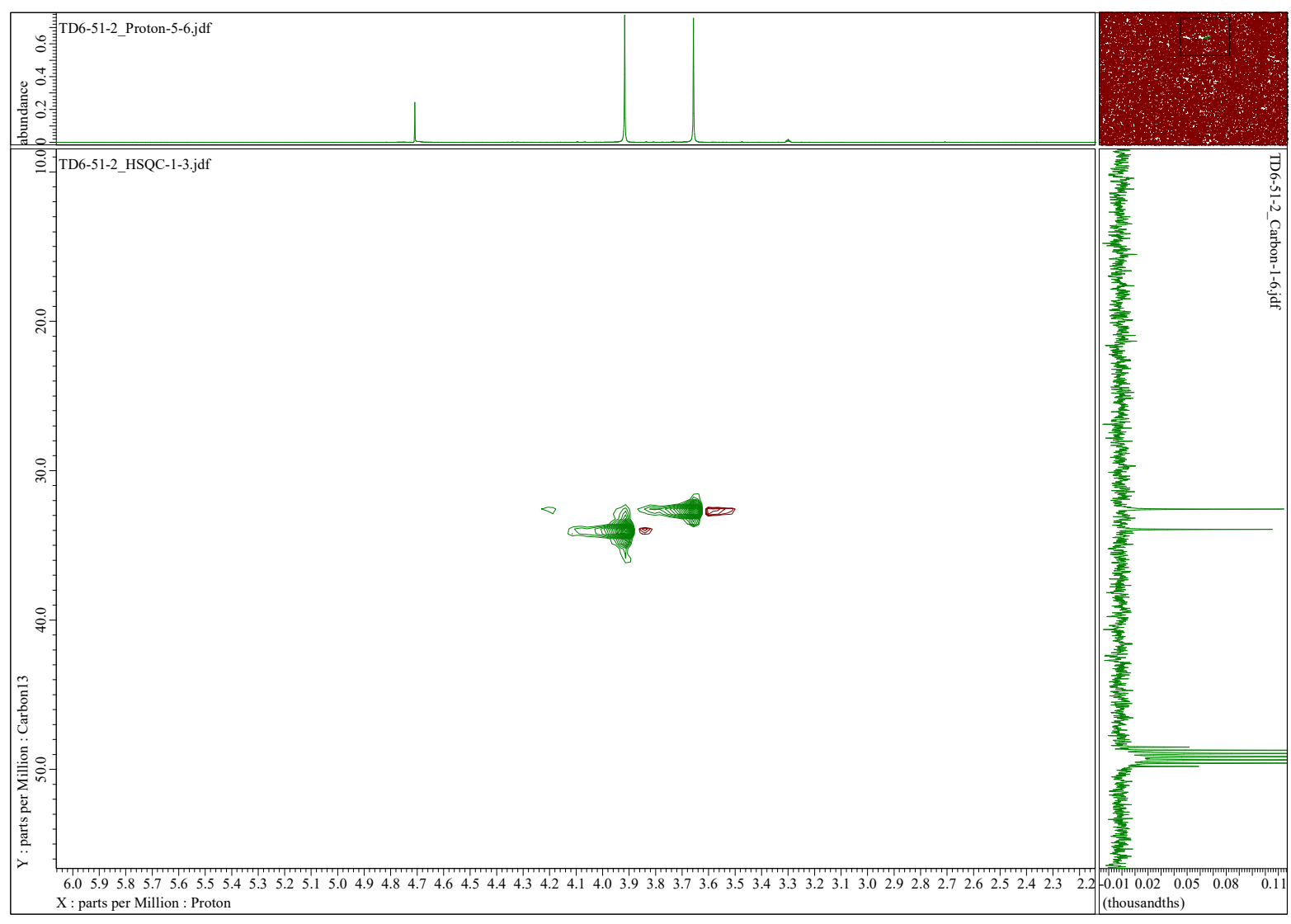

Figure S118. HSQC spectrum of ireneguanine (14) in $\mathrm{D}_{2} \mathrm{O}$ with $10 \mu \mathrm{LCD}_{3} \mathrm{OD}$.

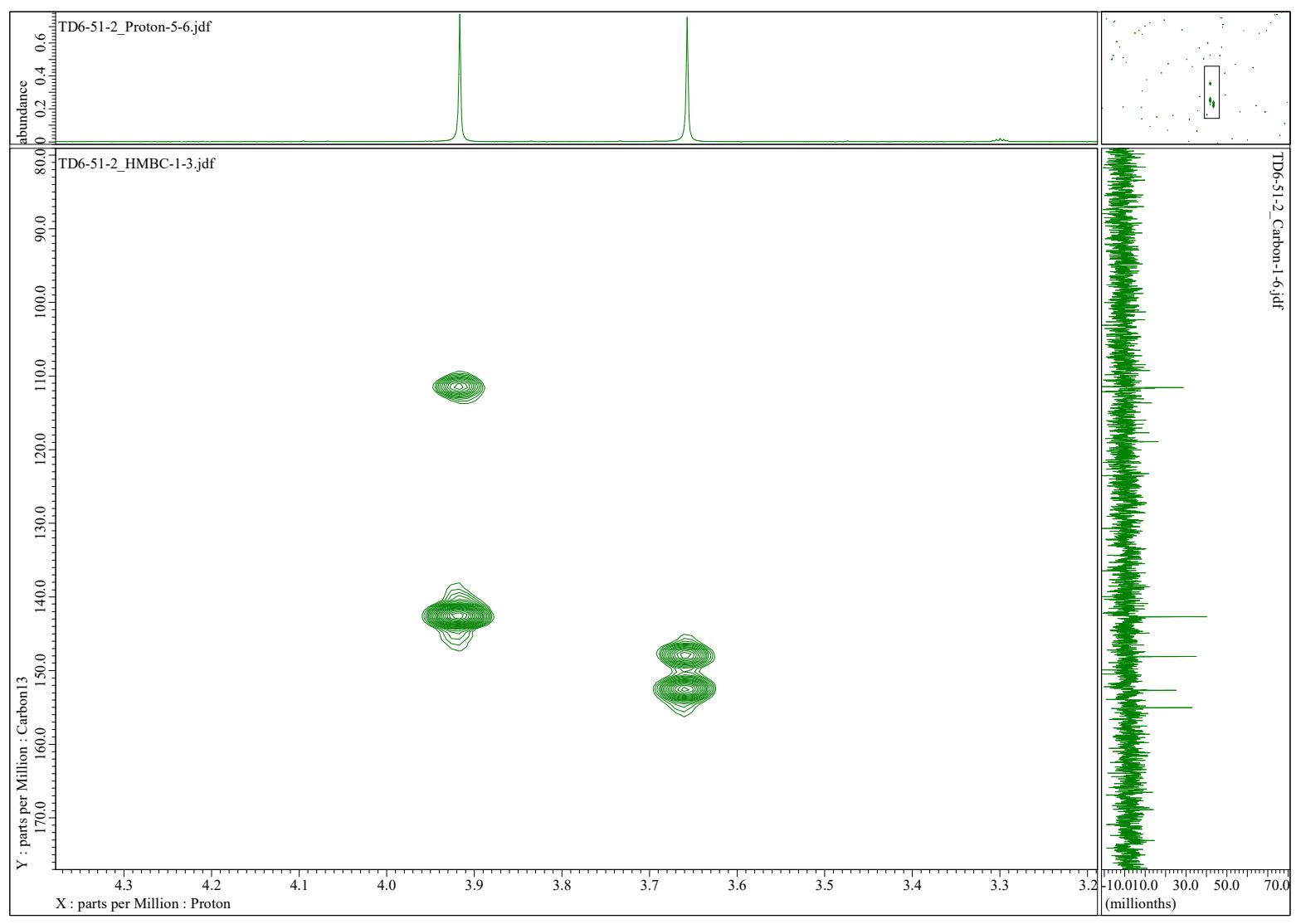

Figure S119. HMBC spectrum of ireneguanine (14) in $\mathrm{D}_{2} \mathrm{O}$ with $10 \mu \mathrm{LCD}_{3} \mathrm{OD}$. 
3.10. Spectral data and NMR assignments for irenecytidine (15).

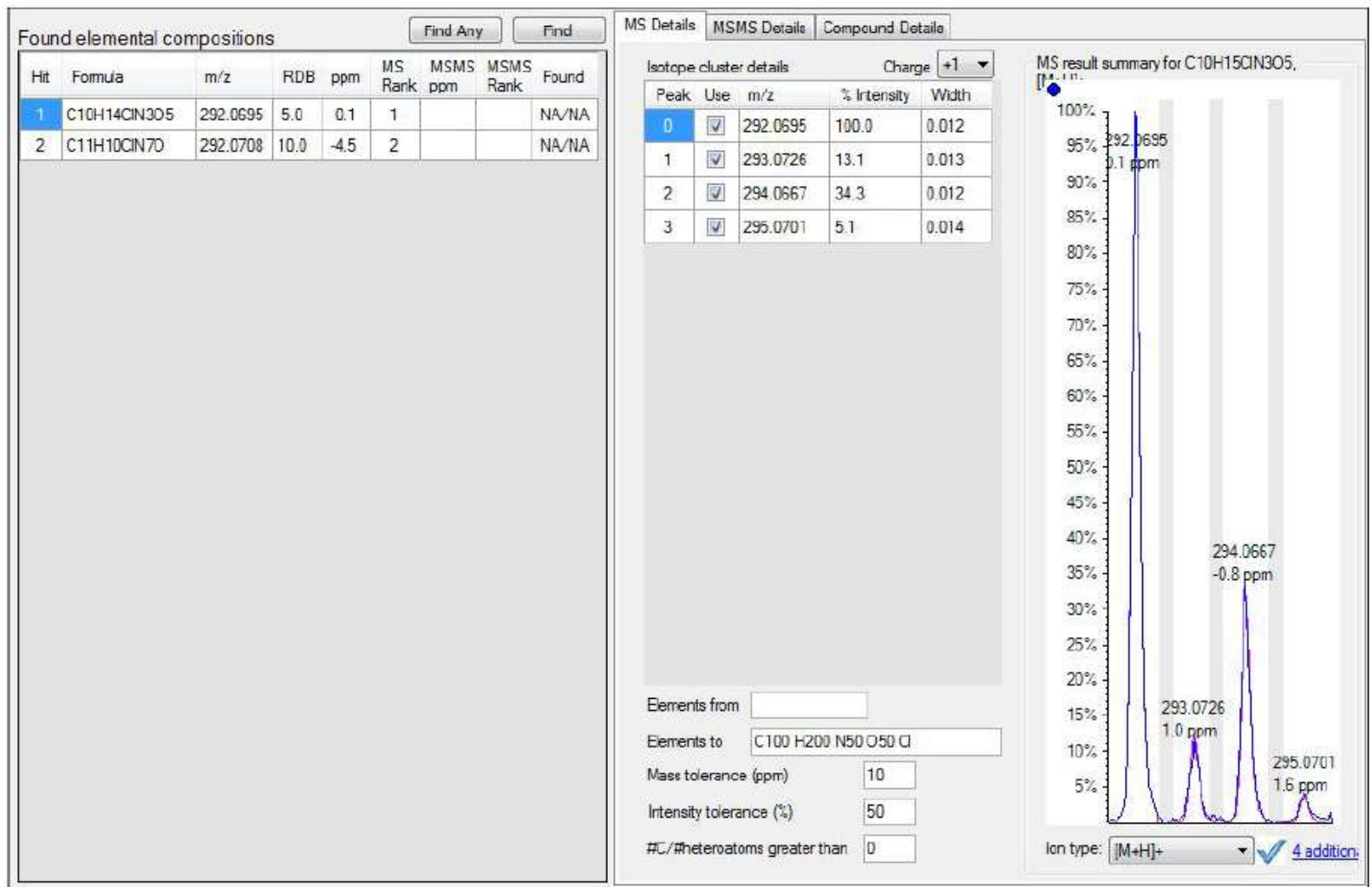

Figure S120. HRESIMS data for irenecytidine (15).

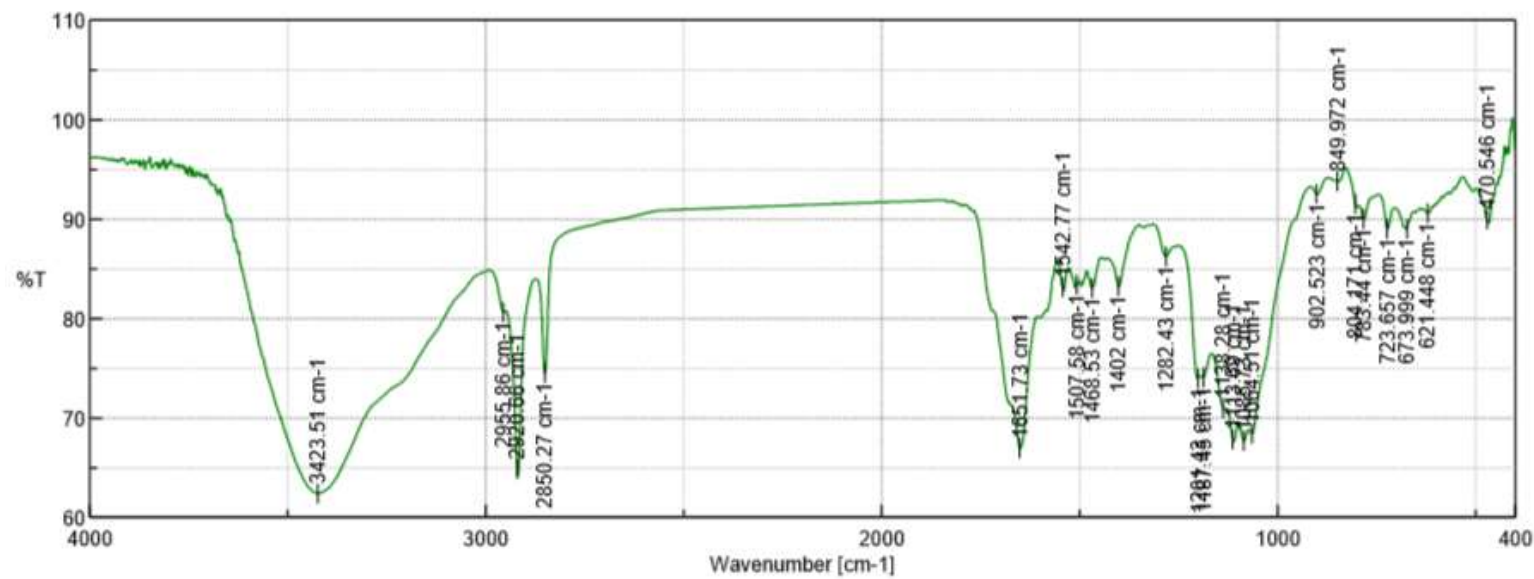

Figure S121. IR spectrum of irenecytidine (15). 


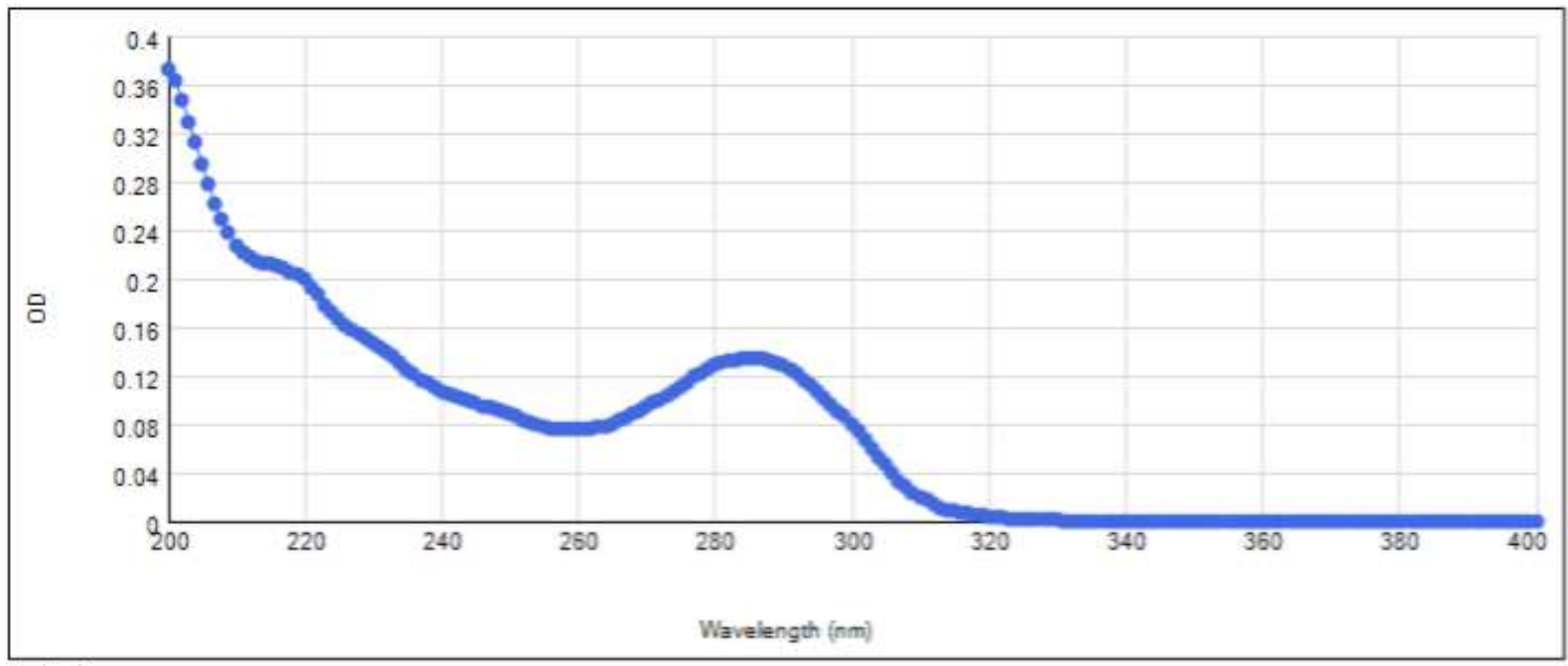

Figure S122. UV spectrum of irenecytidine (15).
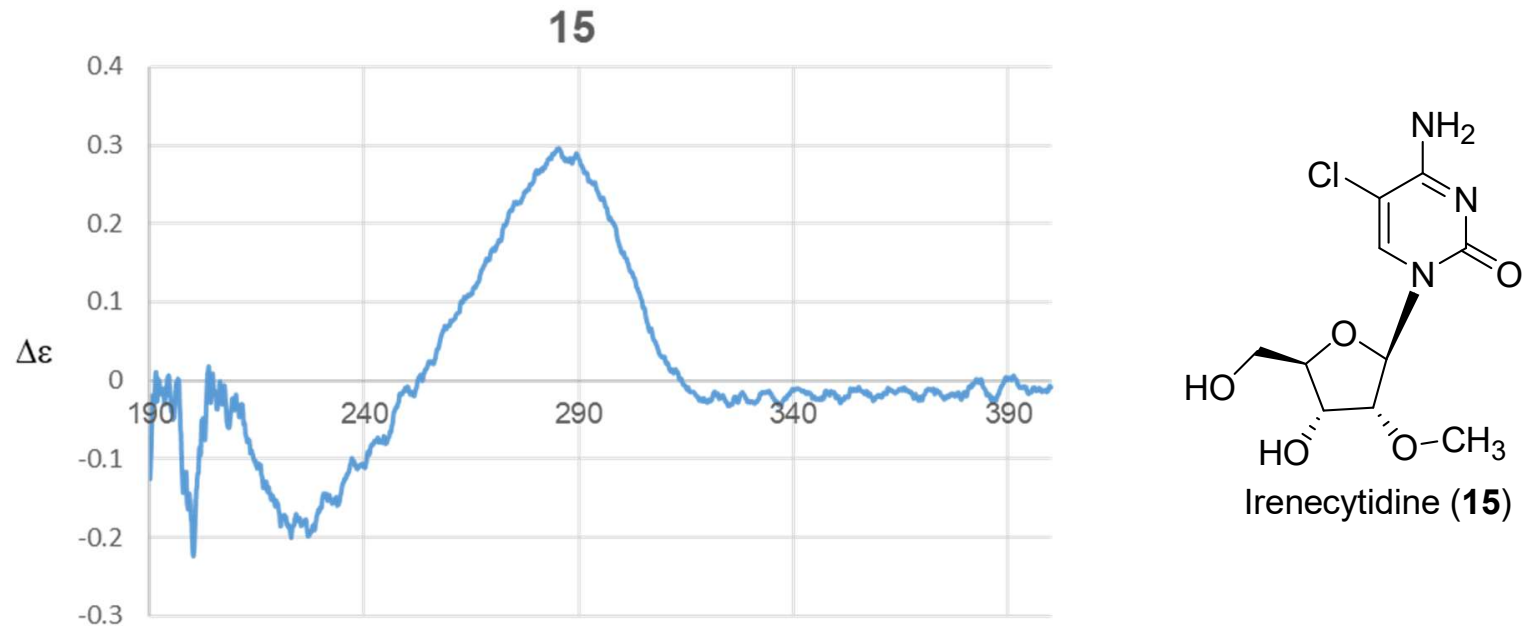

$\mathrm{nm}$

Cytidine
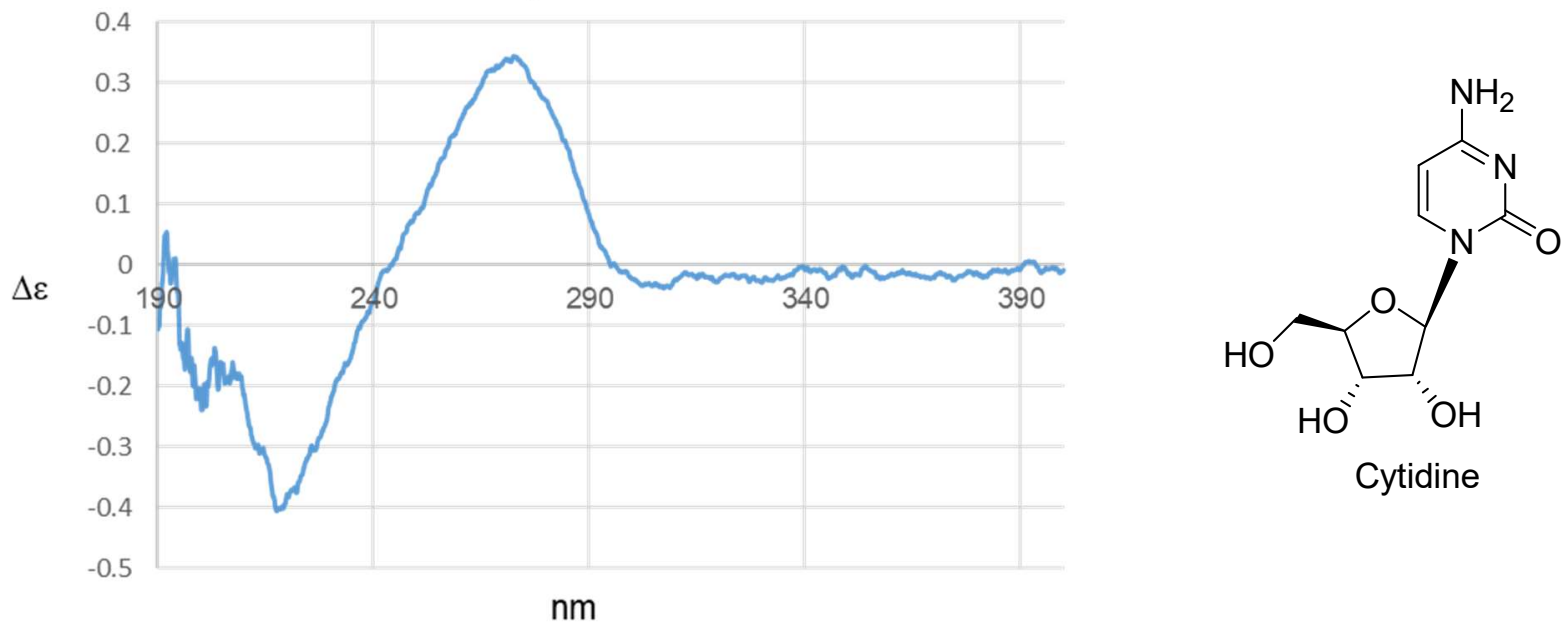

Figure S123. ECD spectra of irenecytidine (15) and authentic cytidine. 
Table S16. NMR data $\left({ }^{1} \mathrm{H}: 400 \mathrm{MHz},{ }^{13} \mathrm{C}: 100 \mathrm{MHz}\right)$ for irenecytidine (15).

\begin{tabular}{cccccc}
$\# \mathrm{C}$ & $\delta_{\mathrm{C}}$ & $\delta_{\mathrm{H}}$ mult. $(J$ in Hz$)$ & COSY & HMBC & NOESY \\
\hline 2 & $152.9, \mathrm{C}$ & & & & \\
4 & $160.9, \mathrm{C}$ & & & & \\
5 & $102.7, \mathrm{C}$ & & & $2,4,5,1^{\prime}$ & $1^{\prime}, 2^{\prime}, 3^{\prime}, 5^{\prime} \mathrm{a}$ \\
6 & $141.8, \mathrm{CH}$ & $8.39, \mathrm{~s}$ & $2^{\prime}$ & $2,6,2^{\prime}$ & $6,2^{\prime}, 4^{\prime}, 6^{\prime}$ \\
$1^{\prime}$ & $89.6, \mathrm{CH}$ & $5.94, \mathrm{~d}(2.7)$ & $1^{\prime}, 3^{\prime}$ & $6^{\prime}$ & $6,1^{\prime}, 3^{\prime}, 6^{\prime}$ \\
$2^{\prime}$ & $84.3, \mathrm{CH}$ & 3.99, overlapped & $2^{\prime}, 4^{\prime}$ & $1^{\prime}, 4^{\prime}, 5^{\prime}$ & $6,2^{\prime}, 5^{\prime} \mathrm{a}, 5^{\prime} \mathrm{b}, 6^{\prime}$ \\
$3^{\prime}$ & $68.6, \mathrm{CH}$ & $4,29, \mathrm{dd}(7.3,5.5)$ & $3^{\prime}, 5^{\prime} \mathrm{a}, 5^{\prime} \mathrm{b}$ & $3^{\prime}$ & $1^{\prime}, 2^{\prime}, 5^{\prime} \mathrm{a}, 5^{\prime} \mathrm{b}$ \\
$4^{\prime}$ & $85.1, \mathrm{CH}$ & $4.11, \mathrm{dt}(7.3,3.5)$ & $4^{\prime}, 5^{\prime} \mathrm{b}$ & & $6,4^{\prime}, 5^{\prime} \mathrm{b}$ \\
$5^{\prime}$ & $60.8, \mathrm{CH} 2$ & $\mathrm{a}: 3.83, \mathrm{dd}(13.0,3.5)$ & $4^{\prime}, 5^{\prime} \mathrm{a}$ & $3^{\prime}, 4^{\prime}$ & $3^{\prime}, 4^{\prime}, 5^{\prime} \mathrm{a}$ \\
& & $\mathrm{b}: 3.98$, overlapped & & $2^{\prime}$ & $6,1^{\prime}, 2^{\prime}, 3^{\prime}$ \\
\hline
\end{tabular}

Measured at $303 \mathrm{~K}$ in $\mathrm{D}_{2} \mathrm{O}$ with a drop of $\mathrm{CD}_{3} \mathrm{OD}$ as internal standard $\left(\delta_{\mathrm{H}} 3.30, \delta_{\mathrm{C}} 49.15 \mathrm{ppm}\right)$.

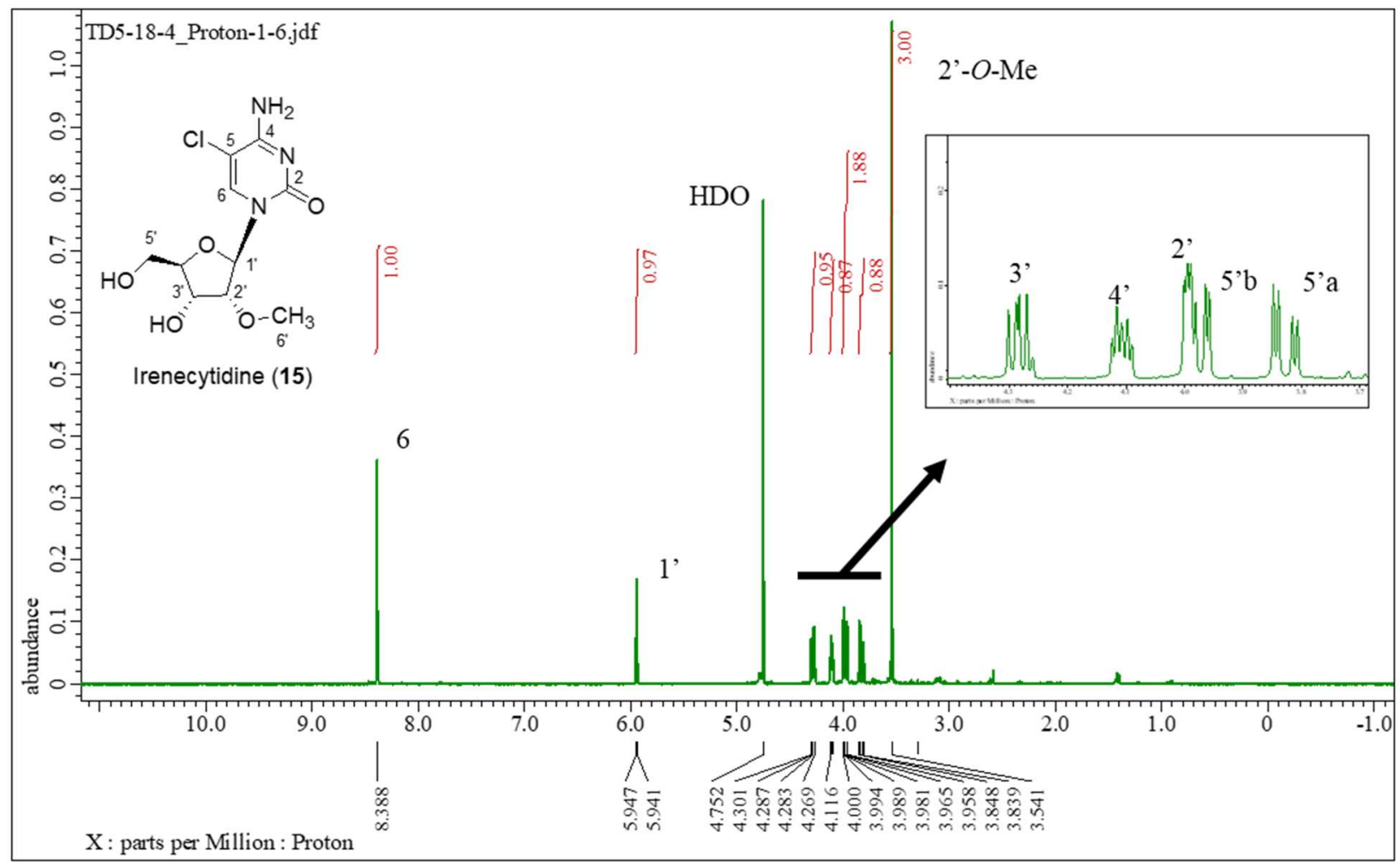

Figure S124. ${ }^{1} \mathrm{H}$ NMR spectrum of irenecytidine (15) in $\mathrm{D}_{2} \mathrm{O}$ with a drop of $\mathrm{CD}_{3} \mathrm{OD}(400 \mathrm{MHz})$. 


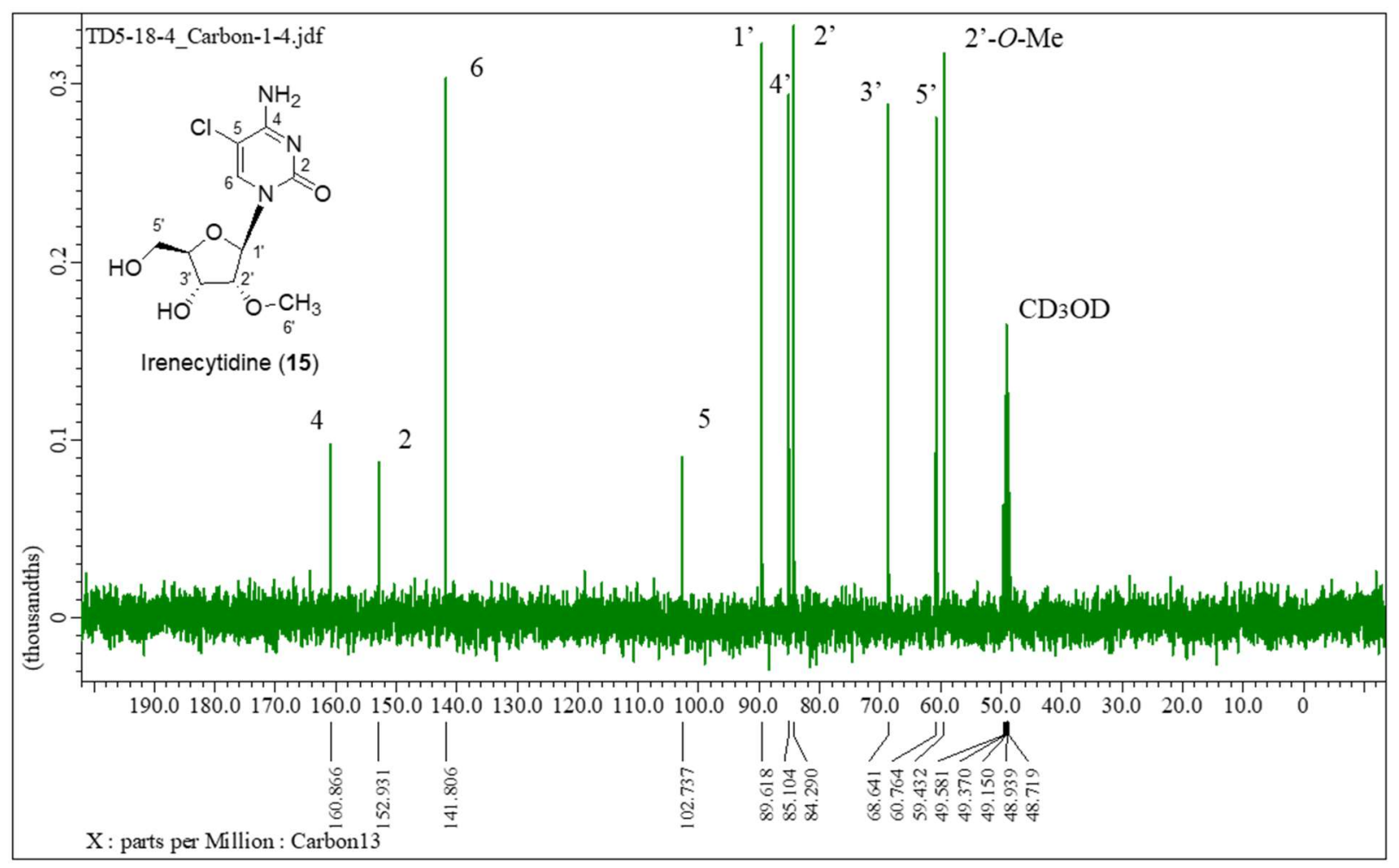

Figure S125. ${ }^{13} \mathrm{C}$ NMR spectrum of irenecytidine (15) in $\mathrm{D}_{2} \mathrm{O}$ with a drop of $\mathrm{CD}_{3} \mathrm{OD}(100 \mathrm{MHz})$.

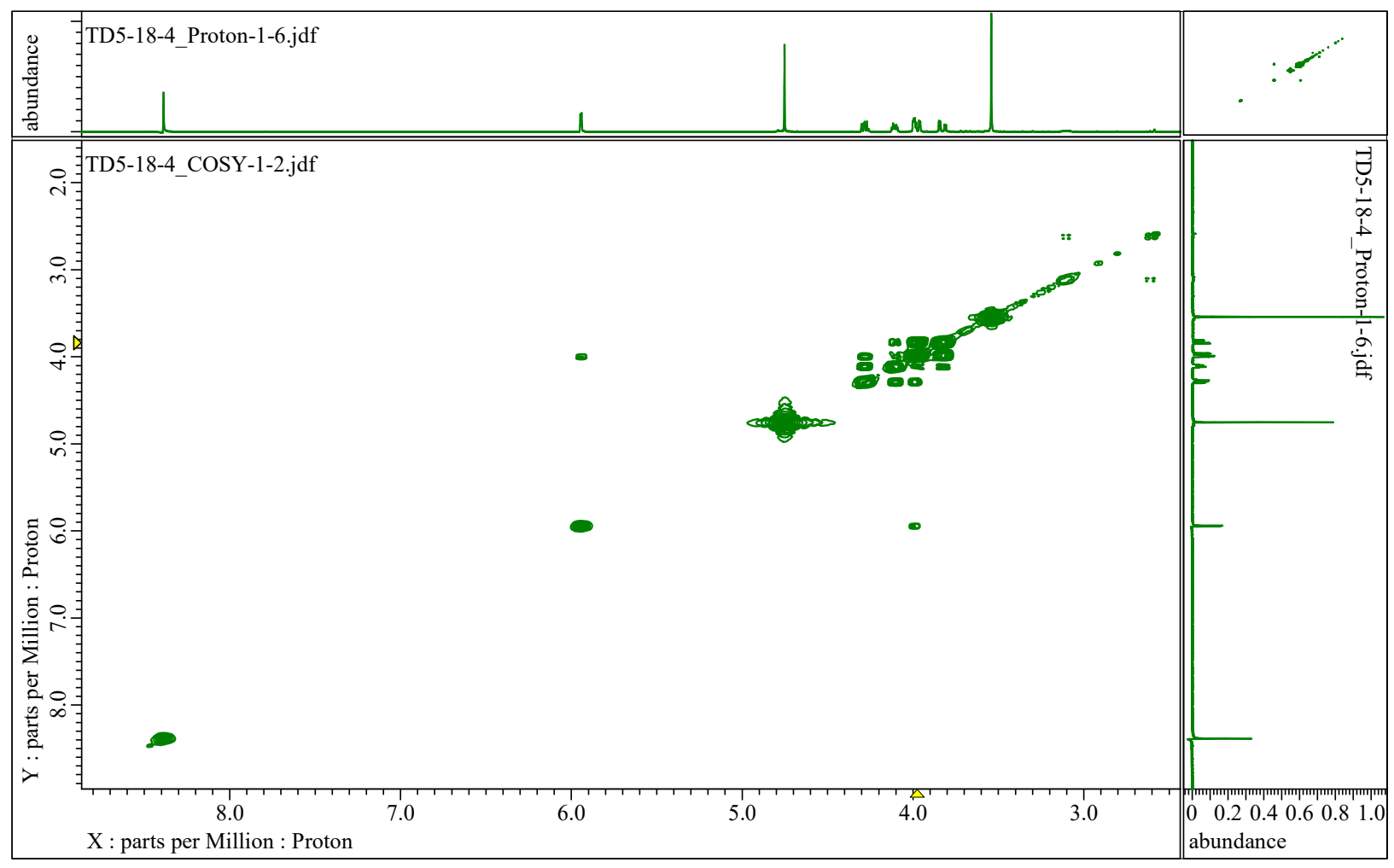

Figure S126. COSY spectrum of irenecytidine (15) in $\mathrm{D}_{2} \mathrm{O}$ with a drop of $\mathrm{CD}_{3} \mathrm{OD}$. 


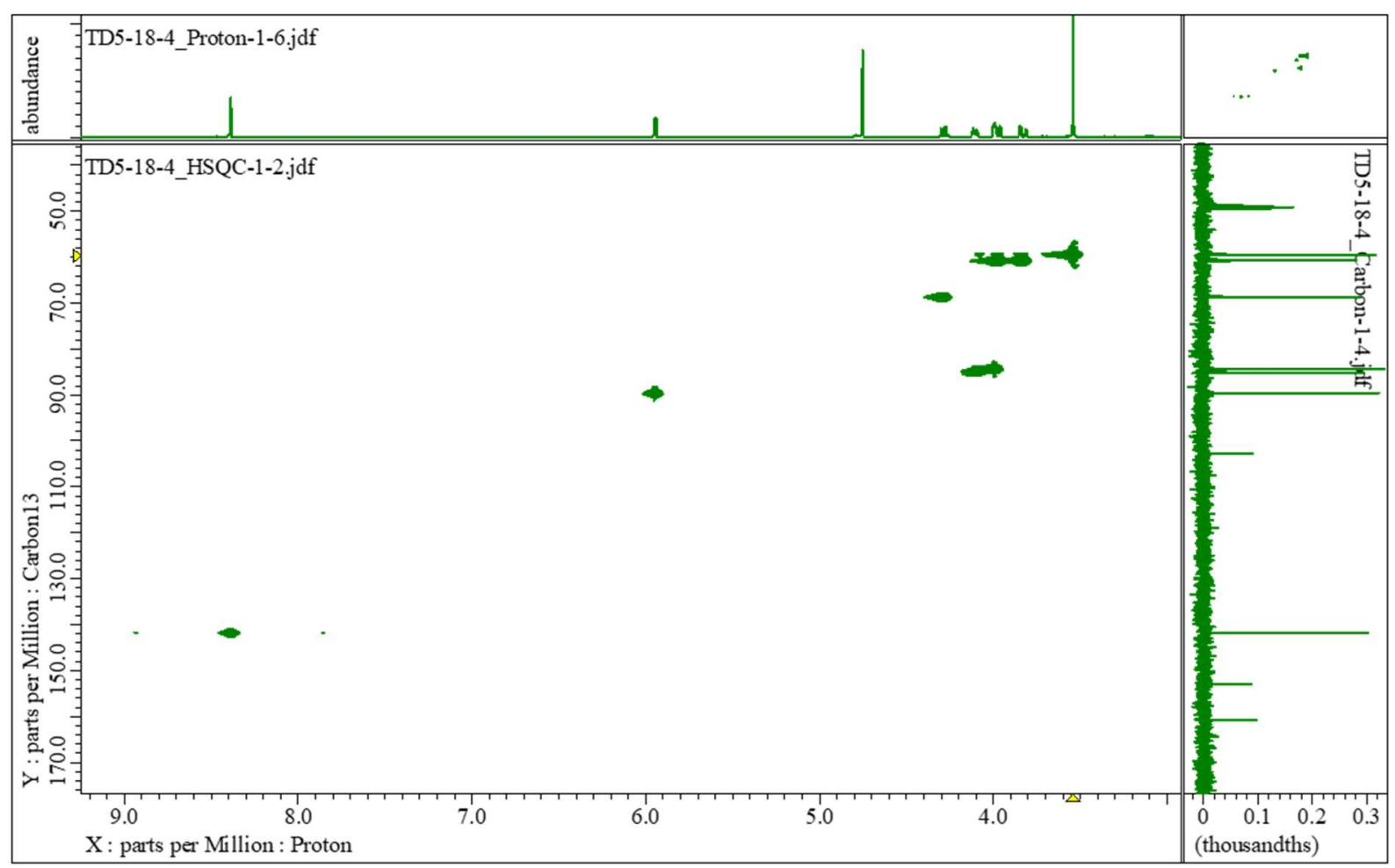

Figure S127. HSQC spectrum of irenecytidine (15) in $\mathrm{D}_{2} \mathrm{O}$ with a drop of $\mathrm{CD}_{3} \mathrm{OD}$.

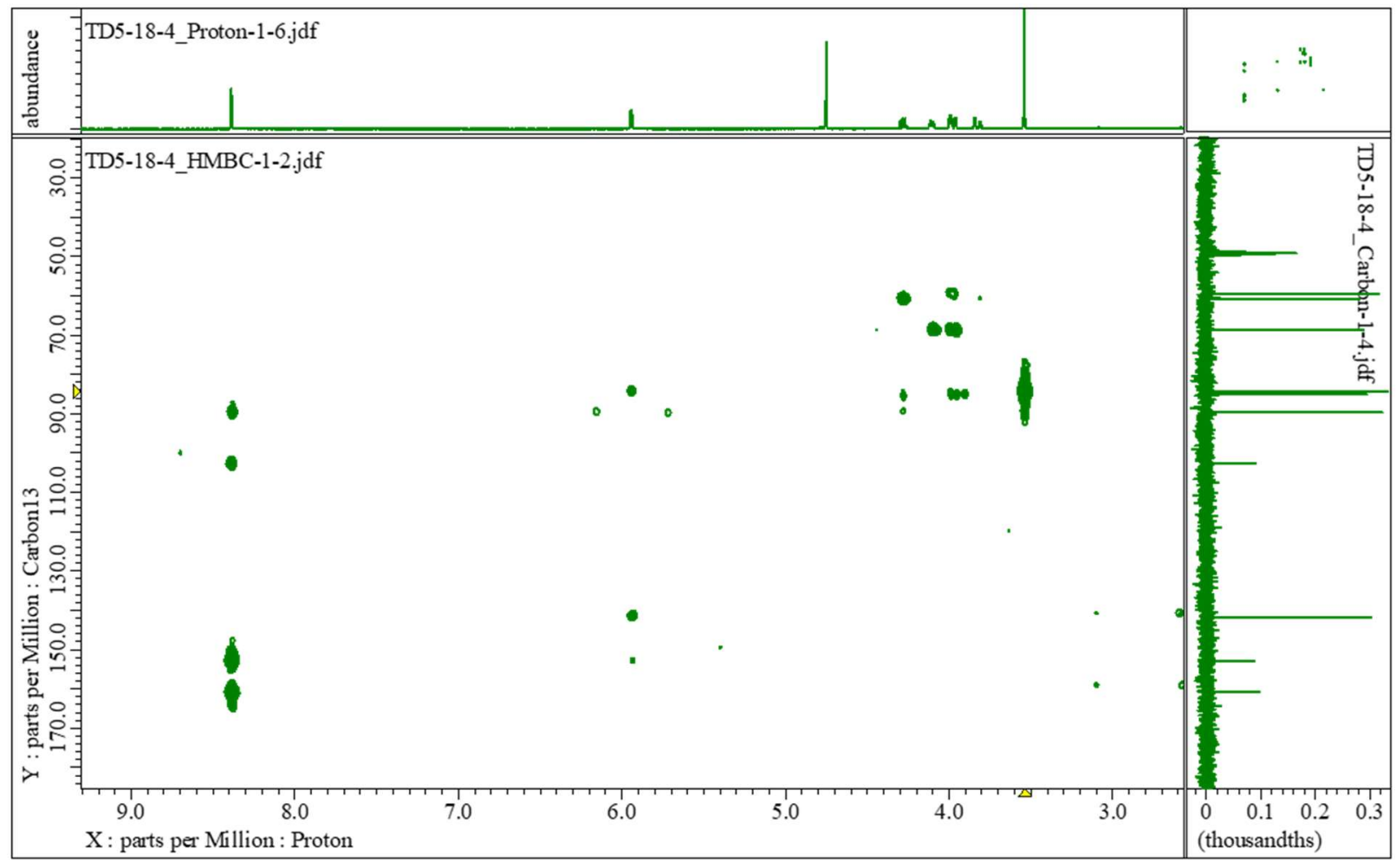

Figure S128. HMBC spectrum of irenecytidine (15) in $\mathrm{D}_{2} \mathrm{O}$ with a drop of $\mathrm{CD}_{3} \mathrm{OD}$. 


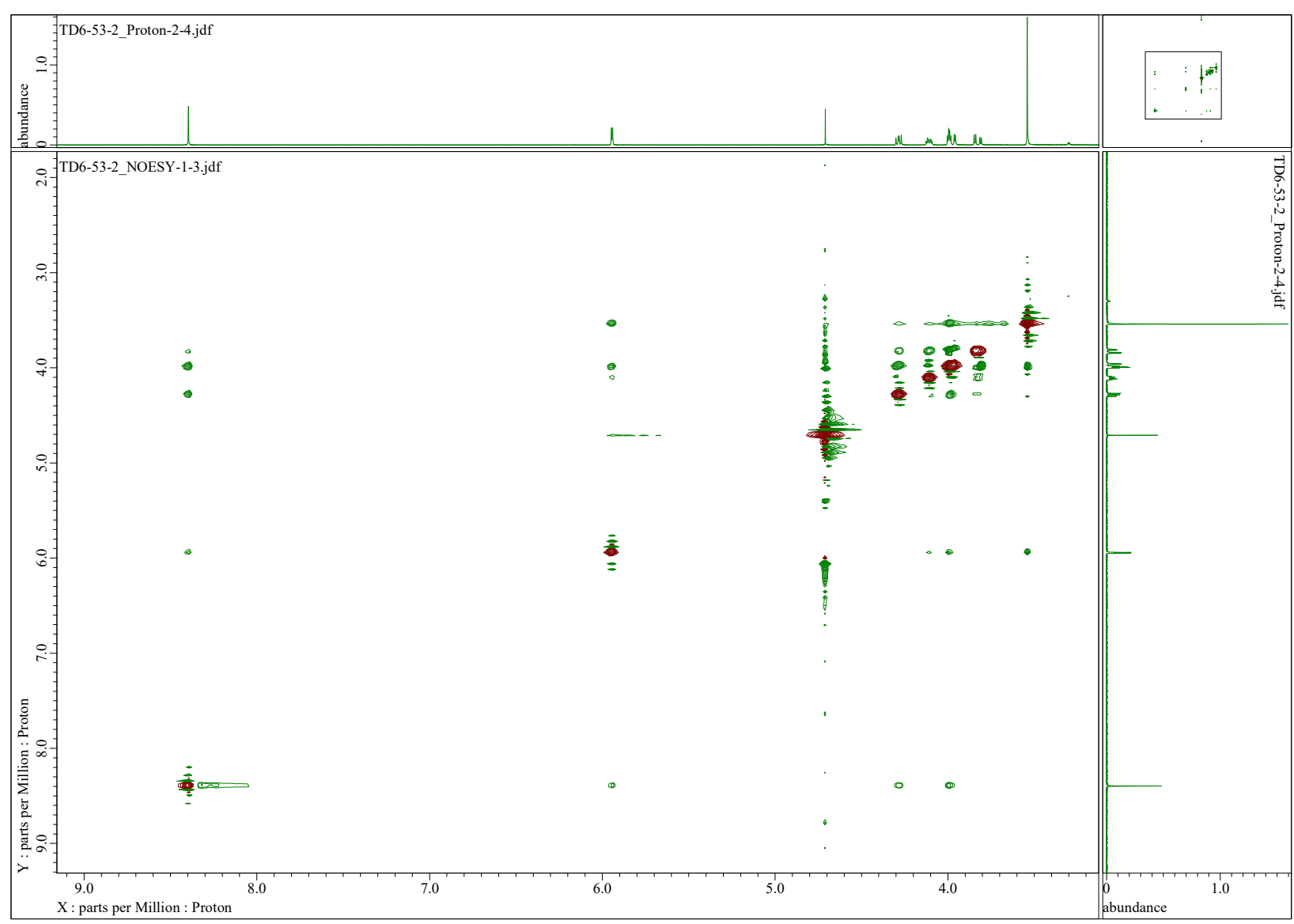

Figure S129. NOESY spectrum of irenecytidine (15) in $\mathrm{D}_{2} \mathrm{O} 10 \mu \mathrm{LCD}_{3} \mathrm{OD}$. 
3.11. Spectral data and NMR assignments for 3-chlorotyramine (16).

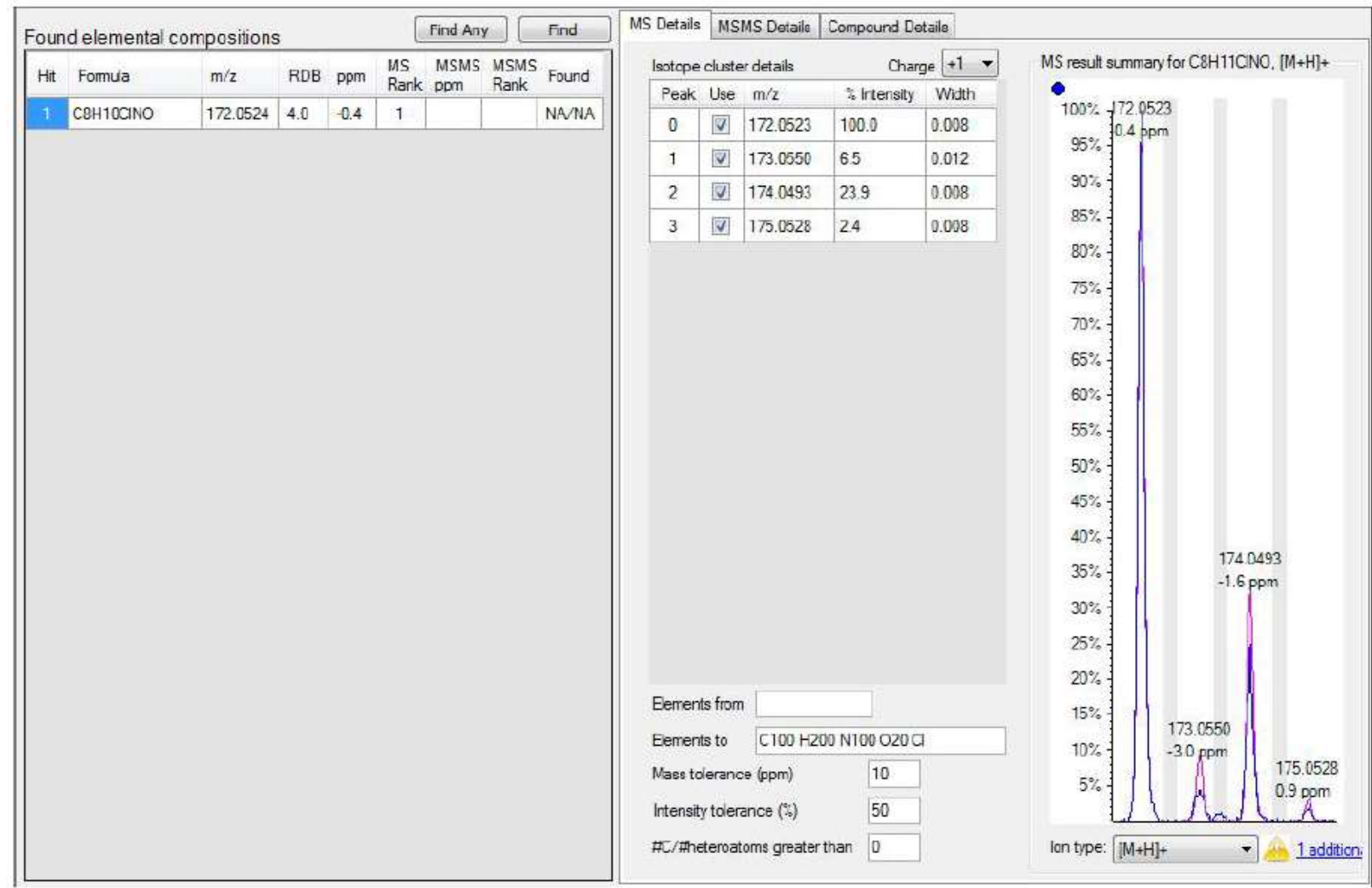

Figure S130. HRESIMS data for 3-chlorotyramine (16).

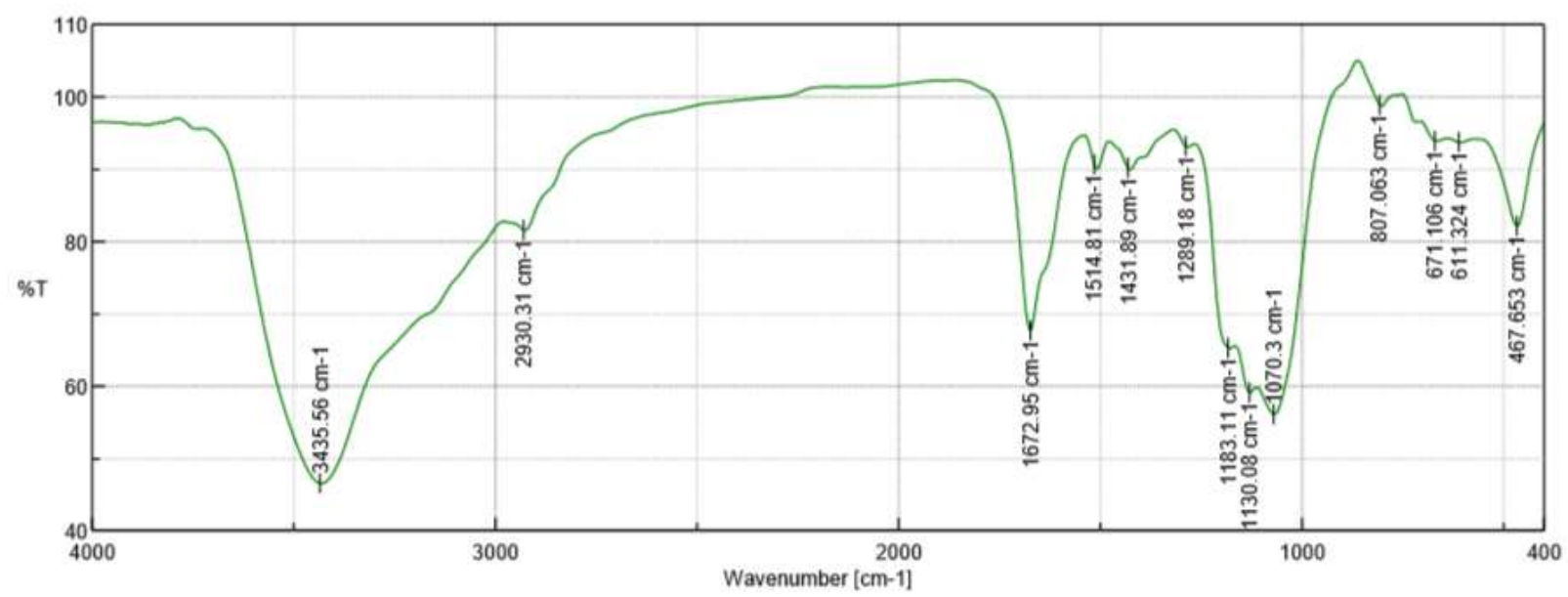

Figure S131. IR spectrum of 3-chlorotyramine (16). 


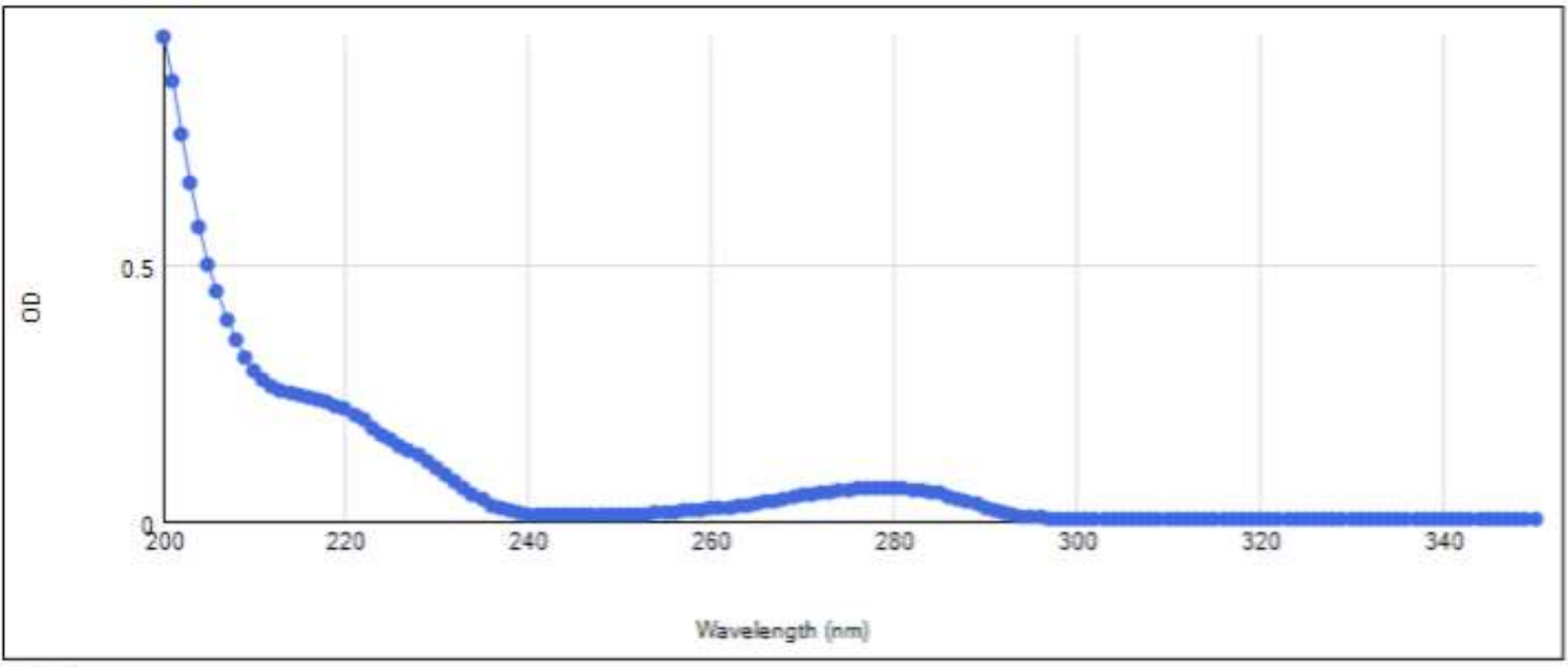

Figure S132. UV spectrum of 2-chlorotyramine (16).

Table S17. NMR data $\left({ }^{1} \mathrm{H}: 400 \mathrm{MHz},{ }^{13} \mathrm{C}: 100 \mathrm{MHz}\right)$ for 3-chlorotyramine (16).

\begin{tabular}{cccccc}
$\# \mathrm{C}$ & $\delta \mathrm{C}$ & $\delta_{\mathrm{H} \text { mult. }(J \text { in } \mathrm{Hz})}$ & $\mathrm{COSY}$ & HMBC & NOESY \\
\hline 1 & $130.8, \mathrm{C}$ & & & & \\
2 & $131.3, \mathrm{CH}$ & $7.33, \mathrm{~d}(1.8)$ & $5(\mathrm{w}), 6,7(\mathrm{w})$ & $3,4,6,7$ & 7,8 \\
3 & $121.5, \mathrm{C}$ & & & & \\
4 & $151.5, \mathrm{C}$ & & & & \\
5 & $118.1, \mathrm{CH}$ & $6.98, \mathrm{~d}(8.2)$ & $2(\mathrm{w}), 5$ & $1,3,4$ & 6 \\
6 & $129.7, \mathrm{CH}$ & $7.11, \mathrm{dd}(8.2,2.3)$ & $2,5,7$ & $3,4,7$ & $5,7,8$ \\
7 & $32.7, \mathrm{CH}_{2}$ & $2.90, \mathrm{t}(7.3)$ & $2(\mathrm{w}), 6(\mathrm{w}), 8$ & 1,8 & $2,6,8$ \\
8 & $41.6, \mathrm{CH}_{2}$ & $3.22, \mathrm{t}(7.3)$ & 7 & 1,7 & $2,6,7$ \\
\hline
\end{tabular}

Measured at $298 \mathrm{~K}$ in $\mathrm{D}_{2} \mathrm{O}$ with $10 \mu \mathrm{L} \mathrm{CD} \mathrm{CDD}_{3} \mathrm{O}$ as internal standard $\left(\delta_{\mathrm{H}} 3.30, \delta_{\mathrm{C}} 49.15 \mathrm{ppm}\right)$. $\mathrm{w}=$ weak signal. 


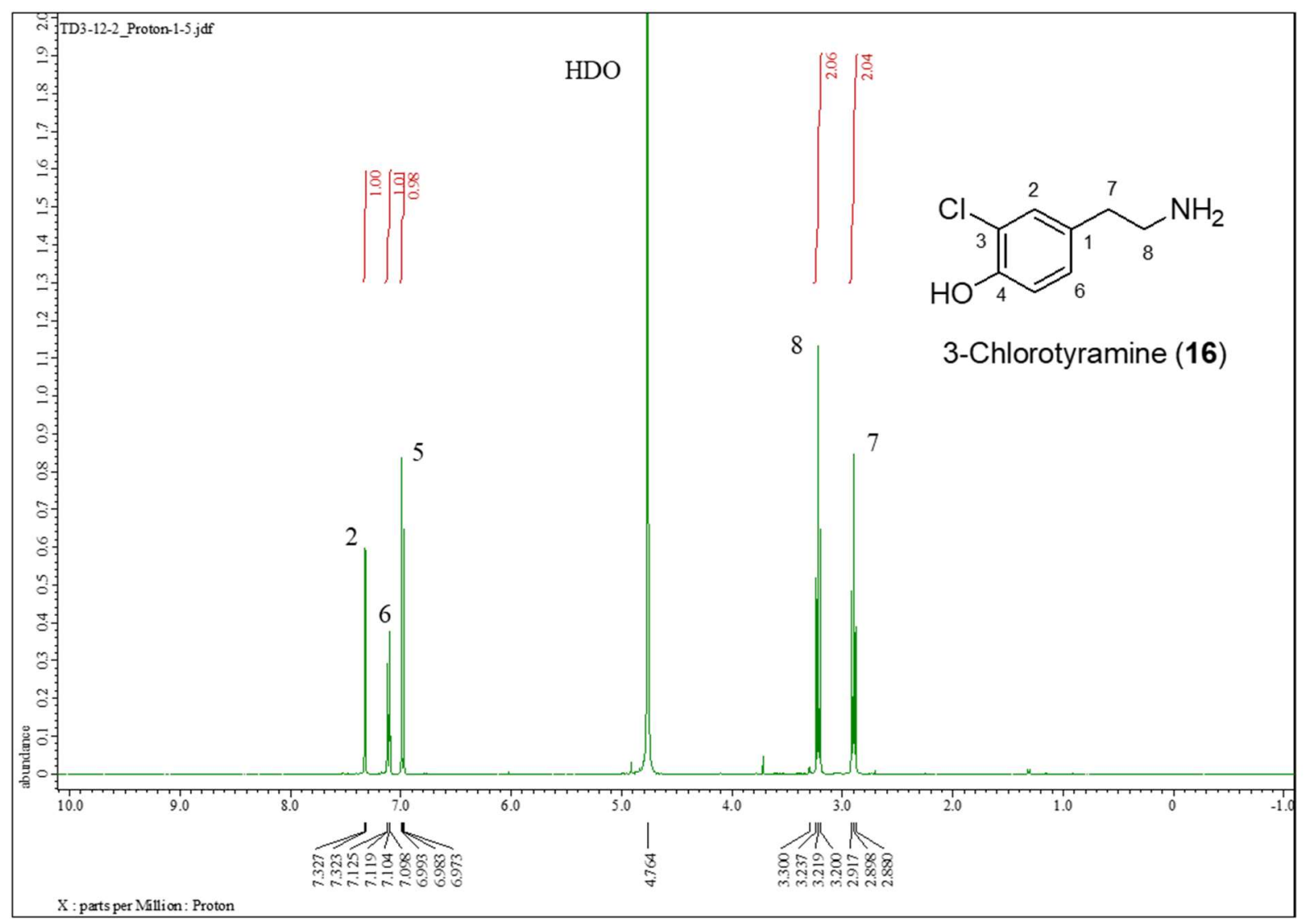

Figure S133. ${ }^{1} \mathrm{H}$ NMR spectrum of 3-chlorotyramine (16) in $\mathrm{D}_{2} \mathrm{O}$ with $10 \mu \mathrm{L} \mathrm{CD} 3 \mathrm{OD}(400 \mathrm{MHz})$.

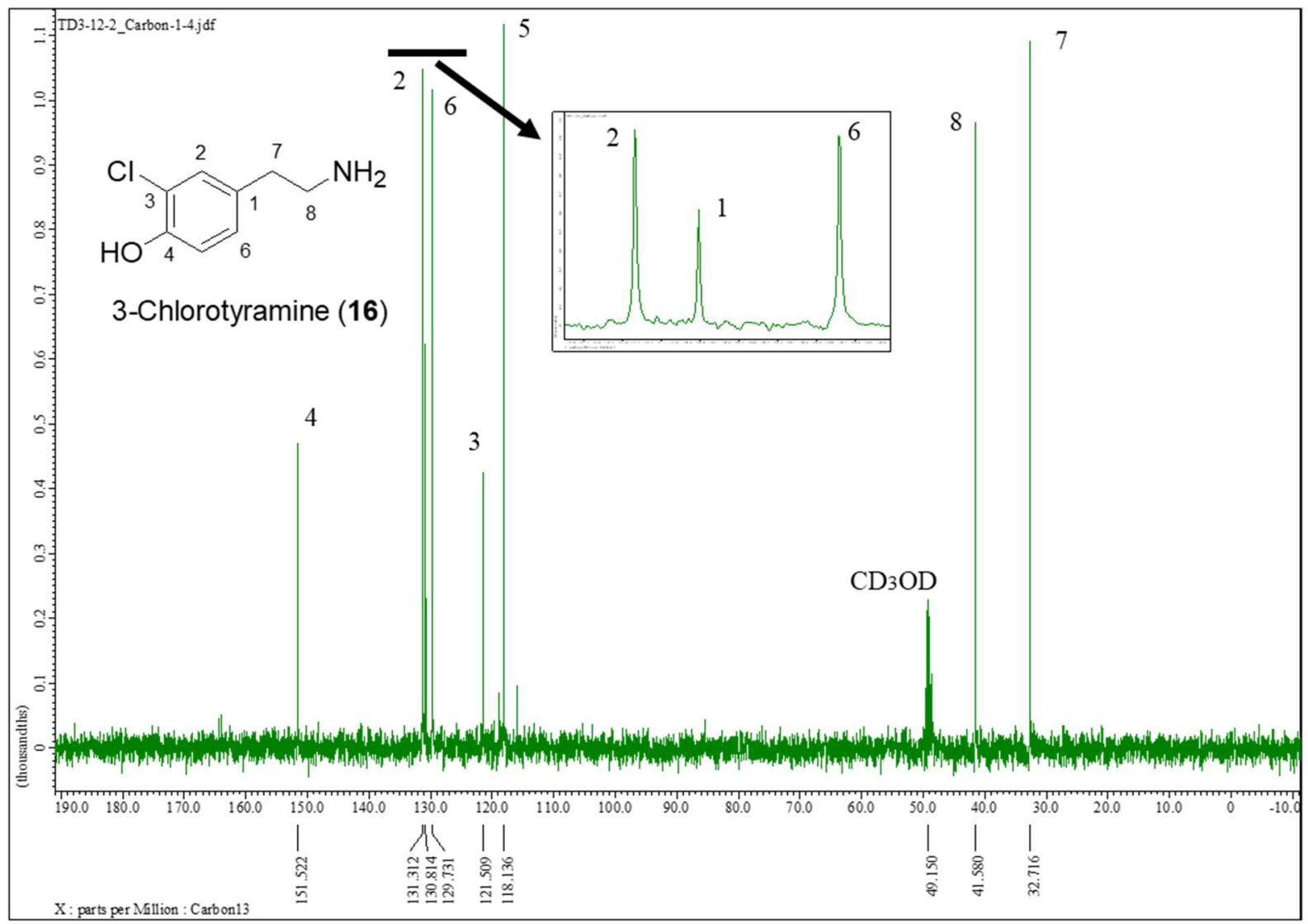

Figure S134. ${ }^{13} \mathrm{C}$ NMR spectrum of 3-chlorotyramine (16) in $\mathrm{D}_{2} \mathrm{O}$ with $10 \mu \mathrm{L} \mathrm{CD} \mathrm{CD}_{3} \mathrm{OD}(100 \mathrm{MHz})$. 


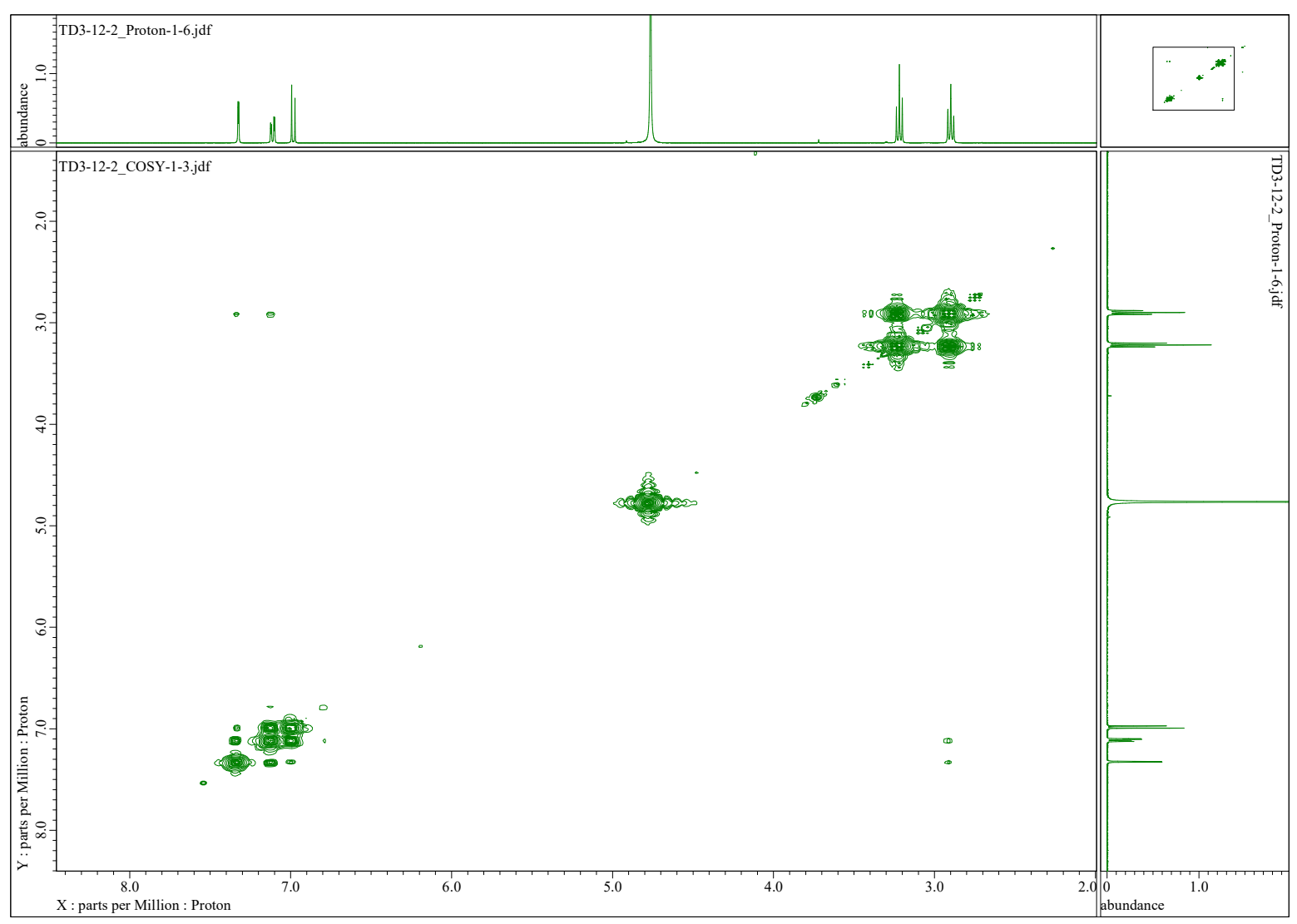

Figure S135. COSY spectrum of 3-chlorotyramine (16) in $\mathrm{D}_{2} \mathrm{O}$ with $10 \mu \mathrm{L} \mathrm{CD}_{3} \mathrm{OD}$.

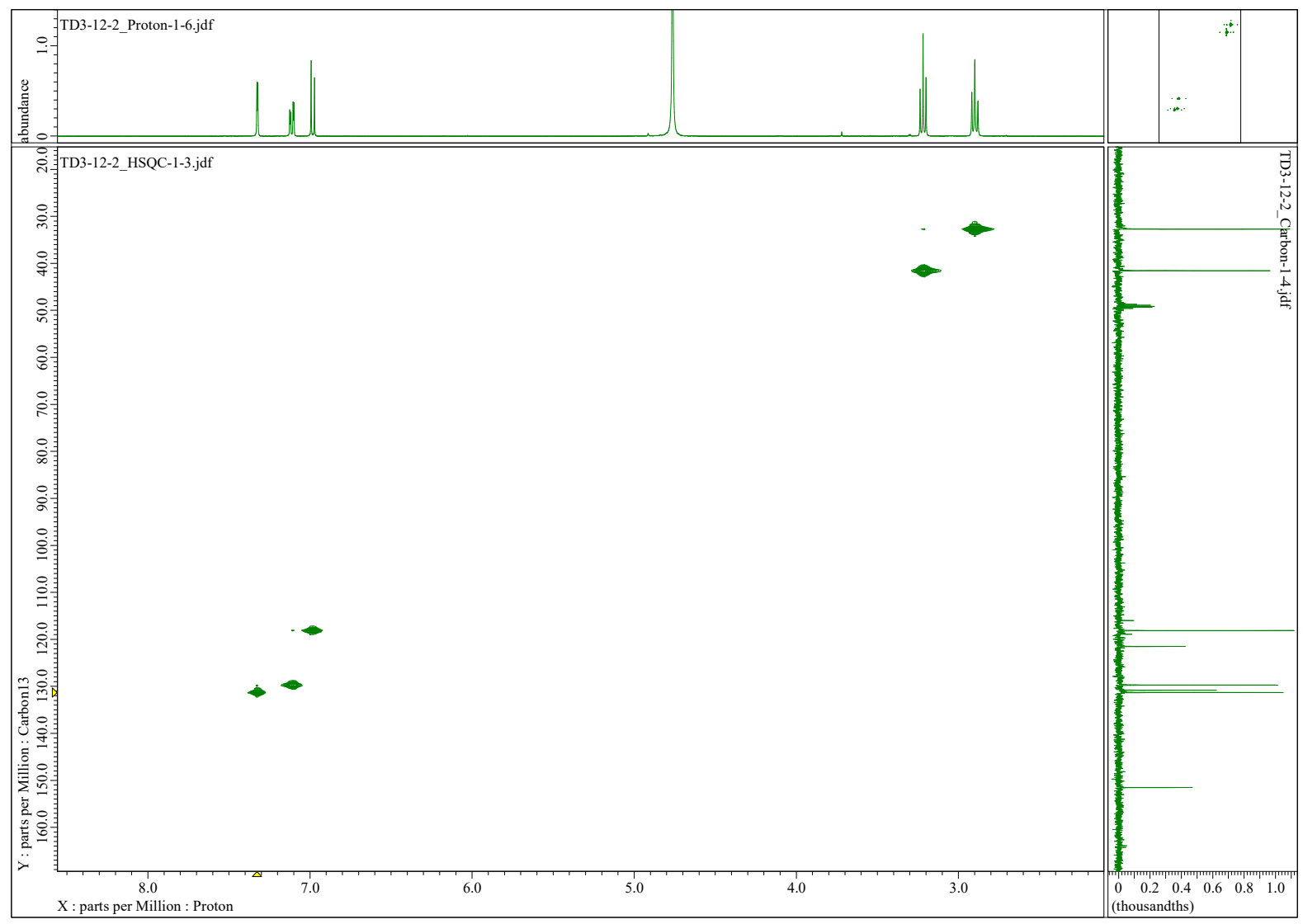

Figure S136. HSQC spectrum of 3-chlorotyramine (16) in $\mathrm{D}_{2} \mathrm{O}$ with $10 \mu \mathrm{L} \mathrm{CD}_{3} \mathrm{OD}$. 


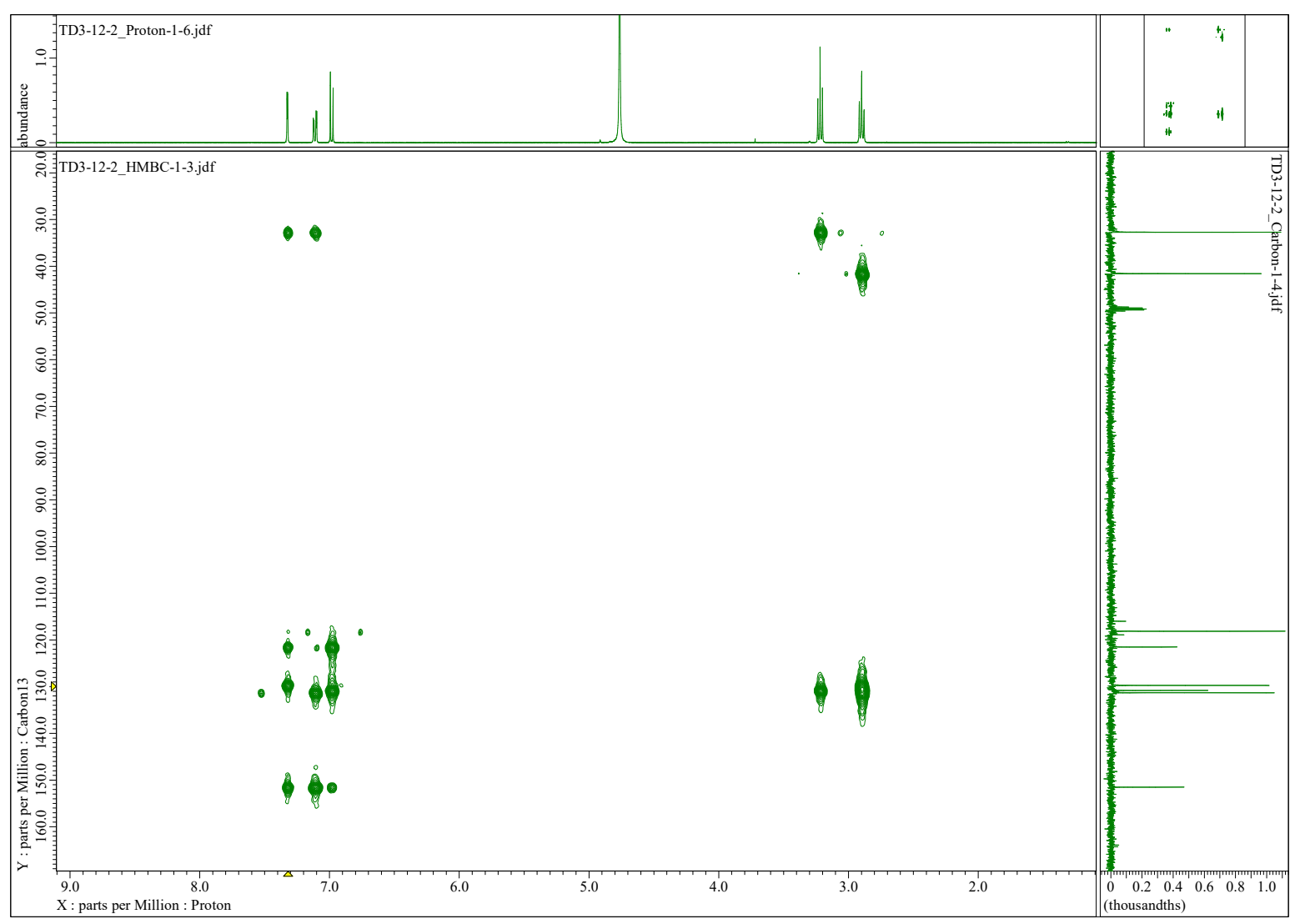

Figure S137. HMBC spectrum of 3-chlorotyramine (16) in $\mathrm{D}_{2} \mathrm{O}$ with $10 \mu \mathrm{L} \mathrm{CD}_{3} \mathrm{OD}$.

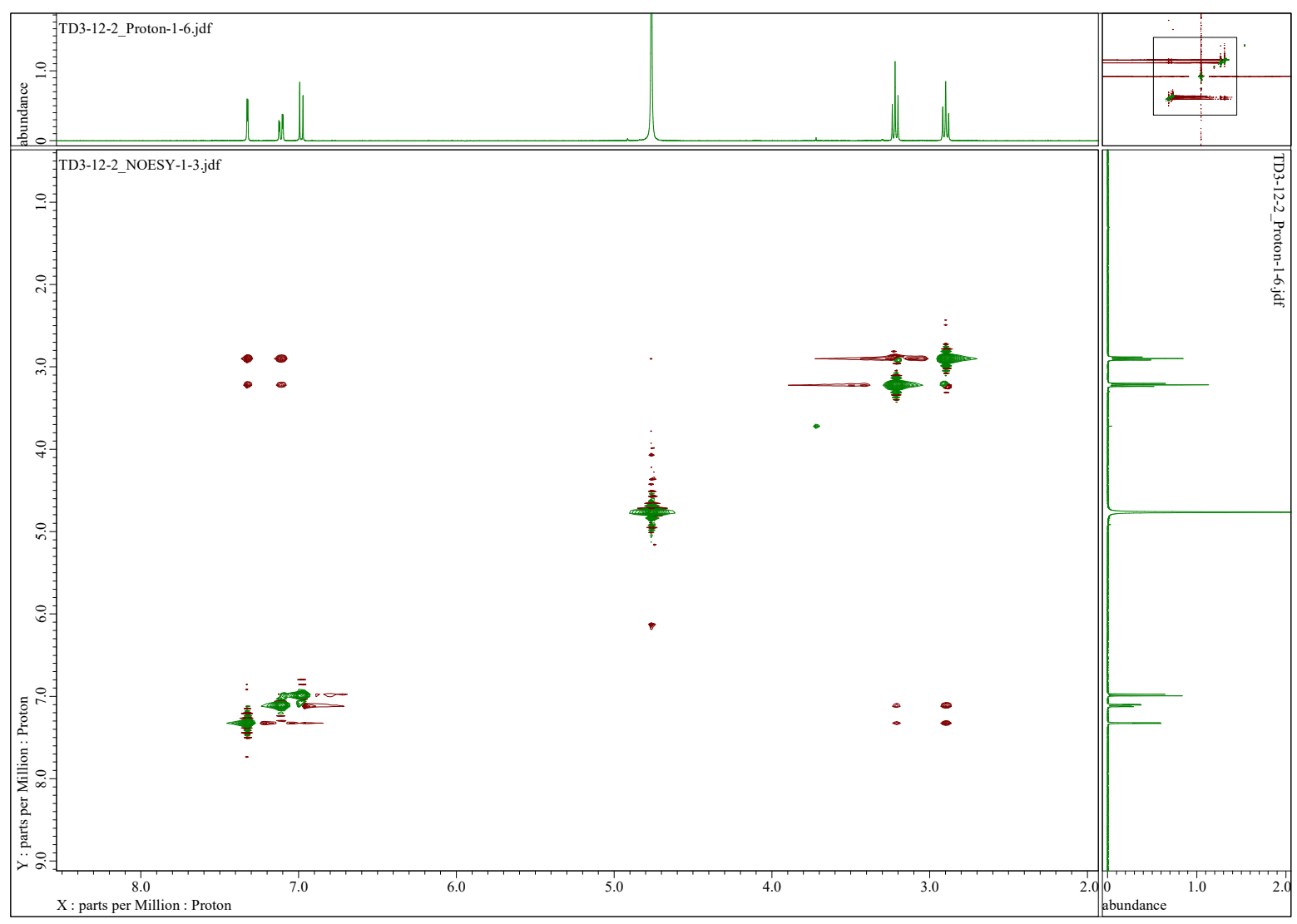

Figure S138. NOESY spectrum of 3-chlorotyramine (16) in $\mathrm{D}_{2} \mathrm{O}$ with $10 \mu \mathrm{L} \mathrm{CD} \mathrm{CD}_{3} \mathrm{OD}$. 
3.12. Physicochemical properties, spectral data and NMR assignments for 3-bromotyramine (17).

3-Bromotyramine (17), white solid: UV ( $\left.\mathrm{H}_{2} \mathrm{O}\right) \lambda_{\max }(\log \varepsilon) 279(3.03) \mathrm{nm}$; IR (KBr) $v_{\max } 3435,1680,1635,1130$, 1070, $475 \mathrm{~cm}^{-1}$; ${ }^{1} \mathrm{H}$ NMR ( $\mathrm{D}_{2} \mathrm{O}$ with $10 \mu \mathrm{L} \mathrm{CD}_{3} \mathrm{OD}, 400 \mathrm{MHz}$ ) and ${ }^{13} \mathrm{C}$ NMR (100 MHz) (Table S18); HRESIMS $m / z 216.0020[\mathrm{M}+\mathrm{H}]^{+}$(calcd for $\left.\mathrm{C}_{8} \mathrm{H}_{11} \mathrm{BrNO}, m / z 216.0019\right)$.

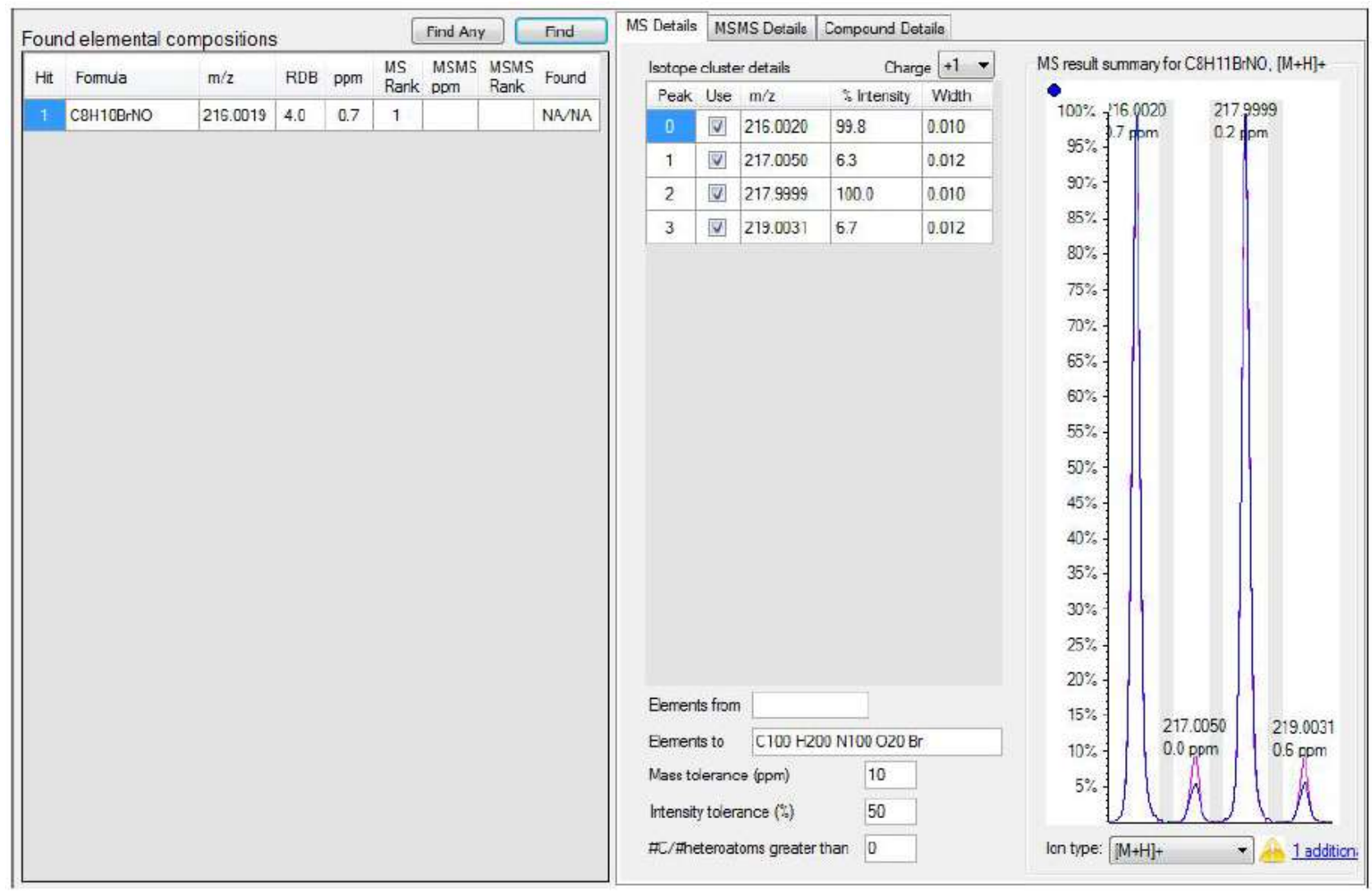

Figure S139. HRESIMS data for 3-bromotyramine (17). 


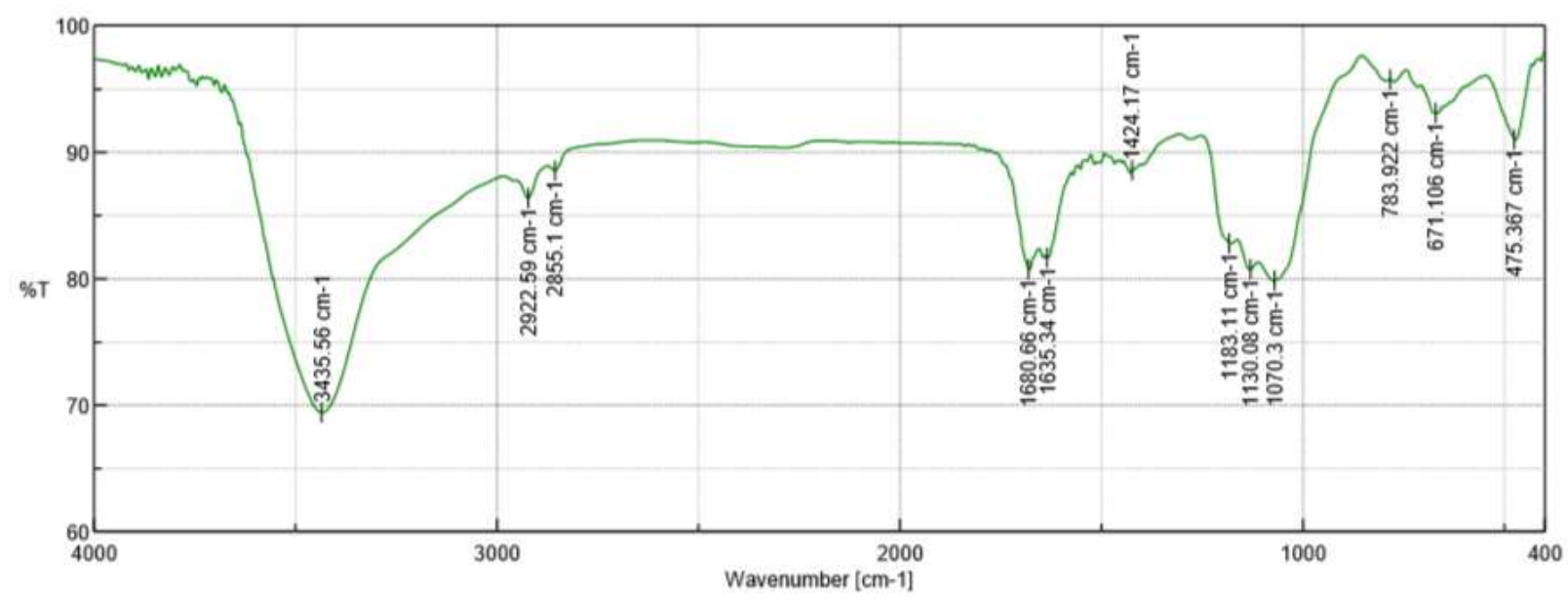

Figure S140. IR spectrum of 3-bromotyramine (17).

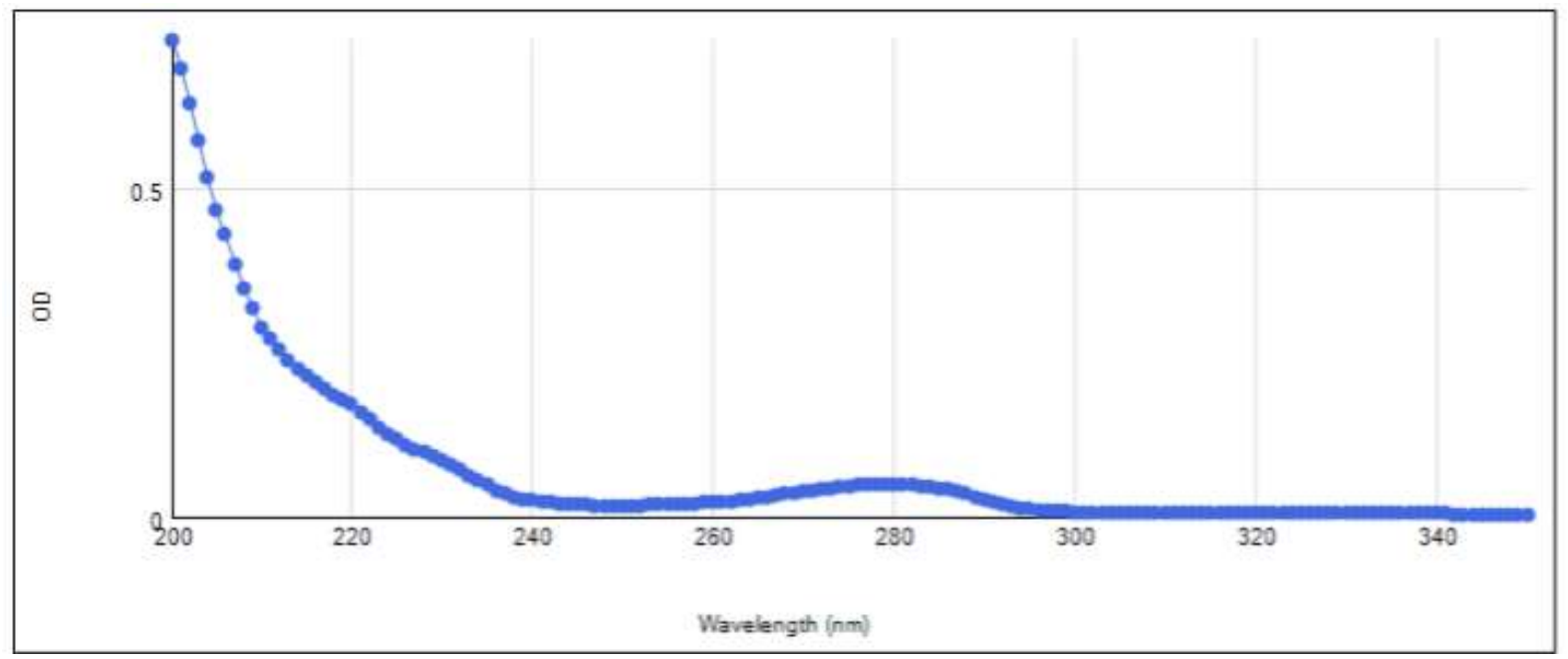

Figure S141. UV spectrum of 2-bromotyramine (17).

Table S18. NMR data $\left({ }^{1} \mathrm{H}: 400 \mathrm{MHz},{ }^{13} \mathrm{C}\right.$ : $\left.100 \mathrm{MHz}\right)$ for 3-bromotyramine (17).

\begin{tabular}{cccccc}
$\# \mathrm{C}$ & $\delta_{\mathrm{C}}$ & $\delta_{\mathrm{H}}$ mult. $(J$ in Hz) & COSY & HMBC & NOESY \\
\hline 1 & $131.2, \mathrm{C}$ & & & & \\
2 & $134.4, \mathrm{CH}$ & $7.51, \mathrm{~d}(2.3)$ & $6(\mathrm{w})$ & $3,4,6,7$ & 7,8 \\
3 & $110.7, \mathrm{C}$ & & & & \\
4 & $152.6, \mathrm{C}$ & & & & 6 \\
5 & $117.9, \mathrm{CH}$ & $6.99, \mathrm{~d}(8.2)$ & 6 & $1,2,4$ & $5,7,8$ \\
6 & $130.5, \mathrm{CH}$ & $7.17, \mathrm{dd}(8.2,2.3)$ & $2(\mathrm{w}), 5$ & $2,3(\mathrm{w}), 4,5(\mathrm{w}), 7$ & $3,5,8$ \\
7 & $32.6, \mathrm{CH}_{2}$ & $2.90, \mathrm{t}(7.3)$ & 8 & $3,4,5,8$ & $3(\mathrm{w}), 5(\mathrm{w}), 7$ \\
\hline & $41.6, \mathrm{CH}_{2}$ & $3.22, \mathrm{t}(7.3)$ & 7 & 4,7 & \\
\hline
\end{tabular}

Measured at $298 \mathrm{~K}$ in $\mathrm{D}_{2} \mathrm{O}$ with $10 \mu \mathrm{L} \mathrm{CD}_{3} \mathrm{OD}$ as internal standard $\left(\delta_{\mathrm{H}} 3.30, \delta_{\mathrm{C}} 49.15 \mathrm{ppm}\right)$. 
Table S19. NMR data comparison of 3-bromotyramine (17) with reported data.

\begin{tabular}{|c|c|c|c|c|c|c|}
\hline \multirow{2}{*}{$\# \mathrm{C}$} & \multicolumn{2}{|r|}{17} & \multicolumn{2}{|c|}{ 3-Bromotyramine (Ref) ${ }^{4}$} & \multirow{2}{*}{$\begin{array}{c}\Delta \delta_{\mathrm{C}} \\
(17-\mathrm{Ref})\end{array}$} & \multirow{2}{*}{$\begin{array}{c}\Delta \delta_{\mathrm{H}} \\
(17-\mathrm{Ref})\end{array}$} \\
\hline & $\delta_{\mathrm{C}}$ & $\delta_{\mathrm{H}}$ mult. $(J$ in $\mathrm{Hz})$ & $\delta_{\mathrm{C}}$ & $\delta_{\mathrm{H}}$ mult. $(J$ in $\mathrm{Hz})$ & & \\
\hline 1 & $131.2, \mathrm{C}$ & & $130.3, \mathrm{C}$ & & 0.9 & \\
\hline 2 & $134.4, \mathrm{CH}$ & 7.51, d (2.3) & 134.3, $\mathrm{CH}$ & $7.39, \mathrm{~d}(2.1)$ & 0.1 & 0.12 \\
\hline 3 & $110.7, \mathrm{C}$ & & 111.1, C & & -0.4 & \\
\hline 4 & $152.6, \mathrm{C}$ & & 154.7, C & & -2.1 & \\
\hline 5 & $117.9, \mathrm{CH}$ & $6.99, \mathrm{~d}(8.2)$ & 117.7, $\mathrm{CH}$ & $6.87, \mathrm{~d}(8.3)$ & 0.2 & 0.12 \\
\hline 6 & $130.5, \mathrm{CH}$ & 7.17, dd $(8.2,2.3)$ & $130.0, \mathrm{CH}$ & 7.07, dd $(8.3,2.1)$ & 0.5 & 0.1 \\
\hline 7 & $32.6, \mathrm{CH}_{2}$ & $2.90, \mathrm{t}(7.3)$ & $33.3, \mathrm{CH}_{2}$ & $2.84, \mathrm{t}(7.7)$ & -0.7 & 0.06 \\
\hline 8 & $41.6, \mathrm{CH}_{2}$ & $3.22, \mathrm{t}(7.3)$ & $42.0, \mathrm{CH}_{2}$ & $3.11, \mathrm{t}(7.7)$ & -0.4 & 0.11 \\
\hline
\end{tabular}

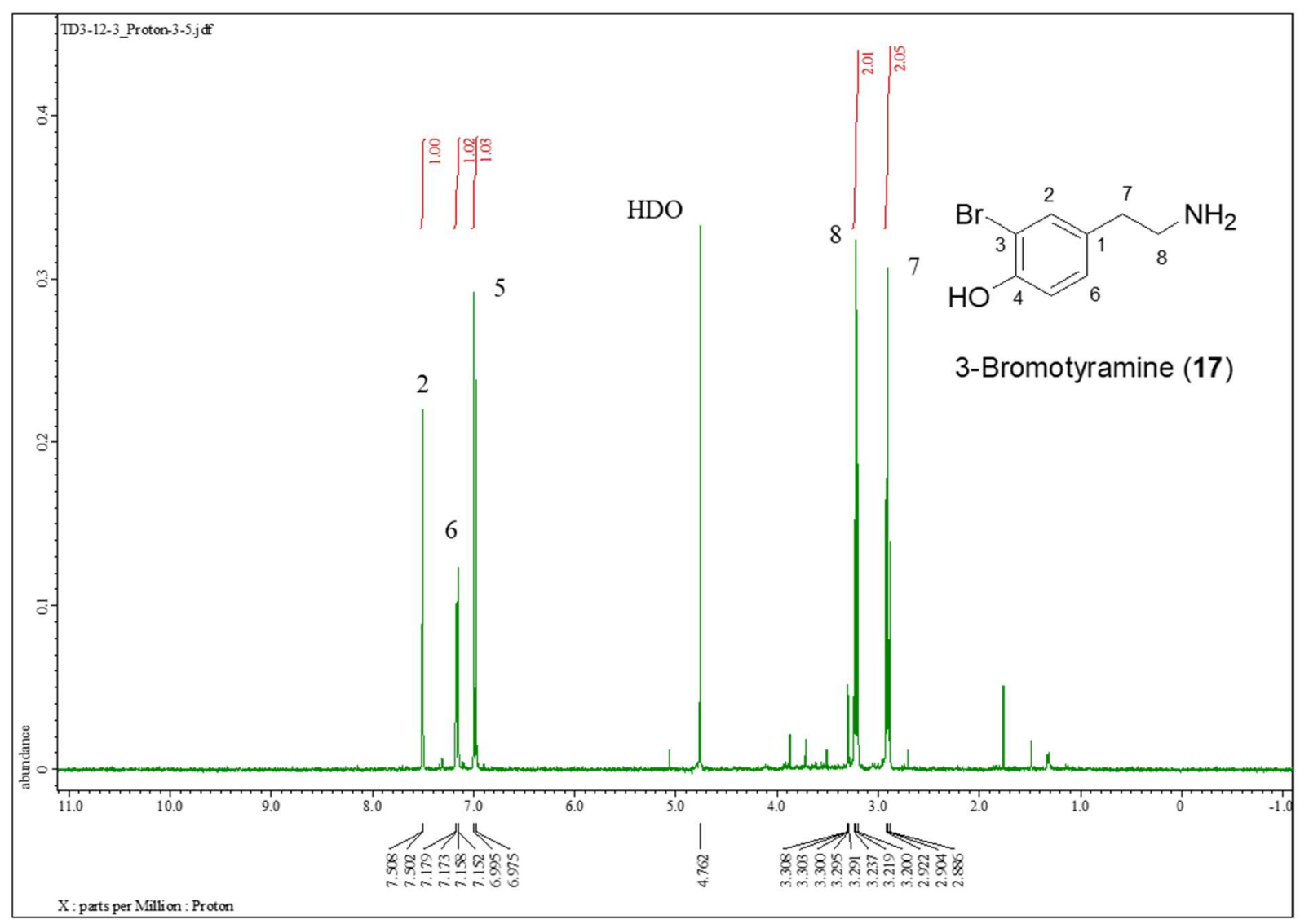

Figure S142. ${ }^{1} \mathrm{H}$ NMR spectrum of 3-bromotyramine (17) in $\mathrm{D}_{2} \mathrm{O}$ with $10 \mu \mathrm{L} \mathrm{CD}_{3} \mathrm{OD}$ (400 MHz). 


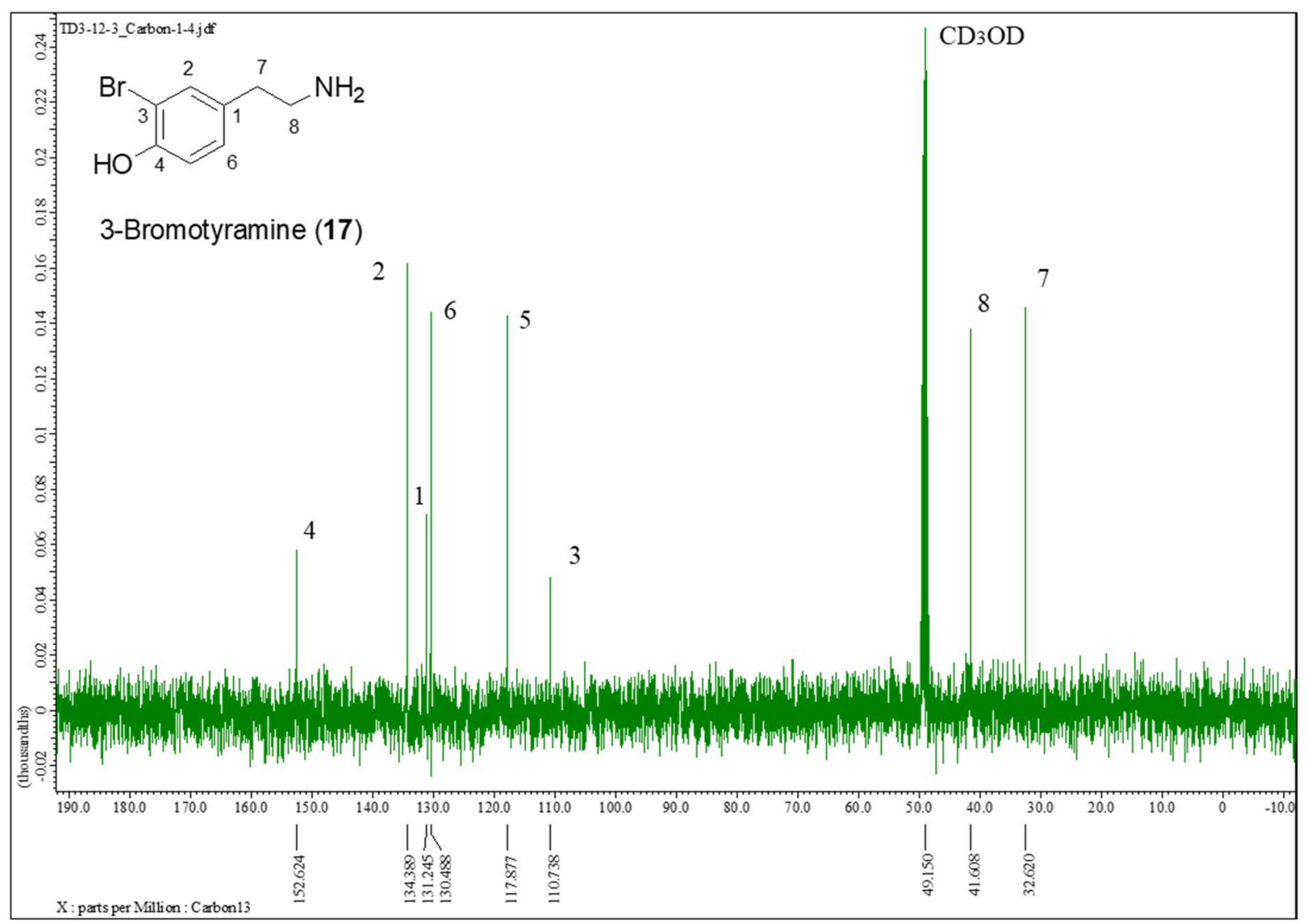

Figure S143. ${ }^{13} \mathrm{C}$ NMR spectrum of 3-bromotyramine (17) in $\mathrm{D}_{2} \mathrm{O}$ with $10 \mu \mathrm{LCD}_{3} \mathrm{OD}(100 \mathrm{MHz})$.

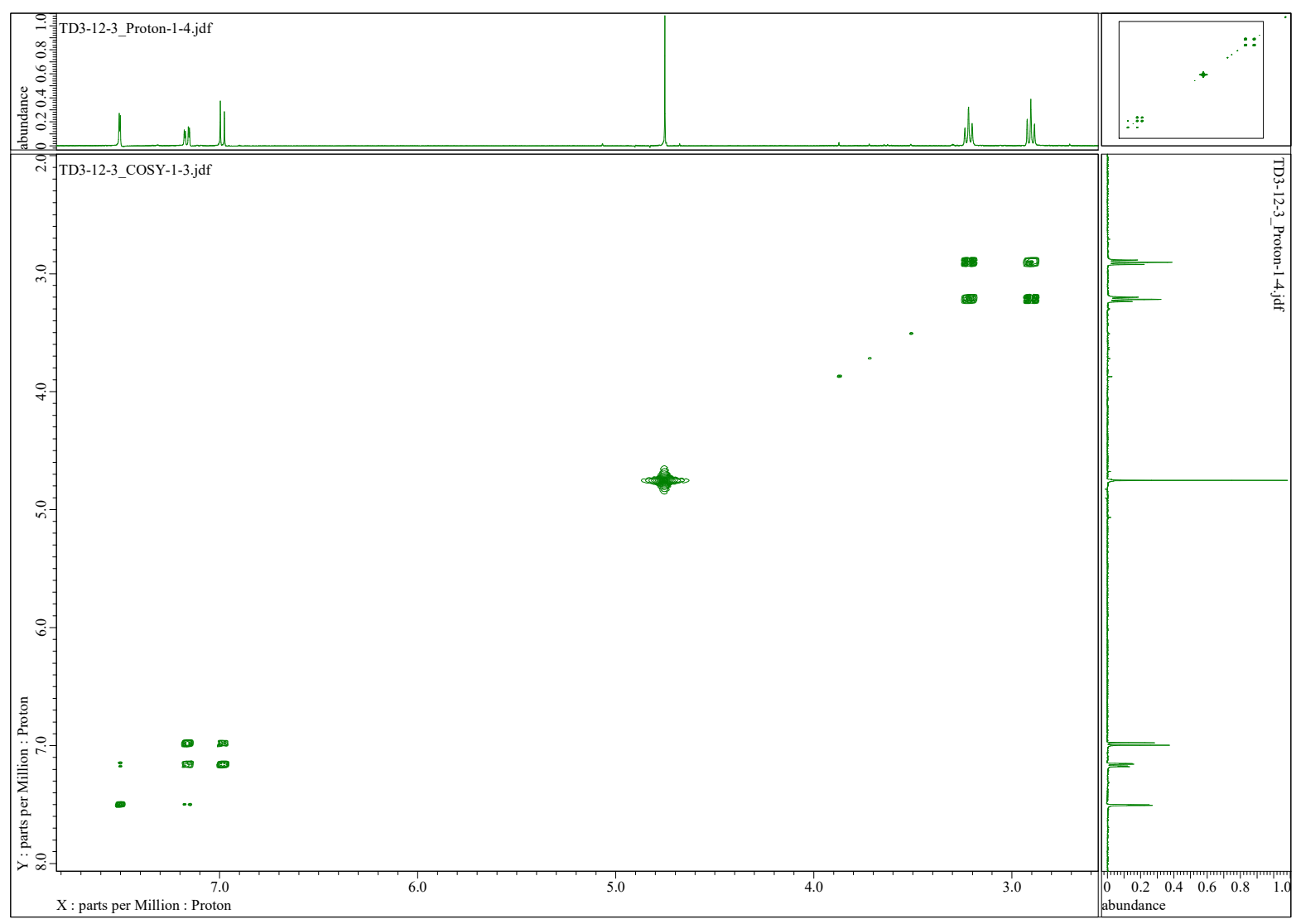

Figure S144. COSY spectrum of 3-bromotyramine (17) in $\mathrm{D}_{2} \mathrm{O}$ with $10 \mu \mathrm{L} \mathrm{CD}_{3} \mathrm{OD}$. 


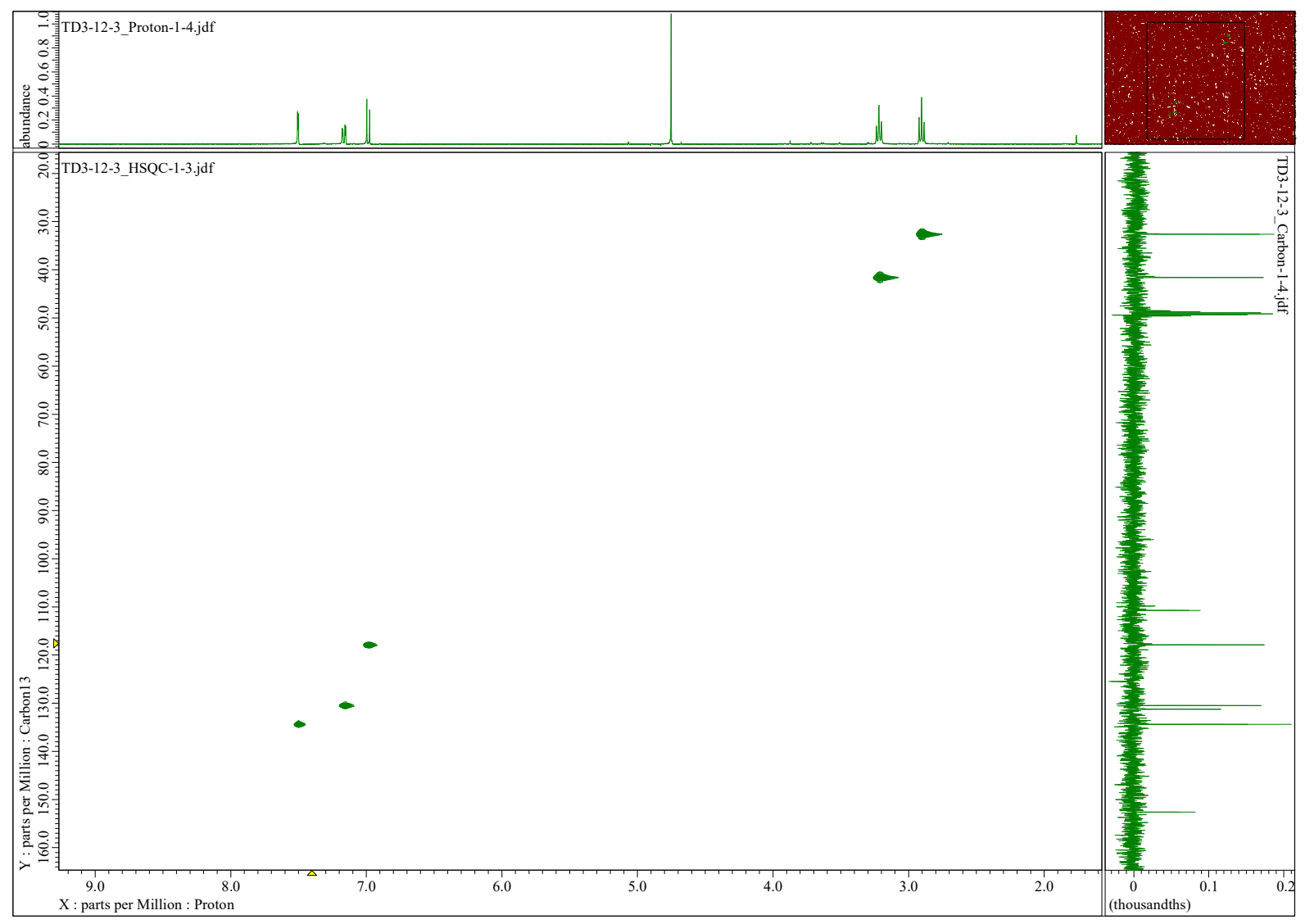

Figure S145. HSQC spectrum of 3-bromotyramine (17) in $\mathrm{D}_{2} \mathrm{O}$ with $10 \mu \mathrm{L} \mathrm{CD} \mathrm{CD}_{3} \mathrm{OD}$.

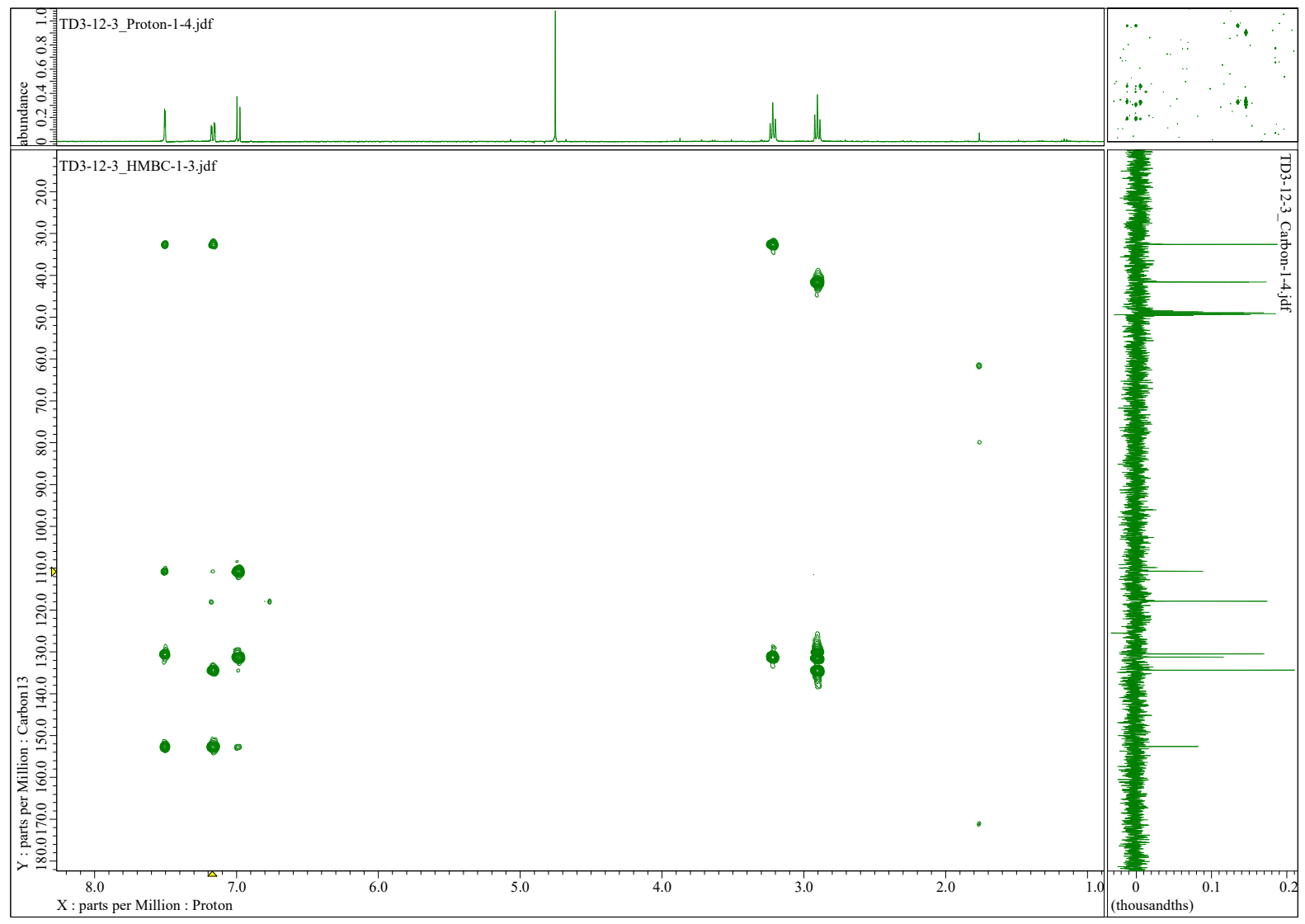

Figure S146. HMBC spectrum of 3-bromotyramine (17) in $\mathrm{D}_{2} \mathrm{O}$ with $10 \mu \mathrm{L} \mathrm{CD}{ }_{3} \mathrm{OD}$. 


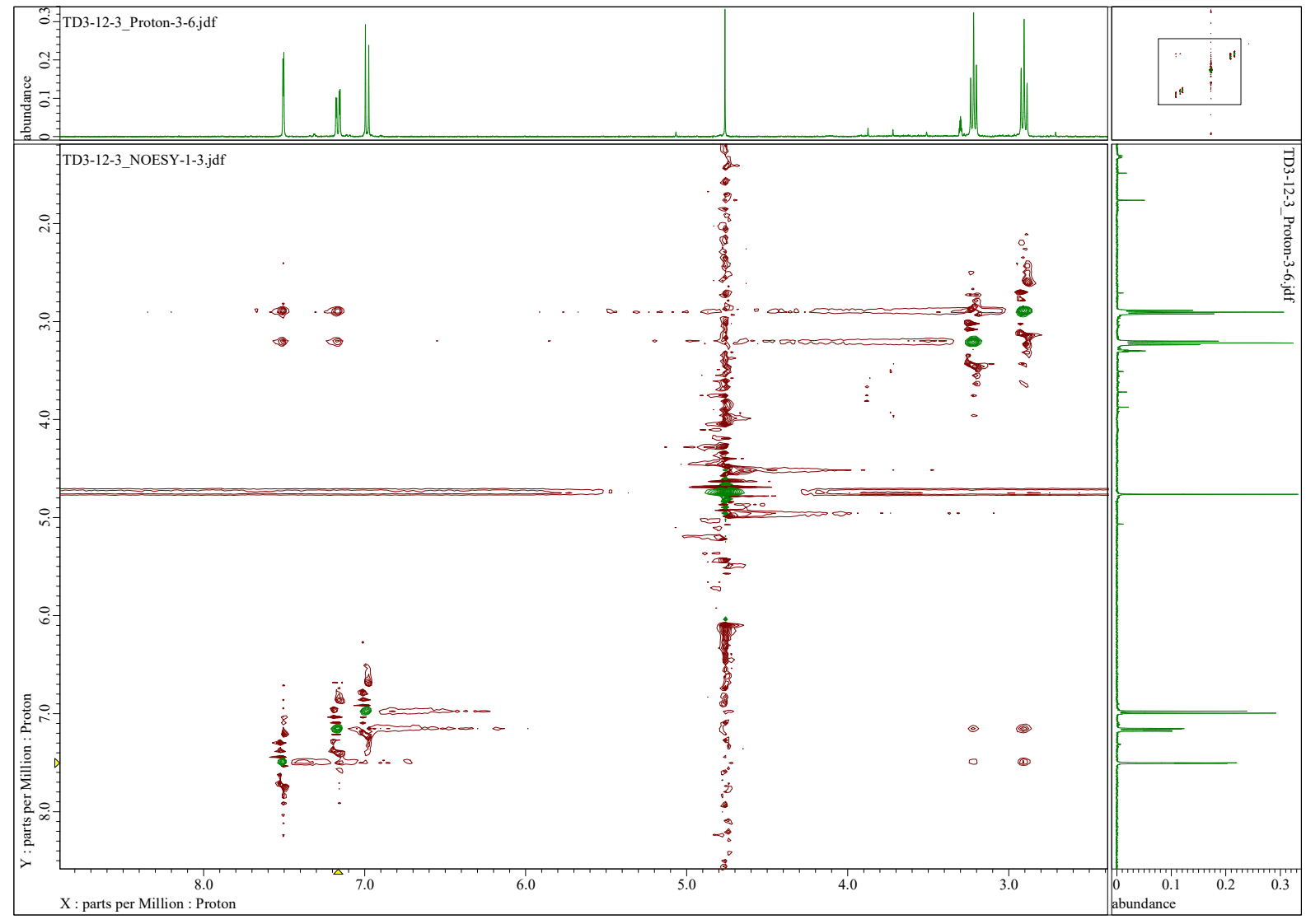

Figure S147. NOESY spectrum of 3-bromotyramine (17) in $\mathrm{D}_{2} \mathrm{O}$ with $10 \mu \mathrm{L} \mathrm{CD}_{3} \mathrm{OD}$ 
3.13. Spectral data and NMR assignments for 3-bromotyramine-O-sulfate (18).

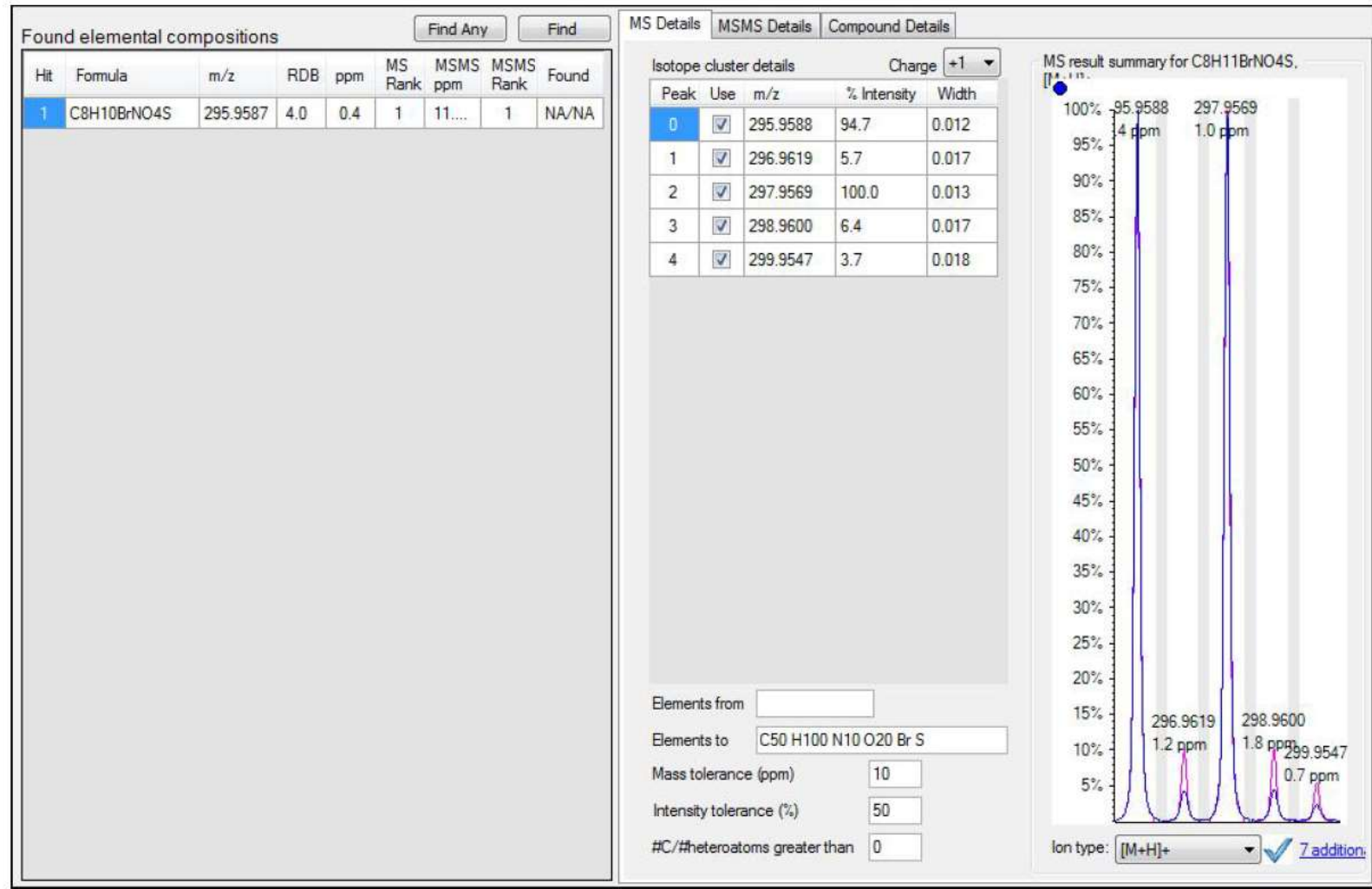

Figure S148. HRESIMS data for 3-bromotyramine- $O$-sulfate (18).

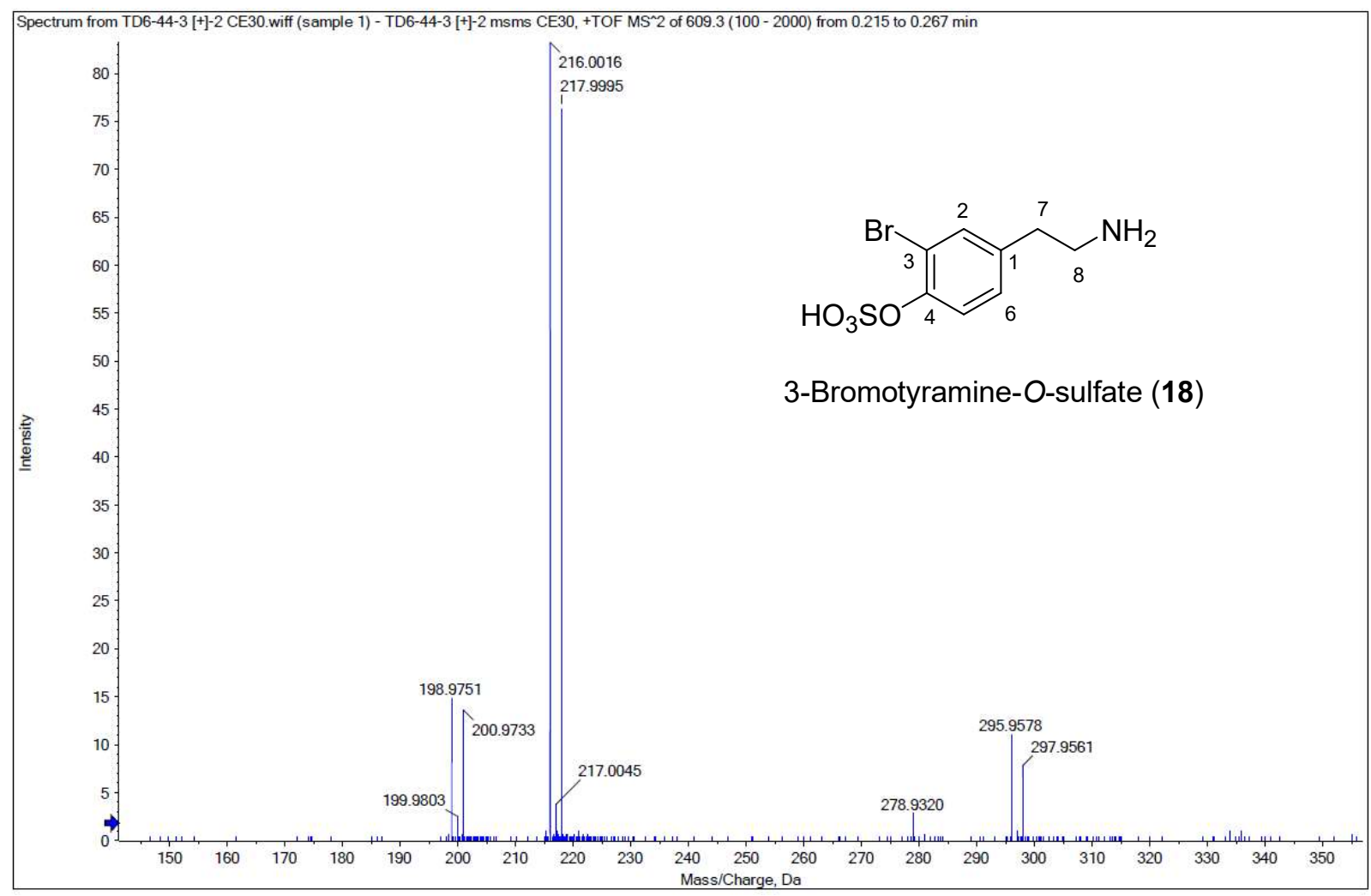

Figure S149. HRESI MS/MS spectrum of 3-bromotyramine- $O$-sulfate (18) in positive mode. 


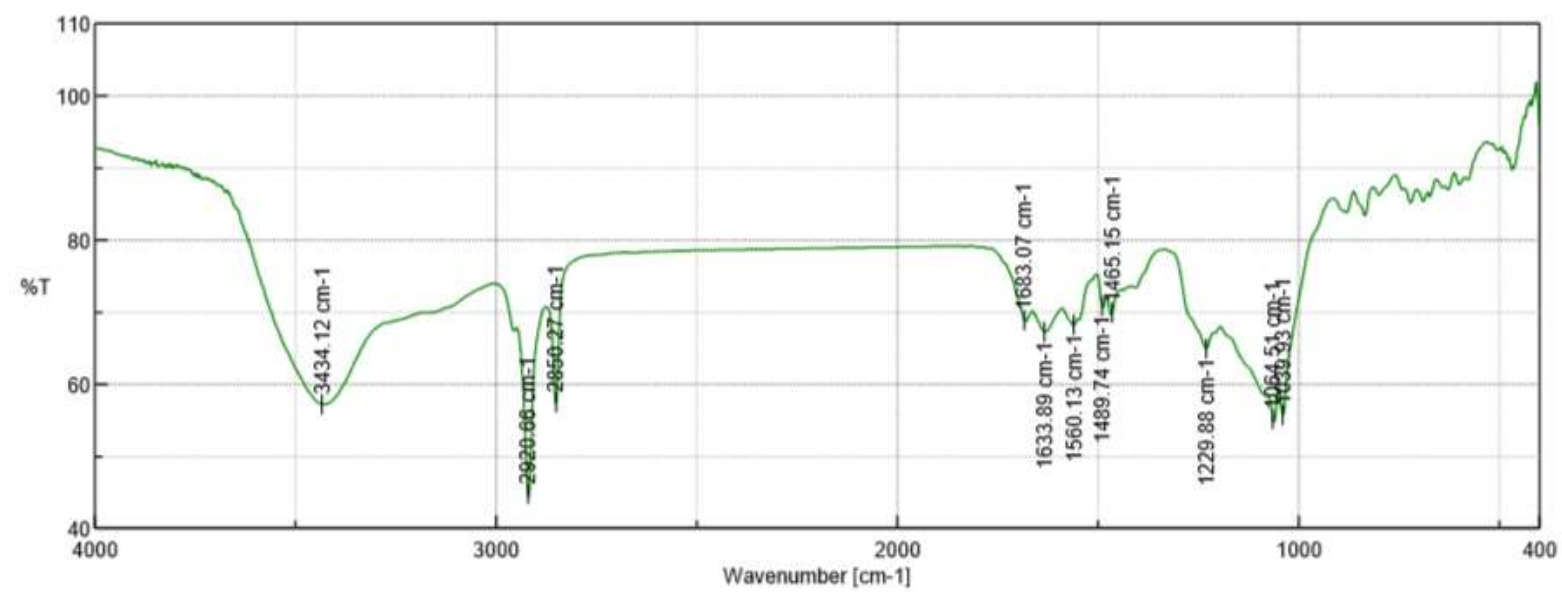

Figure S150. IR spectrum of 3-bromotyramine- $O$-sulfate (18).

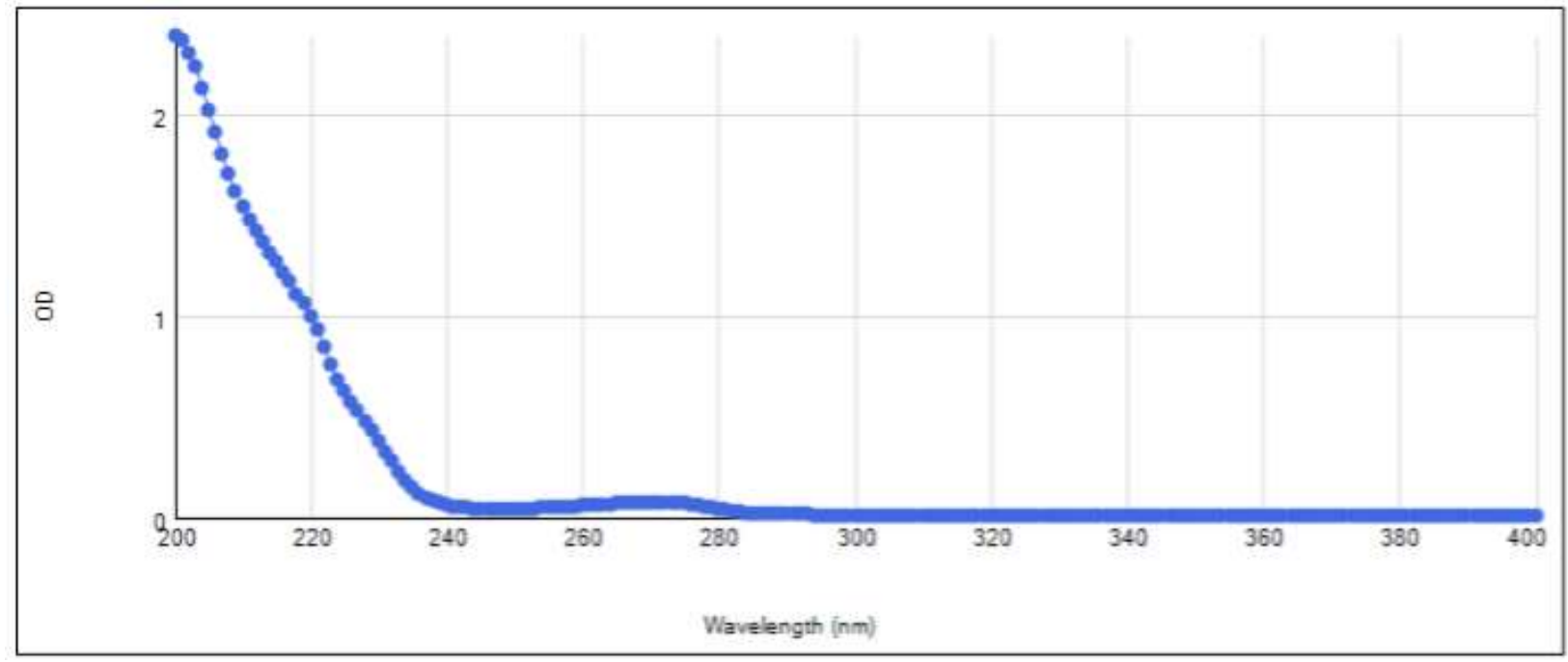

Figure S151. UV spectrum of 3-bromotyramine- $O$-sulfate (18).

Table S20. NMR data $\left({ }^{1} \mathrm{H}: 400 \mathrm{MHz},{ }^{13} \mathrm{C}\right.$ : $\left.100 \mathrm{MHz}\right)$ for 3-bromotyramine- $O$-sulfate (18).

\begin{tabular}{cccccc}
$\# \mathrm{C}$ & $\delta_{\mathrm{C}}$ & $\delta_{\mathrm{H}}$ mult. $(J$ in Hz$)$ & COSY & HMBC & NOESY \\
\hline 1 & $133.1, \mathrm{C}$ & & & & \\
2 & $132.6, \mathrm{CH}$ & $7.64, \mathrm{~d}(2.3)$ & $5(\mathrm{w})$ & $3,4,6,7$ & $5,7,8$ \\
3 & $113.9, \mathrm{C}$ & & & & \\
4 & $149.5, \mathrm{C}$ & & & & \\
5 & $121.3, \mathrm{CH}$ & $7.55, \mathrm{~d}(8.7)$ & 6 & $1,3,4$ & 6 \\
6 & $128.5, \mathrm{CH}$ & $7.17, \mathrm{dd}(8.2,2.3)$ & $2(\mathrm{w}), 5$ & $2,3(\mathrm{vw}), 4,7$ & $5,7,8(\mathrm{w})$ \\
7 & $31.9, \mathrm{CH}_{2}$ & $2.78, \mathrm{t}(7.6)$ & 8 & $1,6,8$ & $2,6,8,9-\mathrm{NH}_{2}(\mathrm{w})$ \\
8 & $39.8^{a}, \mathrm{CH}_{2}$ & $3.04, \mathrm{t}(7.8)$ & 7 & 1,7 & $2(\mathrm{w}), 6(\mathrm{w}), 7,9$ \\
$9-\mathrm{NH}_{2}$ & & $7.70, \mathrm{brs}$ & & & $7(\mathrm{w}), 8$ \\
\hline
\end{tabular}

Measured at $298 \mathrm{~K}$ in DMSO- $d_{6} \cdot{ }^{a}$ Chemical shift determined from HSQC spectrum. $\mathrm{w}=$ weak signal. 


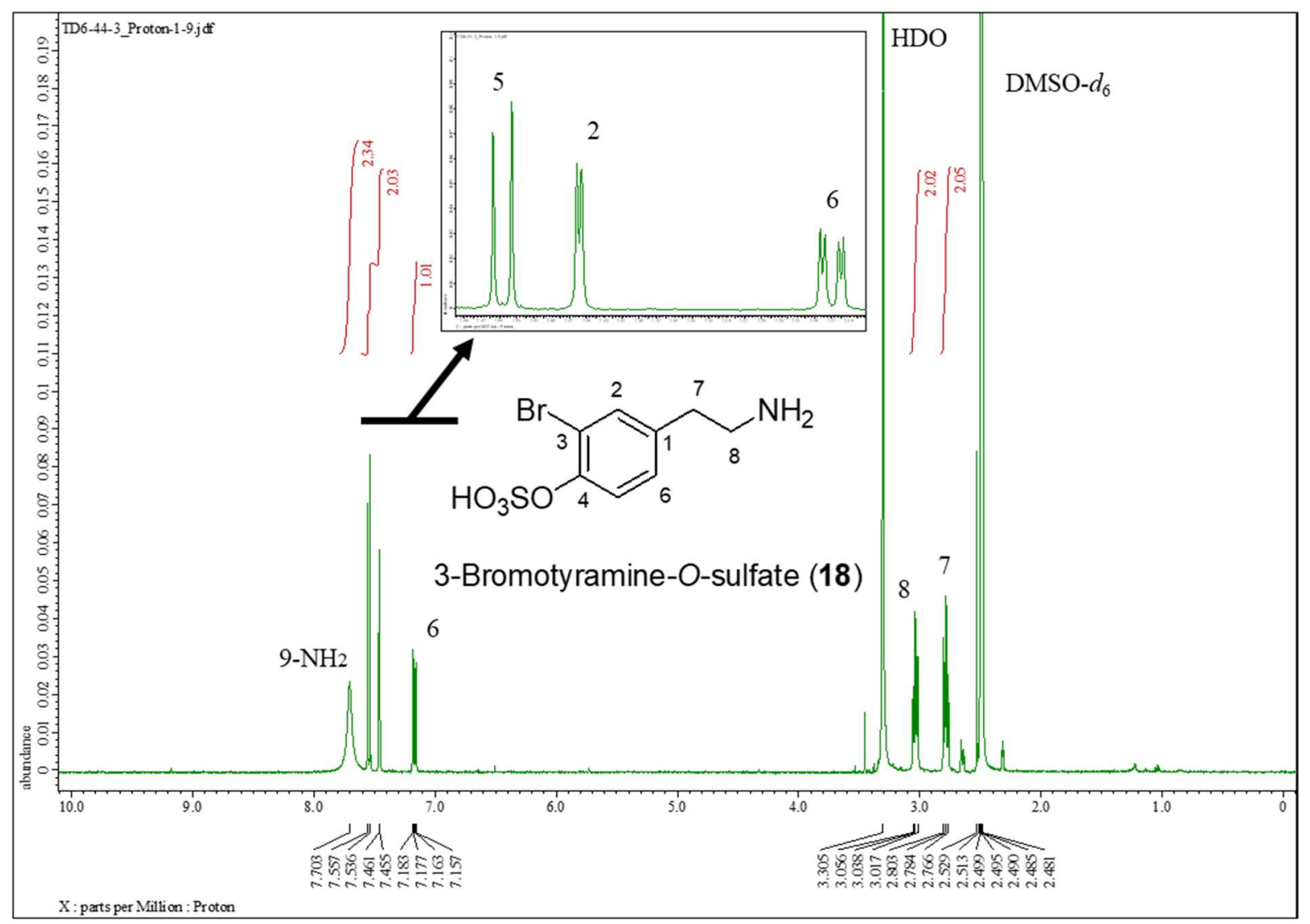

Figure S152. ${ }^{1} \mathrm{H}$ NMR spectrum of 3-bromotyramine- $O$-sulfate (18) in DMSO- $d_{6}(400 \mathrm{MHz})$.

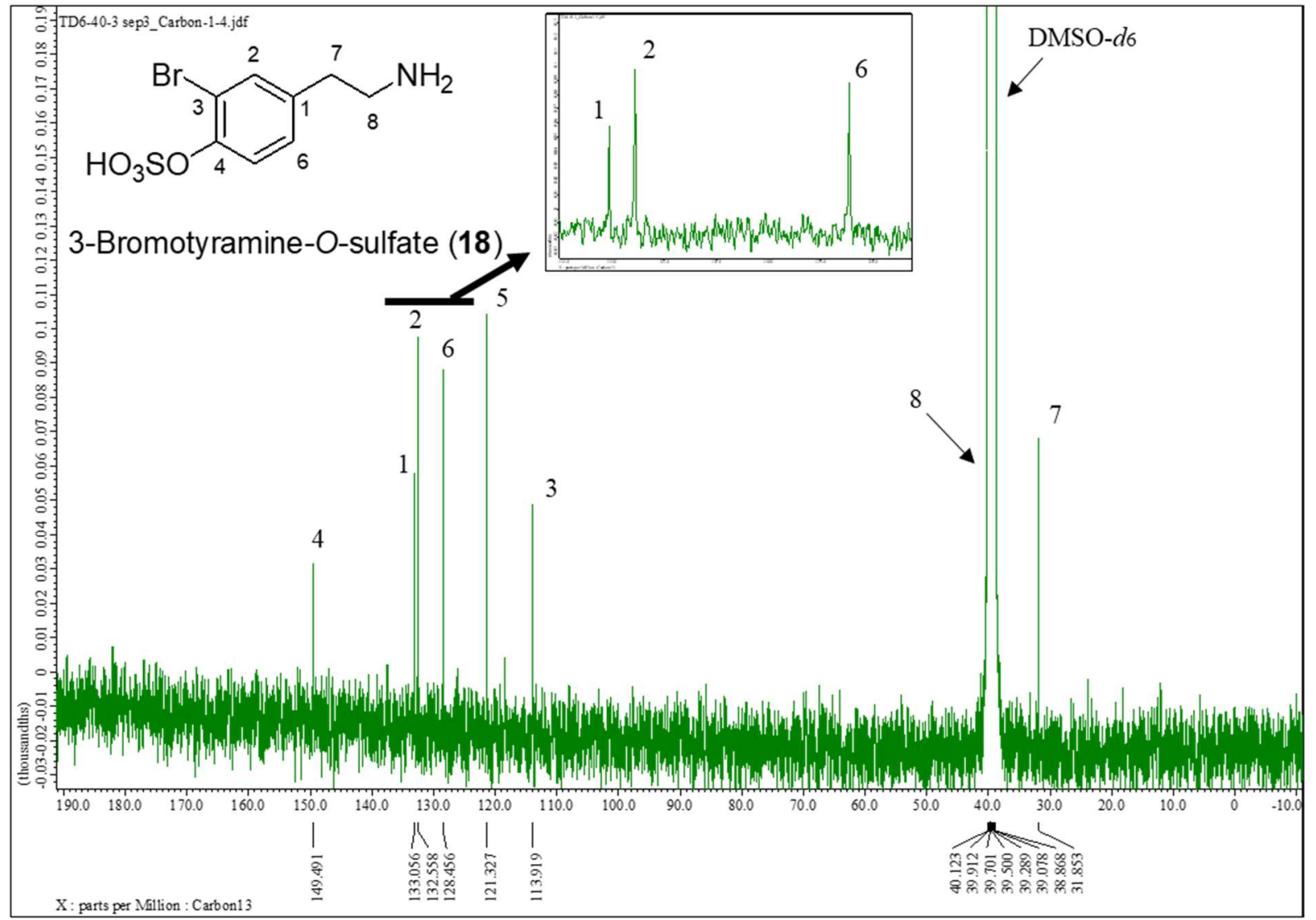

Figure S153. ${ }^{13} \mathrm{C}$ NMR spectrum of 3-bromotyramine- $O$-sulfate (18) in DMSO- $d_{6}(100 \mathrm{MHz})$. 


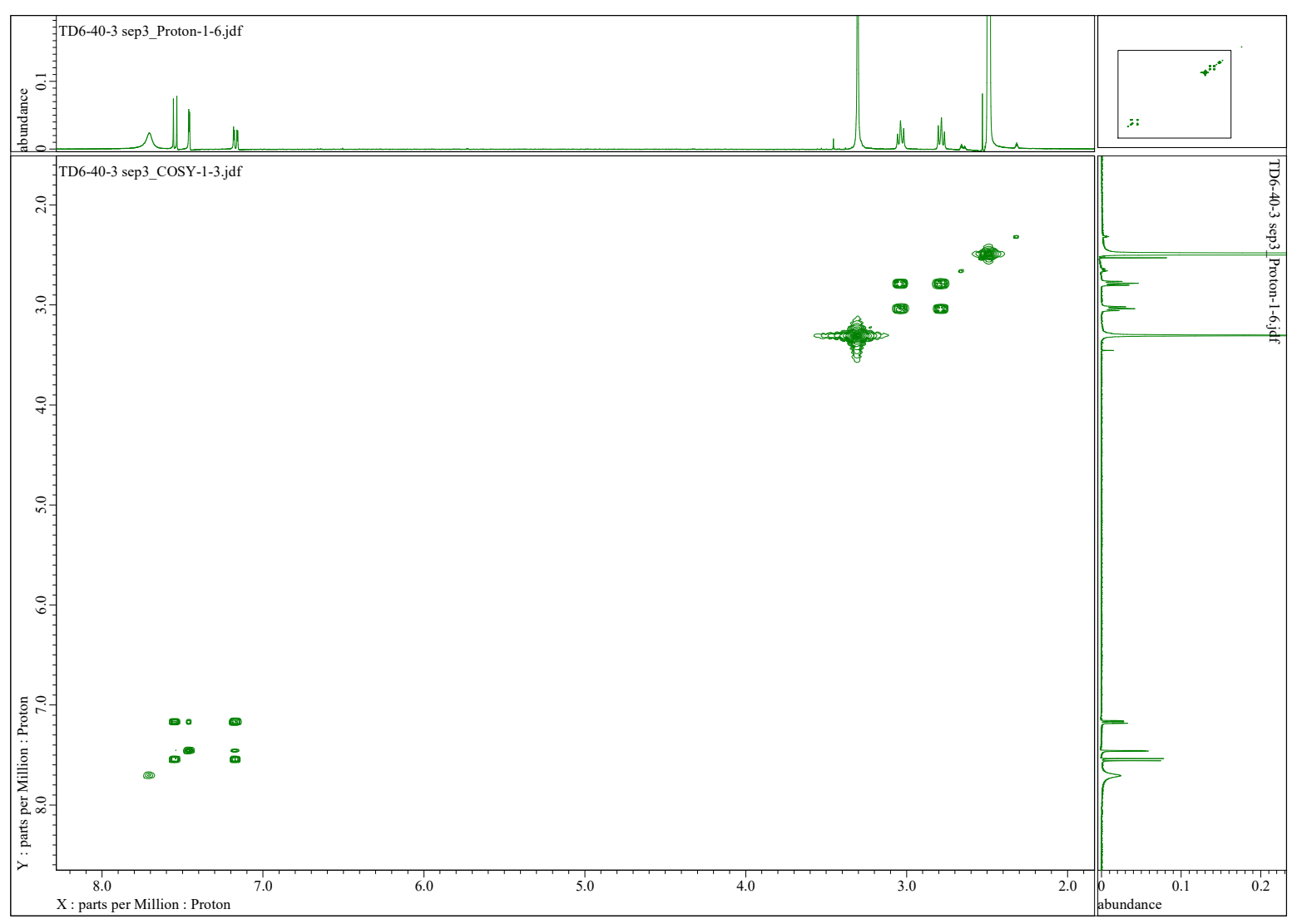

Figure S154. COSY spectrum of 3-bromotyramine- $O$-sulfate (18) in DMSO- $d_{6}$.

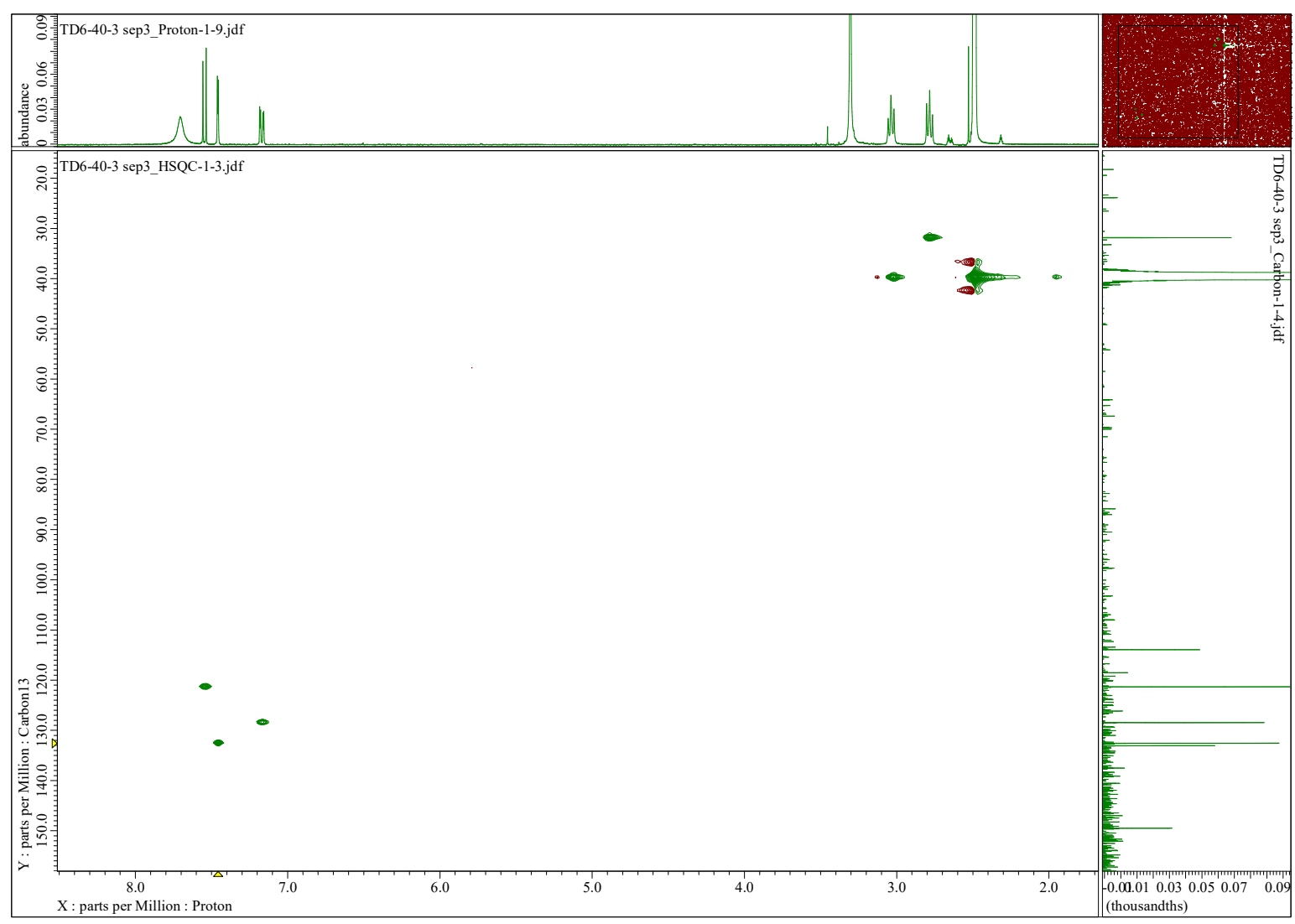

Figure S155. HSQC spectrum of 3-bromotyramine- $O$-sulfate (18) in DMSO- $d_{6}$. 


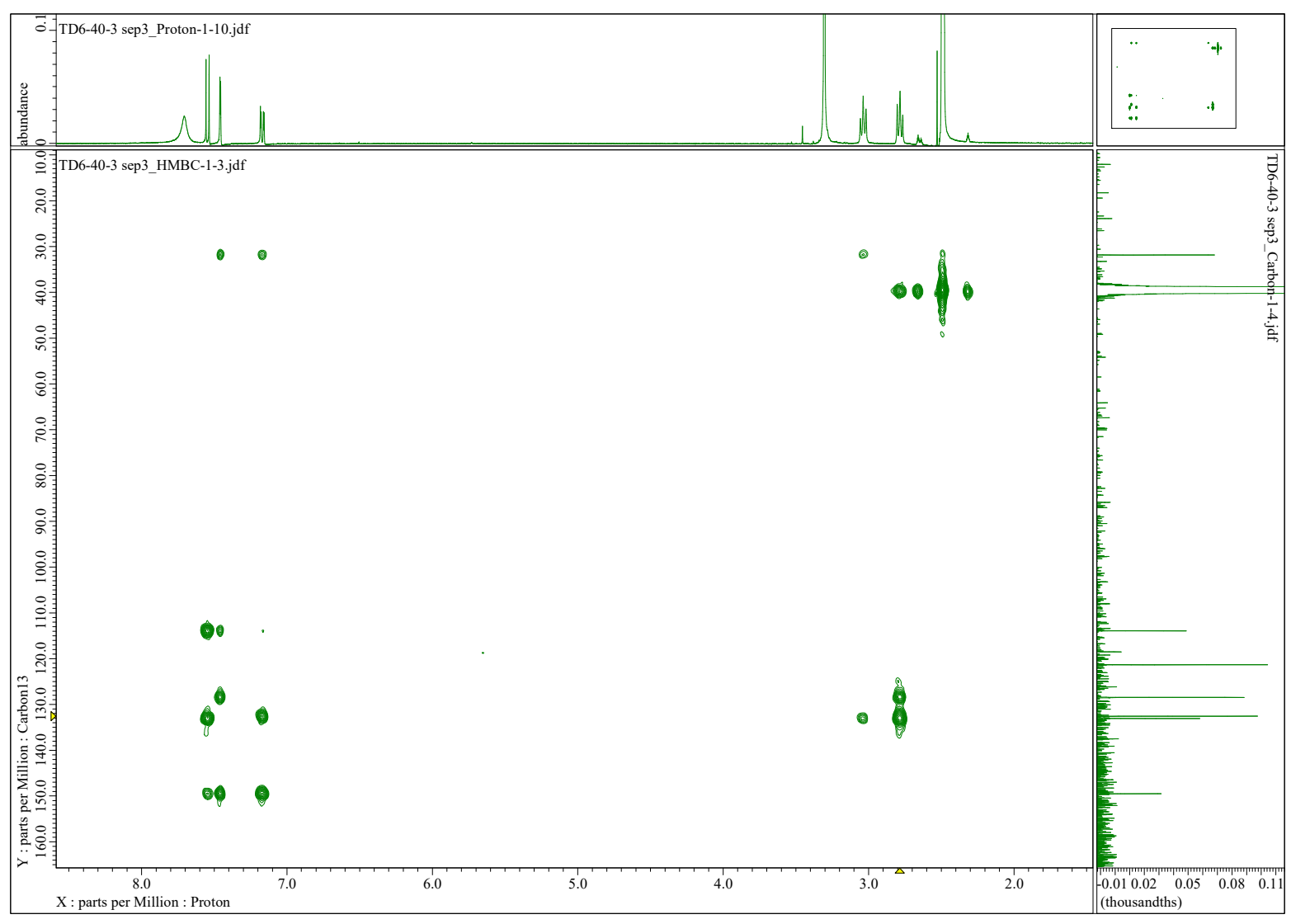

Figure S156. HMBC spectrum of 3-bromotyramine- $O$-sulfate (18) in DMSO- $d_{6}$.

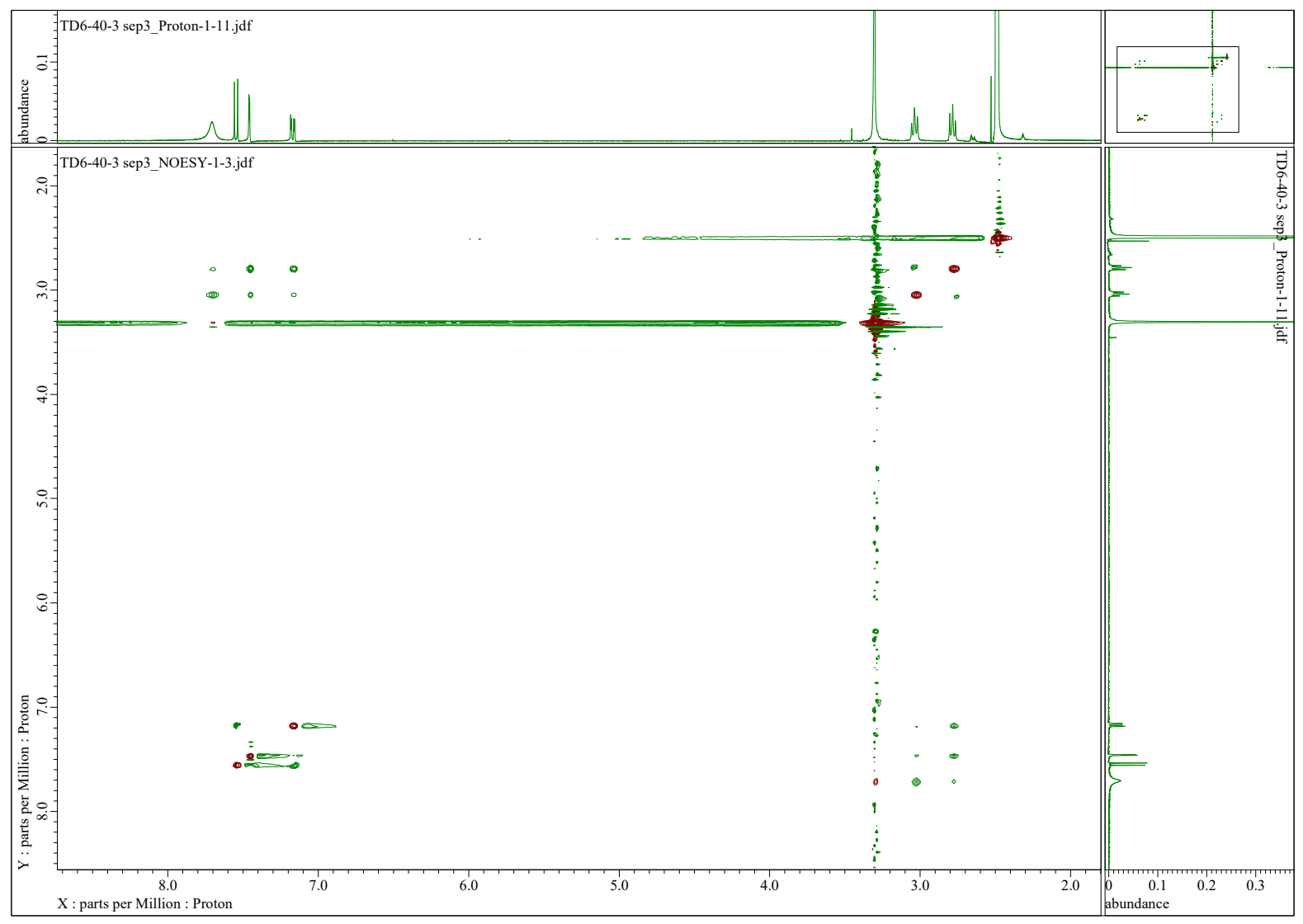

Figure S157. NOESY spectrum of 3-bromotyramine- $O$-sulfate (18) in DMSO- $d_{6}$. 
3.14. Physicochemical properties, spectral data and NMR assignments for tyramine-O-sulfate (19).

Tyramine-O-sulfate (19), white solid: $\mathrm{UV}\left(\mathrm{H}_{2} \mathrm{O}\right) \lambda_{\max }(\log \varepsilon) 208$ (3.75), $262(2.34) \mathrm{nm}$; IR (KBr) $v_{\max } 3448,2924$, $2850,1633,1577,1538,1468,1285,1205,1050 \mathrm{~cm}^{-1} ;{ }^{1} \mathrm{H}$ NMR $\left(\mathrm{D}_{2} \mathrm{O}\right.$ with $10 \mu \mathrm{L}$ DMSO- $\left.d_{6}, 400 \mathrm{MHz}\right)$ and ${ }^{13} \mathrm{C}$ NMR (100 MHz) (Table S21); HRESIMS $m / z 218.0480[\mathrm{M}+\mathrm{H}]^{+}$(calcd for $\mathrm{C}_{8} \mathrm{H}_{12} \mathrm{NO}_{4} \mathrm{~S}, \mathrm{~m} / z$ 218.0482), m/z 216.0326 [M-H] $]^{-}$(calcd for $\mathrm{C}_{8} \mathrm{H}_{10} \mathrm{NO}_{4} \mathrm{~S}, m / z$ 216.0336); HRESI MSMS m/z $201.0212\left[\mathrm{M}+\mathrm{H}-\mathrm{NH}_{3}\right]^{+}$(calcd for $\mathrm{C}_{8} \mathrm{H}_{9} \mathrm{O}_{4} \mathrm{~S}$ ), $m / z$ $136.0763\left[\mathrm{M}-\mathrm{H}-\mathrm{SO}_{3}\right]^{-}\left(\right.$calcd for $\left.\mathrm{C}_{8} \mathrm{H}_{10} \mathrm{NO}\right)$.

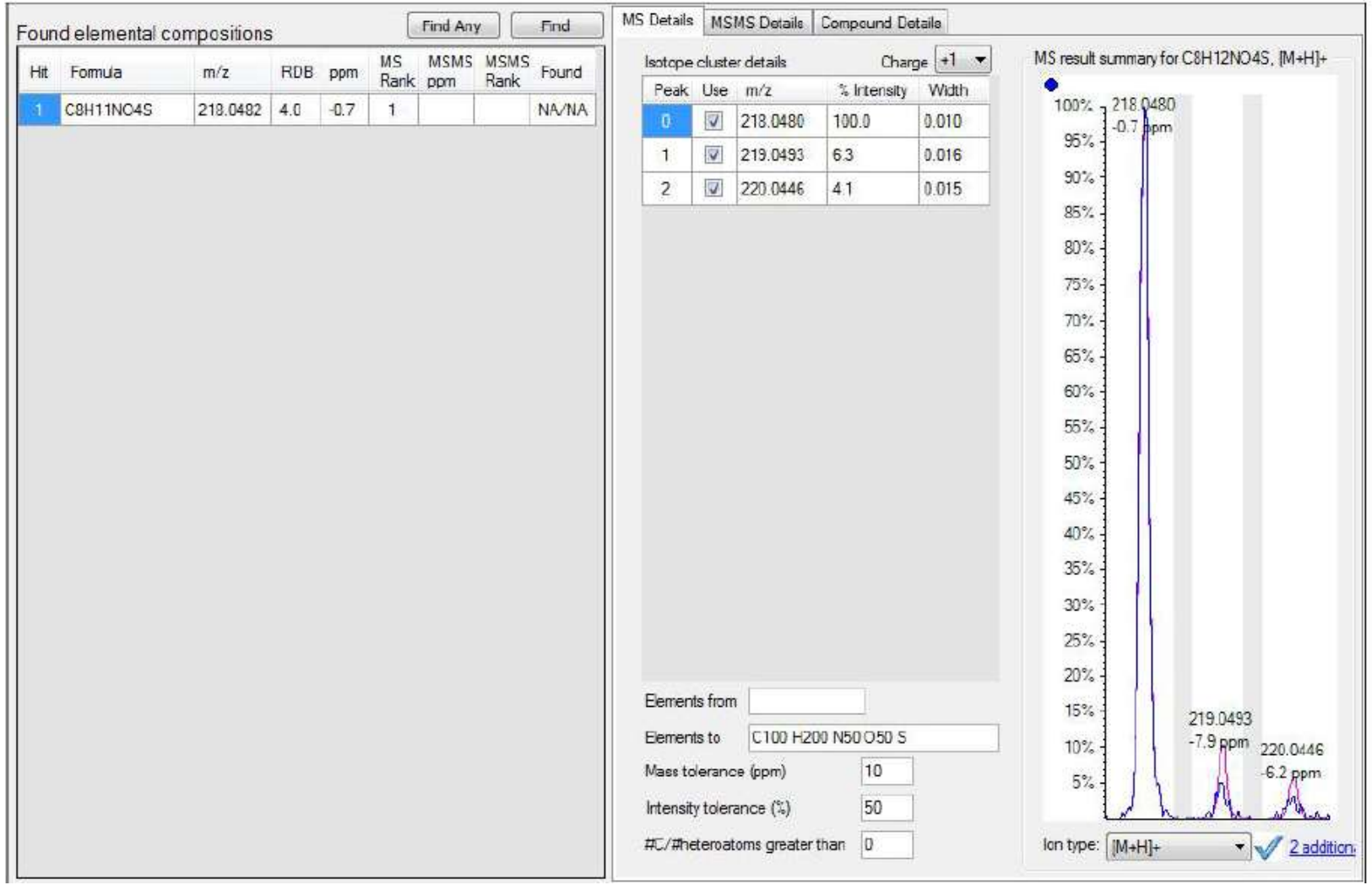

Figure S158. HRESIMS data of tyramine- $O$-sulfate (19) in positive mode. 


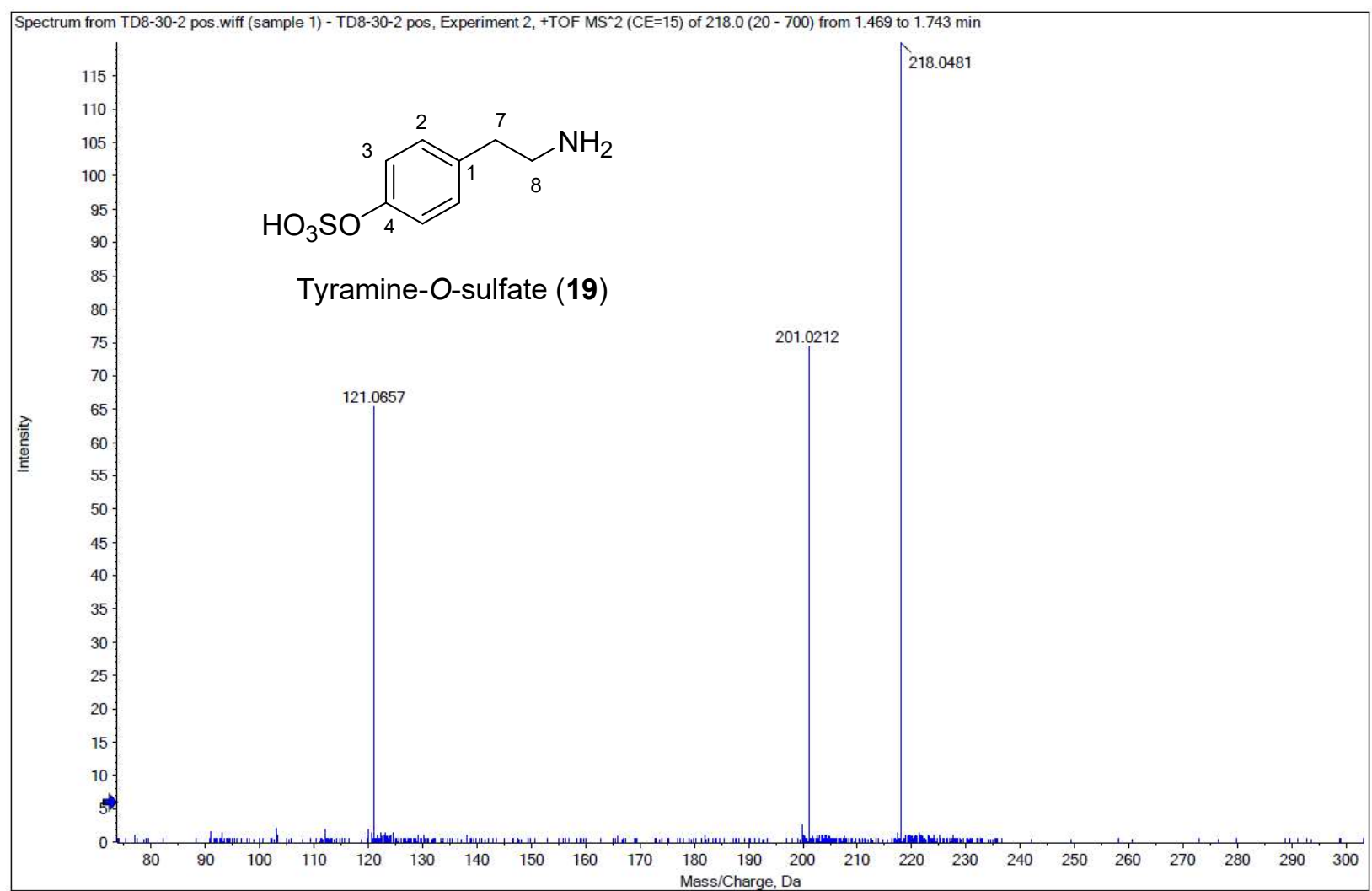

Figure S159. HRESI MSMS spectrum of tyramine- $O$-sulfate (19) in positive mode.

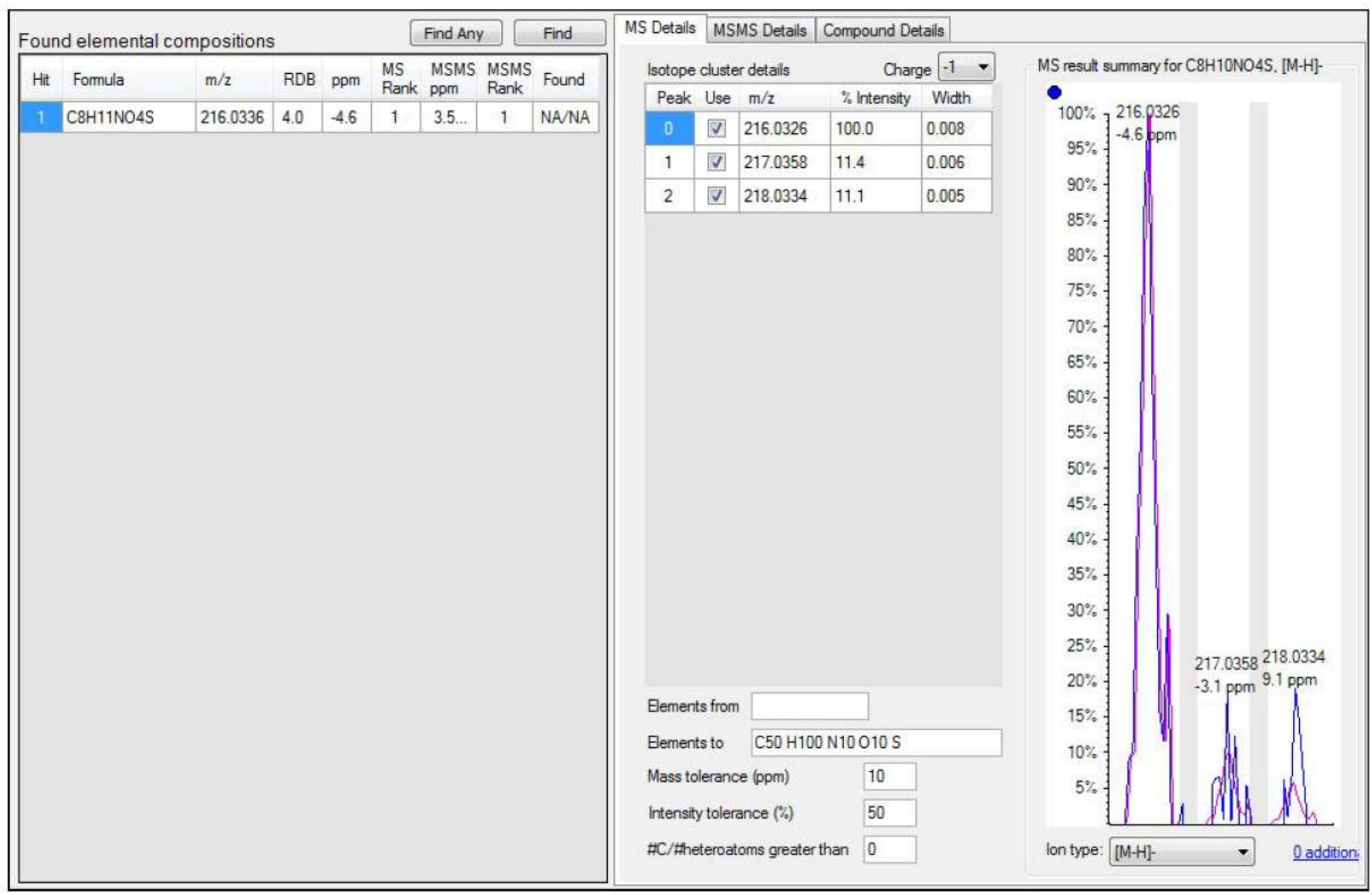

Figure S160. HRESIMS data of tyramine- $O$-sulfate (19) in negative mode. 


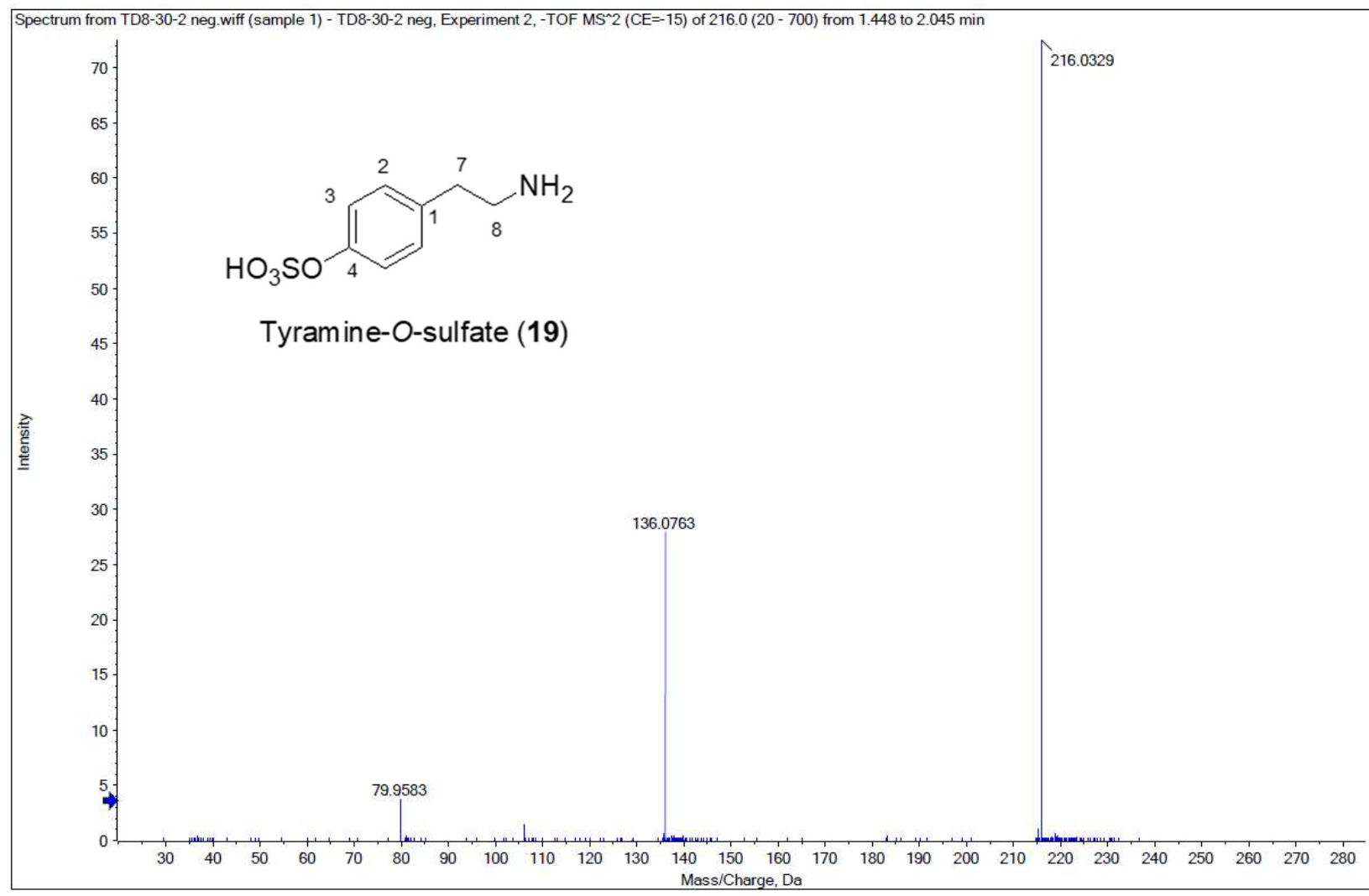

Figure S161. HRESI MSMS spectrum of tyramine- $O$-sulfate (19) in negative mode.

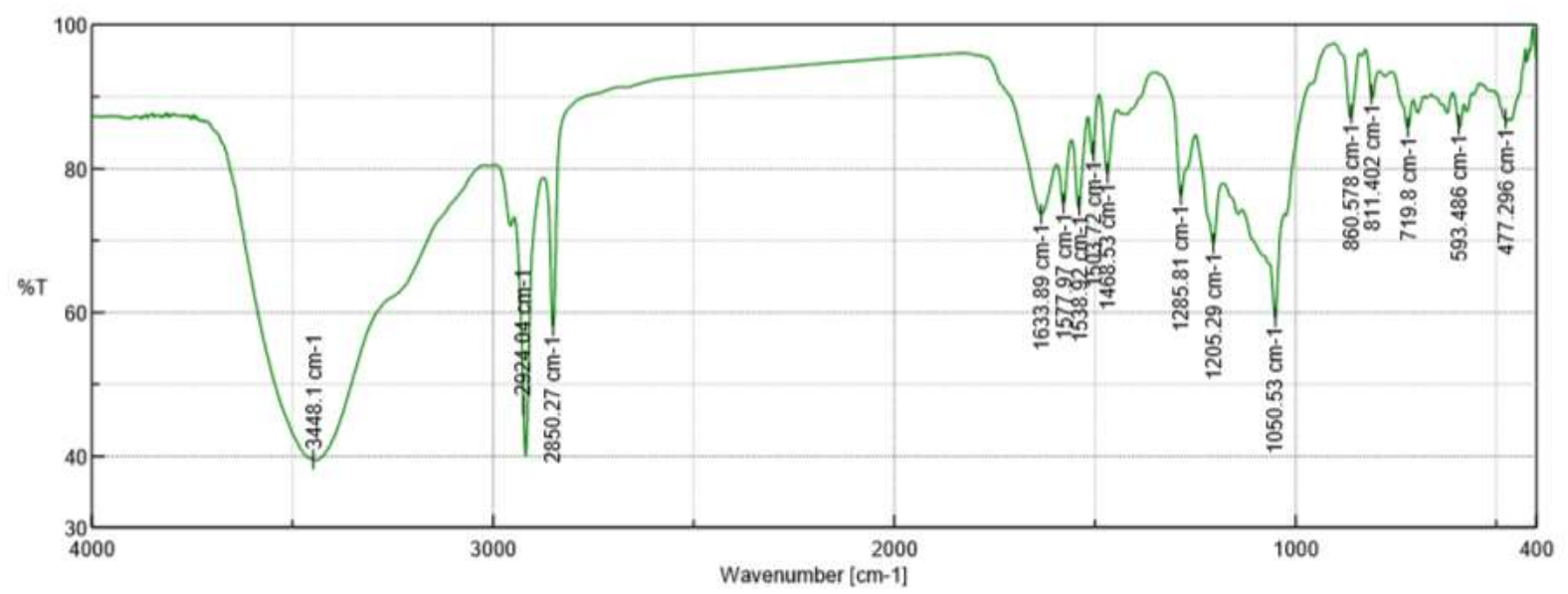

Figure S162. IR spectrum of tyramine- $O$-sulfate (19). 


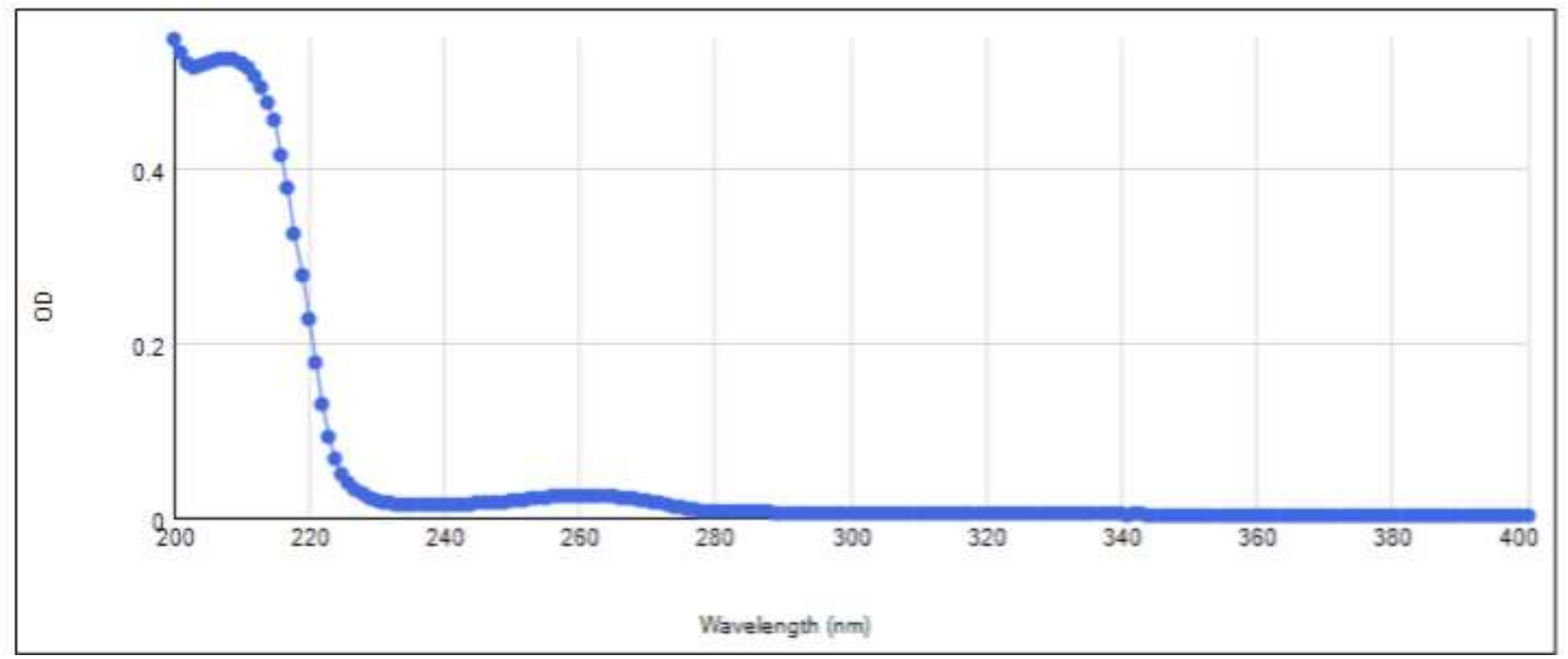

Figure S163. UV spectrum of tyramine- $O$-sulfate (19).

Table S21. NMR data ( $\left.{ }^{1} \mathrm{H}: 400 \mathrm{MHz},{ }^{13} \mathrm{C}: 100 \mathrm{MHz}\right)$ for tyramine- $O$-sulfate (19).

\begin{tabular}{cccccc}
$\# \mathrm{C}$ & $\delta_{\mathrm{C}}$ & $\delta_{\mathrm{H}}$ mult. $(\mathrm{J}$ in $\mathrm{Hz})$ & $\mathrm{COSY}$ & HMBC & NOESY \\
\hline 1 & $136.1, \mathrm{C}$ & & & & \\
2 & $131.8, \mathrm{CH}$ & $7.17, \mathrm{dt}(8.7,2.3)^{a}$ & 3 & $2,4,5$ & 5,6 \\
3 & $123.6, \mathrm{CH}$ & $7.11, \mathrm{dt}(8.7,2.3)^{a}$ & 2 & 1,3 & \\
4 & $151.9, \mathrm{C}$ & & & & \\
5 & $33.8, \mathrm{CH}_{2}$ & $2.82, \mathrm{t}(7.1)$ & 6 & $1,2,6$ & 2,6 \\
6 & $42.1, \mathrm{CH}_{2}$ & $3.09, \mathrm{t}(7.3)$ & 5 & 1,5 & 2,5 \\
\hline
\end{tabular}

Measured at $298 \mathrm{~K}$ in $\mathrm{D}_{2} \mathrm{O}$ with $10 \mu \mathrm{L}$ DMSO- $d_{6}$ as internal standard $\left(\delta_{\mathrm{H}} 2.49, \delta_{\mathrm{C}}\right.$ $39.5 \mathrm{ppm})$. ${ }^{a}$ Due to second order effect. 


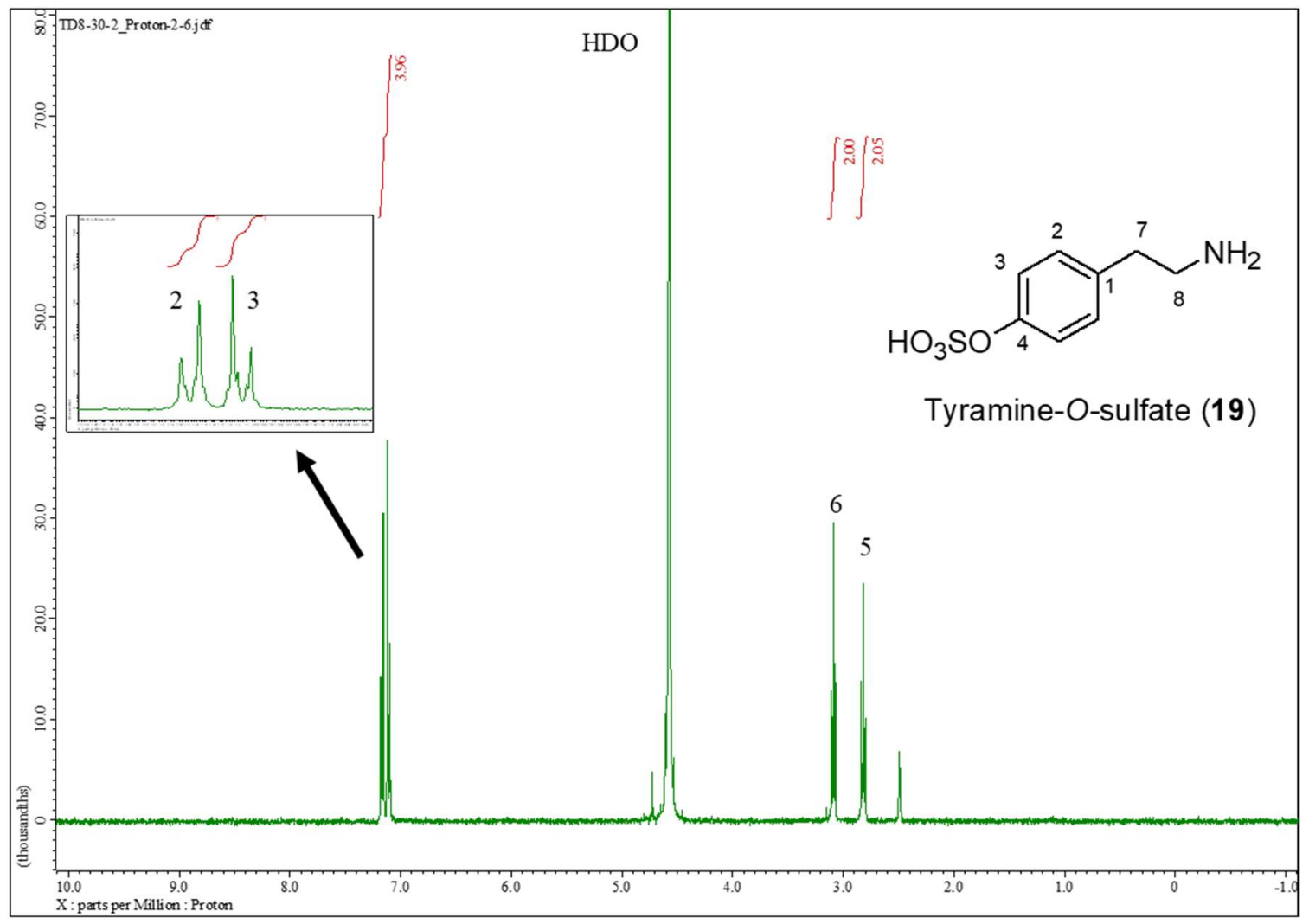

Figure S164. ${ }^{1} \mathrm{H}$ NMR spectrum of tyramine- $O$-sulfate (19) in $\mathrm{D}_{2} \mathrm{O}$ with $10 \mu \mathrm{L}$ DMSO-d 6 (400 MHz). Inset is double triplet like peaks.

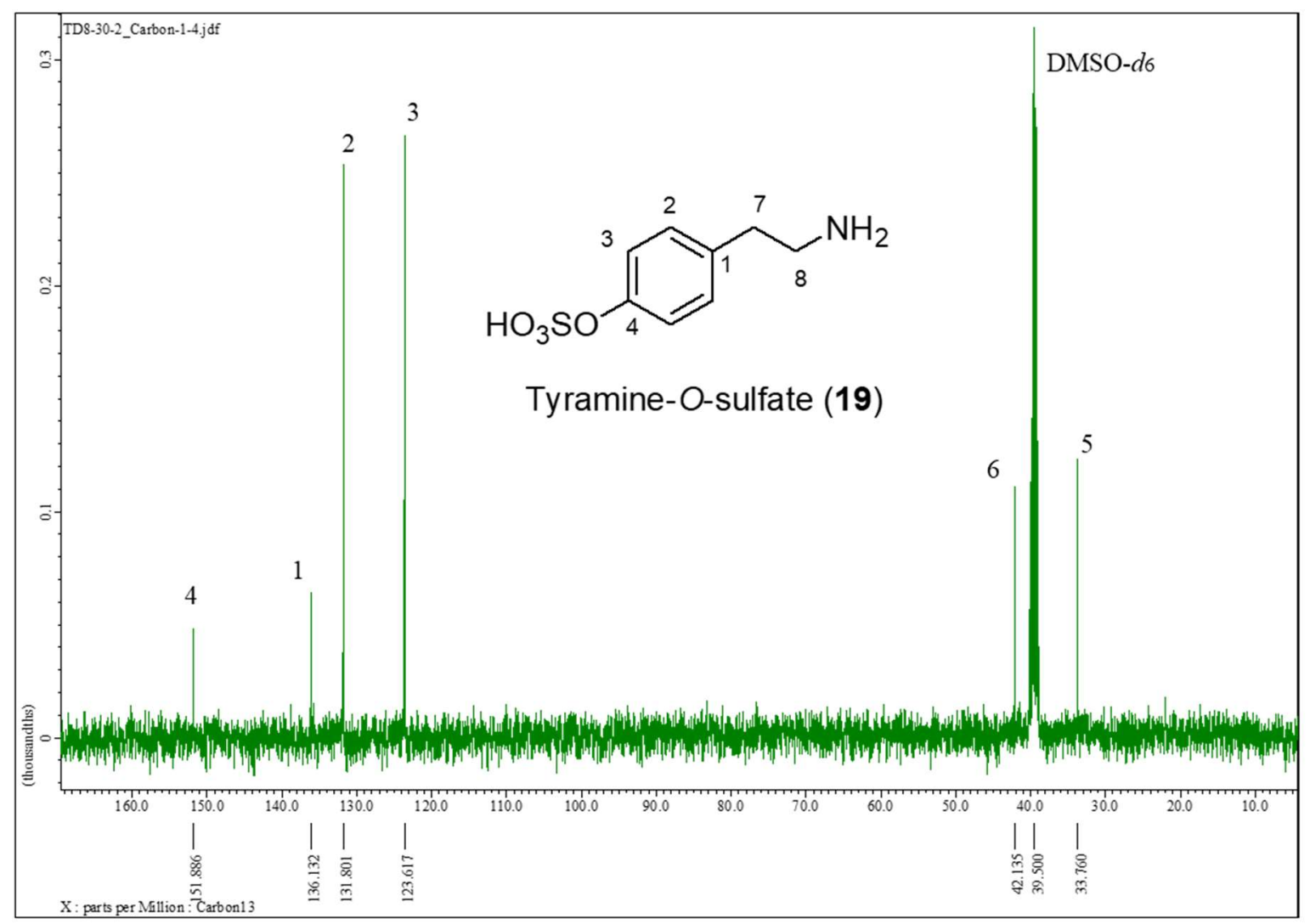

Figure S165. ${ }^{13} \mathrm{C}$ NMR spectrum of tyramine- $O$-sulfate (19) in $\mathrm{D}_{2} \mathrm{O}$ with $10 \mu \mathrm{L}$ DMSO- $d_{6}(100 \mathrm{MHz})$. 


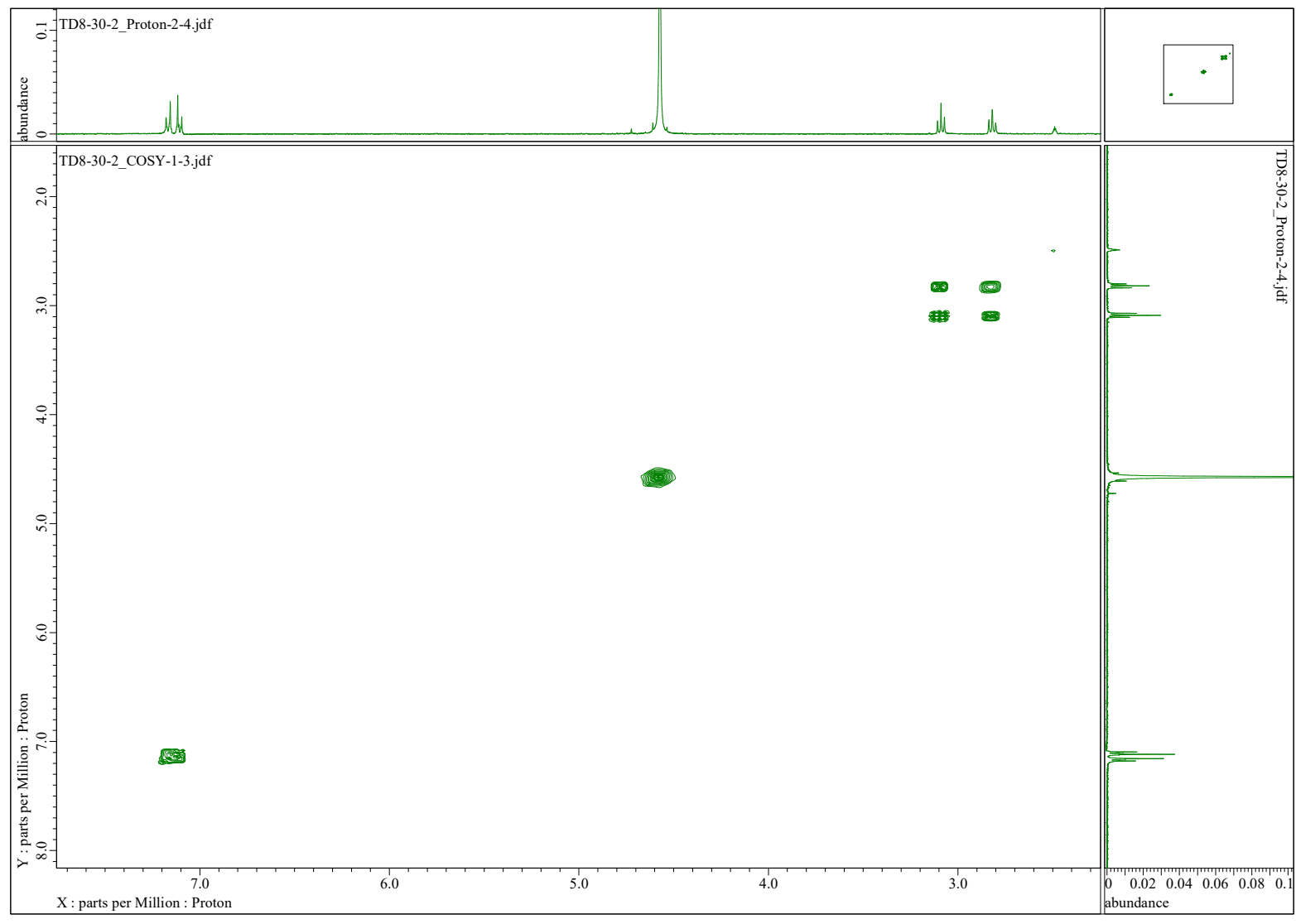

Figure S166. COSY spectrum of tyramine- $O$-sulfate (19) in $\mathrm{D}_{2} \mathrm{O}$ with $10 \mu \mathrm{L}$ DMSO- $d_{6}$.

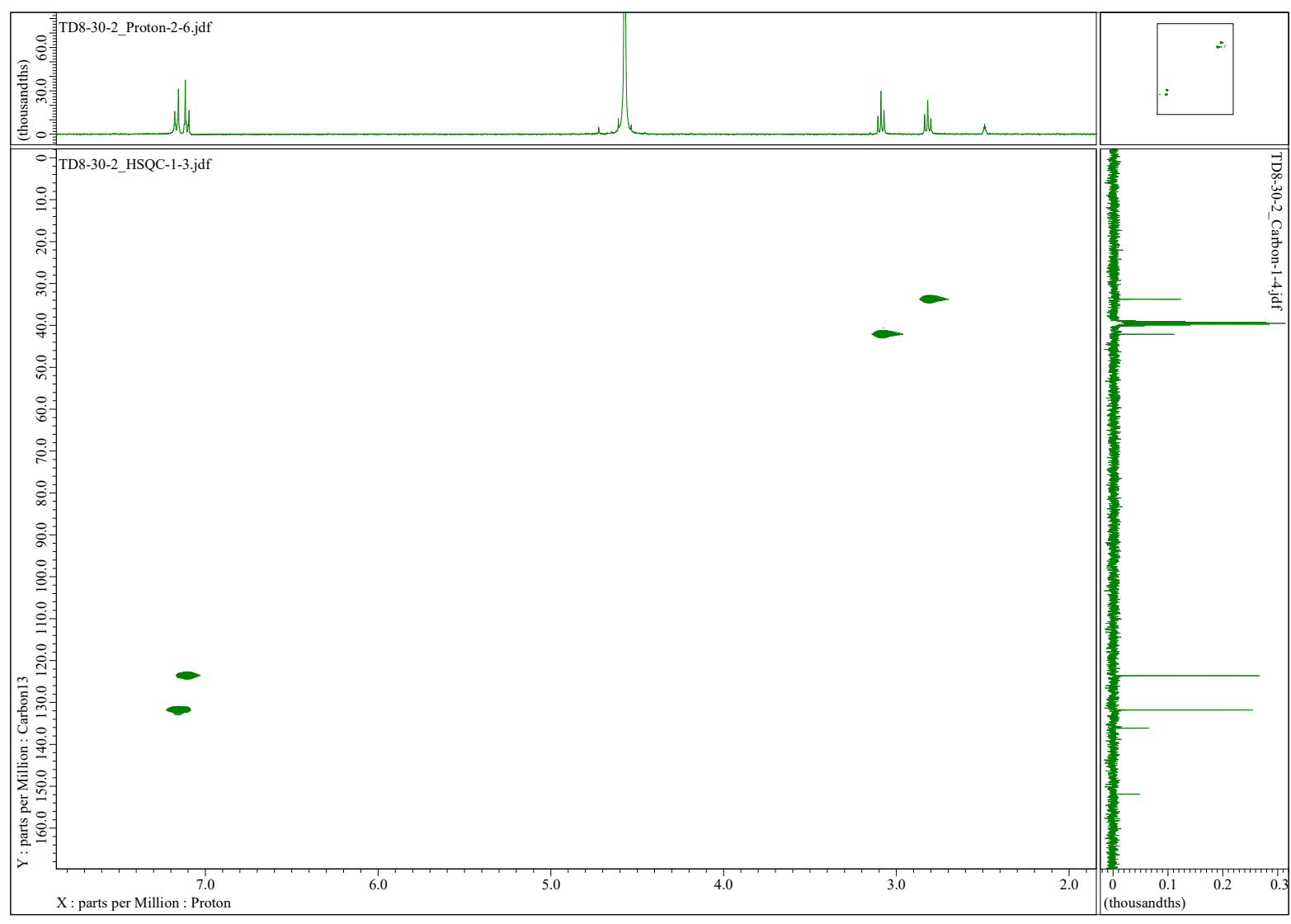

Figure S167. HSQC spectrum of tyramine- $O$-sulfate (19) in $\mathrm{D}_{2} \mathrm{O}$ with $10 \mu \mathrm{L}$ DMSO- $d_{6}$. 


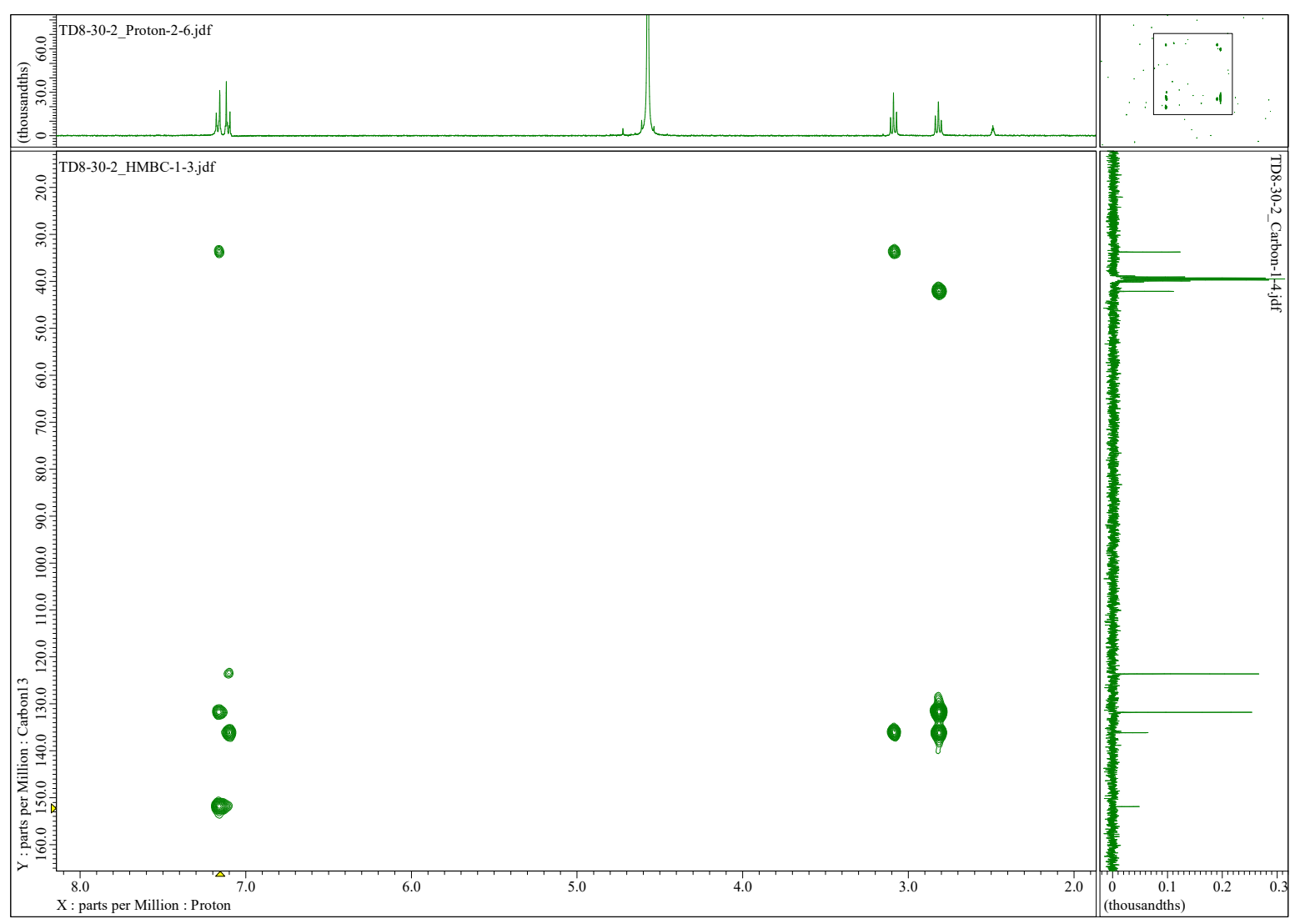

Figure S168. HMBC spectrum of tyramine- $O$-sulfate (19) in $\mathrm{D}_{2} \mathrm{O}$ with $10 \mu \mathrm{L} \mathrm{DMSO}-d_{6}$.

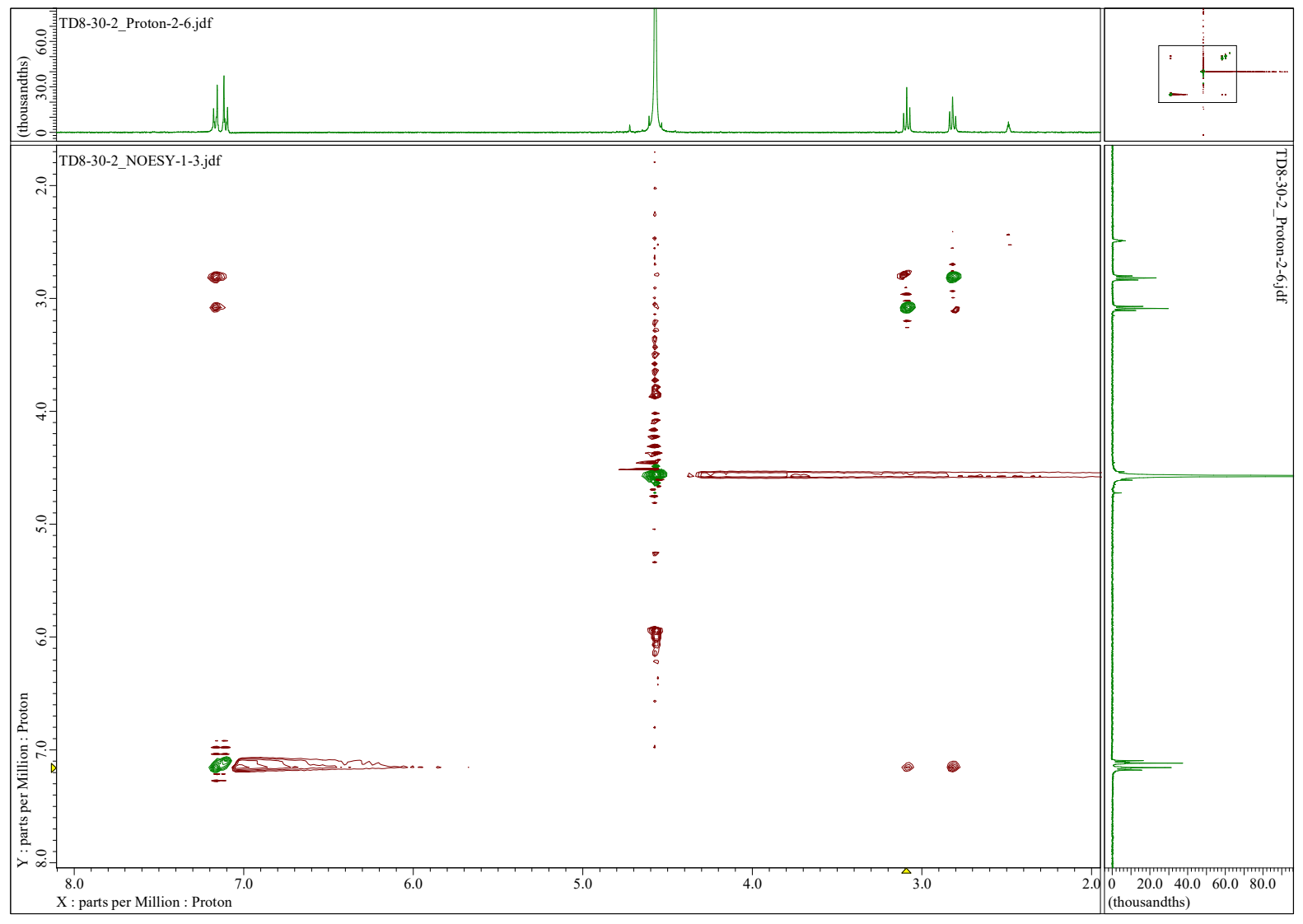

Figure S169. NOESY spectrum of tyramine- $O$-sulfate (19) in $\mathrm{D}_{2} \mathrm{O}$ with $10 \mu \mathrm{L} \mathrm{DMSO}-d_{6}$. 


\section{References}

(1) Schmid, G. H. Can. J. Chem. 1968, 46, 3415-3418.

(2) Guerriero, A.; D'Ambrosio, M.; Pietra, F.; Debitus, C.; Ribes, O. J. Nat. Prod. 1993, 56, 1962-1970.

(3) Tasdemir, D.; Mangalindan, G. C.; Concepcion, G. P.; Harper, M. K.; Ireland, C. M. Chem. Pharm. Bull. 2001, 49, 1628-1630.

(4) Lindsay, B. S.; Battershill, C. N.; Copp, B. R. J. Nat. Prod. 1998, 61, 857-858. 